\title{
ECOLOGICAL MONITORING AND COMPLIANCE PROGRAM CALENDAR YEAR 2005 REPORT
}

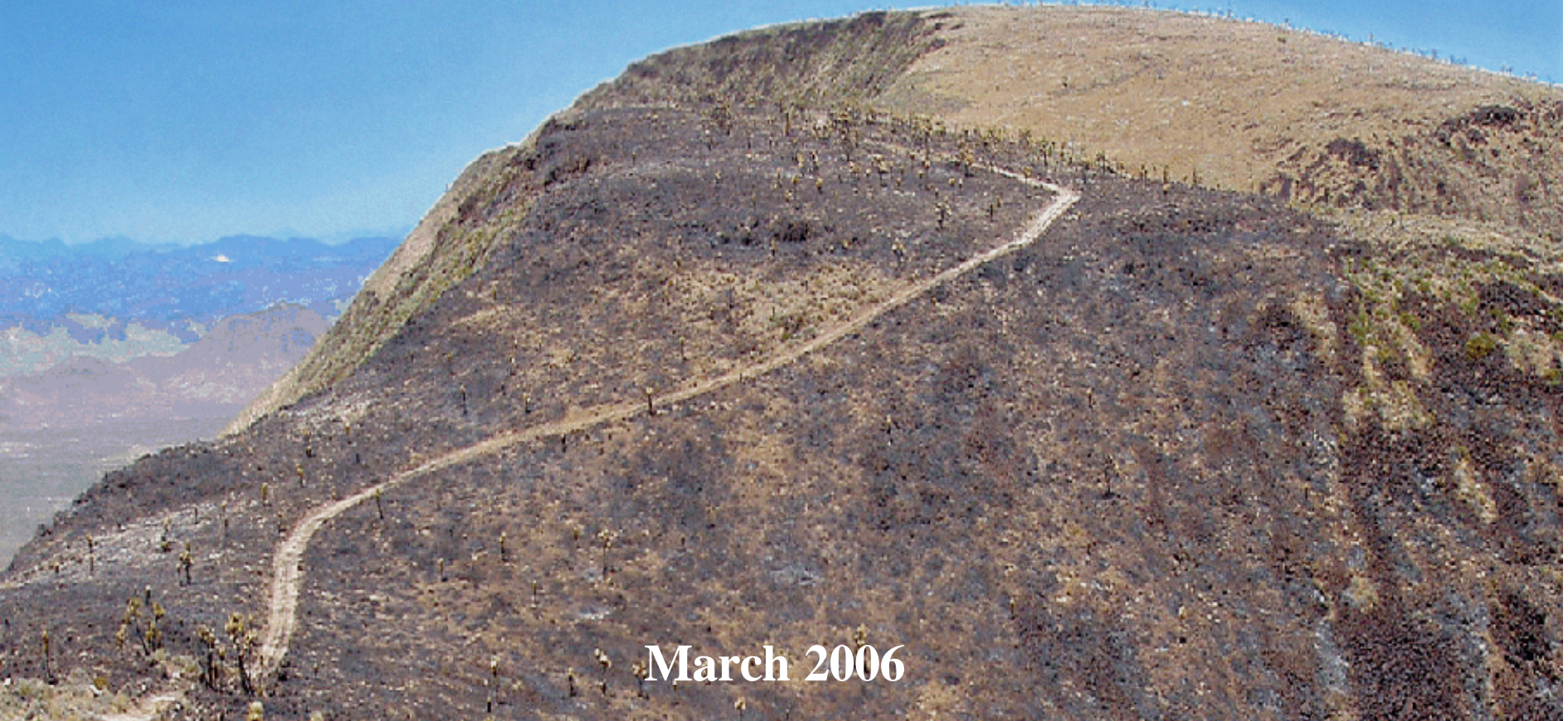

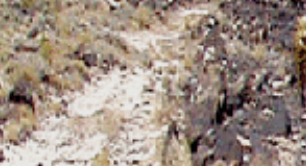

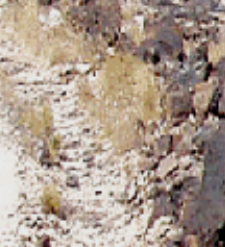

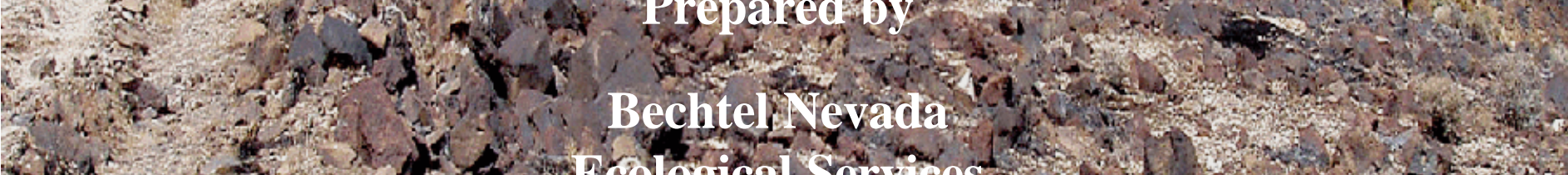

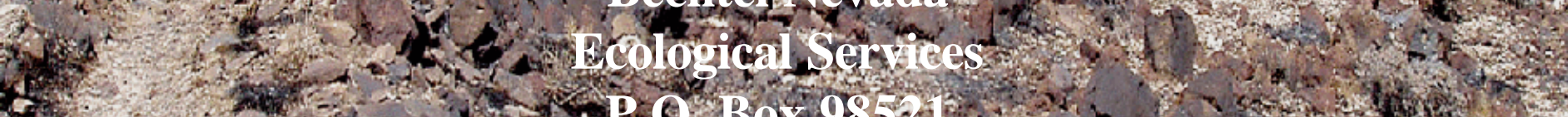

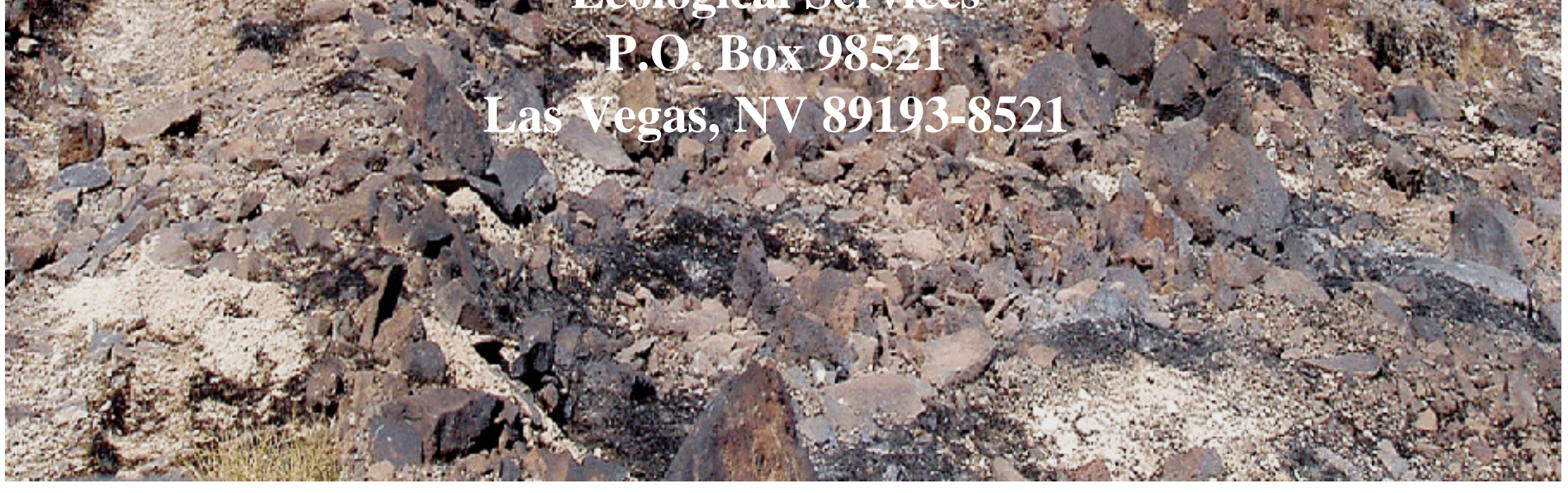




\title{
DISCLAIMER STATEMENT
}

Reference herein to any specific commercial product, process, or service by trade name, trademark, manufacturer, or otherwise, does not necessarily constitute or imply its endorsement, recommendation, or favoring by the United States Government or any agency thereof or its contractors or subcontractors.

\section{AVAILABILITY STATEMENT}

Available for sale to the public from-

\author{
U.S. Department of Commerce \\ National Technical Information Service \\ 5285 Port Royal Road \\ Springfield, VA 22161-0002 \\ Telephone: 800.553.6847 \\ Fax: 703.605.6900 \\ E-mail: orders@ntis.gov \\ Online Ordering: http://www.ntis.gov/ordering.htm
}

Available electronically at http://www.osti.gov/bridge

Available for a processing fee to the U.S. Department of Energy and its contractors, in paper, from-

U.S. Department of Energy

Office of Scientific and Technical Information

P.O. Box 62

Oak Ridge, TN 37831-0062

Telephone: 865.576.8401

Fax: 865.576.5728

E-Mail: reports@adonis.osti.gov 


\title{
ECOLOGICAL MONITORING AND COMPLIANCE PROGRAM CALENDAR YEAR 2005 REPORT
}

\author{
March 2006 \\ WORK PERFORMED UNDER \\ CONTRACT NO. DE-AC08-96NV11718 \\ Prepared for the \\ U.S. Department of Energy \\ National Nuclear Security Administration \\ Nevada Site Office \\ Environment, Safety and Health Division \\ P.O. Box 98518 \\ Las Vegas, NV 89193-8518
}

Prepared by

\section{Bechtel Nevada}

Ecological Services

P.O. Box 98521

Las Vegas, NV 89193-8521 
THIS PAGE IS INTENTIONALLY LEFT BLANK 


\section{CONTENTS}

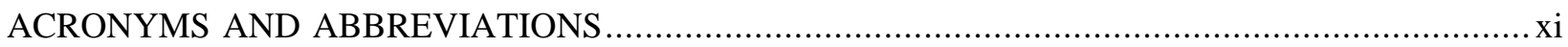

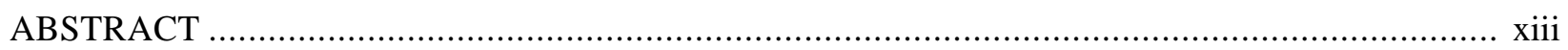

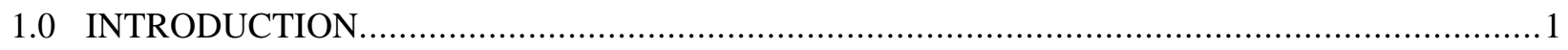

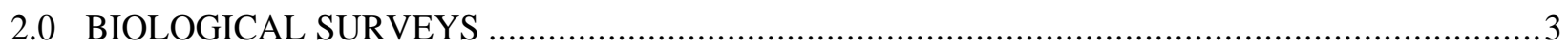

2.1 Sites Surveyed and Sensitive and Protected/Regulated Species Observed ........................... 3

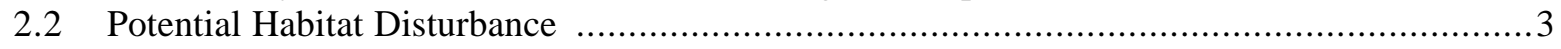

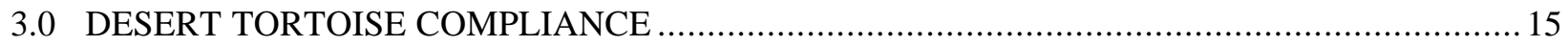

3.1 Project Surveys and Compliance Documentation .................................................. 15

3.2 Habitat Revegetation Plan for Loss of Tortoise Habitat ......................................... 18

3.3 Coordination with Other Wildlife Agencies/Biologists ............................................. 19

3.4 Biological Opinion for Activities at Test Cell C................................................... 19

4.0 ECOSYSTEM MAPPING/DATA MANAGEMENT …..................................................... 21

4.1 Consolidation of Data Tables into a Comprehensive Database …................................. 21

4.2 Sampling of Selected ELUs for Canopy Cover Data ….............................................. 21

4.3 Vegetation Survey for Determining Wildland Fire Hazards ........................................ 22

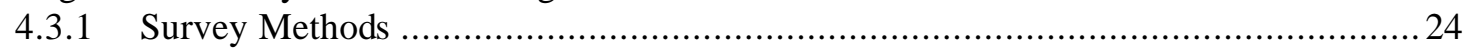

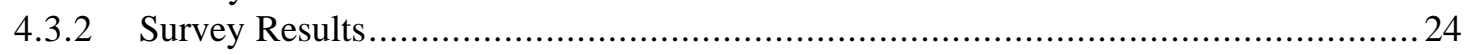

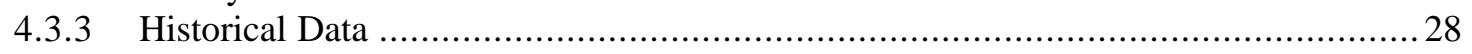

4.4 Coordination with Ecosystem Management Agencies and Scientists ............................. 36

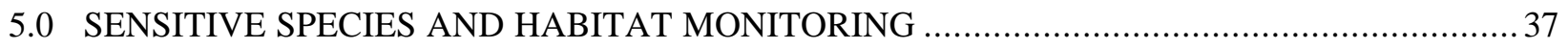

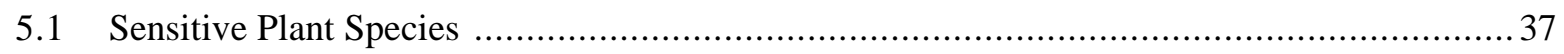

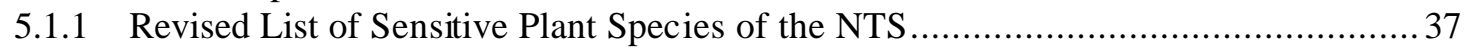

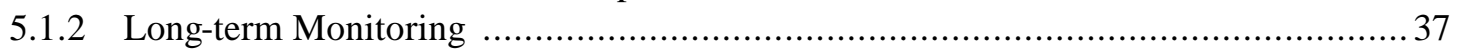

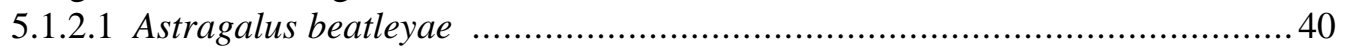

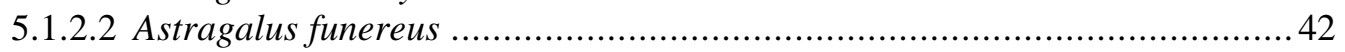

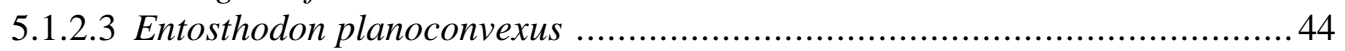

5.1.3 Coordination with Natural Resource Agency Botanists ................................. 45

5.2 Sensitive and Protected/Regulated Animal Species ............................................ 46

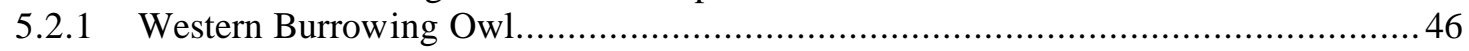

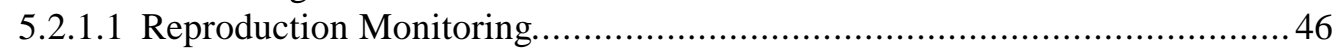

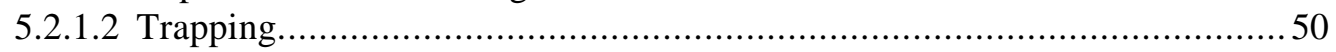

5.2.2 Sensitive and/or Protected/Regulated Bat Species (SPRBS) .............................52

5.2.2.1 Bat Occurrence at Water Sources .................................................. 55

5.2.2.2 Bat Occurrence at Potential Roost Sites ............................................... 55

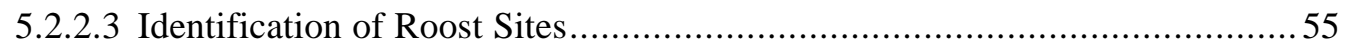

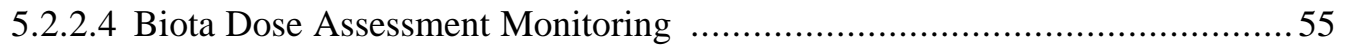

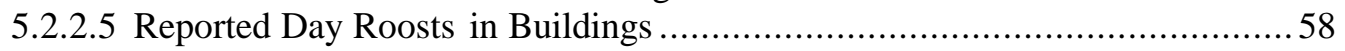

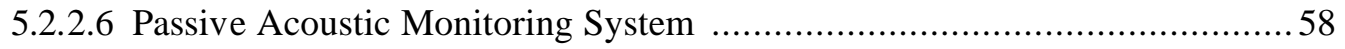

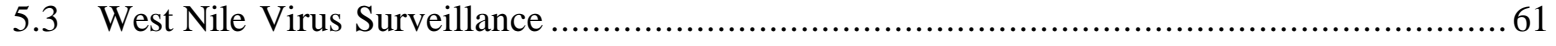

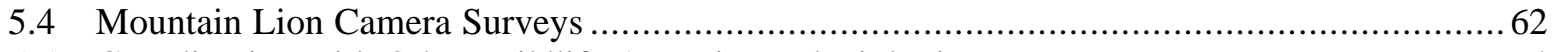

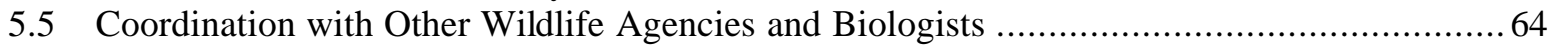




\section{CONTENTS}

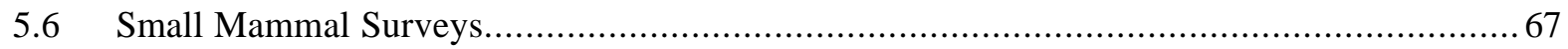

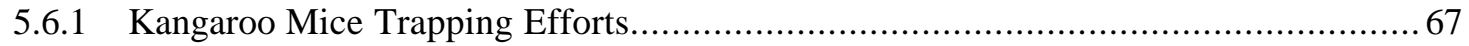

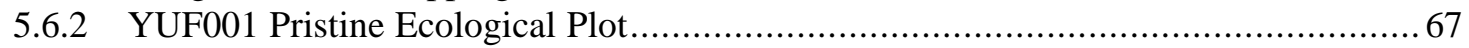

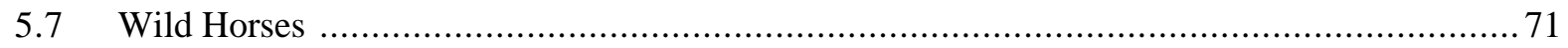

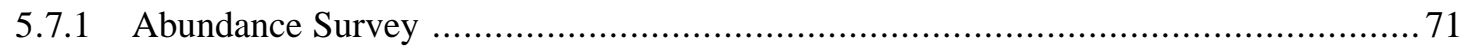

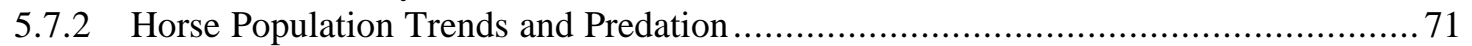

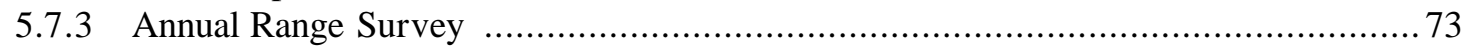

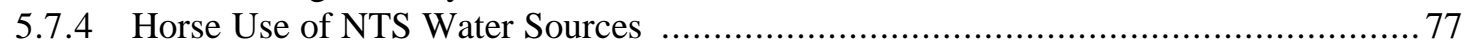

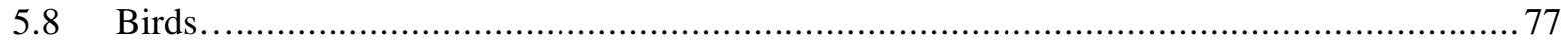

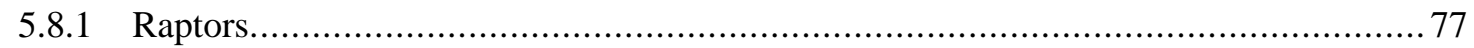

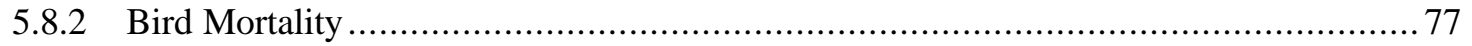

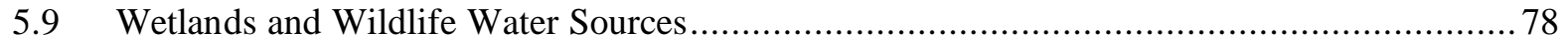

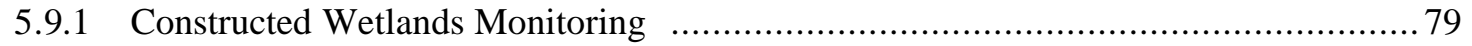

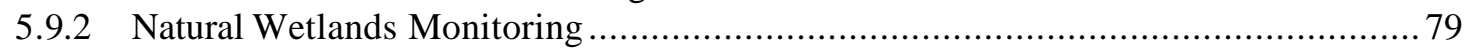

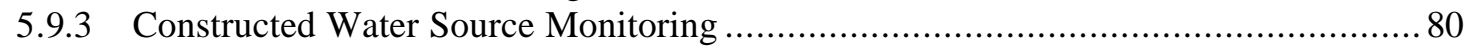

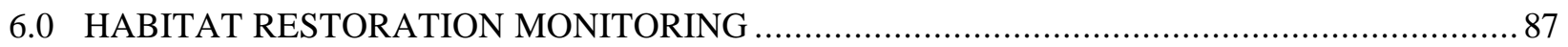

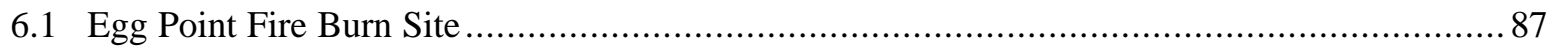

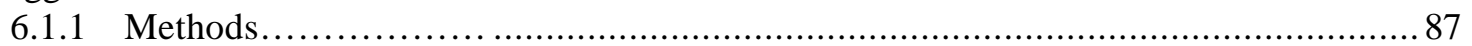

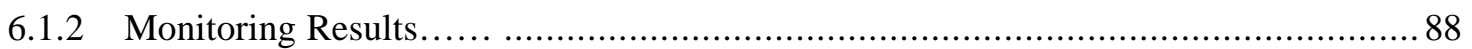

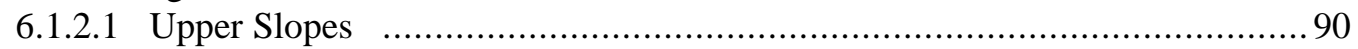

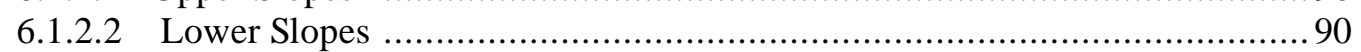

6.2 Habitat Restoration at CAU 110, U-3ax/bl Closure Cover ............................................. 92

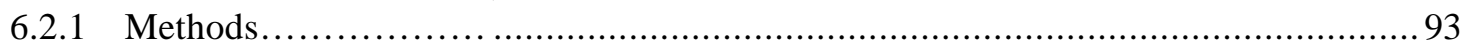

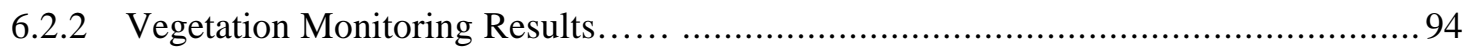

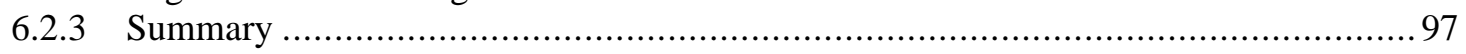

6.2.4 Maintaining Closure Cover Integrity at CAU 110, U-3ax/bl .............................. 102

7.0 MONITORING OF THE NON-PROLIFERATION TEST AND EVALUATION COMPLEX .... 104

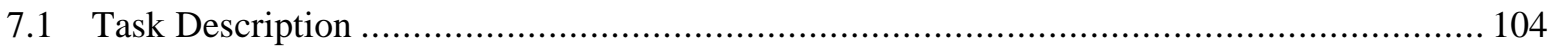

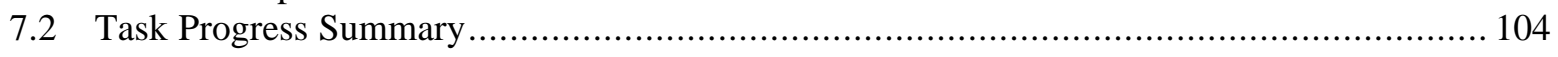

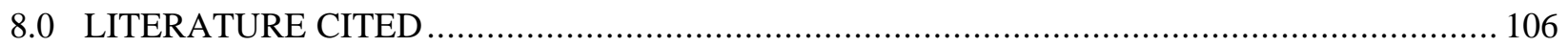

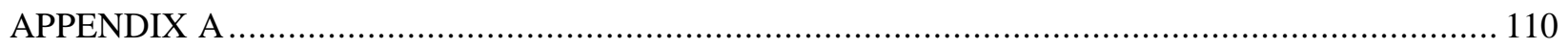

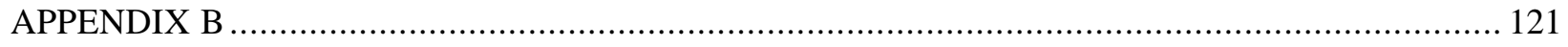

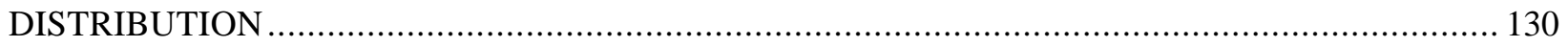

\section{List of Tables}

Table 2-1. List of sensitive and protected/regulates species known to occur on or adjacent to the NTS...4 
Table 2-2. Summary of biological surveys conducted on the NTS during 2005

Table 2-3. Total area (ha) proposed for disturbance within important habitats in 2005 and over the past seven fiscal years

Table 3-1 Summary of tortoise compliance activities conducted by BN biologists during 2005

Table 3-2 Parameters and threshold values for desert tortoise monitoring on the NTS

Table 4-1 Number and acreage of wildland fires on the NTS

Table 4-2 Inches of precipitation for meteorological recording stations on the NTS

for January through April 2005 compared to long-term averages .25

Table 4-3 Average woody and fine fuels combined index values by NTS operating area for 2005 and the average of 2004 and 2005

Table 4-4 Comparison of fuels rating for NTS sampling stations from 2004 to 2005

Table 5-1. Number of sites sampled, breeding pairs, total young, and average number of young per breeding pair by year for western burrowing owls detected with motion-activated cameras on the NTS.

Table 5-2. Western burrowing owl trapping results on the NTS, July 2005.

Table 5-3. Number of bats captured by sex (italics font) and number of electronic files of bat calls (regular font) at sites monitored in 2005.

Table 5-4. Animals sampled in 2004 at E Tunnel Pond and J-11 Pond (control site) and results reported this year.

Table 5-5. Radionuclide concentrations in animals sampled in 2004 from E Tunnel Pond 5 and J-11 Pond (control site) and results reported this year.

Table 5-6. Minutes of winter bat activity by species and month.

Table 5-7. Results of West Nile virus surveillance in 2005 on the NTS.

Table 5-8. Locations and results of mountain lion camera surveys during 2005.

Table 5-9. Results of small-mammal trapping on sandy-soil habitats in 2005.

Table 5-10. Total number of small mammals caught daily on or near Beatley Plot 65 in Area 17 of the NTS.

Table 5-11. YUF001 Plot trapping results from May 2005 compared to May 1994. 70 
Table 5-12. Number of individual horses observed on the NTS by age class, gender, and year..... .72

Table 5-13. Records of bird mortality and injuries on the NTS during 2005 .78

Table 5-14. Hydrology data from natural water sources on the NTS collected during 2005 .83

Table 5-15. Number of wildlife observed or inferred at NTS natural water sources during CY $2005 \ldots . . .84$

Table 6-1. Perennial plant densities on the Egg Point Fire restoration site 89

Table 6-2. Perennial plant densities on the upper and lower slopes of the Egg Point Fire restoration site 91

Table 6-3. Average percent plant canopy cover on U-3ax/bl closure cover from 2001 to 2005. .95

Table 6-4. Summary of plant density from 2001 to 2005 on U-3ax/bl closure cover .96

Table 6-5. Number of small mammals relocated from U-3ax/bl closure cover and adjacent areas in 2005 102

\section{List of Figures}

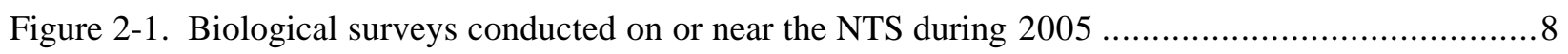

Figure 2-2. Biological surveys conducted in important habitats of the NTS during 2005 ................... 14

Figure 3-1. Biological surveys conducted in desert tortoise habitat on the NTS in 2005 .................... 17

Figure 4-1. Extended weather forecast for July, August and September of 2005 for temperature and precipitation. .26

Figure 4-2. National Wildland Fire Outlook, June 1 to June 30, 2005 .27

Figure 4-3. Index of fine fuels for 211 survey stations on the NTS by operational area during 2005.

Figure 4-4. Index of woody fuels for 211 survey stations on the NTS by operational area during 2005.

Figure 4-5. Index of combined fine fuels and woody fuels for 211 survey stations on the NTS by operational area during 2005 .

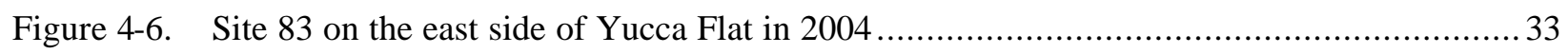

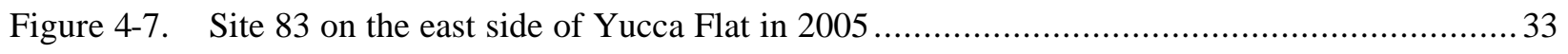

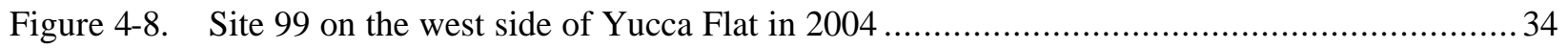




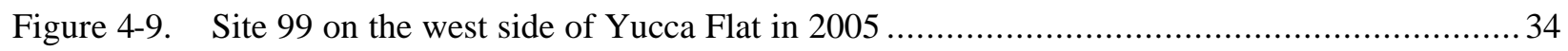

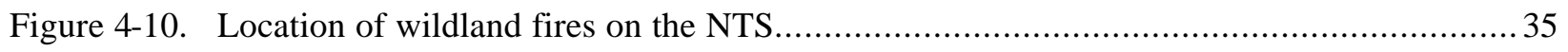

Figure 5-1. Location of sensitive plant populations monitored on the NTS during 2005 ....................39

Figure 5-2. The density of A. beatleyae at the type locality was higher this year than it

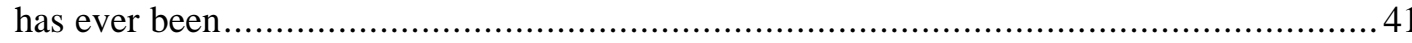

Figure 5-3 Density of A. beatleyae over the last 15 years at six of the 14 populations found

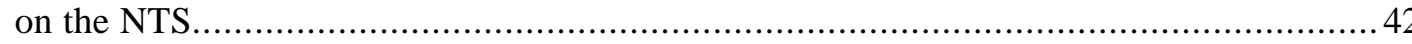

Figure 5-4. A. funereus in fruit along the southern slopes of French Peak in typical habitat: steep slopes $(35$ percent + ) and light colored volcanic tuff.

Figure 5-5. E. planoconvexus (pending verification) on northwest-facing rock cove on northern slopes of the Specter Range.

Figure 5-6 Known western burrowing owl distribution on the NTS and burrow sites where motionactivated cameras were set up and/or trapping occurred.

Figure 5-7. Western burrowing owl family on burrow apron including one adult (upper most owl), eight juveniles, and one unknown (behind front center owl) at Burrow \#51, Yucca Flat

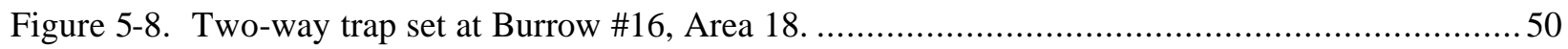

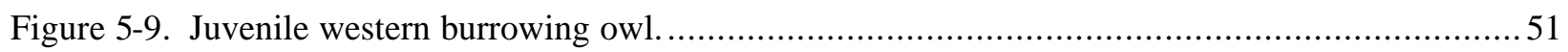

Figure 5-10. Sites monitored for bat activity during 2005 including buildings where day roosts were documented and sites sampled for biota dose assessment.

Figure 5-11. Passive acoustic monitoring system at Camp 17 Pond............................................ 58

Figure 5-12. Minutes of winter bat activity in 0.5-hour increment from sunset for California myotis, small-footed myotis, fringed myotis, and long-legged myotis.

Figure 5-13. Minutes of winter bat activity and average nightly ambient air temperature 61

Figure 5-14. Mosquito trap set at Well 5B, Frenchman Flat.

Figure 5-15. Great-horned owl nest with four eggs (Test Cell A, Area 25). .66

Figure 5-16. Three great-horned owl chicks at Wild Wing Project. 66

Figure 5-17. Horse band near Captain Jack Spring 72

Figure 5-18. Foals observed, missing foals, and foals that survived from 1990 to 1997 .73 
Figure 5-19. Trends in the age structure of the horse population from 1995 to 2005

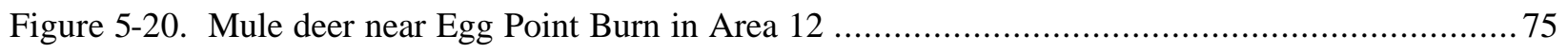

Figure 5-21. Feral horse sightings and horse sign observed on the NTS during 2005 ...................... 76

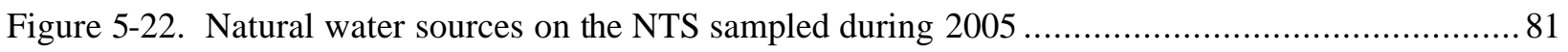

Figure 5-23. Plastic-lined Sump ER-62 monitored for wildlife mortality during 2005 ........................ 82

Figure 5-24. Constructed water sources monitored for wildlife use and mortality during 2005 .............. 86

Figure 6-1. Density of plants by lifeform on the Egg Point fire restoration site from 2003 to $2005 \ldots \ldots \ldots . .88$

Figure 6-2. Comparison of plant density on seeded and non-seeded sites on the upper slopes of Egg Point fire restoration site.

Figure 6-3. Comparison of plant density on seeded and non-seeded sites on the lower slopes Of the Egg Point Fire restoration site .93

Figure 6-4. A. confertifolia in early seed production on U-3ax/bl closure cover. .94

Figure 6-5. K. lanata and A. hymenoides in late flower/early seed production on $\mathrm{U}-3 \mathrm{ax} / \mathrm{bl}$ closure cover ....

Figure 6-6. Summary of total plant cover on the U-3ax/bl closure cover from April 2002 to May 2005.

Figure 6-7. Summary of perennial plant density on U-3ax/bl closure cover from April 2002 to May 2005 .

Figure 6-8. Comparison of vegetative cover, growth, and establishment on CAU 110, $\mathrm{U}-3 \mathrm{ax} / \mathrm{bl}$ closure cover. 101

\section{List of Appendices}

APPENDIX A Selected Photographs of NTS Sites with Various Fuel Ratings 109

APPENDIX B Historic Records of Wildland Fires on the NTS Obtained During 2005. 111 


\section{ACRONYMS AND ABBREVIATIONS}

Ac

$\mathrm{BN}$

RSL

CAU

$\mathrm{cm}$

CWA

CY

DoD

$\mathrm{DOE} / \mathrm{NV}$

DOQQ

EGIS

EIS

ELU

EMAC

ER

ESA

ESHD

$\mathrm{ft}$

FMF

FWS

FY

GIS

GPS

$\mathrm{Ha}$

HSC

in

$\mathrm{km}$

$\mathrm{m}$

mi

$\mathrm{mm}$

Acre

Bechtel Nevada

Remote Sensing Laboratory

Corrective Action Unit

Centimeter

Clean Water Act

Calendar Year

U.S. Department of Defense

U.S. Department of Energy, Nevada Operations Office

Digital Orthophoto Quarter Quadrangle

Ecological Geographic Information System

Environmental Impact Statement

Ecological Landform Unit

Ecological Monitoring and Compliance

Environmental Restoration

Endangered Species Act

Environment, Safety and Health Division

Feet

Frenchman Flat

U.S. Fish and Wildlife Service

Fiscal Year

Geographic Information System

Global Positioning System

Hectare

Hazardous Materials Spill Center

Inch

Kilometer

Meter

Mile

Millimeter 


$\begin{array}{ll}\text { NAD27 } & \text { North American Datum of } 1927 \\ \text { NAD83 } & \text { North American Datum of } 1983 \\ \text { NNHP } & \text { Nevada Natural Heritage Program } \\ \text { NNPS } & \text { Nevada Native Plant Society } \\ \text { NNSA/NSO } & \text { U.S. Department of Energy, National Nuclear Security Administration } \\ & \text { Nevada Site Office } \\ \text { NTS } & \text { Nevada Test Site } \\ \text { RMP } & \text { Resource Management Plan } \\ \text { USACE } & \text { U.S. Army Corps of Engineers } \\ \text { USGS } & \text { U.S. Geological Survey } \\ \text { UTM } & \text { Universal Transverse Mercator } \\ \text { WNV } & \text { West Nile Virus } \\ \text { yd } & \text { Yard }\end{array}$




\section{ABSTRACT}

The Ecological Monitoring and Compliance program (EMAC), funded through the U.S. Department of Energy, National Nuclear Security Administration Nevada Site Office (NNSA/NSO), monitors the ecosystem of the Nevada Test Site (NTS) and ensures compliance with laws and regulations pertaining to NTS biota. This report summarizes the program's activities conducted by Bechtel Nevada (BN) during the Calendar Year 2005. Program activities included: (1) biological surveys at proposed construction sites, (2) desert tortoise compliance, (3) ecosystem mapping and data management, (4) sensitive and protected/regulated species and unique habitat monitoring, (5) habitat restoration monitoring, and (6) biological monitoring at the Non-Proliferation Test and Evaluation Complex (NPTEC).

Sensitive and protected/regulated species of the NTS include 19 plants, 1 mollusk, 2 reptiles, over 250 birds, and 26 mammals protected, managed, or considered sensitive as per state or federal regulations and natural resource agencies and organizations. The threatened desert tortoise (Gopherus agassizii) is the only species on the NTS protected under the Endangered Species Act. Biological surveys for the presence of sensitive and protected/regulated species and important biological resources on which they depend were conducted for 35 projects. A total of 296.1 hectares (ha) (731.7 acres [ac]) was surveyed for these projects.

Sensitive and protected/regulated species and important biological resources found included: 2 inactive tortoise burrows, 1 kit fox (Vulpes velox macrotis) den, 2 western burrowing owls (Athene cunicularia hypugaea), 25 pronghorn antelope (Antilocapra americana), 6 active predator burrows, mature Joshua trees (Yucca brevifolia), yuccas and cacti; and also 24 bird nests (13 active with eggs or chicks), 4 barn owls (Tyto alba), 4 great-horned owls (Bubo virginianus), and 1 Townsend's big-eared bat (Corynorhinus townsendii pallescens) within buildings scheduled for demolition. BN provided a written summary report of all survey findings and mitigation recommendations, where applicable. All flagged burrows were avoided during construction activities. All building demolitions were conducted when buildings were confirmed to be empty of bats, active nests, and fledgling or adult birds.

Fourteen of the 35 projects had sites within the distribution range of the threatened desert tortoise. NNSA/NSO must comply with the terms and conditions of a permit (called a Biological Opinion) from the U.S. Fish and Wildlife Service (FWS) when conducting work in tortoise habitat. No tortoises were found in or displaced from project areas. No desert tortoises were accidentally injured or killed, nor were any captured or displaced from project sites. One desert tortoise was accidentally killed along a paved road. A desert tortoise habitat revegetation plan, submitted to the FWS in 2004, was approved and implemented this year. This year a total of $10.33 \mathrm{ha}(25.53 \mathrm{ac})$ of tortoise habitat was disturbed. Habitat revegetation was begun in the fall of 2005 and will continue in the spring of 2006. A description of this work and its area will be reported in next year's report.

In the spring of 2005, BN scientists prepared a Biological Assessment of the activities that were being proposed at the Test Cell C (TCC) and reported in an Environmental Assessment written in 2004. NNSA requested a Biological Opinion from FWS in April 2005. In June 2005, the FWS rendered an opinion and activities proceeded at TCC in August 2005. As per the opinion, the site was surveyed prior to testing to ensure that no tortoises were in the area. It was resurveyed in September, 2005 following the completion of testing to assess any impacts on flora or fauna. More than 25 ha $(61.8 \mathrm{ac})$ were surveyed. No damage to biota was noted during this post activity survey. A final report was written and sent to FWS as required by the Biological Opinion. 
Ecosystem mapping and data management tasks of EMAC focused on four efforts in 2005:

(1) consolidation of vegetation and site data tables into one comprehensive database to facilitate the preparation of Geographic Information System maps, (2) sampling of 28 Ecological Landform Units for plant canopy cover data and new site photographs, (3) vegetation surveys for determining wildland fire hazards, and (4) coordination with ecosystem management agencies and scientists.

Vegetation surveys were conducted along major NTS corridors in the spring of CY 2005 to determine wildland fire hazards associated with biomass produced from heavier than normal precipitation. In 2005, 221 sites were surveyed for wildland fire hazards. Highest hazards were located in Fortymile Canyon. There has been an average of 11 wildland fires per year on the NTS during the past 28 years with an average of about 218 ha $(88 \mathrm{ac})$ per fire. Areas that were previously burned had increased hazards because of invasive annual grasses that contribute a nearly continuous carpet of fine-textured fuels. Most of the wildland fires on the NTS occurred at mid-elevations in the blackbrush vegetation type.

Approximately 5,261 ha (13,000 ac) were burned during the 2005 fire season making it a year with one of the largest acreage burned during the past three decades at the NTS. The five of the largest fires of the 31 fires reported in 2005 were located near Bren Tower, Skull Mountain, Dome Mountain (the Air Force Fire), Calico Hills, and Shoshone Mountain. The burns occurred early in the fire season when soils and woody vegetation were still moist, thereby minimizing root and seed bank damage. This will increase the likelihood that many shrubs will regenerate from root sprouts and seed buried deep in the soil. Most of the sites were located in rocky areas where soil erosion will be minimal.

There were no additions or deletions to the list of sensitive plants on the NTS. There are no plant species known to occur on the NTS that are listed federally by the FWS as endangered or threatened or by the State of Nevada as critically endangered. Currently there are 18 vascular plant species and one nonvascular plant species that are listed as sensitive plant taxa by the Nevada Heritage Program (NNHP) and are known to occur or could potentially occur on the NTS. Three species were monitored (Astragalus beatleyae [Beatley's milkvetch], Astragalus funereus [Black woollypod] and Entosthodon planoconvexus [Planoconvex enthosthodon]). Six of the 14 populations of $A$. beatleyae on the NTS were selected and surveyed in 2005. Monitoring was completed in May and June when plants were in flower and setting seed. The number of individuals, averaged over the six sites that were sampled this year, was 0.30 plants $/ \mathrm{m}^{2}$ in 1989, 0.40 plants $/ \mathrm{m}^{2}$ in $1990,0.73$ plants $/ \mathrm{m}^{2}$ in $1991,0.05$ plants $/ \mathrm{m}^{2}$ in 2002 and 0.67 plants $/ \mathrm{m}^{2}$ in 2005. Plant densities this year were about what they were in 1991. In 2005, the first year with above average precipitation in several years, monitoring for A. funereus again focused on the southern slopes of French Peak, southeastern slopes of Shoshone Mountain, and the western slopes of Shoshone Mountain. Monitoring efforts began on the NTS on the southern slopes of French Peak, then the eastern and western slopes of Shoshone Mountain. About 240 plants were found at the French Peak population in June 2005. Estimates in previous years ranged from 170 to 287. The population of A. funereus surveyed on the eastern slopes of Shoshone Mountain was surveyed in 1991 and 1992 and around 30 plants were found. In 2005 there were about 20 plants. Surveys for E. planoconvexus focused on one reported location in the Specter Range near Rock Valley. Several collections were made of mosses that appeared to be E. planoconvexus on a shaded rock face about 1.6 kilometers (1 mile) from Rock Valley. Taxonomy of the specimens will be made by taxonomic experts. No apparent threats to any of the species were noted at any of the sites.

Field monitoring of sensitive and protected/regulated animals and important habitats of the NTS focused on western burrowing owls, bats, kangaroo mice (Microdipodops spp.), feral horses (Equus caballus), natural and man-made water sources, and mosquitoes for West Nile Virus (WNV). Twelve sites were monitored for bat use. 
Of these sites, seven were water sources and five were tunnels or abandoned mines. Acoustic monitoring at these sites yielded 1,670 electronic files representing 12 species including 10 sensitive and/or protected/regulated bat species. Of the 15 known bat species to occur on the NTS, all but the silverhaired bat (Lasionycteris noctivagans) and the Townsend's big-eared bat were detected. No new species were detected in 2005. In conjunction with routine bat monitoring, 37 bats ( 7 species) and 10.3 grams of flying insects were collected to assess radiation doses. Dose rates to bats from internal man-made radionuclides ranged from $7.0 \times 10^{-9} \mathrm{Rad} /$ day to $2.0 \times 10^{-5} \mathrm{Rad} /$ day (mean $8.0 \times 10^{-6} \mathrm{rad} / \mathrm{day}$; median $7.0 \times 10^{-6} \mathrm{rad} /$ day) and were predominantly from tritium. These levels are less than $1 \%$ of the DOE recommended dose limit of $0.1 \mathrm{Rad} /$ day for the protection of terrestrial biota. These data suggest that bats drinking and foraging over E Tunnel Pond 5 are not receiving internal doses from man-made radionuclides that would be considered harmful.

Monitoring of the western burrowing owl entailed assessing reproduction with remote cameras and trapping owls at their burrows. Additionally, five new burrow sites were found including two burrows in the Mojave Desert Ecoregion, two in the Transition Ecoregion, and one in the Great Basin Desert Ecoregion. This makes a total of 126 known western burrowing owl locations (30 owl sightings and 96 burrow sites) on the NTS. Eighteen sites were sampled and a total of 58 young were detected for an average of 5.3 young owls per pair. Traps were set out at 10 burrow sites for a total of 33 trap nights. Twenty-two owls including one adult and 21 juveniles were captured and banded.

The direct population count of feral horses in 2005 was 49 individuals, not including foals, compared to 44 individuals the year before. Five horse bands (composed of stallions, subordinate males, females, and their offspring) were detected this year. Bands observed ranged in size from 3 to 13 individuals excluding foals. Five foals were observed with their mares from June-December. The population showed a moderate increase in number over last year due to the recent survival of several younger aged horses (yearling to two-year olds).

Twelve raptor mortalities were recorded in 2005. Two of the primary causes of bird mortality were road kill and electrocution. Three birds were injured and taken to Wild Wing Project, Inc. in Las Vegas. Two of the three were so severely injured they had to be euthanized and the third was rehabilitated and released at Corn Creek Wildlife Refuge.

Twelve wetlands, 39 plastic-lined sumps, three earthen ponds, Well 3 Area 6, LANL Pond Area 6, Well $5 \mathrm{~b}$, and two radioactive containment ponds were monitored. These were monitored at least once during the year to record dead animals, the presence/absence of land disturbance, water flow rates, and surface area of standing water. No animal mortalities were reported in plastic-lined sumps during 2005.

Ten sites were sampled during 16 surveys for mosquitoes to determine if West Nile Virus (WNV) occurs on the NTS. A total of 77 individual mosquitoes representing three species were captured and analyzed. All specimens tested for WNV were negative except for one individual which was suspect. Suspect means inconclusive, neither positive nor negative. Further monitoring will be conducted in 2006.

NTS sites which have been revegetated are periodically monitored under EMAC. Monitoring revegetation success documents methodology and helps develop better techniques for site restoration. At the Egg Point Fire burn site, line transects were sampled. Density of seeded species was 1.98 plants per square meter (plants $/ \mathrm{m}^{2)}$ ) on upper slopes and 1.43 plants $/ \mathrm{m}^{2}$ on lower slopes in 2005 , compared to 1.88 plants $/ \mathrm{m}^{2}$ and 0.87 plants $/ \mathrm{m}^{2}$ on upper and lower slopes, respectively for 2004 . The density of perennial plants on non-seeded areas was 27 percent of the density of the seeded areas. There were about 
44 percent as many shrubs, 15 percent as many grasses, and about 22 percent as many forbs as on the seeded sites showing the importance of reseeding to reestablish vegetation.

Although not part of the EMAC program, habitat restoration at CAU, U-3ax/bl Closure Cover was monitored in 2005 to document success of revegetation completed in 2000. Plant cover increased from 12.8 percent in 2004 to 20.2 percent in 2005 . This is a good indication that native plant species on the closure cover have successfully survived the drought conditions that followed reseeding in 2000.

Perennial plant cover was 17 percent, a significant increase over the 2 percent just two years ago. Seeded areas had significantly higher perennial species cover and plant density than did unseeded areas, which were primarily comprised of weedy annual species. There was abundant growth of native annual plants during the spring of 2005 because of the higher than normal precipitation that was received on the NTS. In addition to vegetation monitoring in 2005, small mammals were trapped and relocated off the cover site to remove the effect that burrowing animals might have on the integrity of the closure cover. During the twelve-trap nights (three trapping sessions) 190 animals were captured and relocated.

Chemical release test plans for two activities, Divine Shrake and Scorpion, at the Non-Proliferation Test and Evaluation Complex (NPTEC; formerly the Hazardous Materials Spill Center) on Frenchman Lake playa were reviewed. Because chemical releases were such low volumes or low toxicity there was no need to monitor downwind transects for biological impacts. Seasonal sampling of downwind and upwind transects near the NPTEC was conducted to document baseline conditions of biota. No differences in biota were noted along downwind (treatment) versus upwind (control) transects. 


\subsection{INTRODUCTION}

In accordance with U.S. Department of Energy Order DOE O 450.1, "Environmental Protection Program," the Office of the Assistant Manager for Safety Programs of the U.S. Department of Energy, National Nuclear Security Administration Nevada Site Operations Office (NNSA/NSO) requires ecological monitoring and biological compliance support for activities and programs conducted at the Nevada Test Site (NTS). Bechtel Nevada (BN) Ecological Services has implemented the Ecological Monitoring and Compliance Program (EMAC) to provide this support. EMAC is designed to ensure compliance with applicable laws and regulations, delineate and define NTS ecosystems, and provide ecological information that can be used to predict and evaluate the potential impacts of proposed projects and programs on those ecosystems.

This report summarizes the program's activities conducted by BN during the calendar year 2005 . Monitoring tasked during 2005 included six program areas: (a) biological surveys, (b) desert tortoise compliance, (c) ecosystem mapping and data management, (d) sensitive and protected/regulated species and habitat monitoring, (e) habitat restoration monitoring, and (f) biological monitoring at the NonProliferation Test and Evaluation Complex (NPTEC). The following sections of this report describe work performed under these six areas. 
THIS PAGE IS INTENTIONALLY LEFT BLANK 


\subsection{BIOLOGICAL SURVEYS}

Biological surveys are performed at proposed project sites where land disturbance will occur. The goal is to minimize adverse effects of land disturbance on sensitive and protected/regulated plant and animal species (Table 2-1), their associated habitat, and important biological resources. Sensitive species are defined as species that are at risk of extinction or serious decline or whose long-term viability has been identified as a concern. They include species on the Nevada Natural Heritage Program's (NNHP) sensitive plant and animal lists and bat species ranked as moderate or high in the Nevada Bat Conservation Plan Bat Species Risk Assessment. Protected/regulated species are those that are protected or regulated by federal or state law. Many species are both sensitive and protected/regulated (Table 2-1). Important biological resources include such things as cover sites, nest or burrow sites, roost sites, or water sources important to sensitive species. Survey reports are written to document species and resources found and to provide mitigation recommendations.

\subsection{Sites Surveyed and Sensitive and Protected/Regulated Species Observed}

Biological surveys for 35 projects were conducted on or near the NTS (Figure 2-1, Table 2-2). For some of these projects multiple sites were surveyed (Figure 2-1). A total of 296.1 hectares (ha) (731.7 acres [ac]) were surveyed for these projects (Table 2-2). Eighteen of the projects had sites within the distribution range of the threatened desert tortoise (Gopherus agassizii). Sensitive and protected/regulated species and important biological resources found included: 2 inactive tortoise burrows, 1 kit fox den, 2 burrowing owls, 25 antelope, 6 active predator burrows, mature Joshua trees, yuccas and cacti; and also 24 bird nests (13 active with eggs or chicks), 4 barn owls, 4 great-horned owls, and 1 bat within buildings scheduled for demolition (Table 2-2). BN provided a written summary report of all survey findings and mitigation recommendations, where applicable (Table 2-2). All flagged burrows were avoided during construction activities. All building demolitions were conducted when buildings were confirmed to be empty of bats, active nests, and fledgling or adult birds.

\subsection{Potential Habitat Disturbance}

Surveys are conducted at old industrial or nuclear weapons testing sites whenever vegetation has recolonized a site or it is suspected that a sensitive or protected/regulated species could be found. For example, tortoises may move through revegetated earthen sumps and may be concealed under vegetation during activities when heavy equipment is used. Preactivity surveys are conducted at such revegetated sites to ensure that they are not in harm's way. Also, burrowing owls frequently inhabit burrows and culverts at disturbed sites, so preactivity surveys are conducted to ensure that adults, eggs, and nestlings in burrows are not harmed.

Twenty of the projects for which surveys were conducted were entirely on sites previously disturbed (e.g., building sites, industrial waste sites, existing well pads, and road shoulders) (Table 2-2). Fifteen projects were located either partially or entirely in areas that had not been previously disturbed. These projects have the potential to disturb a total of 119.71 ha $(295.81 \mathrm{ac})$. Most of the area that could be disturbed was associated with the Scorpion tests (Project No. 05-23) which dealt with short-term release of potentially toxic materials or surrogates into the air for sensor testing and dispersion modeling (Table 2-2). 
Table 2-1. List of sensitive and protected/regulated species known to occur on or adjacent to the NTS.

\begin{tabular}{lll}
\hline \hline SENSITIVE PLANT SPECIES & Common Names & Status $^{\text {a }}$ \\
\hline \hline Flowering Plant Species & & \\
\hline Astragalus beatleyae & Beatley's milkvetch & S, A \\
Astragalus funereus & Black woolypod & S, A \\
Astragalus oopherus var. clokeyanus & Clokey's egg milkvetch & S, A \\
Eriogonum concinnum & Darin's buckwheat & S, A \\
Eriogonum heermannii var. clokeyi & Clokey's buckwheat & S, A \\
Ivesia arizonica var. saxosa & Whitefeather ivesia & S, A \\
Lathyrus hitchcockianus & Hitchcock's peavine & S, A \\
Phacelia beatleyae & Beatley's phacelia & S, A \\
Arctomecon merriamii & White bearpoppy & S, IA \\
Camissonia megalantha & Cane Spring suncup & S, IA \\
Cymopterus ripleyi & Ripley's springparsley & S, IA \\
Frasera albicaulis var. modocensis & Modoc elkweed & S, IA \\
Galium hilendiae ssp. kingstonense & Kingston Mountain bedstraw & S, IA \\
Hulsea vestita ssp. inyoensis & Inyo hulsea & S, IA \\
Penstemon pahutensis & Pahute penstemon & S, IA \\
Phacelia mustelina & Weasel phacelia & S, IA \\
Phacelia parishii & Parish's phacelia & S, IA \\
Sclerocactus polyancistrus & Mojave fishhook cactus & CY, S, IA \\
\hline & & \\
\hline & & \\
\hline
\end{tabular}

\section{Moss Species}

\begin{tabular}{lll}
\hline Entosthodon planoconvexus & Planoconvex entosthodon & S, E \\
\hline \hline \multicolumn{2}{l|}{ PROTECTED/REGULATED PLANT SPECIES } & \\
\hline \hline Cactaceae & Cacti (16 species) & $\mathrm{CY}$ \\
Agavaceae & Yucca (3 species), Agave (1 species) & $\mathrm{CY}$ \\
Pinus monophylla/Juniperus osteosperma & Pinyon/Juniper & $\mathrm{CY}$ \\
\hline
\end{tabular}


Table 2-1 Continued

\begin{tabular}{|c|c|c|}
\hline SENSITIVE ANIMAL SPECIES & Common Name & Status ${ }^{a}$ \\
\hline \multicolumn{3}{|l|}{ Mollusk Species } \\
\hline Pyrgulopsis turbatrix & Southeast Nevada springsnail & $\mathrm{S}, \mathrm{A}$ \\
\hline \multicolumn{3}{|l|}{ Reptile Species } \\
\hline Eumeces gilberti rubricaudatus & Western red-tailed skink & $\mathrm{S}, \mathrm{E}$ \\
\hline Gopherus agassizii & Desert tortoise & LT, S, NP, IA \\
\hline \multicolumn{3}{|l|}{ Bird Species } \\
\hline Accipiter gentilis & Northern goshawk & S, NPS, IA \\
\hline Athene cunicularia hypugaea & Western burrowing owl & $\mathrm{S}, \mathrm{NP}, \mathrm{A}$ \\
\hline Buteo regalis & Ferruginous hawk & S, NP, IA \\
\hline Buteo swainsoni & Swainson's hawk & $\mathrm{S}, \mathrm{NP}, \mathrm{A}$ \\
\hline Chlidonias niger & Black tern & S, NP, IA \\
\hline Соссуzus americanus & Western yellow-billed cuckoo & S, NPS, IA \\
\hline Falco peregrinus anatum & American peregrine falcon & $<\mathrm{LE}, \mathrm{S}, \mathrm{NPE}, \mathrm{IA}$ \\
\hline Gavia immer & Common loon & S, NP, IA \\
\hline Haliaeetus leucocephalus & Bald eagle & $\begin{array}{l}\text { LT-PD, EA, S, NPE, } \\
\text { IA }\end{array}$ \\
\hline Ixobrychus exillis hesperis & Western least bittern & $\mathrm{S}, \mathrm{NP}, \mathrm{IA}$ \\
\hline Phainopepla nitens & Phainopepla & S, NP, IA \\
\hline Plegadis chihi & White-faced ibis & S, NP, IA \\
\hline \multicolumn{3}{|l|}{ Mammal Species } \\
\hline Antrozous pallidus & Pallid bat & $\mathrm{M}, \mathrm{NP}, \mathrm{A}$ \\
\hline Corynorhinus townsendii pallescens & Townsend's big-eared bat & H, NPS, A \\
\hline Euderma maculatum & Spotted bat & $\mathrm{M}, \mathrm{NPT}, \mathrm{A}$ \\
\hline Lasionycteris noctivagans & Silver-haired bat & $\mathrm{M}, \mathrm{A}$ \\
\hline Lasiurus blossevillii & Western red bat & $\mathrm{H}, \mathrm{NPS}, \mathrm{A}$ \\
\hline
\end{tabular}




\begin{tabular}{lll} 
Table 2-1 Continued & Common Name & Status $^{\mathbf{a}}$ \\
\hline \hline Lasiurus cinereus & Hoary bat & $\mathrm{M}, \mathrm{A}$ \\
Myotis californicus & California myotis & $\mathrm{M}, \mathrm{A}$ \\
Myotis ciliolabrum & Small-footed myotis & $\mathrm{M}, \mathrm{A}$ \\
Myotis evotis & Long-eared myotis & $\mathrm{M}, \mathrm{A}$ \\
Myotis thysanodes & Fringed myotis & $\mathrm{H}, \mathrm{NP}, \mathrm{A}$ \\
Myotis yumanensis & Yuma myotis & $\mathrm{M}, \mathrm{A}$ \\
Pipistrellus hesperus & Western pipistrelle & $\mathrm{M}, \mathrm{A}$ \\
& & \\
\hline \hline
\end{tabular}

\section{PROTECTED/REGULATED ANIMAL SPECIES}

\section{Bird Species $^{b}$}

\begin{tabular}{lll}
\hline Alectoris chukar & Chukar & $\mathrm{G}$ \\
Aquila chrysaetos & Golden eagle & $\mathrm{EA}, \mathrm{NP}$ \\
Callipepla gambelii & Gambel's quail & $\mathrm{G}$ \\
Charadrius montanus & Mountain plover & PT, NP \\
Lanius ludovicianus & Loggerhead shrike & NPS \\
Oreoscoptes montanus & Sage thrasher & NPS \\
Spizella breweri & Brewer's sparrow & NPS \\
& & \\
\hline
\end{tabular}

\section{Mammal Species}

\begin{tabular}{lll}
\hline Antilocapra americana & Pronghorn antelope & $\mathrm{G}$ \\
Equus asinus & Burro & $\mathrm{H} \& \mathrm{~B}$ \\
Equus caballus & Horse & $\mathrm{H} \& \mathrm{~B}$ \\
Felis concolor & Mountain lion & $\mathrm{G}$ \\
Lynx rufus & Bobcat & $\mathrm{F}$ \\
Microdipodops megacephalus & Dark kangaroo mouse & $\mathrm{NP}$ \\
Microdipodops pallidus & Pale kangaroo mouse & $\mathrm{NP}$ \\
Ovis canadensis nelsoni & Desert bighorn sheep & $\mathrm{G}$ \\
Odocoileus hemionus & Mule deer & $\mathrm{G}$ \\
Sylvilagus audubonii & Audubon's cottontail & $\mathrm{G}$ \\
Sylvilagus nuttallii & Nuttall's cottontail & $\mathrm{G}$
\end{tabular}




\begin{tabular}{lll} 
Table 2-1 Continued & Common Name & Status $^{\text {a }}$ \\
\hline \hline Tadarida brasiliensis & Brazilian free-tailed bat & NP \\
Urocyon cinereoargenteus & Gray fox & $\mathrm{F}$ \\
Vulpes velox macrotis & Kit fox & $\mathrm{F}$ \\
\hline \hline
\end{tabular}

a Status Codes:

Endangered Species Act, U.S. Fish and Wildlife Service

LT - Listed Threatened

PT - Proposed for listing as Threatened

PD - Proposed for delisting

$<\mathrm{LE}$ - Former listed endangered species

U.S. Department of Interior

H\&B - Protected under Wild Free Roaming Horses and Burros Act

EA - Protected under Bald and Golden Eagle Act

State of Nevada-Animals

S - Nevada Natural Heritage Program-Sensitive Animal Taxa

NPE - Nevada Protected-Endangered, species protected under NAC 503

NPT - Nevada Protected-Threatened, species protected under NAC 503

NPS - Nevada Protected-Sensitive, species protected under NAC 503

NP - Nevada Protected, species protected under NAC 503

$\mathrm{G}$ - Regulated as game species

F - Regulated as fur-bearer species

State of Nevada-Plants

S - Nevada Natural Heritage Program-Sensitive Plant Taxa - Detailed Rare Plant and Lichen List

CY - Protected as a cactus, yucca, or Christmas tree

Long-term Monitoring Status for Nevada Test Site (NTS) (see Section 5.0 of this report)
A - Active
IA - Inactive
E - Evaluate

Nevada Bat Conservation Plan - Bat Species Risk Assessment

$\mathrm{H}$ - High

M - Moderate

b All bird species on the NTS are protected by the Migratory Bird Treaty Act except for Chukar, Gambel's quail, English house sparrow, Rock dove, and European starling. 


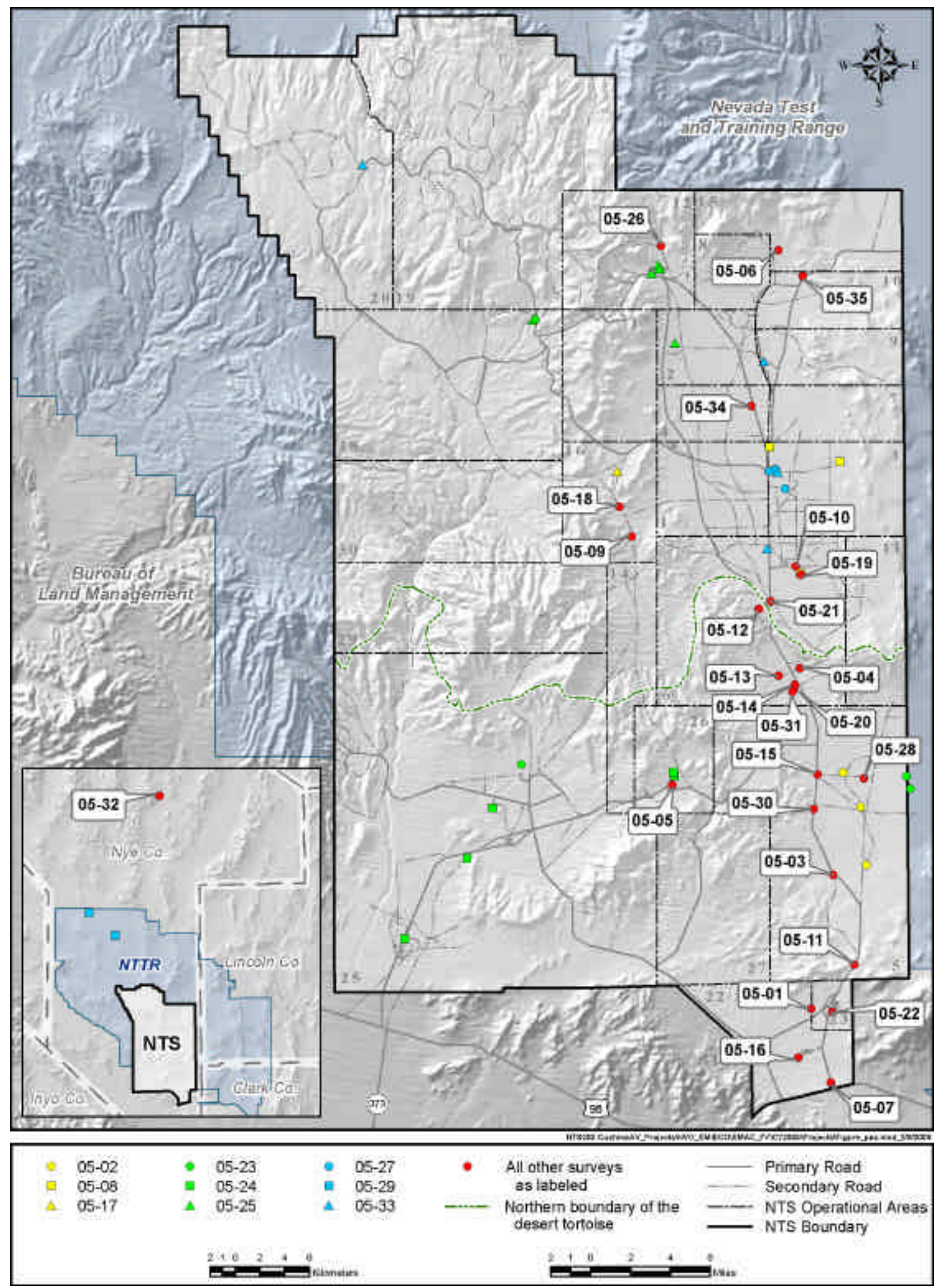

Figure 2-1. Biological surveys conducted on and near the NTS during 2005 
Table 2-2. Summary of biological surveys conducted on the NTS during 2005.

\begin{tabular}{|c|c|c|c|c|c|}
\hline $\begin{array}{l}\text { Project } \\
\text { No. }\end{array}$ & Project & $\begin{array}{l}\text { Important } \\
\text { Species/ Resources } \\
\text { Found }\end{array}$ & $\begin{array}{l}\text { Area } \\
\text { Surveyed ha } \\
\text { (acres) }\end{array}$ & $\begin{array}{c}\text { Proposed Project } \\
\text { Area in } \\
\text { Undisturbed } \\
\text { Habitat in ha (acres) }\end{array}$ & $\begin{array}{c}\text { Mitigation } \\
\text { Recommendations }\end{array}$ \\
\hline $05 \mathrm{BD}^{\mathrm{a}}$ & Building demolitions (20 buildings) & $\begin{array}{l}10 \text { empty passerine bird nests, } \\
8 \text { nests with over } 26 \text { eggs, } \\
4 \text { nests with } 10 \text { nestlings }\end{array}$ & 0 & 0 & $\begin{array}{l}\text { Postpone demolition until eggs have } \\
\text { hatched and nestlings have fledged. } 2 \\
\text { barn owl eggs and } 4 \text { great-horned owl } \\
\text { eggs were taken to Wild Wing } \\
\text { Project, Inc. with FWS approval. } \\
\text { (Empty nests were removed). }\end{array}$ \\
\hline $05-01$ & Mercury Landfill Borrow Pit & $\begin{array}{l}\text { Potential desert tortoise burrow, } \\
\text { burrowing owl using this burrow }\end{array}$ & $3.53(8.72)$ & $0.88(2.18)$ & $\begin{array}{l}\text { Monitor burrow to see if owls are } \\
\text { using it; Avoid flagged potential } \\
\text { tortoise burrow }\end{array}$ \\
\hline $05-02$ & CAU 140 (6 CAS sites) & None & $2.06(5.09)$ & 0 & None \\
\hline $05-03$ & CAU 115 Test Cell A & Bird nest in building & $5.85(14.46)$ & 0 & $\begin{array}{l}\text { Remove bird nest before it is } \\
\text { occupied }\end{array}$ \\
\hline $05-04$ & Area 6 Waterline & Joshua trees/cacti & $27.46(67.85)$ & $3.85(9.51)$ & Avoid Joshua trees/cacti if possible \\
\hline $05-05$ & CAU 165 (CAS 26-59-01) & None & $0.42(1.04)$ & 0 & None \\
\hline $05-06$ & CAU 543 EPA Farm & None & $1.24(3.06)$ & 0 & None \\
\hline $05-07$ & Mercury Highway Roadside Blading & None & $9.13(22.56)$ & 0 & None \\
\hline $05-08$ & CAU 511 Waste Dumps (3 sites) & None & $3.64(8.99)$ & 0 & None \\
\hline $05-09$ & ER 16-1 Access Road & 3 empty bird nests and several cacti & $5.10(12.61)$ & 0 & $\begin{array}{l}\text { Activities should begin before nests } \\
\text { are reoccupied }\end{array}$ \\
\hline $05-10$ & Unicorn Power line & None & $2.45(6.05)$ & $0.81(2.00)$ & None \\
\hline $05-11$ & 200 Hill & None & $0.16(0.40)$ & 0 & None \\
\hline $05-12$ & Area 6 Gravel Pit extension & Inactive predator burrow & $2.18(5.38)$ & $1.31(3.24)$ & None \\
\hline $05-13$ & ASP and Power line & Active bird nest; Joshua trees-cacti & $7.47(18.46)$ & $0.81(2.00)$ & $\begin{array}{l}\text { Monitor bird nest and avoid Joshua } \\
\text { trees/cacti if possible }\end{array}$ \\
\hline
\end{tabular}


Table 2-2. (Continued)

\begin{tabular}{|c|c|c|c|c|c|}
\hline $\begin{array}{l}\text { Project } \\
\text { Number }\end{array}$ & Project & $\begin{array}{c}\text { Important } \\
\text { Species/ Resources } \\
\text { Found }\end{array}$ & $\begin{array}{c}\text { Area } \\
\text { Surveyed in } \\
\text { ha (acres) }\end{array}$ & $\begin{array}{c}\text { Proposed Project } \\
\text { Area in } \\
\text { Undisturbed } \\
\text { Habitat in ha } \\
\text { (acres) }\end{array}$ & $\begin{array}{c}\text { Mitigation } \\
\text { Recommendations }\end{array}$ \\
\hline $05-14$ & NCCT Trenches & Joshua trees & $1.60(3.95)$ & $0.06(0.15)$ & Avoid Joshua trees if possible \\
\hline $05-15$ & Area 5 Water Tanks & Inactive predator burrow & $2.34(5.78)$ & $0.05(0.12)$ & None \\
\hline $05-16$ & CAU 329 Desert Rock Airport & None & $0.30(0.74)$ & 0 & None \\
\hline $05-17$ & CAU 219 (4 sites) & None & $0.95(2.34)$ & $0.28(0.69)$ & None \\
\hline $05-18$ & Area 16 Borrow Pit & None & $0.14(0.34)$ & $0.13(0.33)$ & None \\
\hline 05-19 & Well C-1 Pipeline & None & $2.76(6.82)$ & $1.23(3.03)$ & None \\
\hline $05-20$ & NCCT Facilities & Joshua trees & $5.43(13.40)$ & $4.36(10.77)$ & Avoid Joshua trees if possible \\
\hline $05-21$ & Fire Station No 2 & None & $1.26(3.11)$ & 0 & None \\
\hline $05-22$ & Fire Station No 1 & Mojave Yuccas & $6.42(15.86)$ & 0 & Avoid Mojave Yuccas if possible \\
\hline $05-23$ & Scorpion (3 sites) & $\begin{array}{l}\text { Several kit fox burrows, } \\
\text { predator burrows, antelope }\end{array}$ & $\begin{array}{c}105.15 \\
(259.83)\end{array}$ & $\begin{array}{c}94.64 \\
(233.85)\end{array}$ & $\begin{array}{l}\text { Avoid testing when antelope are } \\
\text { present; monitor after testing }\end{array}$ \\
\hline $05-24$ & CAU 168 (5 sites) & None & $2.99(7.39)$ & $0.04(0.10)$ & None \\
\hline $05-25$ & CAU 151 (8 sites) & None & $6.68(16.51)$ & 0 & None \\
\hline $05-26$ & Area 12 T-Tunnel & $\begin{array}{l}1 \text { inactive nest, several } \\
\text { yuccas and cacti }\end{array}$ & $2.38(5.88)$ & 0 & Avoid yuccas and cacti if possible \\
\hline $05-27$ & CAU 145 (6 sites) & None & $0.70(1.73)$ & 0 & None \\
\hline $05-28$ & CAU 534 (1 site) & None & $0.05(0.12)$ & 0 & None \\
\hline $05-29^{c}$ & TTR CAU 489 (2 sites) & None & $0.46(1.14)$ & 0 & None \\
\hline
\end{tabular}


Table 2-2. (Continued)

\begin{tabular}{|c|c|c|c|c|c|}
\hline $\begin{array}{l}\text { Project } \\
\text { Number }\end{array}$ & Project & $\begin{array}{c}\text { Important } \\
\text { Species/ Resources } \\
\text { Found }\end{array}$ & $\begin{array}{c}\text { Area } \\
\text { Surveyed in } \\
\text { ha (acres) }\end{array}$ & $\begin{array}{c}\text { Proposed Project } \\
\text { Area in } \\
\text { Undisturbed } \\
\text { Habitat in ha } \\
\text { (acres) }\end{array}$ & $\begin{array}{c}\text { Mitigation } \\
\text { Recommendations }\end{array}$ \\
\hline 05-30 & $\begin{array}{l}\text { Mercury Highway Roadside Blading - Frenchman } \\
\text { Flat to CP }\end{array}$ & None & $\begin{array}{c}64.40 \\
(159.10)\end{array}$ & 0 & None \\
\hline $05-31$ & Rad/NucCTEC Storm Drainage Channel & Joshua trees & $3.95(9.76)$ & $1.08(2.67)$ & Avoid Joshua trees if possible \\
\hline $05-32^{\mathrm{c}}$ & CNTA - Drill site & several cacti & $1.20(3.00)$ & $0.84(2.08)$ & $\begin{array}{l}\text { Avoid cacti or replant if possible } \\
\text { Reclaim site when complete }\end{array}$ \\
\hline $05-33$ & CAU 247) (5 sites) & None & $0.05(0.12)$ & 0 & None \\
\hline 05-34 & Phoenix & None & $0.85(2.10)$ & 0 & None \\
\hline \multirow[t]{2}{*}{$05-35$} & Power Line & $\begin{array}{l}2 \text { predator burrow, } 1 \text { kit fox } \\
\text { den }\end{array}$ & $\begin{array}{c}17.54 \\
(43.34) \\
\end{array}$ & $\begin{array}{c}9.48 \\
(23.43) \\
\end{array}$ & Avoid burrows if possible \\
\hline & & $\begin{array}{c}\text { Totals in ha } \\
\text { (ac) }\end{array}$ & $\begin{array}{c}296.10 \\
(731.68)\end{array}$ & $\begin{array}{c}119.71 \\
(295.81)\end{array}$ & \\
\hline
\end{tabular}

${ }^{\mathrm{a}}$ Building locations not shown on Figure 2-1; ${ }^{\mathrm{b}} \mathrm{CAU}=$ Corrective Action Unit; ${ }^{\mathrm{c}}$ Site was not on the NTS. 
Seventeen of the projects that will cause new disturbances occur in areas designated as important habitat (Table 2-3, Figure 2-2). During vegetation mapping of the NTS, Ecological Landform Units (ELUs) were evaluated and some were identified as Pristine (having few man-made disturbances), Unique (containing uncommon biological resources such as a natural wetland), Sensitive (containing vegetation associations which recover very slowly from direct disturbance), and Diverse (having high plant species diversity) (DOE/NV, 1998). A single ELU could be classified as more than one type of important habitat. Figure 2-2 shows the distribution of these important habitats which were ranked so that pristine habitat overlays unique, which then overlays sensitive, which then overlays diverse habitat. The expected area to be disturbed in important habitat due to 2005 projects is 42.84 ha (105.86 ac)(Table 2-3). Since FY 1999, a tally of all acreage proposed for disturbance within important habitats has been kept (Table 2-3). This tally may be used in the future to estimate the area and rate of establishment of invasive species into these habitats. Land-disturbing activities are known to cause the spread of invasive species such as Bromus rubens (red brome) into areas of the NTS where they have not occurred previously. Such non-native weeds can degrade important habitats by decreasing plant biodiversity and increasing the risk and spread of wildfires. The monitoring and control of invasive plants on federal lands is encouraged under Executive Order 13112, Invasive Species. 
Table 2-3. Total area (in hectares) proposed for disturbance within important habitats in 2005 and over the past seven fiscal years.

\begin{tabular}{|c|c|c|c|c|c|}
\hline $\begin{array}{l}\text { Project } \\
\text { No. }\end{array}$ & Project Name & $\begin{array}{l}\text { Pristine } \\
\text { Habitat }\end{array}$ & $\begin{array}{l}\text { Unique } \\
\text { Habitat }\end{array}$ & $\begin{array}{c}\text { Sensitive } \\
\text { Habitat }\end{array}$ & Diverse Habitat \\
\hline 05-01 & Area 23 Landfill Borrow Pit & $0^{\mathrm{a}}$ & $0^{\mathrm{a}}$ & $0^{\mathrm{a}}$ & 0.88 \\
\hline $05-02$ & CAU 140 CAS 05-17-01 & $0^{\mathrm{a}}$ & $0^{\mathrm{a}}$ & $0.00^{\mathrm{b}}$ & $0^{\mathrm{a}}$ \\
\hline $05-02$ & CAU 140 CAS 05-99-04 & $0^{\mathrm{a}}$ & $0^{\mathrm{a}}$ & $0.00^{\mathrm{b}}$ & $0^{\mathrm{a}}$ \\
\hline $05-03$ & CAU 115 Test Cell A & $0^{\mathrm{a}}$ & $0^{\mathrm{a}}$ & $0.00^{\mathrm{b}}$ & $0^{\mathrm{a}}$ \\
\hline $05-05$ & CAU 165 CAS 26-59-01 & $0^{\mathrm{a}}$ & $0^{\mathrm{a}}$ & $0.00^{\mathrm{b}}$ & $0^{\mathrm{a}}$ \\
\hline 05-09 & ER 16-1 Access Road & $0^{\mathrm{a}}$ & $0^{\mathrm{a}}$ & $0.00^{\mathrm{b}}$ & $0^{\mathrm{a}}$ \\
\hline $05-12$ & Area 6 Gravel Pit Extension & $0^{\mathrm{a}}$ & $0^{\mathrm{a}}$ & 1.31 & $0^{\mathrm{a}}$ \\
\hline $05-13$ & ASP & $0^{\mathrm{a}}$ & 0.81 & $0^{\mathrm{a}}$ & $0^{\mathrm{a}}$ \\
\hline $05-14$ & Rad/NucCTEC Trenches & $0^{\mathrm{a}}$ & $0^{\mathrm{a}}$ & 0.06 & $0^{\mathrm{a}}$ \\
\hline $05-20$ & Rad/NucCTEC Test Facilities & $0^{\mathrm{a}}$ & $0^{\mathrm{a}}$ & 4.36 & $0^{\mathrm{a}}$ \\
\hline $05-23$ & Scorpion Test Cell C & $0^{\mathrm{a}}$ & $0^{\mathrm{a}}$ & $0.00^{\mathrm{b}}$ & $0^{\mathrm{a}}$ \\
\hline $05-23$ & Scorpion - Small Mortar & $0^{\mathrm{a}}$ & $0^{\mathrm{a}}$ & $0.00^{\mathrm{b}}$ & $0^{\mathrm{a}}$ \\
\hline $05-24$ & CAU 168 - 25-16-01 & $0^{\mathrm{a}}$ & $0^{\mathrm{a}}$ & $0.00^{\mathrm{b}}$ & $0^{\mathrm{a}}$ \\
\hline $05-24$ & CAU 168 - 26-08-01 & $0^{\mathrm{a}}$ & $0^{\mathrm{a}}$ & 0.04 & $0^{\mathrm{a}}$ \\
\hline $05-24$ & CAU 168 - 26-17-01 & $0.00^{\mathrm{b}}$ & $0^{\mathrm{a}}$ & $0^{\mathrm{a}}$ & $0^{\mathrm{a}}$ \\
\hline $05-25$ & CAU $151-02-05-01$ & $0^{\mathrm{a}}$ & $0^{\mathrm{a}}$ & $0.00^{\mathrm{b}}$ & $0^{\mathrm{a}}$ \\
\hline $05-25$ & CAU 151 - 12-04-01 & $0^{\mathrm{a}}$ & $0^{\mathrm{a}}$ & $0.00^{\mathrm{b}}$ & $0^{\mathrm{a}}$ \\
\hline $05-25$ & CAU 151 - 12-04-02 & $0^{\mathrm{a}}$ & $0^{\mathrm{a}}$ & $0.00^{\mathrm{b}}$ & $0^{\mathrm{a}}$ \\
\hline $05-25$ & CAU 151 - 12-04-03 & $0^{\mathrm{a}}$ & $0^{\mathrm{a}}$ & $0.00^{\mathrm{b}}$ & $0^{\mathrm{a}}$ \\
\hline $05-26$ & Area $12 \mathrm{~T}$-Tunnel & $0^{\mathrm{a}}$ & $0^{\mathrm{a}}$ & $0.00^{\mathrm{b}}$ & $0^{\mathrm{a}}$ \\
\hline $05-28$ & CAU 534 & $0^{\mathrm{a}}$ & $0^{\mathrm{a}}$ & $0.00^{\mathrm{b}}$ & $0^{\mathrm{a}}$ \\
\hline $05-31$ & Rad/Nuc/CTEC Storm Berm & $0^{\mathrm{a}}$ & $0^{\mathrm{a}}$ & 1.08 & $0^{\mathrm{a}}$ \\
\hline $05-34$ & Phoenix & $0^{\mathrm{a}}$ & $0^{\mathrm{a}}$ & $0.00^{\mathrm{b}}$ & $0^{\mathrm{a}}$ \\
\hline \multirow[t]{3}{*}{$05-35$} & Power line & $0^{\mathrm{a}}$ & $0^{\mathrm{a}}$ & 9.48 & $0^{\mathrm{a}}$ \\
\hline & Total ha in 2005 & 0.00 & 0.81 & 16.33 & 0.88 \\
\hline & Grand Total ha 1999- 2005 & 9.08 & 9.32 & 146.08 & 79.47 \\
\hline
\end{tabular}

$0^{\mathrm{a}}=$ Site did not occur in that important habitat category; $0.00^{b}=$ Site was previously disturbed with no new area disturbed. 


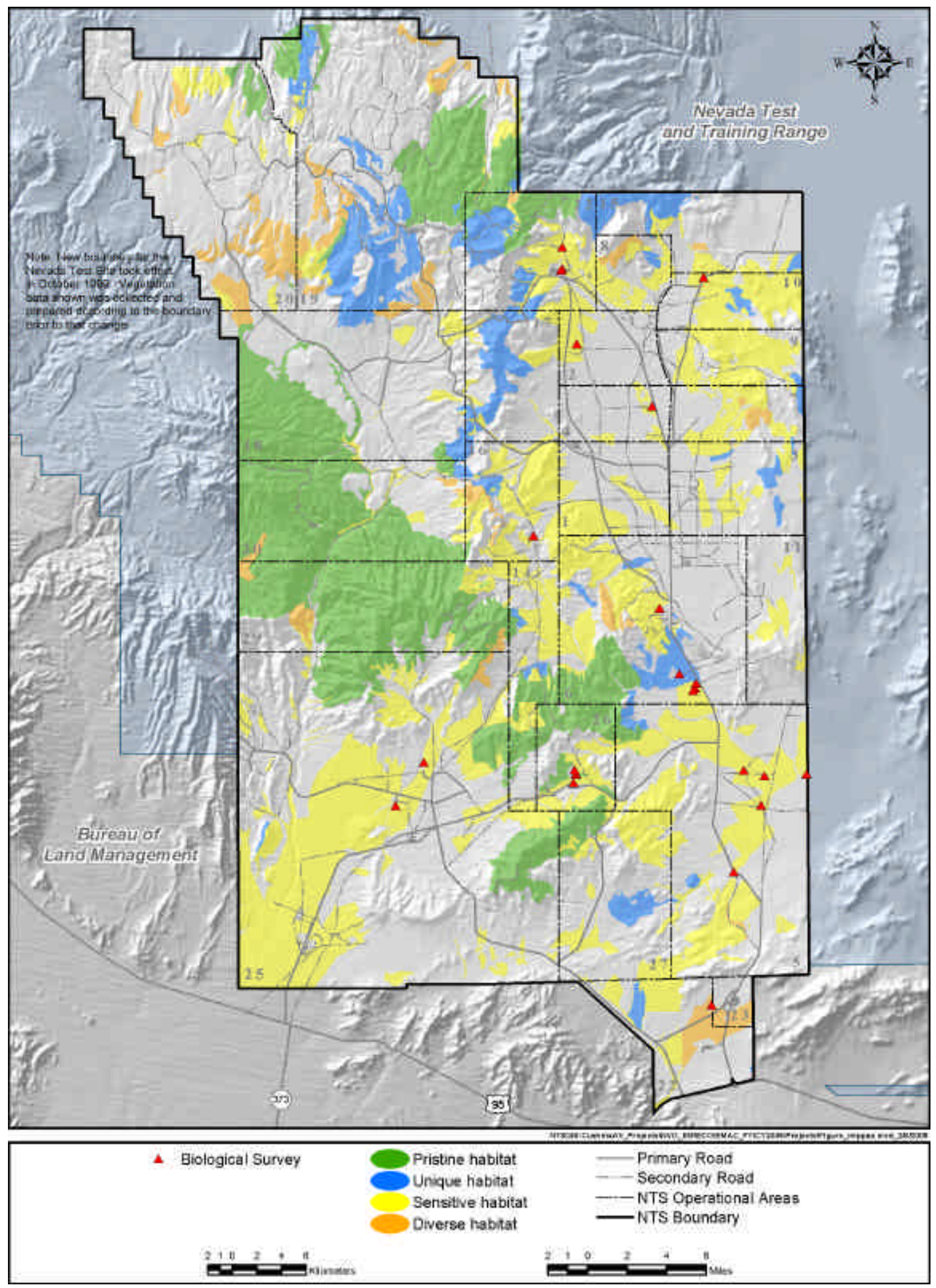

Figure 2-2. Biological surveys conducted in important habitats of the NTS during 2005 


\subsection{DESERT TORTOISE COMPLIANCE}

The desert tortoise occurs within the southern one-third of the NTS. This species is listed as threatened under the Endangered Species Act (ESA). In December 1995, NNSA/NSO completed consultation with the U.S. Fish and Wildlife Service (FWS) concerning the effects of NNSA/NSO activities, as described in the Final Environmental Impact Statement for the Nevada Test Site and Off-Site Locations in the State of Nevada (DOE/NV, 1996), on the desert tortoise. A final Biological Opinion (Opinion) (FWS, 1996) was received from FWS in August 1996. The Opinion concluded that the proposed activities on the NTS were not likely to jeopardize the continued existence of the Mojave population of the species and that no critical habitat would be destroyed or adversely modified. All terms and conditions listed in the Opinion must be followed when activities are conducted within the range of the desert tortoise on the NTS.

The Desert Tortoise Compliance task of EMAC was developed to implement the terms and conditions of the Opinion, to document compliance actions taken by NNSA/NSO, and to assist NNSA/NSO in FWS consultations. The terms and conditions that were implemented by BN staff biologists in CY 2005 included: (a) conducting clearance surveys at project sites within one to seven days from the start of project construction, (b) ensuring that environmental monitors are on-site during heavy equipment operation, and (c) preparing an annual compliance report submitted to the FWS.

\subsection{Project Surveys and Compliance Documentation}

Biologists conducted biological and desert tortoise clearance surveys prior to ground-disturbing activities for 18 proposed projects (27 sites) within the range of desert tortoise on the NTS (Table 3-1, Figure 3-1). Most of these projects were in, or immediately adjacent to, existing facilities and disturbances. These 18 projects do not include the locations of buildings surveyed for bird nests and bat roosts (Project 05-BD) which were within the geographic range of the desert tortoise. No viable tortoise habitat was found at these building sites and their locations are not shown in Figure 2-1.

Only one inactive tortoise burrow was found during tortoise clearance surveys (Table 3-2). This inactive tortoise burrow (Project No. 05-01) was examined with a fiberoptic scope, determined to be empty, and crushed within 24 hours from the start of construction.

Eight projects were initiated that were in previously undisturbed desert tortoise habitat. Project 05-01 disturbed 0.88 ha $(2.18 \mathrm{ac})$ of undisturbed land (Table 3-2). This project is located just west of Mercury in Area 23. Project 05-04 disturbed 3.85 ha $(9.51 \mathrm{ac})$ of undisturbed habitat in northern Frenchman Flat east of Mercury Highway. Project 05-12 disturbed 1.31 ha $(3.24 \mathrm{ac})$ of undisturbed habitat north of CP near the northern limit of desert tortoise distribution on the NTS. Project 05-13 disturbed desert tortoise habitat but a post-activity survey had not been completed by the end of 2005 due to access restrictions to assess the total amount disturbed. The Rad/NucCTEC program in northern Frenchman Flat had four projects (04-41, 05-14, 05-20, and 05-31) that disturbed at least 4.36 ha (10.77 ac). The last project 05-31 is still being constructed so this total will increase and be reported in next years report. BN Ecological Services ensured that on-site construction monitoring was conducted by a designated environmental monitor at all sites where clearance surveys were performed.

Post-activity surveys to quantify the acreage of tortoise habitat actually disturbed were conducted for six projects during this reporting period (Table 3-1). Post-activity surveys were not conducted if the projects were within the tortoise exclusion zone or if viable tortoise habitat was not found within the project area boundaries (due to previous disturbance) during the clearance survey and if the environmental monitor documented that the project stayed within its proposed boundaries. This year, a total of 10.33 ha $(25.53 \mathrm{ac})$ of disturbed tortoise habitat were documented (Table 3-1). 
Table 3-1. Summary of tortoise compliance activities conducted by BN biologists during 2005

\begin{tabular}{|c|c|c|c|}
\hline $\begin{array}{l}\text { Project } \\
\text { Number }\end{array}$ & Project & Compliance Activities & $\begin{array}{c}\text { Tortoise Habitat } \\
\text { Disturbed } \\
\text { ha ( ac) }\end{array}$ \\
\hline $05-01$ & Mercury Landfill Borrow Pit & $\begin{array}{l}100 \% \text {-coverage clearance survey, post- } \\
\text { activity survey }\end{array}$ & $0.88(2.18)$ \\
\hline $05-02$ & CAU 140 (6 CAS sites) & $\begin{array}{l}100 \% \text {-coverage clearance survey, no post- } \\
\text { activity survey* }\end{array}$ & $0(0)$ \\
\hline $05-03$ & CAU 115 Test Cell A & $\begin{array}{l}100 \% \text {-coverage clearance survey, } \\
\text { no post-activity survey necessary* }\end{array}$ & $0(0)$ \\
\hline $05-04$ & Area 6 Waterline & $\begin{array}{l}100 \% \text {-coverage clearance survey, post- } \\
\text { activity survey }\end{array}$ & $3.85(9.51)$ \\
\hline $05-05$ & CAU 165 & $\begin{array}{l}100 \% \text {-coverage clearance survey, no post- } \\
\text { activity survey necessary* }\end{array}$ & $0(0)$ \\
\hline $05-07$ & Mercury Highway Roadside Blading & $\begin{array}{l}100 \% \text {-coverage clearance survey, no post- } \\
\text { activity survey necessary* }\end{array}$ & $0(0)$ \\
\hline $05-11$ & 200 Hill & $\begin{array}{l}100 \% \text {-coverage survey, no post-activity } \\
\text { survey necessary* }\end{array}$ & $0(0)$ \\
\hline $05-12$ & Area 6 Gravel Pit & $\begin{array}{l}100 \% \text {-coverage clearance survey, post- } \\
\text { activity survey }\end{array}$ & $1.31(3.24)$ \\
\hline $05-13$ & ASP & $\begin{array}{l}100 \% \text {-coverage clearance survey, } \\
\text { post-activity survey }\end{array}$ & TBD** \\
\hline $05-14$ & NCCT Trenches & $100 \%$-coverage clearance survey & $0.06(0.15)$ \\
\hline $05-15$ & Area 5 Water Tanks & $\begin{array}{l}100 \% \text {-coverage clearance survey, } \\
\text { no post-activity survey necessary* }\end{array}$ & $0(0)$ \\
\hline $05-16$ & CAU 329 Desert Rock Airport & $\begin{array}{l}100 \% \text {-coverage clearance survey, no post- } \\
\text { activity survey necessary* }\end{array}$ & $0(0)$ \\
\hline $05-20$ & NCCT Facilities & $\begin{array}{l}100 \% \text {-coverage clearance survey Post- } \\
\text { activity survey necessary }\end{array}$ & $4.23(10.45)$ \\
\hline $05-22$ & Fire Station No 1 & $\begin{array}{l}100 \% \text {-coverage clearance survey, post- } \\
\text { activity survey necessary }\end{array}$ & TBD** \\
\hline $05-24$ & CAU 168 (4 sites) & $\begin{array}{l}100 \% \text {-coverage clearance survey, no post- } \\
\text { activity survey necessary* }\end{array}$ & $0(0)$ \\
\hline $05-28$ & CAU 534 & $\begin{array}{l}100 \% \text {-coverage clearance survey, no post- } \\
\text { activity survey necessary* }\end{array}$ & $0(0)$ \\
\hline $05-30$ & $\begin{array}{l}\text { Mercury Highway Roadside Blading } \\
\text { (Frenchman Flats to CP) }\end{array}$ & $\begin{array}{l}100 \% \text {-coverage clearance survey, no post- } \\
\text { activity survey necessary* }\end{array}$ & $0(0)$ \\
\hline \multirow[t]{2}{*}{$05-31$} & NCCT Storm Berm & $\begin{array}{l}100 \% \text {-coverage clearance survey, post- } \\
\text { activity survey necessary }\end{array}$ & TBD** \\
\hline & & Total & $10.33(25.53)$ \\
\hline
\end{tabular}

* Post-activity survey was unnecessary because project was located within previously-disturbed tortoise habitat

$* * \mathrm{TBD}=$ To be determined 


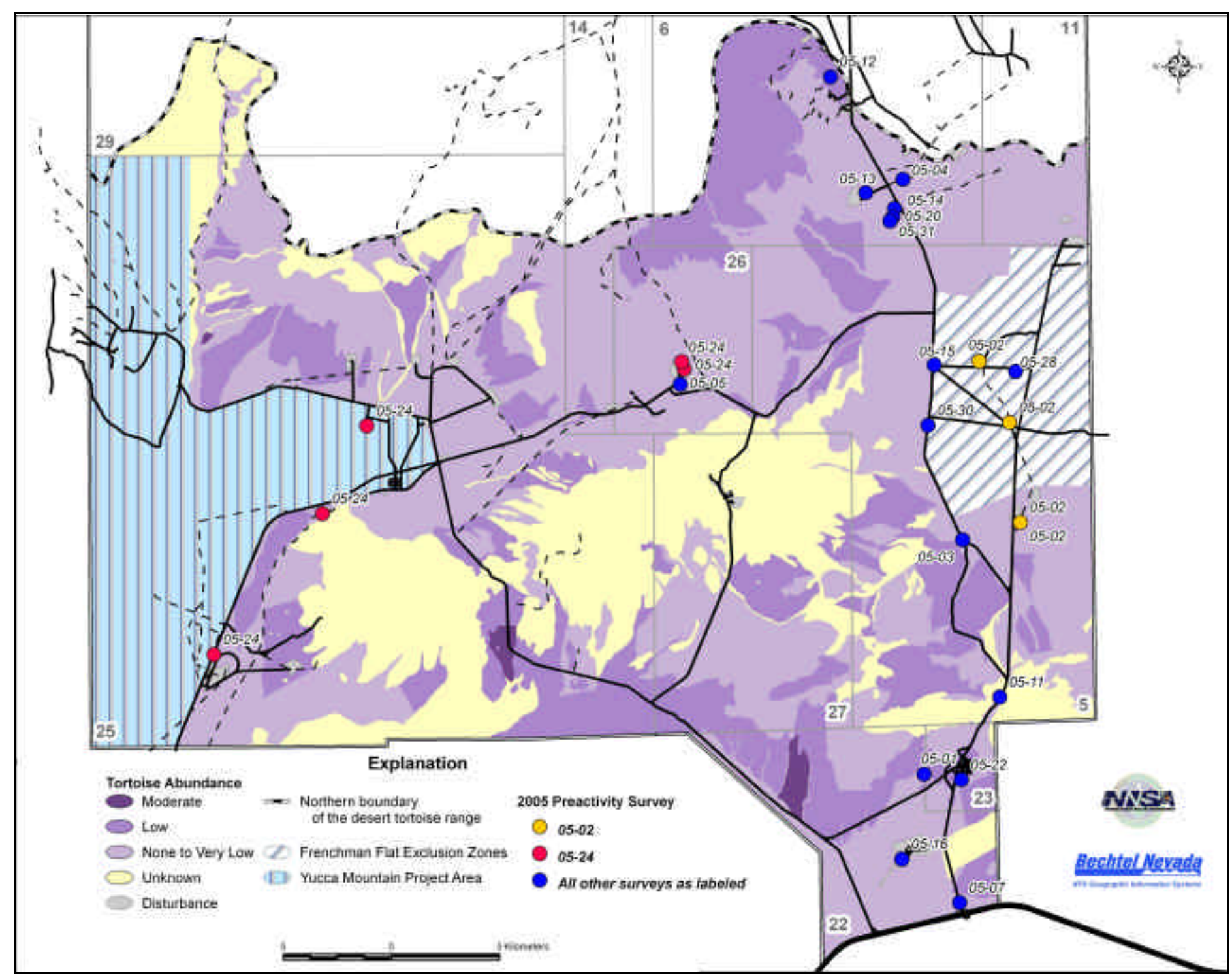

Figure 3-1. Biological surveys conducted in desert tortoise habitat on the NTS in 2005 
In January, BN submitted to NNSA/NSO the annual report that summarized tortoise compliance activities conducted on the NTS from January 1 through December 31, 2005. This report, required under the Opinion, contains: (a) the location and size of land disturbances that occurred within the range of the desert tortoise during the reporting period; (b) the number of desert tortoises injured, killed, or removed from project sites; (c) a map showing the location of all tortoises sighted on or near roads on the NTS; and (d) a summary of construction mitigation and monitoring efforts.

Compliance with the Opinion will ensure that the two goals of the NNSA/NSO's Resource Management Plan (DOE/NV, 1998) are being met; namely, that the desert tortoise is protected on the NTS and that the cumulative impacts on this species are minimized. In the Opinion, the FWS has determined that the "incidental take"1 of tortoises on the NTS and the cumulative acreage of tortoise habitat disturbed on the NTS are parameters to be measured and monitored annually. During this calendar year, the threshold levels established by the FWS for these parameters were not exceeded (Table 3-2). No desert tortoises were accidentally injured or killed, nor were any captured or displaced from project sites. One desert tortoise was killed along roadways within the NTS.

Table 3-2. Parameters and threshold values for desert tortoise monitoring on the NTS

\begin{tabular}{lcll}
\hline \hline \multicolumn{1}{c}{ Monitored Parameter } & $\begin{array}{c}\text { Threshold } \\
\text { Value }\end{array}$ & Adaptive Management Action & $\begin{array}{c}\text { 2005 Value of } \\
\text { Monitored } \\
\text { Parameter }\end{array}$ \\
\hline $\begin{array}{l}\text { Number of tortoises accidentally injured or killed as a } \\
\text { result of NTS activities per year }\end{array}$ & 3 & $\begin{array}{l}\text { Reinitiate consultation with } \\
\text { FWS }\end{array}$ & 0 \\
$\begin{array}{l}\text { Number of tortoises captured and displaced from NTS } \\
\text { project sites per year }\end{array}$ & 10 & $\begin{array}{l}\text { Reinitiate consultation with } \\
\text { FWS }\end{array}$ & $\begin{array}{l}\text { Supplemental employee } \\
\text { education and bulletins }\end{array}$ \\
$\begin{array}{l}\text { Number of tortoises taken in form of injury or mortality } \\
\text { on paved roads on the NTS by vehicles other than those } \\
\text { in use during a project }\end{array}$ & Unlimited & & 1 \\
$\begin{array}{l}\text { Number of total hectares (acres) of desert tortoise habitat } \\
\text { disturbed during NTS project construction since 1992 }\end{array}$ & $\mathbf{1 , 2 2 0} \mathbf{( 3 , 0 1 5 )}$ & $\begin{array}{l}\text { Reinitiate consultation with } \\
\text { FWS }\end{array}$ \\
\hline \hline
\end{tabular}

\subsection{Habitat Revegetation Plan For Loss of Tortoise Habitat}

Mitigation for the loss of tortoise habitat is required under the terms and conditions of the Opinion. The Opinion requires NNSA/NSO to perform either of two mitigation options: (a) pre-pay Clark County $\$ 1,600$ per each hectare ( $\$ 648$ for each acre) of habitat disturbed, or (b) revegetate disturbed habitat following specified criteria. Since 1992, NNSA/NSO has been using the balance of $\$ 81,000$ that NNSA/NSO deposited into a Clark County fund to pre-pay for the future disturbance of 250 acres of tortoise habitat on the NTS. As of December 31, 2005, this fund has used $\$ 79,519$ to compensate for 245.59 acres.

\footnotetext{
${ }^{1}$ To "take" a threatened or endangered species, as defined by the ESA, is to harass, harm, pursue, hunt, shoot, wound, kill, trap, capture or collect, or attempt to engage in any such conduct.
} 
Because only $\$ 1,481$ (less than 5 acres) is available for future compensation, it has been necessary to develop future strategies for funding including implementing habitat mitigation which occurred in 2005 so that work in tortoise habitat may continue without interruption in the future.

BN biologists prepared two site-specific plans to revegetate tortoise habitat as mitigation for two projects. These plans were approved by FWS in December 2005. Work was initiated on these plans and will continue in 2006.

\subsection{Coordination With Other Wildlife Agencies/Biologists}

Three 21-acre circular enclosures in Rock Valley were constructed during 1962-1963 to study the effects of chronic, low-level ionizing radiation on the desert flora and fauna. Over the past decades, at least 24 tortoises have been found, individually marked, and periodically measured. In 2002 there were approximately 18 adult tortoises remaining in the enclosures; however, in 2003, Phil Medica of the U.S. Geological Survey (USGS) Las Vegas Office, BN biologists, and a team of volunteer biologists, found the remains of seven tortoises of known age. Two additional desert tortoises within the enclosures were lost in 2004 presumably to kit fox or coyote predation. These plots were revisited twice in the spring of 2005 with Phil Medica to observe desert tortoises in the fenced plots. Only one desert tortoise was found aboveground; however, no additional carcasses were observed.

Three BN scientists attended training for handling desert tortoises that is given once yearly in Ridgecrest, CA. The entire Ecology staff is now trained to handle desert tortoises.

\subsection{Biological Opinion for Activities at Test Cell C}

In spring of 2005, BN scientists prepared a Biological Assessment of the activities that were being proposed at the Test Cell C (TCC) and reported in an environmental assessment written in 2004. NNSA/NSO requested a Biological Opinion from FWS in April 2005. In June 2005, the FWS rendered an opinion and activities proceeded at TCC in August 2005. As per the opinion the site was surveyed prior to testing to ensure that no tortoises were in the area. It was resurveyed in September, 2005 following the completion of testing to assess any impacts on flora or fauna. More than 25 ha (61.8 ac) were surveyed. No damage to biota was noted during this post activity survey. A final report was written and sent to FWS as required by the Biological Opinion. 
THIS PAGE INTENTIONALLY LEFT BLANK 


\subsection{ECOSYSTEM MAPPING/DATA MANAGEMENT}

Ecological Services began comprehensive mapping of plant communities and wildlife habitat on the NTS in FY 1996. Data were collected describing selected biotic and abiotic habitat features within field mapping units called Ecological Landform Units (ELUs). ELUs are landforms (Peterson, 1981) with similar vegetation, soil types, slope, and hydrology. Boundaries of the ELUs were defined using aerial photographs, satellite imagery, and field confirmation. ELUs are considered by NTS biologists to be the most feasible mapping unit by which sensitive plant and animal habitats can be described. In December 2000, a topical report describing the classification of habitat types on the NTS was published and distributed (Ostler et al., 2000). Ten vegetation alliances and 20 associations were recognized as occurring on the NTS.

In CY 2005 efforts continued to update and improve this habitat data. Efforts were focused on the following tasks in support of ecosystem mapping and data management of all NTS geospatial ecological data:

- Consolidation of data tables into a comprehensive database

- Sampling of selected ELUs for canopy cover data

- Vegetation survey for determining wildland fire hazards

- Coordination with ecosystem management agencies and scientists

\subsection{Consolidation of Data Tables into a Comprehensive Database}

A need was recognized in early 2005 to consolidate vegetation data tables into a comprehensive database that was more user friendly, especially to someone unfamiliar with the many data sets that had been accumulated on the NTS over the years. During 2005 efforts were directed at summarizing and consolidating data sets to provide a simple comprehensive dataset that could be used to share data with biologists from other federal or state agencies, and organizations requiring NTS biological data (e.g., cultural resources specialists desiring ethnobotany information). It was also anticipated that this information could be used to develop a new NTS programmatic environmental impact statement (EIS) or supplement the current 10-year EIS which ends in 2006.

The new Microsoft Access database was developed by running complex queries that combined data from several tables (e.g., physical site data, NAD83 Geographic Information System [GIS] coordinates, site pictures, file names, and biological data). Additionally, the new database was reviewed for completeness and accuracy. New data were supplied where possible by confirming or correcting field data sheets or conducting additional field work. Field headings in the data tables were simplified and described in more detail to improve the quality of the metadata. "Readme" files were written to describe data within subdirectories and data sets. Plant species nomenclature was also reviewed for consistency. The resulting database is simpler, more comprehensive, and facilitates the linkage of this data by GIS software to other spatial data such as digital elevation models (DEM), ELU polygons, and other spatial data (e.g., soils and geology maps).

\subsection{Sampling of Selected ELUs for Canopy Cover Data}

ELUs that were sampled in 1996 did not contain information about shrub canopy cover. Later this parameter was deemed necessary and was added during all subsequent years of field sampling. Also because 1996 was a drought year few annual plant species grew, resulting in a lack of information about canopy cover and annual species. Data collected after 1996 documented shrub canopy cover and had better representation of annual plant species. Photographs taken during 1996 were also substandard. They were made from transparency slides and the color quality of the slide film shifted dramatically 
through the season and during the five years since they were taken. For these reasons, a need was recognized to secure additional photos and data about vegetation on ELUs sampled during 1996 (about 500 sites).

Beginning in 1999, selected ELUs have been revisited as the opportunity presents itself, often during the conduct of other EMAC field activities, to obtain better photographs and vegetation data. During 2005, about 20 ELUs were revisited to collect additional photographs and information. The new photos and data were added and linked to the existing Ecological Geographic Information System (EGIS) database. Canopy cover data were also used to update the vegetation fuels wild land fire hazard assessment for the NTS conducted in 2005.

\subsection{Vegetation Survey for Determining Wildland Fire Hazards}

Wildland fires on the NTS require considerable financial resources for fire suppression and mitigation. For example, costs for fire suppression on or near the NTS can cost as much as $\$ 198$ per ha (\$80 per ac) (estimates by NTS biologists based on actual costs reported in NV-LVD-000029, "Air Force Wildland Fire Incident Report") for suppression of the Air Force Fire, BTH2, which was approximately 8,268 ha [20,430 ac] - June 2005). Additional costs are also incurred for replacement of burned structures. For example, the Egg Point Fire in August 2002 (121 ha [300 ac]) cost well over \$1 million to replace burned power poles, while reclamation of the site cost more than $\$ 200,000$ to stabilize and revegetate.

There has been an average of 11 wildland fires per year on the NTS over the past twenty-eight years with an average of about $218 \mathrm{ha} \mathrm{(88} \mathrm{ac)} \mathrm{per} \mathrm{fire} \mathrm{(Table} \mathrm{4-1).} \mathrm{These} \mathrm{wildland} \mathrm{fires} \mathrm{do} \mathrm{not} \mathrm{occur} \mathrm{randomly}$ across the NTS but occur more often in particular vegetation types that have sufficient fuels (woody and fine-textured fuels) that are conducive to ignition and the spread of wildland fires. Once a site burns it is much more likely to burn again because of invasive annual plants that quickly colonize these areas, unless the areas are revegetated with perennial native species.

The three most commonly observed invasive annual plants to colonize burned areas are Arabian schizmus (Schizmus arabicus), found at low elevations, red brome, found at lower to moderate elevations, and cheat grass (Bromus tectorum), found at moderate to higher elevations. Colonization by invasive species increases the likelihood of future wildland fires because they provide abundant fine fuels that are more closely spaced than native vegetation. Blackbrush (Coleogyne rammosissima) vegetation types appear to be the most vulnerable plant communities to fire followed by pinyon-juniper/sagebrush vegetation types. Wildland fires are costly to control and to mitigate once they occur. Revegetation of severely burned areas is very slow without reseeding or transplanting with native species and other rehabilitation efforts. Untreated areas become much more vulnerable to future fires once invasive species, rather than native species, colonize a burned area.

Beginning in 2004 and in response to DOE O 450.1, surveys were initiated on the NTS to identify wildland fire hazards by conducting a spring (April-May) road survey of vegetation adjacent to 211 sites along major NTS corridors to estimate the abundance of fuels produced by native perennial and annual species and invasive weeds. Information about climate and other wildland fire-related information reported by other government agencies were also identified and summarized as part of the wildland fire hazards assessment. 
Table 4-1. Number and acreage of wildland fires on the NTS.

\begin{tabular}{|c|c|c|c|}
\hline \multicolumn{4}{|c|}{ NTS Wildland Fires } \\
\hline Year & Fires & Hectares & Acres \\
\hline 1978 & 10 & 3,197 & 7,901 \\
\hline 1979 & 6 & 1 & 2 \\
\hline 1980 & 26 & 5,465 & 13,504 \\
\hline 1981 & 13 & 3 & 7 \\
\hline 1982 & 6 & 1 & 2 \\
\hline 1983 & 16 & 7,402 & 18,291 \\
\hline 1984 & 17 & 458 & 1,132 \\
\hline 1985 & 11 & 651 & 1,609 \\
\hline 1986 & 12 & 96 & 236 \\
\hline 1987 & 14 & 86 & 213 \\
\hline 1988 & 23 & 332 & 821 \\
\hline 1989 & 15 & 131 & 323 \\
\hline 1990 & 7 & 3 & 7 \\
\hline 1991 & 4 & 2 & 4 \\
\hline 1992 & 12 & 97 & 239 \\
\hline 1993 & 7 & 3 & 7 \\
\hline 1994 & 8 & 6 & 15 \\
\hline 1995 & 8 & 1,864 & 4,605 \\
\hline 1996 & 2 & 688 & 1,700 \\
\hline 1997 & 6 & 6 & 15 \\
\hline 1998 & 9 & 1,044 & 2,580 \\
\hline 1999 & 7 & 20 & 50 \\
\hline 2000 & 11 & 61 & 151 \\
\hline 2001 & 8 & 198 & 490 \\
\hline 2002 & 7 & 146 & 360 \\
\hline 2003 & 4 & 2 & 4 \\
\hline 2004 & 8 & 3 & 8 \\
\hline 2005 & 31 & 5,261 & 13,000 \\
\hline 28-Year Total & 308 & 27,227 & 67,276 \\
\hline Average Per Year & 11 & 972 & 2,403 \\
\hline Average Per Fire & & 88 & 218 \\
\hline
\end{tabular}




\subsubsection{Survey Methods}

The details of the spring road survey to assess wildland fire hazards on the NTS are described in a 2004 report by Hansen and Ostler (2004). In short, the abundance of fine-textured (grasses and herbs) and coarse-textured (woody) fuels were initially visually estimated on numerical scales ranging from one to five ( $1=$ very low, $2=$ low, $3=$ moderate, $4=$ high, $5=$ =ery high). However, field observations suggested a need to further differentiate subtle differences between fuels at sites with similar ratings. Therefore, each numerical scale was expanded by one-half of a scale value or integer. Additionally, sites where there were no fuels (barren) were rated as 0 (zero). This resulted in the following 10-point potential scale: $0,1,1.5,2,2.5,3,3.5,4,4.5$, and 5. Photographs of sites typifying some of these different scale values are found in Appendix A. The numerical abundance rating for fine fuels at a site was added to the numerical abundance rating of woody fuels at the site to derive a combined fuels rating that ranged from 0 to 10 in one-half integer increments. The index ratings for fuels at these survey sites were then plotted on a map and color coded for severity to indicate the hazards at various locations across the NTS using a Geographic Information System (GIS).

\subsubsection{Survey Results}

Preliminary results of our spring road survey (e.g., maps and narratives), climate information, and wildland fire risk forecasts were reported to the NTS Fire Marshal on June 1, 2005 to assist NTS personnel in planning for the 2005 wildland fire season. The selection of June 1 as a target delivery date was intended to give personnel information needed for planning purposes, in time for the fire season that runs approximately June 1 to October 1 . Transference of data prior to June 1 would not permit vegetation to reach maturity (i.e., maximum fire risk), nor allow time for field data to be properly collected.

Transference of data later than June 1 (e.g., July or August) would not provide sufficient lead time for proper planning and preparation. The time period of June 1 to October 1 represents the hottest and driest period of the year with frequent summer thunderstorms in which the risk of wildland fire is greatest. The preliminary information provided to the Fire Marshal was then summarized and technically reviewed for inclusion in this report for distribution to other interested agencies and organizations.

Climate-Climatic indicators suggested a very high risk of wildland fire hazards. There are seventeen rain gauges on the NTS that are used to measure precipitation. Precipitation during the months of January, February, March, and April are assumed to be most correlated with production of vegetation that produces fine-fuels. The total accumulated precipitation appears to be highly correlated with biomass production during this spring period as reported by Hansen and Ostler (2004). Precipitation measurements at the seventeen rain gauges showed that when precipitation was averaged for all weather stations on the NTS the amount received during the spring of 2005 exceeded the average precipitation by 67 percent (Table 4-2). This increase is substantially more than the 4 percent increase reported by Hansen and Ostler (2004) for this same period in 2004. Some individual weather reporting stations received nearly double the average precipitation during the spring of 2005.

The extended weather forecast for the United States for the summer of 2005 indicated hotter than average temperatures and lower than average precipitation (Figure 4-1). The National Wildland Fire Outlook for the month of June 2005 is shown in Figure 4-2. It identified southern Nevada as having "Crit ical" Fire Potential for the projected period of June 1 to June 30, 2005, the only area in the lower 48 states receiving this designation. 
Table 4-2. Inches of precipitation for meteorological recording stations on the NTS for January through April 2005 compared to long-term averages (AVG).

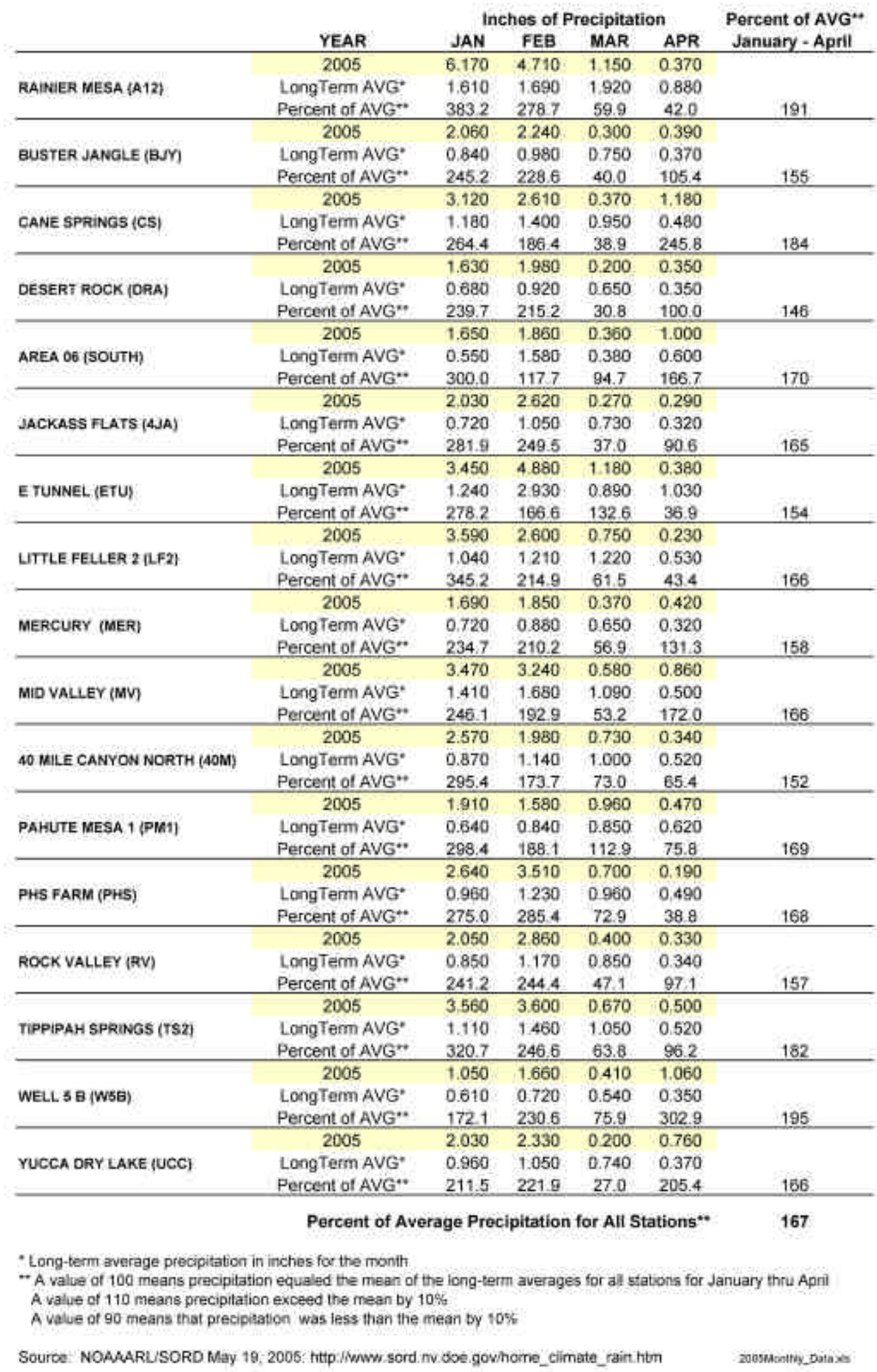



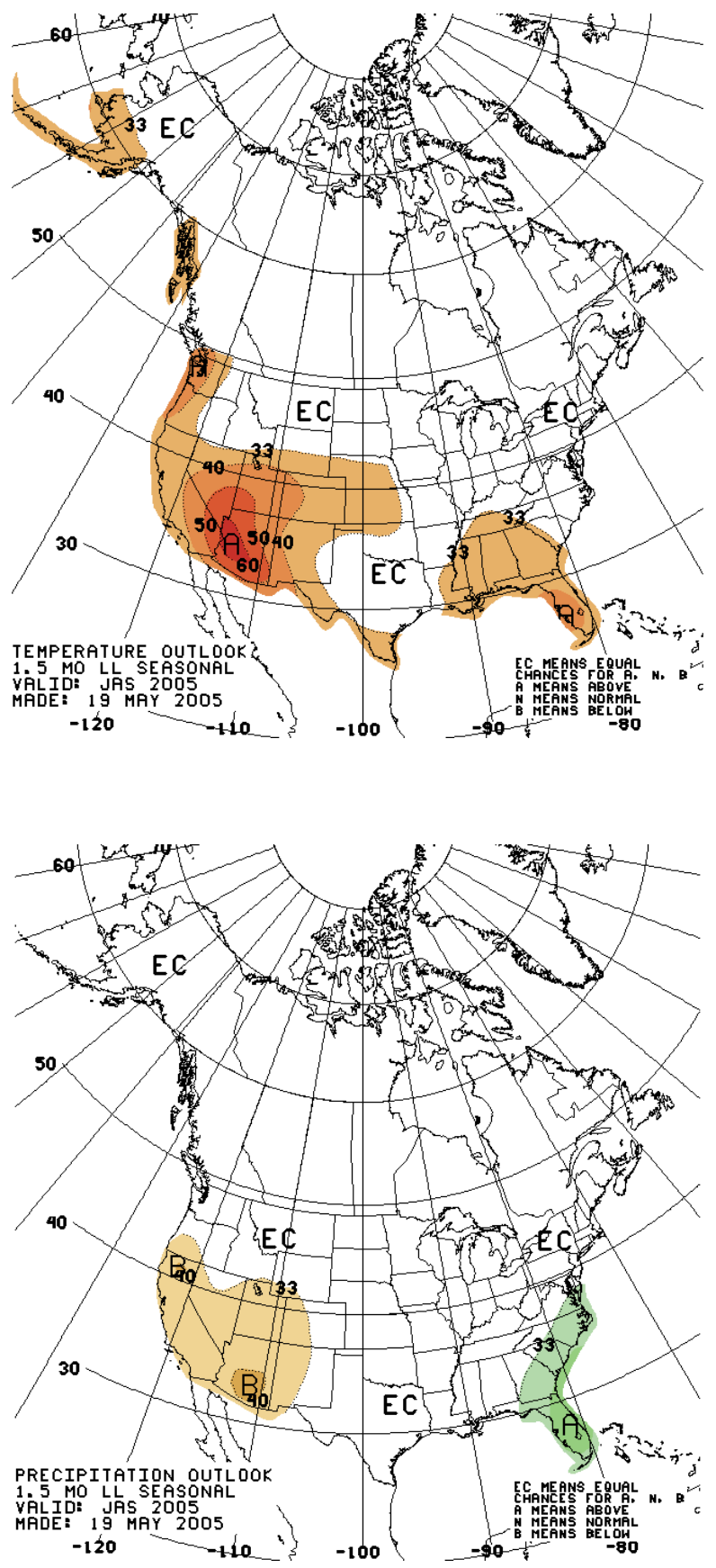

Figure 4-1. Extended weather forecast for July, August, and September of 2005 for temperature and precipitation. (Source of long range forecasts for temperature and precipitation as of May 19, 2005:

http://www.cpc.ncep.noaa.gov/products/predictions/multi_season/13_seasonal_outlooks/color/ $\underline{\text { churchill.html) }}$ 


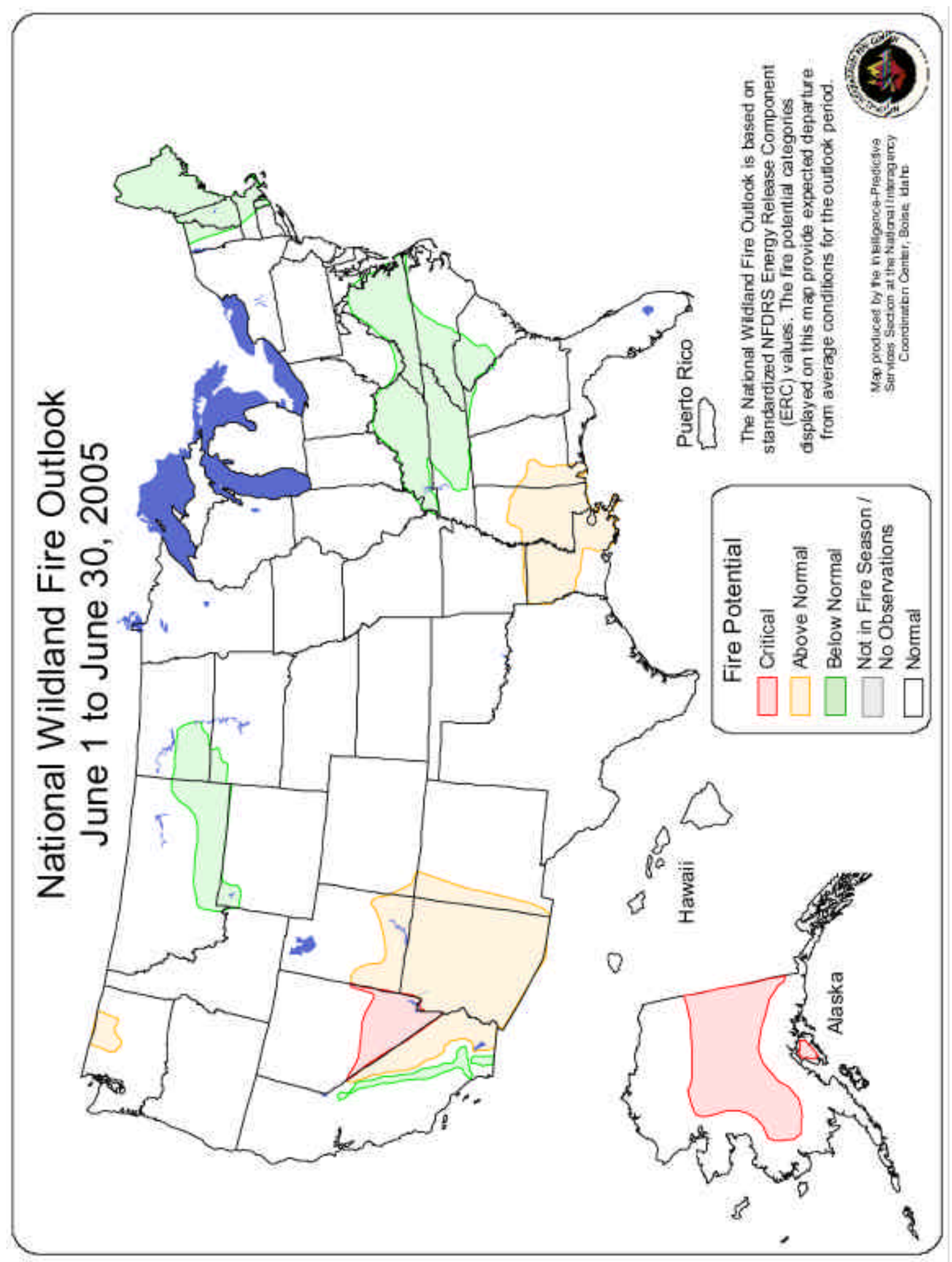

Figure 4-2. National Wildland Fire Outlook, June 1 to June 30, 2005. 
Fuels-Because of the significant increase in spring precipitation in 2005 dramatic increases in fine fuels were observed (Figure 4-3). Increases in woody fuels were not as dramatic (Figure 4-4) as increases in fine fuels at the time of the spring observations because moisture received during the spring had yet to be fully utilized by the deeper-rooted shrubs and trees which continued to grow during the summer months until the soil moisture was depleted in the fall. It is anticipated that woody fuels that resulted from the spring 2005 moisture will be more apparent in the biomass observed during the spring of 2006.

Figure 4-5 shows the combined index values for fine fuels and woody fuels. Highest index values were reported for Fortymile Canyon, Pahute Mesa, and moderate slopes around Yucca Flat. The average combined index values by NTS Operational Area are shown in Table 4-3. Generally, there were increased values in the fine fuel index during 2005. Approximately 7.2 percent of the sampling stations had reduced fine fuels ratings in 2005 compared to 2004 (Table 4-4). Approximately 22.8 percent of the sampling stations had no change in ratings in fine fuels ratings in 2005 compared to 2004, and

approximately 70.2 percent of the sampling stations had increased ratings in fine fuels from 2004 to 2005 .

A general increase, although smaller, was also noted for woody fuels. For example, approximately 2.5 percent of the sampling stations were observed to have declined in index values for woody fuels. This may have been a result of the adverse effects of competition for light from rapidly growing invasive grasses with the low-growing shrubs, or the visibility of the shrub was obscured by the abundance of grasses. Approximately 69 percent of the stations had no change in woody fuels index values from 2004 to 2005 , while there were approximately 28.5 percent of the stations that had an increase in woody fuels index values.

Trends in combined fine fuels and woody fuels index values were similar to fine fuels (Table 4-4). Approximately 7.3 percent of the stations had reductions in index values, 19.4 percent of the stations had no change in ratings, and 73.3 percent of the stations had increases in index values. The average increases in index values across the NTS for fine fuels, woody fuels, and combined index values were $0.71,0.05$ and 0.76 index points respectively from 2004 to 2005 .

There were usually three reasons for a lack of change in index values when comparing values from 2004 to 2005: (a) the site was already rated at a maximum, (b) the site was located on very sandy soils, such as many sites in Jackass Flats, where additional precipitation passed rapidly into the soil profile beyond the reach of surface grasses and herbaceous vegetation, and (c) the site was located on thin, rocky, or old soils with desert pavement that accelerated runoff after precipitation and water was lost to the grasses and herbaceous vegetation.

Examples of the dramatic increase in fine fuels are shown in Figures 4-6 to 4-9.

\subsubsection{Historical Data}

During 2005 data on historical fires on the NTS were obtained (Appendix B). This data describes fires observed from 1978 to 1987, giving size, cause of fire, approximate location, and other notes. This information has been added to the BN Wildlandfire Database. Figure 4-10 shows the extent of fires during 2005 compared to previous areas with evidence of past wildland fires observed on the NTS (Hansen and Ostler, 2004). 


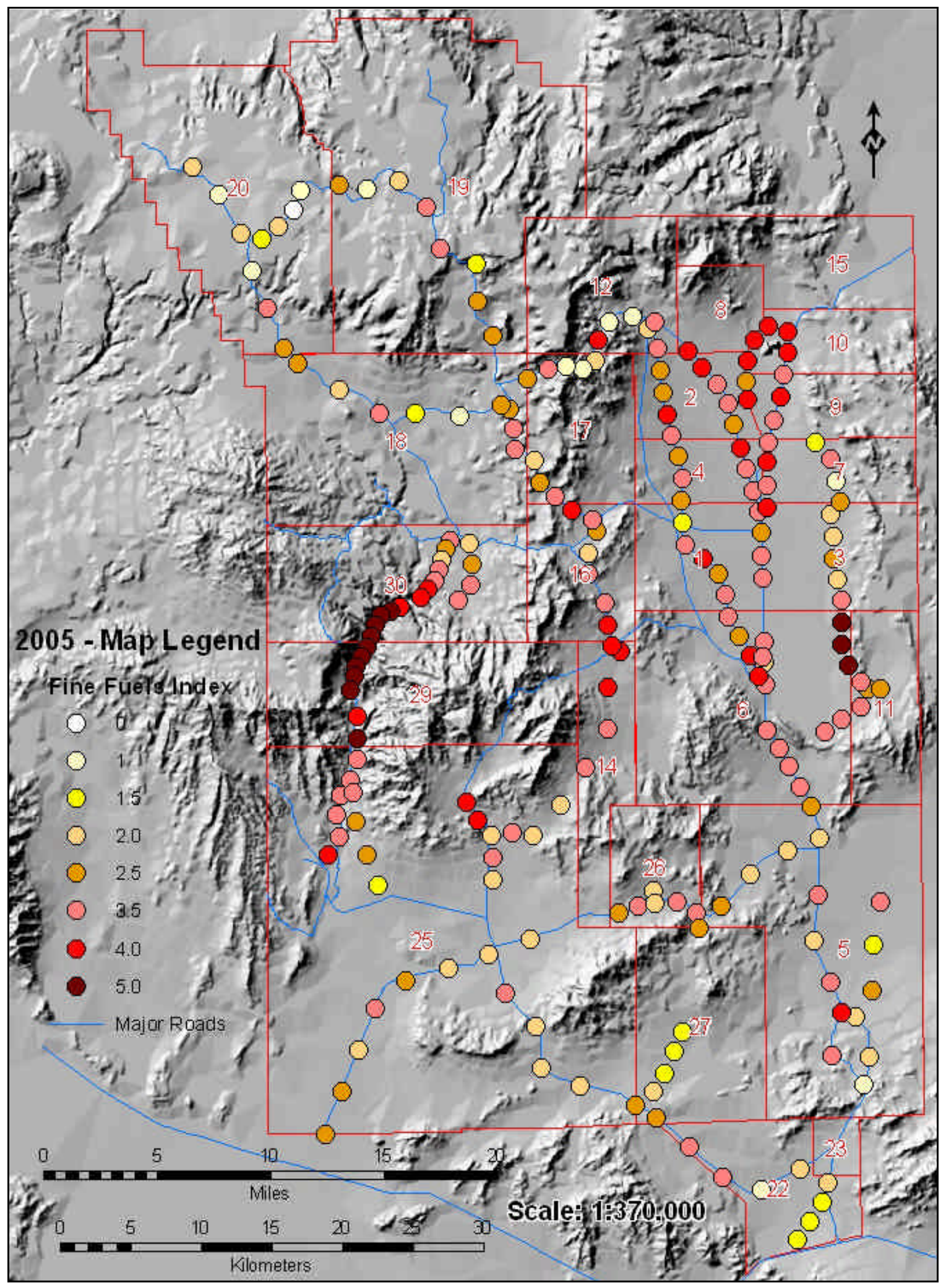

Figure 4-3. Index of fine fuels for 211 survey stations on the NTS by operational area during 2005. 


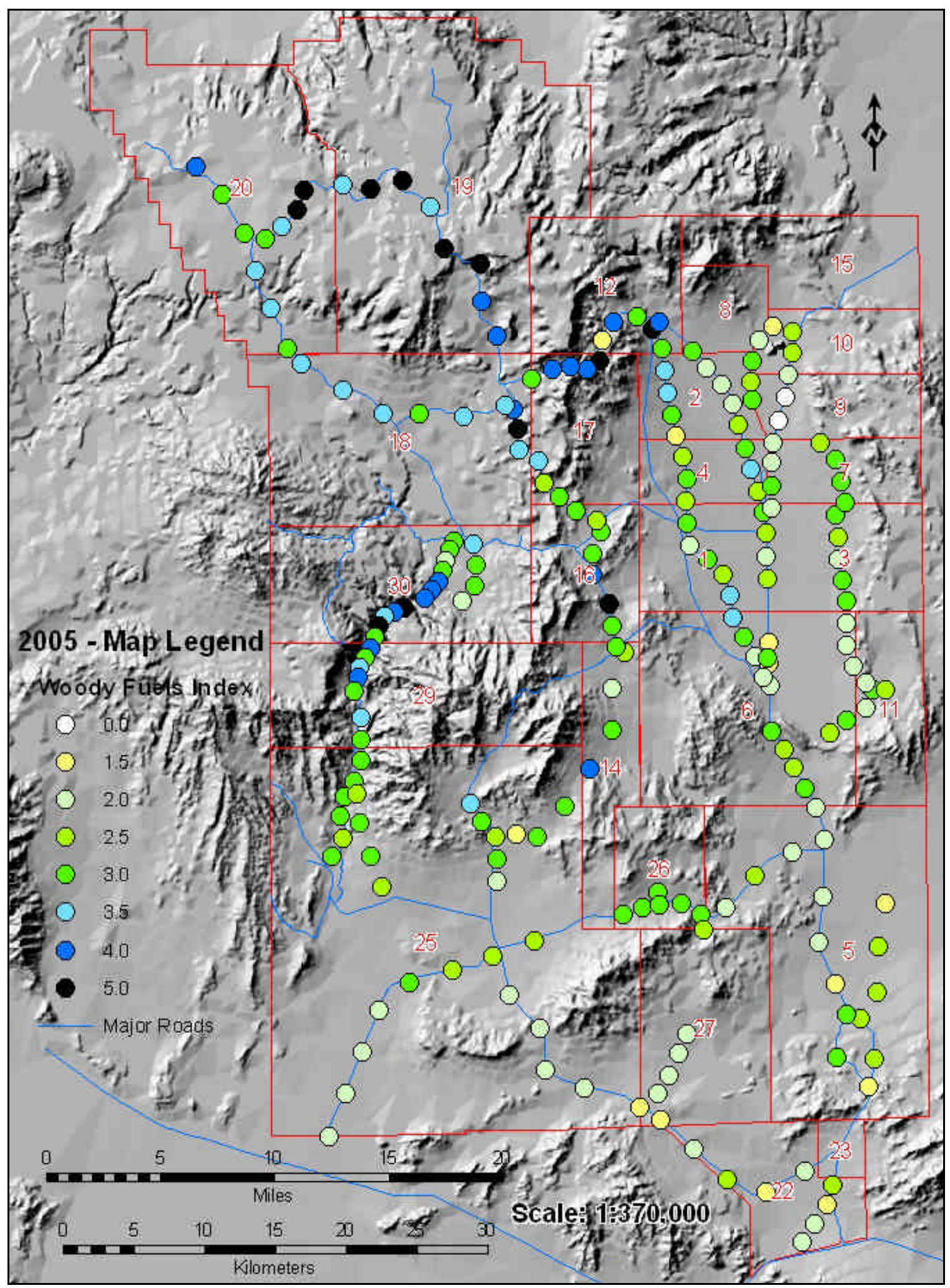

Figure 4-4. Index of woody fuels for 211 survey stations on the NTS by operational area during 2005. 


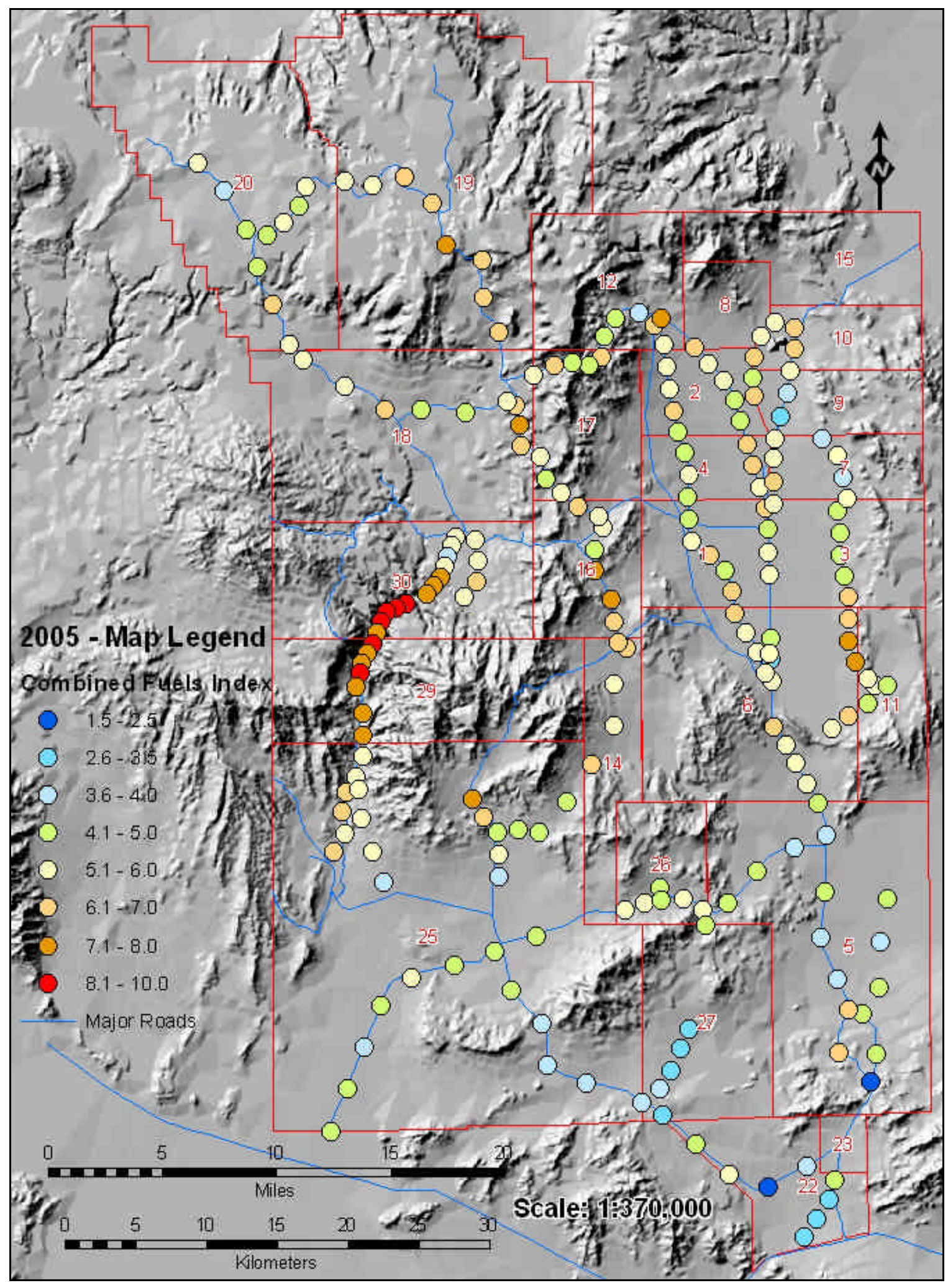

Figure 4-5. Index of combined fine fuels and woody fuels for 211 survey stations on the NTS by operational area during 2005. 
Table 4-3. Average woody and fine fuels combined index values by NTS operating area for 2005 and the average of 2004 and 2005.

\begin{tabular}{|c|c|c|}
\hline \hline \multirow{2}{*}{ NTS Area } & \multicolumn{2}{|c|}{ Year } \\
\cline { 2 - 3 } & $\mathbf{2 0 0 5}$ & $\mathbf{2 0 0 4}$ \& 2005 \\
\hline 29 & 7.86 & 8.04 \\
\hline 8 & 7.00 & 6.25 \\
\hline 30 & 6.94 & 6.86 \\
\hline 19 & 6.54 & 6.50 \\
\hline 14 & 6.50 & 6.20 \\
\hline 16 & 6.43 & 6.18 \\
\hline 10 & 6.17 & 5.96 \\
\hline 4 & 6.00 & 5.29 \\
\hline 18 & 5.94 & 5.58 \\
\hline 6 & 5.88 & 5.24 \\
\hline 1 & 5.72 & 5.00 \\
\hline 17 & 5.69 & 5.47 \\
\hline 2 & 5.69 & 4.94 \\
\hline 12 & 5.67 & 5.33 \\
\hline 26 & 5.50 & 5.11 \\
\hline 7 & 5.36 & 4.68 \\
\hline 3 & 5.25 & 4.92 \\
\hline 11 & 5.25 & 4.44 \\
\hline 20 & 5.20 & 5.23 \\
\hline 25 & 5.19 & 5.02 \\
\hline 9 & 4.88 & 3.81 \\
\hline 5 & 4.56 & 3.98 \\
\hline 22 & 3.88 & 3.53 \\
\hline 27 & 3.60 & 3.20 \\
\hline All Areas & $\mathbf{5 . 6 4}$ & $\mathbf{5 . 2 6}$ \\
\hline \hline
\end{tabular}

Table 4-4. Comparison of fuels rating for NTS sampling stations from 2004 to 2005.

\begin{tabular}{|l|c|c|c|}
\hline \hline & $\begin{array}{c}\text { Fine Fuels Index } \\
\text { (Percent Change) }\end{array}$ & $\begin{array}{c}\text { Woody Fuels Index } \\
\text { (Percent Change) }\end{array}$ & $\begin{array}{c}\text { Combined Index } \\
\text { (Percent Change) }\end{array}$ \\
\hline Stations with Reduced Ratings & 7.2 & 2.5 & 7.3 \\
$\begin{array}{l}\text { Stations with No Change in } \\
\text { Ratings }\end{array}$ & 22.8 & 69.0 & 19.4 \\
$\begin{array}{l}\text { Stations with Increased Ratings } \\
\text { Average Point Increase per } \\
\text { Station }\end{array}$ & 70.2 & 28.5 & 73.3 \\
\hline \hline
\end{tabular}




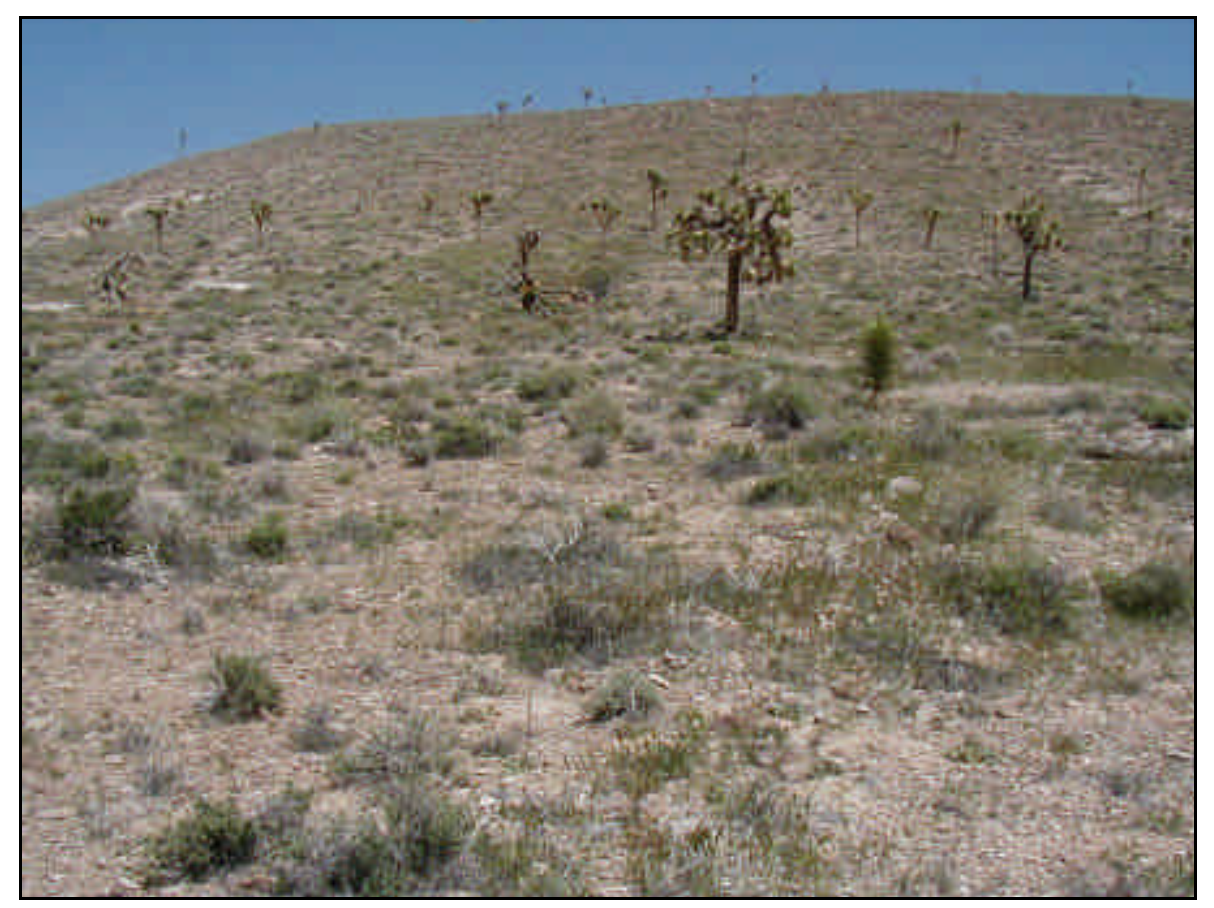

Figure 4-6. Site 83 on the east side of Yucca Flat in 2004. (Photo taken by W. Kent Ostler on April 26, 2004.)

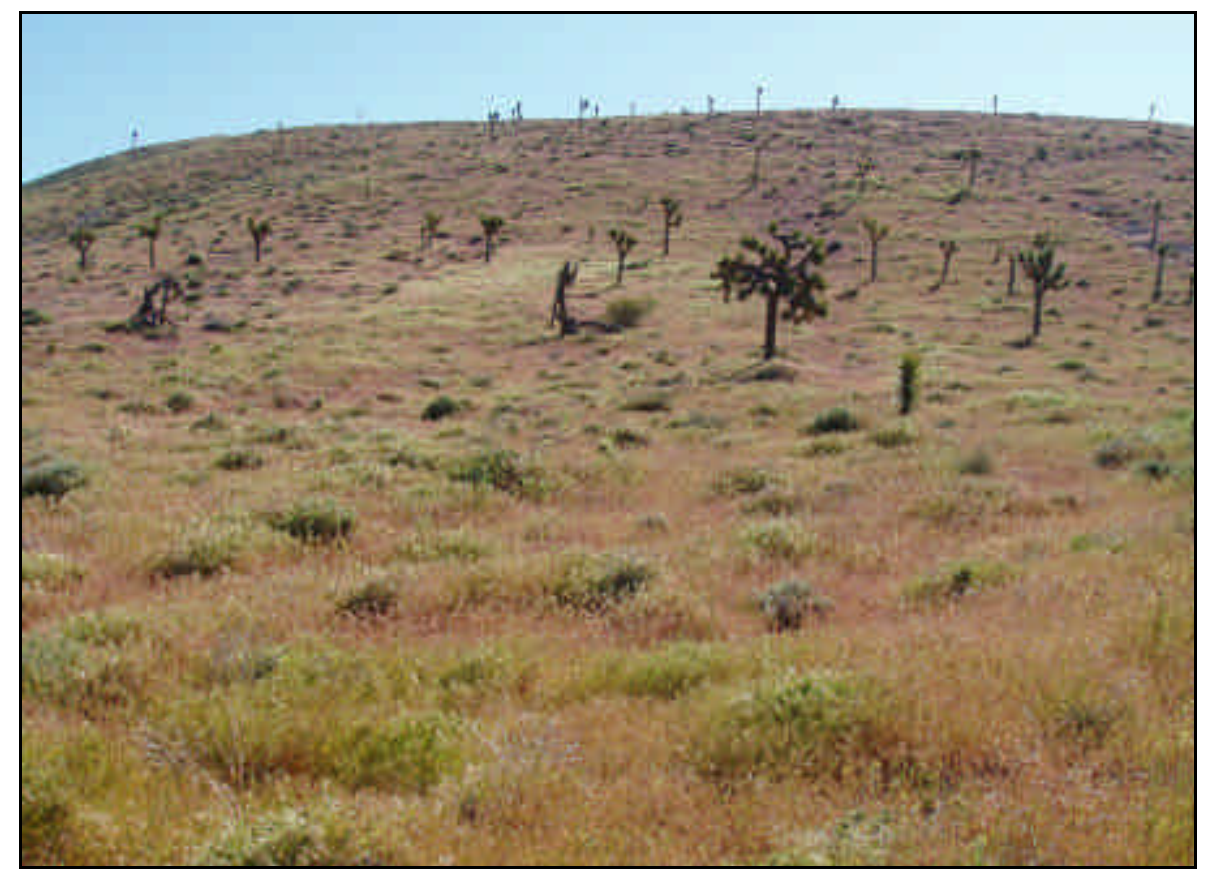

Figure 4-7. Site 83 on the east side of Yucca Flat in 2005. (Photo taken by W. Kent Ostler on April 20, 2005.) 


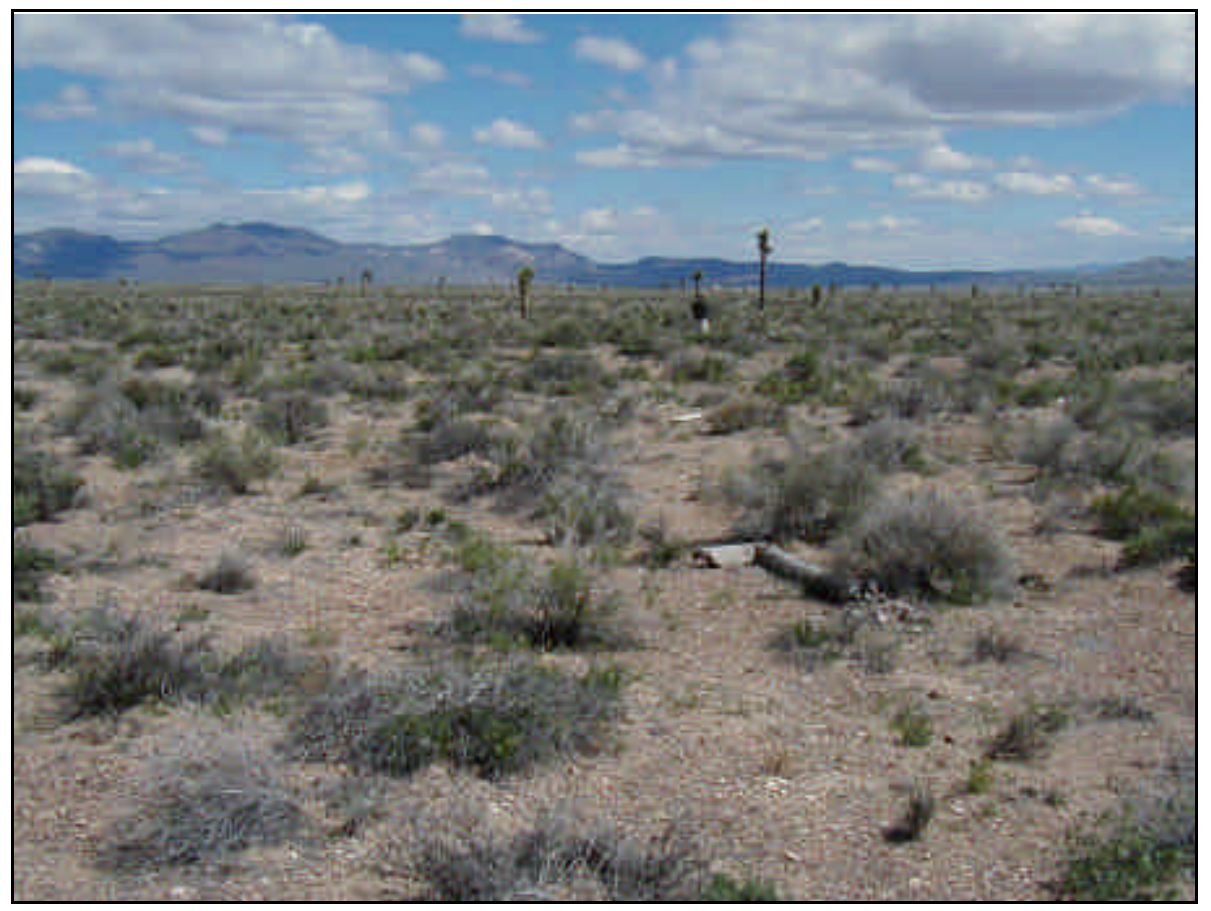

Figure 4-8. Site 99 on the west side of Yucca Flat in 2004. (Photo taken by W. Kent Ostler on April 29, 2004.)

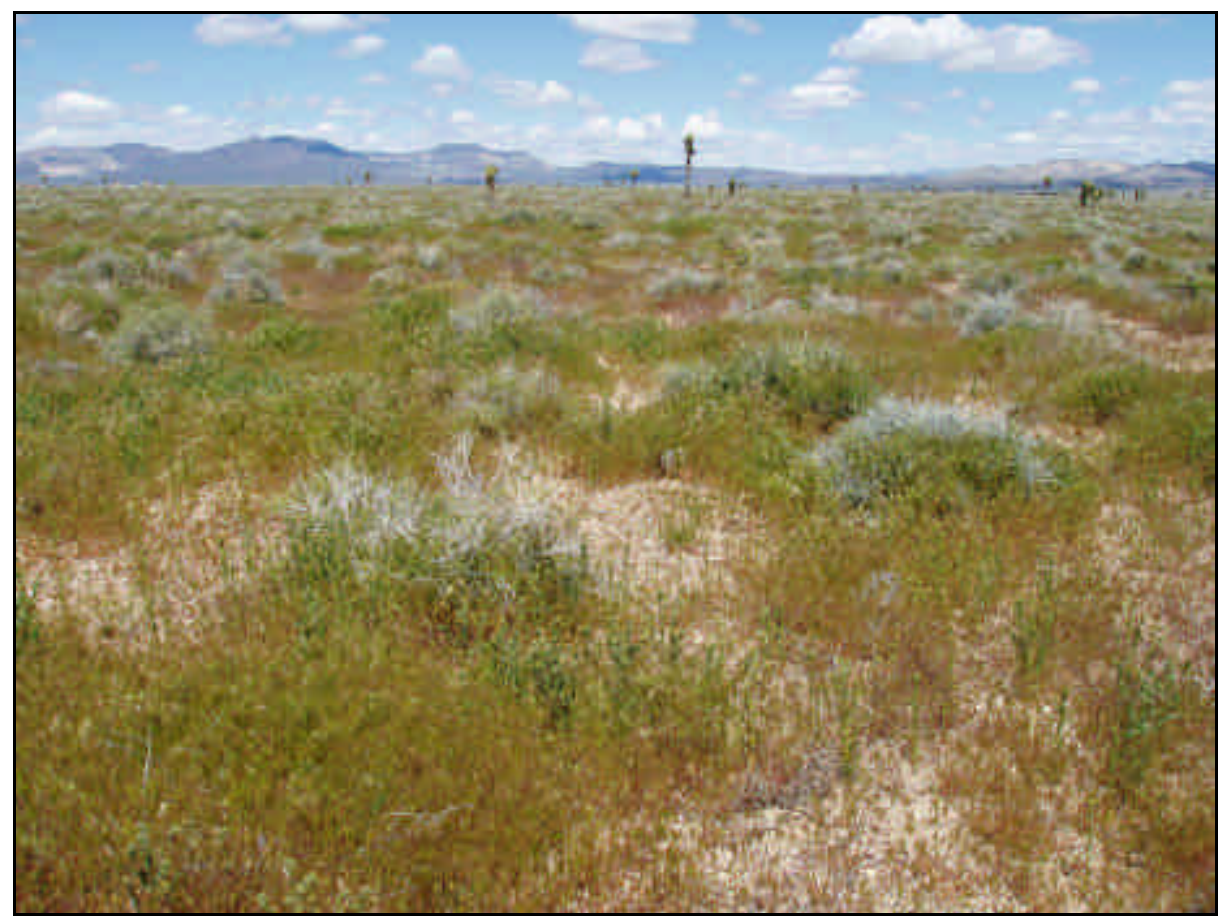

Figure 4-9. Site 99 on the west side of Yucca Flat in 2005. (Photo taken by W. Kent Ostler on April 20, 2005.) 


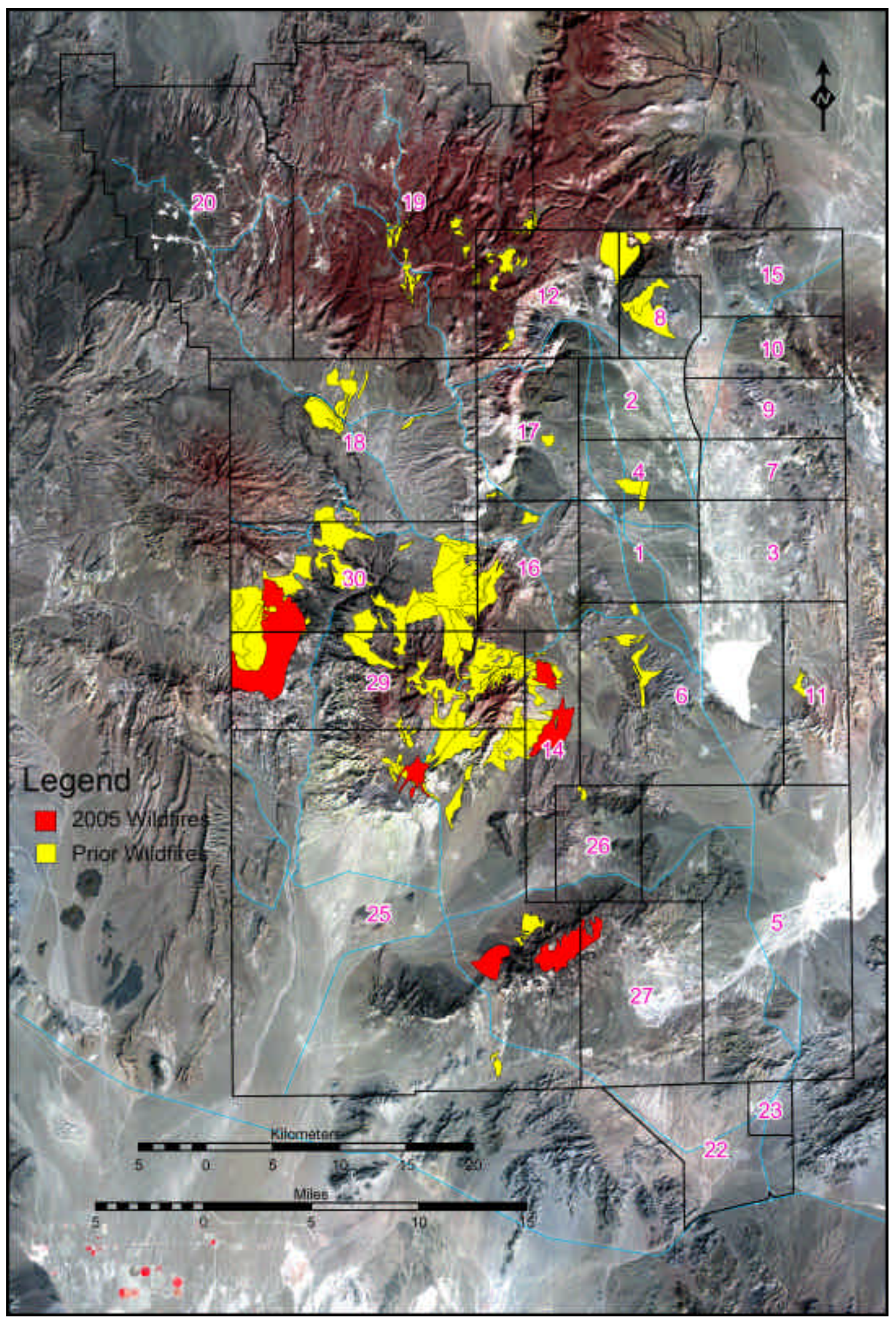

Figure 4-10. Location of wildland fires on the NTS. 


\subsection{Coordination with Ecosystem Management Agencies and Scientists}

BN biologists interfaced with other ecosystem management agencies and scientists in 2005 for the following activities:

- Accompanied scientists from US Forest Service (USFS) who are conducting forest inventories throughout the United States. One site was visited and sampled on Rainier Mesa on August 10, 2005. BN provided USFS scientists with transportation to the site and observed their activities to ensure they complied with NNSA and NTS rules and safety regulations.

- Participated in two emergency stabilization planning meeting with Bureau of Land Management, FWS, Nevada Division of Wildlife, and US Geological Services (USGS) personnel assessing impacts of the large wildfires in southern Nevada and developing emergency stabilization plans for controlling erosion from these sites. Provided presentations on revegetation in Mojave Desert including techniques, species selection, timing, and irrigation. Meetings were held on July 5 at FWS offices in Las Vegas and on July 15th in Mesquite.

- Provided a paper for publication from a presentation given at the Mojave Desert Science Symposium in Redlands, California in November, 2004.

- Communication with the USGS personnel regarding the burning by wildland fires of two historical plots established by Janice Beatley on the NTS in the 1970s and currently being monitored by the USGS. These sites were revisited and resampled in 2005 by the USGS, located in Tucson, Arizona.

- Coordination with scientists from Neptune and Company, Inc., of Los Alamos, New Mexico for various aspects of their field research which involves characterizing the potential biointrusion of ants and termites into buried waste. 


\subsection{SENSITIVE AND PROTECTED/REGULATEDSPECIES AND HABITAT MONITORING}

There are 19 plants and 27 animals which occur on the NTS that are considered sensitive because they occur on the NNHP sensitive species list or have a high or moderate risk rating in the Nevada Bat Conservation Plan Bat Species Risk Assessment. An additional 14 mammals and over 240 birds are protected or regulated by state and federal regulations. These include the desert tortoise which is listed as a threatened species under the ESA. EMAC tasks related to the desert tortoise are addressed in Section 3.0 of this report. The goal of monitoring these species is to ensure the continued presence of all sensitive and protected/regulated plants and animals on the NTS by protecting them from significant impacts due to NNSA/NSO actions. A secondary goal is to gather sufficient information on these species' distribution and abundance on the NTS to determine their status and if further protection or management under state or federal law is necessary. Natural and man-made water sources on the NTS are rare and unique habitats which are also routinely monitored to assess their status and use by wildlife.

\subsection{Sensitive Plant Species}

In 1998, NNSA/NSO prepared a Resource Management Plan (RMP) with an objective to protect and conserve sensitive plant species found on the NTS and to minimize cumulative impacts to those species as a result of DOE activities (DOE/NV, 1998). Pursuant to that document, BN published and distributed an Adaptive Management Plan for Sensitive Plant Species on the Nevada Test Site (BN, 2001). This document presents the procedures designed to ensure that the RMP goals are met by identifying parameters to be measured during long-term vegetation monitoring and outlining management actions that may be taken if significant threats to sensitive species are detected.

\subsubsection{Revised List of Sensitive Plant Species for the NTS}

In the Adaptive Management Plan (BN, 2001) it is recommended that plant species found on the NTS that may require protection because of such factors as rarity, susceptibility to disturbance, or ecological or economic importance, be identified. Other agencies are consulted in determining which species should be protected. Under the NNHP, the Nevada Department of Conservation and Natural Resources maintains a detailed list of rare vascular and non-vascular plants, which includes plants protected by federal agencies, the Division of Forestry of the State of Nevada, and the Nevada Native Plant Society (NNPS). Any species included on the NNHP list of rare plant taxa and are known or suspected to occur on the NTS are included in the list of sensitive plant species for the NTS (see Table 2-1, shown previously).

The list of sensitive plant species for the NTS was reviewed in 2005. No additions or deletions to the list are recommended. There are no plant species known to occur on the NTS that are listed federally by the FWS as endangered or threatened or by the State of Nevada as critically endangered. Currently there are 18 vascular plant species and one non-vascular plant species that are listed as rare plant taxa by the NNHP (see Table 2-1, shown previously) and are known to occur on the NTS.

\subsubsection{Long-term Vegetation Monitoring}

The goal of long-term vegetation monitoring is to maintain an accurate assessment of the distribution of sensitive plant species on the NTS and to periodically evaluate the status of these species. In an effort to maximize monitoring efforts the 19 sensitive plant species on the NTS have been assigned to one of three levels of monitoring: (a) those species that are actively monitored, (b) those not monitored, or (c) those species to be evaluated (Table 2-1 shown previously). Species actively monitored are those known to 
occur on the NTS, are on the NNHP list of sensitive plant species, and have limited distribution either on the NTS or over its entire range. Species not monitored are termed "inactive" (see Table 2-1, shown previously) and are thus not included in the long-term monitoring plan for NTS plant species. They include species that are known to occur on the NTS and for which there is sufficient information to suggest that their distribution is widespread enough on the NTS, in Nevada, or over their entire population range that protective actions are not needed. Their presence at proposed project sites is still documented during biological surveys and impacts to the species avoided when possible. This category may also include those species for which there is a question regarding their status. For example, the nomenclature of one species has been synonymized with another species which is widespread and unlisted. However several regional botanists don't agree with the synonymy and until this issue is resolved the species will be maintained on the NTS list of rare species but will not be actively monitored. Species to be "evaluated" (see Table 2-1, shown previously) are those for which there is insufficient information to determine if they occur on the NTS or if they do occur whether their distribution and/or abundance is threatened and warrants protection and monitoring.

The list of sensitive plant species on the NTS (see Table 2-1, shown previously) includes nine species to be actively monitored and ten that are maintained on the list but are not actively monitored. Two of the nine species that will be monitored are annual forbs, five are perennial forbs, one a perennial shrub, and the final species is a bryophyte (moss).

Field monitoring to assess population status is conducted for each "active" species at least once every five years. A minimum of two species are selected each year and a representative number of populations are monitored. For most of the sensitive species population locations and habitat descriptions have been recorded during previous field studies (Blomquist et al., 1992, Blomquist et al., 1995). Other data will be collected during field monitoring to ascertain the current status of the species and may include density of plants, signs of herbivory, disease, or evidence of direct or indirect disturbance to its habitat.

Two species were monitored in 2005: Astragalus beatleyae (Beatley's milkvetch) and Astragalus funereus (black woolypod) (Figure 5-1). In addition evaluation surveys were conducted for Entosthodon planoconvexus (Planoconvexus entosthodon), a non-vascular plant. 


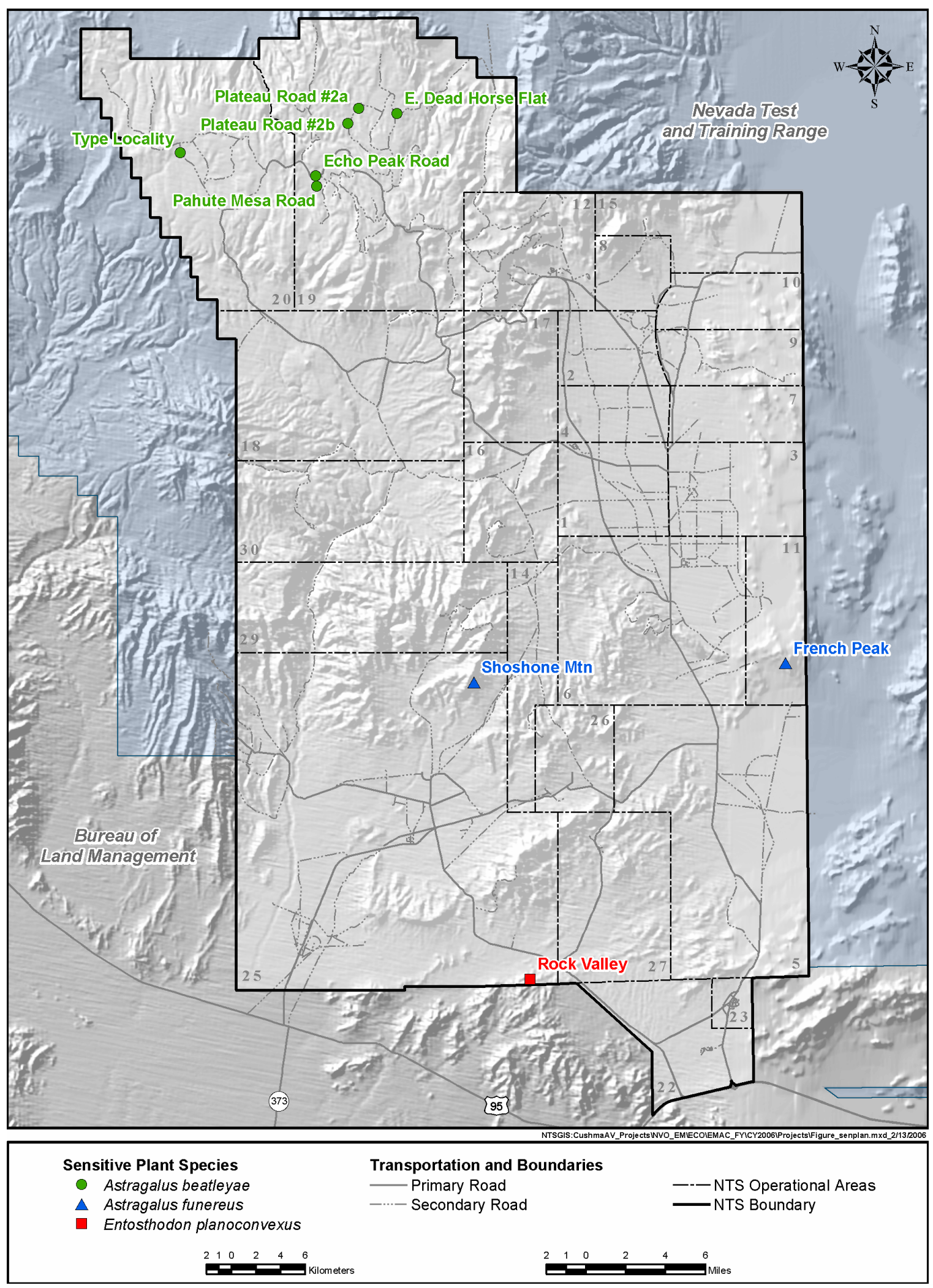

Figure 5-1. Location of sensitive plant populations monitored on the NTS during 2005. 


\subsubsection{Astragalus beatleyae}

A. beatleyae was first collected on the NTS in 1968 and later named (Barneby, 1970). Because of its limited distribution it was considered for listing as an endangered species under the Endangered Species Act in 1975. In the early 1980's the species was listed as a Category 1 species, which means there was sufficient information to list it either as an endangered or threatened plant. Conservation agreements followed the proposed listings which prompted more intensive studies on habitat requirements, life history and distribution. By 1991, 18 populations of A. beatleyae had been located; 14 on the NTS and four on adjacent Air Force lands. Results of these studies were published (Blomquist et al., 1992) and from them it was determined that A. beatleyae was more abundant or widespread than previously believed and not subject to any identifiable threats thus failing to meet listing criteria defined in the Endangered Species Act. A. beatleyae was no longer considered for listing by the FWS and in 1999 the NNHP recommended that it no longer required state protection (Nevada Rare Plant Workshop minutes, 1999). It is now included on their "Watch" list of Rare Plants for the State of Nevada.

Although not protected by federal or state legislation A. beatleyae is still monitored on the NTS. It was not listed by Federal or State agencies because there were no "identifiable threats" to the species. Monitoring continues to assess the current status of the species and documents any changes since initial studies were completed in 1992. Under the Adaptive Management Plan field surveys were conducted for A. beatleyae in 2002. All 14 of the populations located on the NTS were revisited and plant density recorded at some of the sites. Plant densities were much lower in 2002 than they were from 1989 through 1991, possibly due to the very dry conditions over the last several years. The effect of the drought on the density of A. beatleyae and the increased activity on the NTS in areas where this species is known to occur, prompted additional surveys in 2005, a year with above normal rainfall. Six of the 14 populations on the NTS were selected and surveyed in 2005. A representative number of the permanent transects established at each site during earlier studies were sampled. Monitoring was completed in May and June when plants were in flower and setting seed.

The density of $A$. beatleyae averaged over the six sites that were sampled this year was $0.30 \mathrm{plants} / \mathrm{m}^{2}$ in $1989,0.40$ plants $/ \mathrm{m}^{2}$ in 1990, 0.73 plants $/ \mathrm{m}^{2}$ in $1991,0.05 \mathrm{plants} / \mathrm{m}^{2}$ in 2002 and $0.67 \mathrm{plants} / \mathrm{m}^{2}$ in 2005. Plant densit ies this year were about what it was in 1991 but higher than all other years. Monitoring in future years will occur during years when sufficient moisture is received for plant growth. Natural fluctuations in population densities can be expected and monitoring over the years will provide a better estimate of the variation of plant density.

The results of this year's monitoring were higher than the results of 2002. At the type locality (Figure 5-2) and E. Dead Horse Flat sites density estimates were higher than original estimates. 


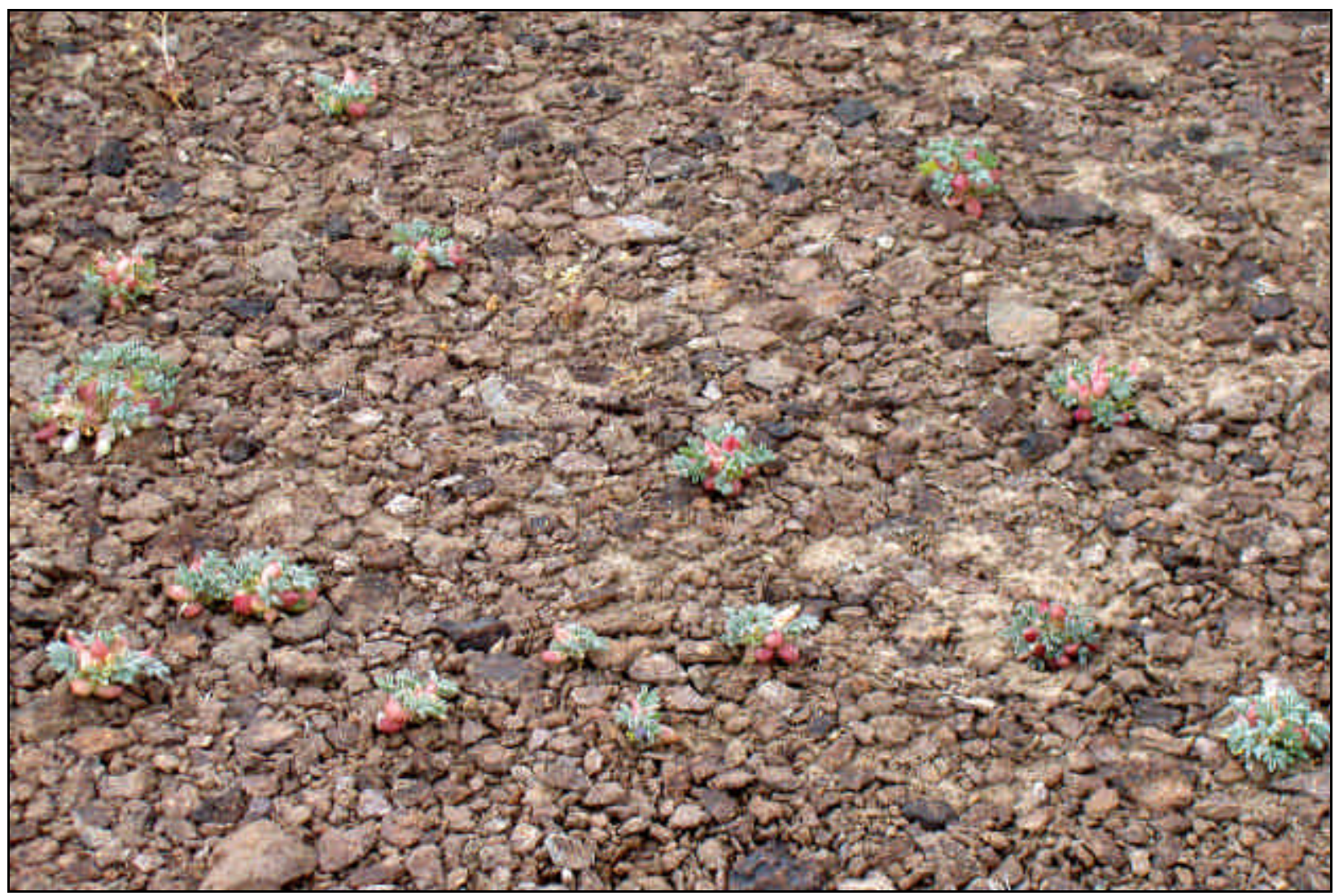

Figure 5-2. The density of $A$. beatleyae at the type locality was higher this year than it has ever been. (Photo by David Anderson, June 2005)

At the two sites along Plateau road estimates were within the range of variation of the density measure between 1989 and 1991. Only at the Pahute Mesa Road and Echo Peak Road sites were estimates still lower than the original estimates (Figure 5-3). The Echo Peak Road site was significantly higher than 2002 estimates, but still slightly below estimates made from 1989 to 1991. Of moderate concern is the low density recorded at the Pahute Mesa Road site. This site may be monitored more frequently to better evaluate the status of A. beatleyae and determine if there is something causing the lower density. There is no appearance of disturbance at the site. The site is close to a major road but there is no vehicular access to the site. Quantitative measurements were only taken on the permanent transects, however the entire site was surveyed and very few individuals of $A$. beatleyae were found. 


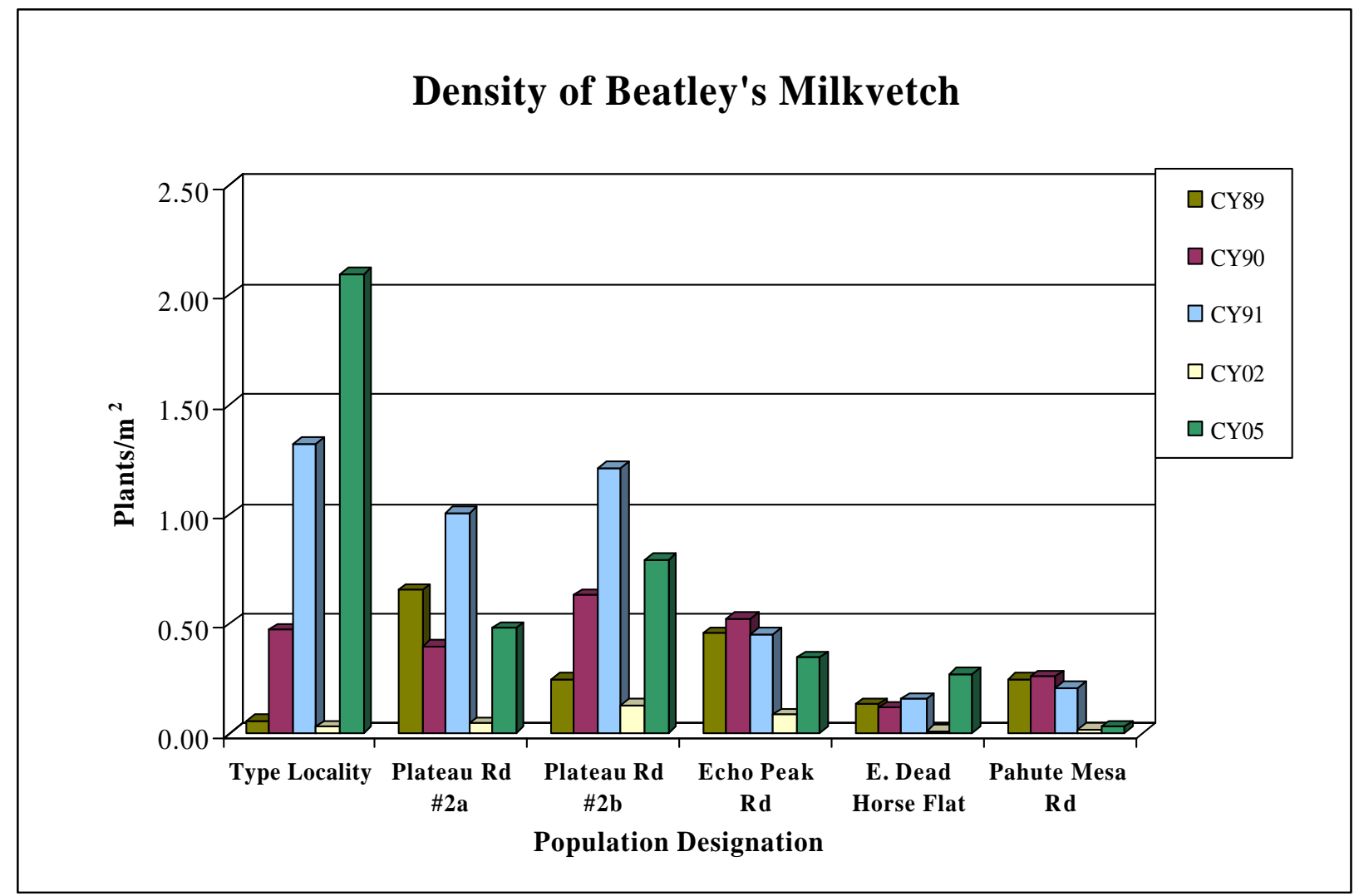

Figure 5-3. Density of $A$. beatleyae over the last 15 years at six of the 14 populations found on the NTS.

\subsubsection{Astragalus funereus}

A. funereus is known from two locations on the NTS; one on the southern slopes of French Peak and one on the eastern slopes of Shoshone Mountain (see Figure 5-1, shown previously). Overall distribution extends west around Beatty and into Death Valley National Park. The majority (nearly 70 percent) of the area occupied by A. funereus is on the NTS (Blomquist et al. 1995). Currently it is not being considered for listing by the FWS under the Endangered Species Act guidelines, nor is it proposed to be listed by the State of Nevada. It is included on the "Watch list" in the Nevada List of Rare Plants, which is maintained by the NNHP.

Monitoring A. funereus populations on the NTS under the auspices of the Adaptative Management Plan for Sensitive Plant Species (BN, 2001) began in 2002 and continued in 2003 and 2005. The objective was to evaluate the status of the species by confirming its presence and estimating the abundance of the species. Surveys conducted in 2002 were unproductive mainly because of poor growing conditions. The French Peak area was opportunistically surveyed during surveys for Phacelia beatleyae with no results. The eastern slopes of Shoshone Mountain were also surveyed where one individual plant was located. The western slopes of Shoshone Mountain were intensively surveyed but no plants were found. The 
surveys were repeated in 2003 and again focused on the western slopes of Shoshone Mountain where large populations of the species had been reported in the early 1990s. Survey results in 2003 were the same as in 2002.

In 2005, the first year with above average precipitation in several years, monitoring for $A$. funereus again focused on the southern slopes of French Peak, southeastern slopes of Shoshone Mountain, and the western slopes of Shoshone Mountain. A known population of A. funereus in the Beatty Wash area west of the NTS was visited to determine its response to the favorable growing conditions in 2005. Numerous plants were found at the site in full flower and setting seed. Monitoring efforts then began on the NTS, starting on the southern slopes of French Peak then the eastern and western slope of Shoshone Mountain.

About 240 plants were found at the French Peak population in June 2005. Estimates in previous years ranged from 170 to 287 (Blomquist et al. 1995). No quantitative data was recorded in previous years nor was it taken in 2005. Plants, as reported previously, are commonly found on steep slopes in very loose, unstable volcanic tuff (Figure 5-4).

The other population of $A$. funereus surveyed was on the eastern slopes of Shoshone Mountain. Plant surveys in 1991 and 1992 at this location reported around 30 individuals. In 2005 there were about 20 plants. The habitat at this location is characterized by more vascular plants but soils were the same volcanic tuff.

A couple of survey days were spent on the western slope of Shoshone Mountain. As in years past no individuals of A. funereus were found. Typical habitat for the species is uncommon on the western slopes. A different species of Astragalus was occasionally encountered but no individuals of $A$. funereus were found. Based on the results of the surveys conducted in this area over the last 3 years it was determined that reports of A. funereus on the western slopes of Shoshone Mountain were in error and this population will be reclassified as potential habitat and will not be part of the monitoring program. In the event $A$. funereus is found at this location it will be re-included in the monitoring program.

Comparisons of densities or abundance of plants from year to year is misleading because the areas sampled are without boundaries and therefore the data unquantifiable. Prior to monitoring A. funereus in the future permanent plots will be established at two or three sites and densities will be estimated within each plot. This methodology will facilitate comparisons between years and provide a more accurate assessment of species status changes from year to year. In addition sites off the NTS may be selected to serve as control sites. The two locations on the NTS represent less than half of the total number of sites and monitoring other sites will provide more comprehensive reference data for this species.

The sites that were successfully monitored this year showed no signs of disturbance. Populations of $A$. funereus are remote and there have been no activities within miles of the populations and it is unlikely there will be any activities in the future. 


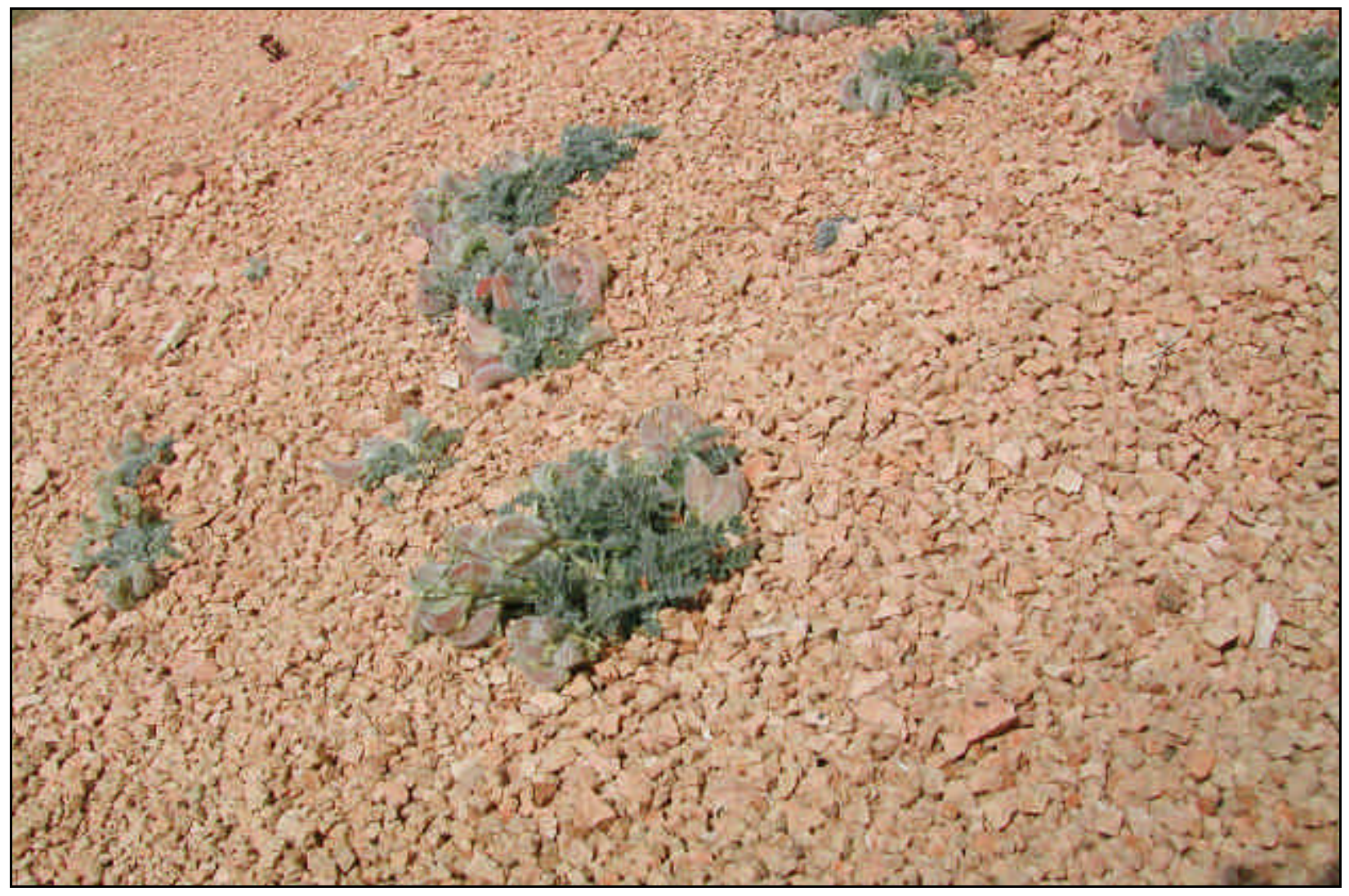

Figure 5-4. A. funereus in fruit along the southern slopes of French Peak in typical habitat: steep slopes (35 percent + ) and light colored volcanic tuff.

(Photo taken by David Anderson in May 2005.)

\subsubsection{Entosthodon planoconvexus}

E. planoconvexus is known from the Mojave, Sonoran and Egyptian deserts (Shabbara, 1999). There is a reported location on the NTS in Rock Valley along north-facing foothills of the Specter Range, at an elevation of 1,149 m (3,770 ft). The Specter Range is made up of limestone hills with steep slopes and narrow ravines. The habitat for this species is unique and described as growing in moist pockets in association with a liverwort, Targionia (Stark et al., 2002; Flowers, 1973).

Prior to the field surveys, specimens of the species were reviewed at the UNLV herbarium and a description of the location where it was collected on the NTS was noted. With this information several survey days were spent along the north-facing slopes of the Specter Range in Rock Valley in Area 25 of the NTS. Several collections of mosses were made during the surveys and one made along the west facing slope of a major drainage off the northern slopes of the Specter Range appears to be E. planoconvexus. The location was approximately $1.6 \mathrm{~km}(1.0 \mathrm{mi})$ from the Rock Valley study site. The collection was made along a rock face with a northwestern exposure in a dense thicket of Symphoricarpus longiflorus (desert snowberry). The moss was growing with a liverwort (Targionia), which is typical of this species (Stark et al., 2002; Flowers, 1973), and in an area infrequently, if ever, receiving direct exposure to the sun light 
(Figure 5-5). A collection was made and the taxonomy of the specimen will be determined by taxonomic experts.

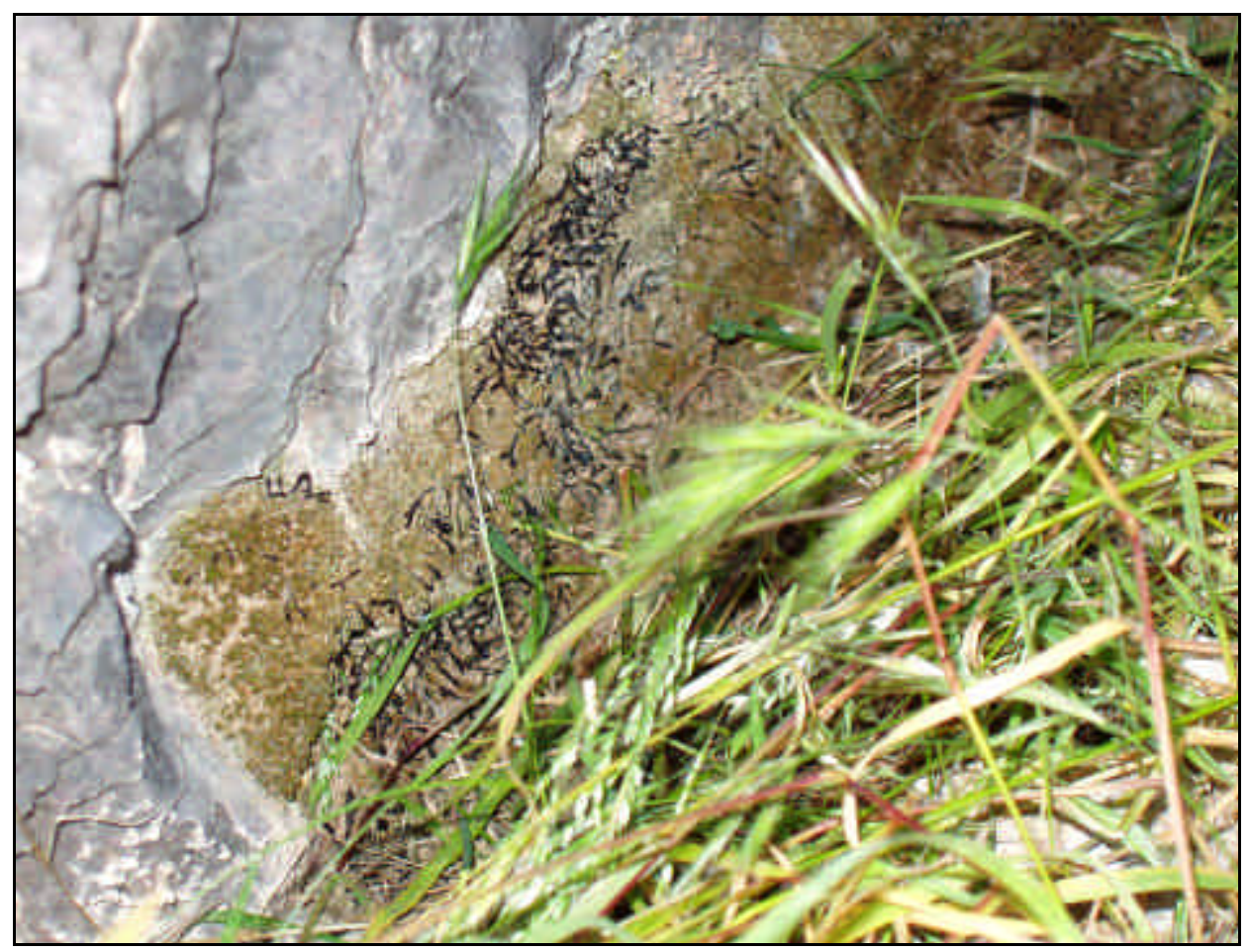

Figure 5-5. E. planoconvexus (pending verification) on northwest-facing rock cove on northern slopes of the Specter Range.

(Photo taken by David Anderson in May 2005.)

\subsubsection{Coordination with Natural Resource Agency Botanists}

The 2005 Nevada Rare Plant Workshop was held in Las Vegas, Nevada on April 5, 2005. The Workshop was co-sponsored by the NNPS and the NNHP. Participants included state and federal agency representatives, academia, land resource managers and private concerns. The workshop provides an opportunity for resource agencies to coordinate their efforts to protect rare plant species and to make recommendations regarding species that may need, or no longer need, protection under state or federal laws and regulations.

The status of Petalonyx thurberi ssp. gilmanii (Death Valley sandpaper plant) was an item for discussion during the 2004 Rare Plant Workshop but status determination was left open pending verification of a reported location at the 'big dunes' in southern Nye County, south of Beatty and south of US 95. This species is known to occur in Death Valley, California and was suspected to occur in Nevada based on two collections annotated as ssp. gilmanii from the big dune area and Ash Meadows. However preliminary examination of the two specimens collected at these two sites which are at the UNLV herbarium, indicate that both collections are ssp. thurberi. Based on this information P. thurberi ssp. gilmanii will be dropped from Nevada Rare Plant List until definitively found in the state (unpublished notes from 2005 Rare Plant Workshop held at Las Vegas, April 5, 2005). 
Echinocereus engelmannii var armatus (armored hedgehog cactus) is known from three sites in California and two on Pahute Mesa within the boundaries of the NTS. It is being considered for addition to the Watch List of the NNHP. This taxon was recognized in 1982 (Benson 1982) but "... in recent floristic studies its taxonomy has been questioned because of its spotty distribution amidst other variants of Echinocereus engelmannii ..." (NNHP Rare Plants Workshop Agenda, 2005). It was recommended that this species be 'dropped' from consideration as a protected species for the state of Nevada due to synonymy.

Several bryophytes were considered for protection during the 2005 Rare Plant Workshop because of their rare occurrence in Nevada and bordering states. Those of interest included Grimmia americanna, Syntrichia bartramii and Pseudocrossidium crinitum, all proposed to be added to the NNHP Watch List. None of these species have been found on the NTS but have been collected at locations in low desert regions of Clark County, Nevada, which suggests that they may be found on the NTS. Another bryophyte, E. planoconvexus (see Section 5.1.2.3), which is known to occur on the NTS, was recommended for listing as threatened on the NNHP Rare Plant List.

\subsection{Sensitive and Protected/Regulated Animal Species}

The NNHP Rare Animal List, Nevada Administrative Code 503, and other sources were reviewed to determine if any changes had been made to the status of species known to occur on the NTS. Noteworthy changes include the addition of dark kangaroo mouse (Microdipodops megacephalus), pale kangaroo mouse (Microdipodops pallidus), pallid bat (Antrozous pallidus), fringed myotis (Myotis thysanodes), and Brazilian free-tailed bat (Tadarida brasiliensis) as Nevada Protected species and Townsend's big-eared bat (Corynorhinus townsendii), western red bat (Lasiurus blossevillii), loggerhead shrike (Lanius ludovicianus), sage thrasher (Oreoscoptes montanus), and brewer's sparrow (Spizella breweri) as Nevada Protected-Sensitive species. There are four designations for Nevada protected animals which include Nevada Protected-Endangered, Nevada Protected-Threatened, Nevada Protected-Sensitive, and Nevada Protected. Species with these designations fall under Protected/Regulated Animal Species unless they are found on the NNHP Sensitive Animal List or bat species with a high or moderate ranking in the Nevada Bat Conservation Plan Bat Species Risk Assessment (Nevada Bat Working Group, 2002). The complete list with current designations is found in the Sensitive and Protected/Regulated Animal Species List (see Table 2-1 shown previously).

Surveys of sensitive and protected/regulated animals during 2005 focused on western burrowing owls (Athene cunicularia hypugaea), bats, kangaroo mice, and feral horses. Opportunistic sightings of other sensitive and protected/regulated animals such as raptors, pronghorn antelope (Antilocapra americana) and mule deer (Odocoileus hemionus) were also recorded.

\subsubsection{Western Burrowing Owl}

Western burrowing owl monitoring entailed monitoring reproduction with remote cameras and trapping owls at their burrows. Additionally, five new burrow sites were found including two burrows in the Mojave Desert Ecoregion, two in the Transition Ecoregion, and one in the Great Basin Desert Ecoregion. This makes a total of 126 known western burrowing owl locations ( 30 owl sightings and 96 burrow sites) on the NTS Figure 5-6).

\subsubsection{Reproduction Monitoring}

Reproduction monitoring using remote cameras was conducted from 1999-2001 to document the number of breeding pairs and the number of young owls per pair (productivity) (Table 5-1). Precipitation received from October to March preceding each breeding season (March to August) during those years 
was average or below average. Precipitation was more than double the average from October 2004 to March 2005, so it was decided to document reproduction in a high precipitation year to see if the number of breeding pairs and the number of young owls per pair increased.

Known burrow sites were checked for fresh sign (i.e., pellets, scat, tracks) in April, May, and July 2005. Burrows with fresh sign were considered active and monitored using motion-activated cameras with active infrared-beam technology (TM1500 active infrared trail monitors, Goodson \& Associates, Inc., Lenexa, Kansas). For more detailed information about this technique see Hall et al., (2003).

Eighteen sites were sampled between May 31 and August 10, and 11 breeding pairs were documented (Figure 5-6 and Table 5-1). A total of 58 young were detected for an average of 5.3 young owls per pair. Four non-breeding pairs were also documented. Figure 5-7 depicts a typical photograph taken by the camera system that is used to identify the number of young owls.

An analysis-of-variance test among years showed no significant difference $(\mathrm{p}=0.156)$ in productivity. This is most likely due to the high degree of variability in the data. Although not statistically significant, it is believed that the low productivity in 1999 is biologically significant, and the data suggest that low precipitation may be the cause for the low productivity. The data also suggest that there is a threshold above which there is no increase in productivity. Thus, one would expect productivity of around 5.0 young owls per pair during years in which precipitation received from October to March preceding the breeding season was normal or above-normal. Clearly, more research is needed to better define this relationship between precipitation and productivity. Furthermore, there are other factors involved in productivity besides precipitation such as prey availability, predation, individual fitness, etc., that were not measured. 


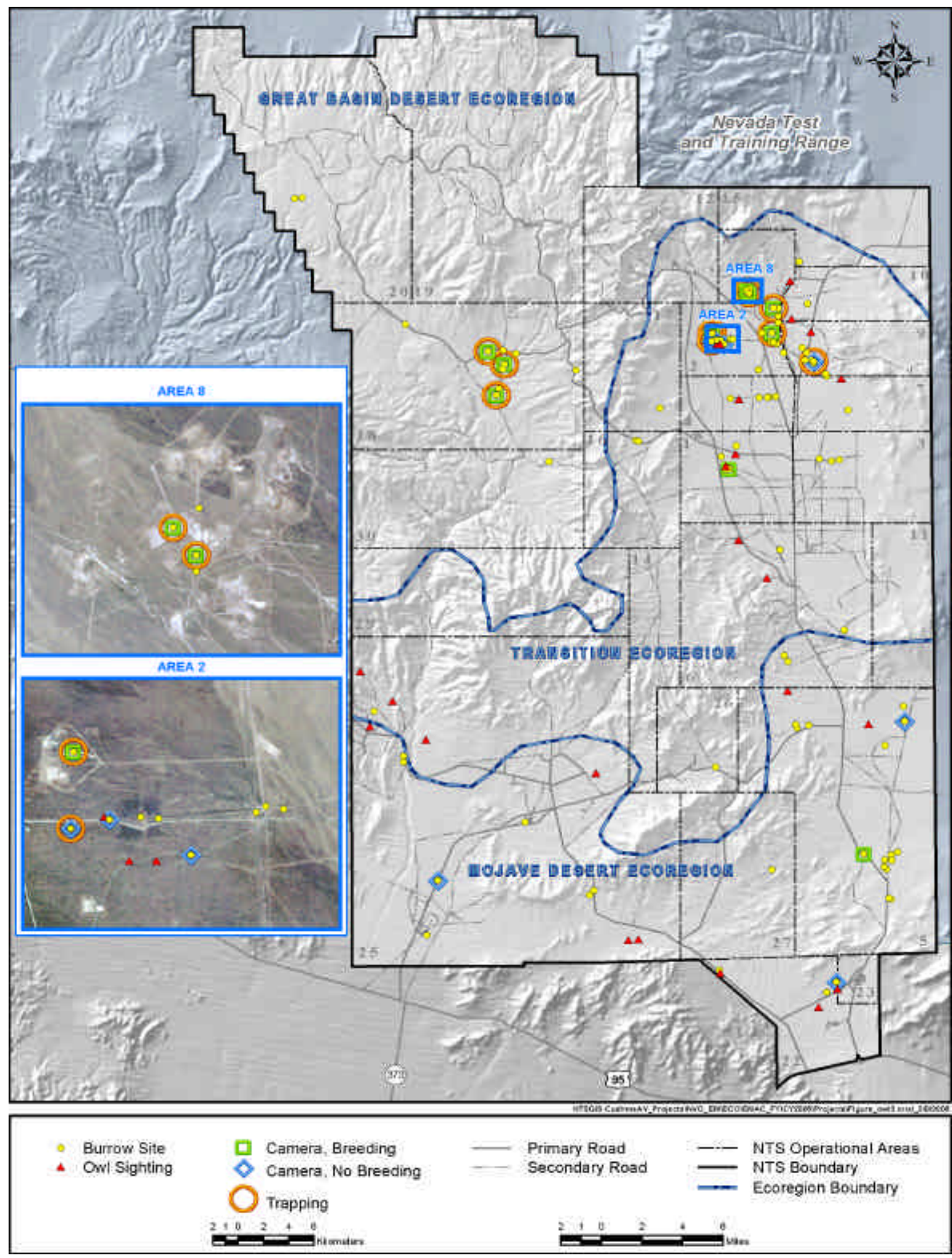

Figure 5-6. Known western burrowing owl distribution on the NTS and burrow sites where motion-activated cameras were set up and/or trapping occurred. 


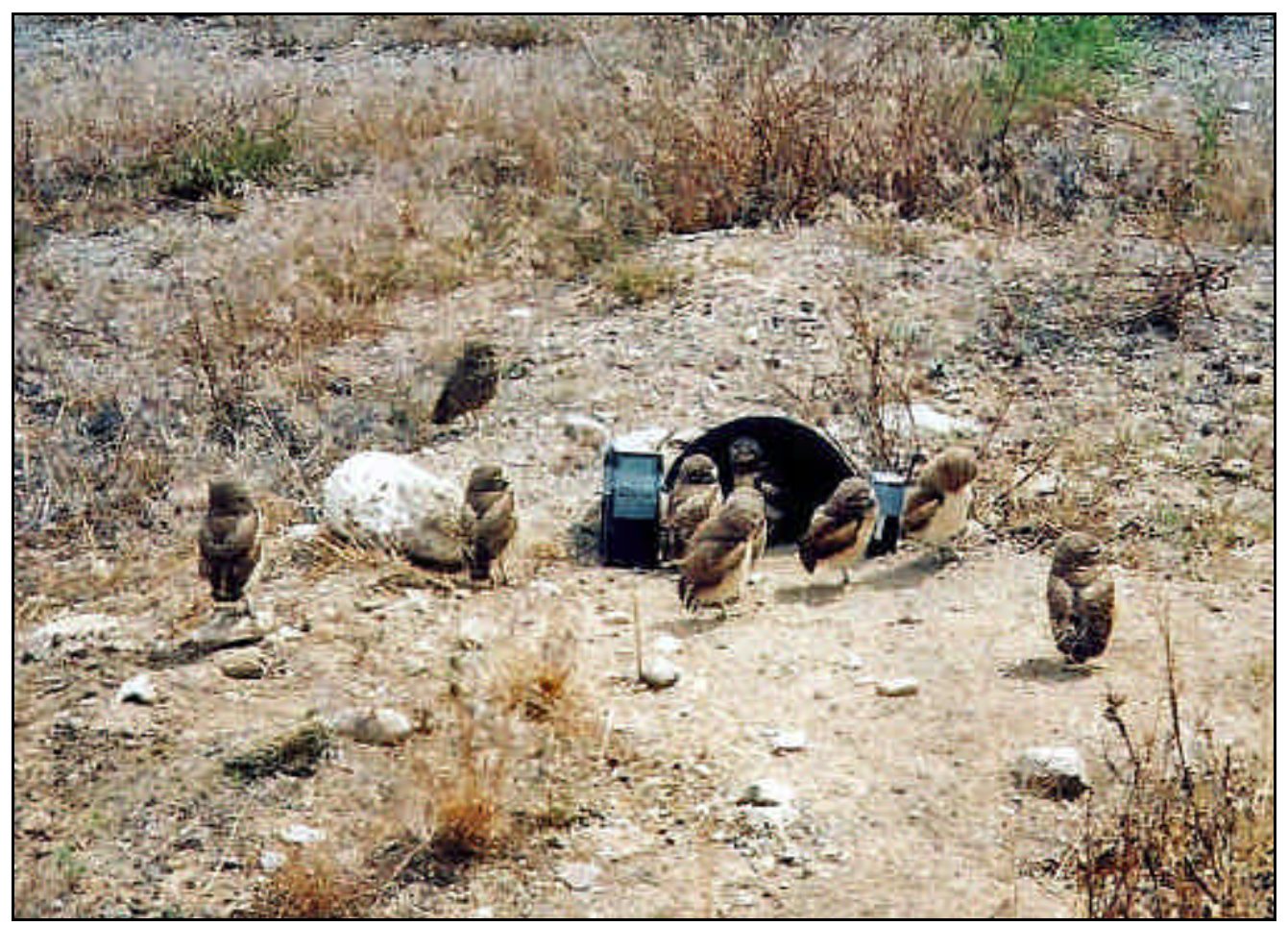

Figure 5-7. Western burrowing owl family on burrow apron including one adult (upper most owl), eight juveniles, and one unknown (behind front center owl) at Burrow \#51, Yucca Flat.

(Photo taken remotely on June 9, 2005.)

Table 5-1. Number of sites sampled, breeding pairs, total young, and average number of young per breeding pair by year for western burrowing owls detected with motionactivated cameras on the NTS (1999-2001; 2005).

\begin{tabular}{|c|c|c|c|c|c|c|c|}
\hline \hline & $\begin{array}{c}\text { Sites } \\
\text { Sampled }\end{array}$ & $\begin{array}{c}\text { Breeding } \\
\text { Pairs }\end{array}$ & $\begin{array}{c}\text { Young } \\
\text { Owls }\end{array}$ & Young/pair & Range & s.d. & Precipitation* $^{*}$ \\
2000 & 24 & 7 & 24 & 3.4 & $1-6$ & 1.6 & 2.29 \\
2001 & 23 & 11 & 55 & 5.0 & $1-8$ & 2.1 & 12.88 \\
2005 & 18 & 11 & 58 & 5.3 & $3-8$ & 1.7 & 22.89 \\
\hline $\begin{array}{c}\text { All } \\
\text { years }\end{array}$ & $45^{\star *}$ & 37 & 180 & 4.9 & $1-8$ & 1.9 & $10.19^{\star * *}$ \\
\hline \hline
\end{tabular}

${ }^{*}$ Precipitation (cm) at BJY (Yucca Flat) for October to March preceding the breeding season

${ }^{* *}$ Number of unique sites; some sites were sampled during multiple years

${ }^{* * *}$ Average precipitation at BJY for October to March 1960-2005 


\subsubsection{Trapping}

Dr. Courtney Conway from the University of Arizona is working on a U.S. Department of Defense (DoD) Legacy funded project evaluating migratory linkages of western burrowing owls in western North America. This involves trapping and banding burrowing owls and taking feather and blood samples. Dr. Conway contacted BN biologists to request their assistance in collecting samples on the NTS. Vicki Garcia, an associate of Dr. Conway, visited the NTS and trained BN biologists to band owls and collect the required samples.

Traps (Figure 5-8) were set out at 10 burrow sites on July 26-28 for a total of 33 trap nights. Twenty-two owls including one adult and 21 juveniles were captured and banded (Figure 5-9 and Table 5-2). Feather and blood samples will be analyzed at a future date by Dr. Conway and his colleagues. Information learned from this cooperative effort will give $\mathrm{BN}$ biologists a greater understanding of western burrowing owl residency and migratory status on the NTS. It may also help determine where owls from the NTS are wintering and potential threats to them at their wintering areas which may help explain any potential future declines of this species on the NTS. Trapping will continue over the next two to three years.

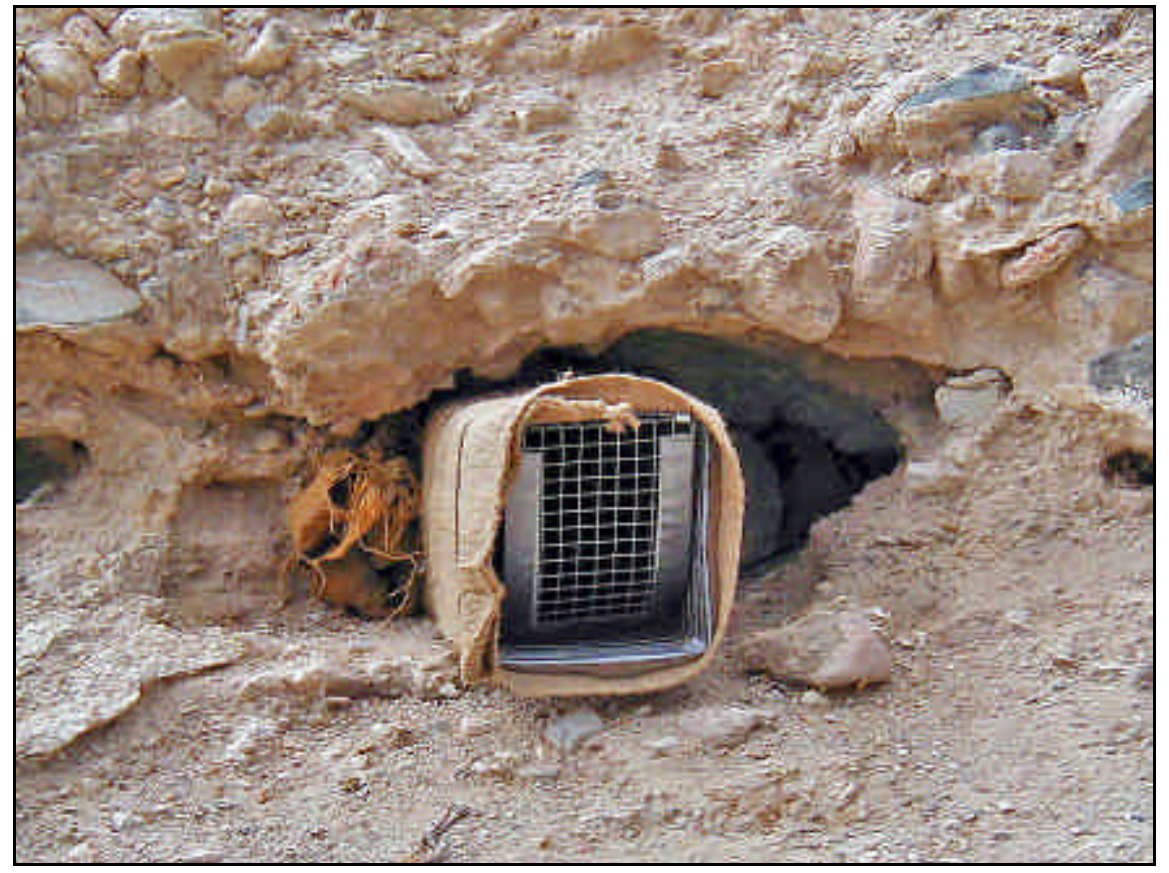

Figure 5-8. Two-way trap set at Burrow \#16, Area 18. (Photo taken by Derek Hall on July 28, 2005.) 


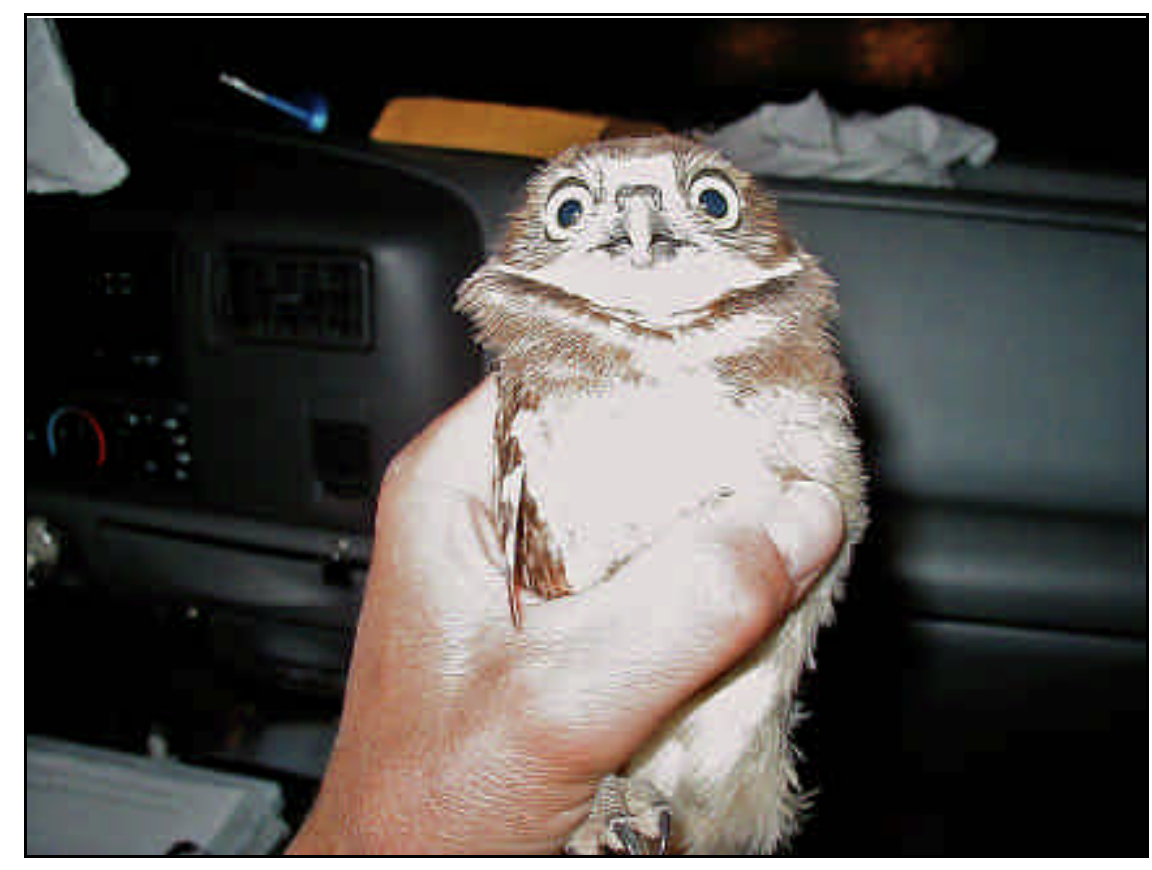

Figure 5-9. Juvenile western burrowing owl.

(Photo taken by Derek Hall on July 28, 2005.)

Table 5-2. Western burrowing owl trapping results on the Nevada Test Site, July 2005.

\begin{tabular}{|c|c|c|c|c|c|c|c|c|c|}
\hline $\begin{array}{c}\text { Site } \\
\text { number/ } \\
\text { Burrow }\end{array}$ & Date & $\begin{array}{l}\text { Trap } \\
\text { Type }\end{array}$ & Sex* & $\begin{array}{r}\text { Weight } \\
\text { (grams) }\end{array}$ & $\begin{array}{c}\text { Juvenile } \\
\text { Age (days) }\end{array}$ & $\begin{array}{l}\text { Acraft } \\
\text { band \# }\end{array}$ & $\begin{array}{l}\text { USFWS } \\
\text { band \# }\end{array}$ & $\begin{array}{l}\text { Feathers } \\
\text { collected }\end{array}$ & $\begin{array}{l}\text { Blood } \\
\text { collected }\end{array}$ \\
\hline $76 / A$ & $7 / 26$ & 2-way & $\mathrm{J}$ & 148 & 41 & $\operatorname{Re}-7 Y$ & $844-69923$ & Yes & Yes \\
\hline 67/A & $7 / 26$ & 2-way & $\mathrm{J}$ & 123 & 45 & $\operatorname{Re}-4 \mathrm{Y}$ & $844-69920$ & Yes & Yes \\
\hline $67 / \mathrm{A}$ & $7 / 26$ & 2-way & $J$ & 129 & 42 & Re-5Y & $844-69921$ & Yes & Yes \\
\hline 67/A & $7 / 26$ & 2-way & $\mathrm{J}$ & 126 & 42 & Re-6Y & $844-69922$ & Yes & No \\
\hline 67/B & $7 / 26$ & 2-way & $J$ & 138 & 47 & Re-2Y & $844-69918$ & Yes & Yes \\
\hline 67/B & $7 / 26$ & 2-way & $\mathrm{J}$ & 123 & 45 & Re-3Y & $844-69919$ & Yes & Yes \\
\hline $51 / \mathrm{A}$ & $7 / 26$ & 2-way & $F$ & 148 & Adult & $\operatorname{Re}-1 Y$ & $844-69917$ & Yes & Yes \\
\hline $64 / A$ & $7 / 26$ & 2-way & $\mathrm{J}$ & 132 & 48 & Re-6R & $844-69924$ & Yes & Yes \\
\hline $64 / A$ & $7 / 26$ & Spring & $\mathrm{J}$ & 154 & 55 & $\operatorname{Re}-7 X$ & $844-69916$ & Yes & No \\
\hline $79 / A$ & $7 / 27$ & 2-way & $\mathrm{J}$ & 121 & 49 & Re-7R & $844-69925$ & Yes & Yes \\
\hline $79 / A$ & $7 / 27$ & 2-way & $\mathrm{J}$ & 146 & 55 & Re-9R & $844-69926$ & Yes & Yes \\
\hline $79 / A$ & $7 / 27$ & 2-way & $\mathrm{J}$ & 111 & 44 & Re-7S & $844-69931$ & Yes & No \\
\hline $79 / A$ & $7 / 27$ & 2-way & $\mathrm{J}$ & 115 & 53 & Re-2U & $844-69928$ & Yes & Yes \\
\hline $79 / A$ & $7 / 27$ & 2-way & $\mathrm{J}$ & 112 & 51 & $\operatorname{Re}-1 \mathrm{U}$ & $844-69929$ & Yes & No \\
\hline $79 / A$ & $7 / 27$ & 2-way & $J$ & 128 & 48 & Re-4U & $844-69930$ & Yes & No \\
\hline 79/B & $7 / 27$ & 2-way & $\mathrm{J}$ & 131 & 55 & Re-8R & $844-69932$ & Yes & Yes \\
\hline 79/B & $7 / 27$ & 2-way & $\mathrm{J}$ & 108 & 47 & Re-2S & $844-69927$ & Yes & Yes \\
\hline $16 / A$ & $7 / 28$ & 2-way & $J$ & 133 & 40 & $\operatorname{Re}-9 \mathrm{U}$ & $844-69937$ & Yes & Yes \\
\hline $16 / A$ & $7 / 28$ & 2-way & $J$ & 138 & 40 & Re-8U & $844-69936$ & Yes & Yes \\
\hline $37 / \mathrm{A}$ & $7 / 28$ & 2-way & $J$ & 130 & 40 & Re-6U & $844-69934$ & Yes & Yes \\
\hline $37 / \mathrm{A}$ & $7 / 28$ & 2-way & $J$ & 118 & 39 & Re-5U & $844-69933$ & Yes & No \\
\hline $37 / \mathrm{A}$ & $7 / 28$ & 2-way & $J$ & 125 & 39 & Re-7U & $844-69935$ & Yes & Yes \\
\hline
\end{tabular}

${ }^{*} \mathrm{~J}=$ Juvenile, F=Female 


\subsubsection{Sensitive and/or Protected/Regulated Bat Species (SPRBS)}

In 2005, 12 sites were monitored for bat presence (Figure 5-10). Of these sites, seven were water sources and five were tunnels or abandoned mines. Only one bat was captured, a long-legged myotis (Myotis volans) which is a non-SPRBS. One reason for the low captures is many sites were not conducive to netting over the water source or over the mine opening. However, acoustic monitoring at these sites yielded 1,670 electronic files representing 12 species including 10 SPRBS (Table 5-3). An additional SPRBS, the spotted bat (Euderma maculatum), was detected by its audible call. Of the 15 known bat species to occur on the NTS, all but the silver-haired bat (Lasionycteris noctivagans) and the Townsend's big-eared bat were detected. No new species were detected.

A variety of techniques were used to monitor bat activity. These included direct capture with mist nets, recording ultrasonic echolocation calls using the Anabat $\mathrm{II}^{\mathrm{TM}}$ system (Titley Electronics, Ballina, Australia), recording bat activity with a special night vision camera equipped with NightSight ${ }^{\mathrm{TM}}$ technology attached to a camcorder, and observing bat activity with night vision goggles. The mobile Anabat II ${ }^{\mathrm{TM}}$ system was used again this year and made it possible to monitor two sites at the same time which made sampling much more cost-effective. Generally, the mobile system was set up at one site and a biologist would watch the tunnel, shaft, or adit opening with night vision goggles and another biologist would monitor another site with the NightSight ${ }^{\mathrm{TM}}$ camera and an Anabat II $^{\mathrm{TM}}$ system hooked up to a laptop computer. Calls recorded with the Anabat II $^{\mathrm{TM}}$ systems were submitted to O'Farrell Biological Consulting for analysis and species identification. Data collected from bat monitoring expand the known distribution and identify critical habitat for bats on the NTS. 


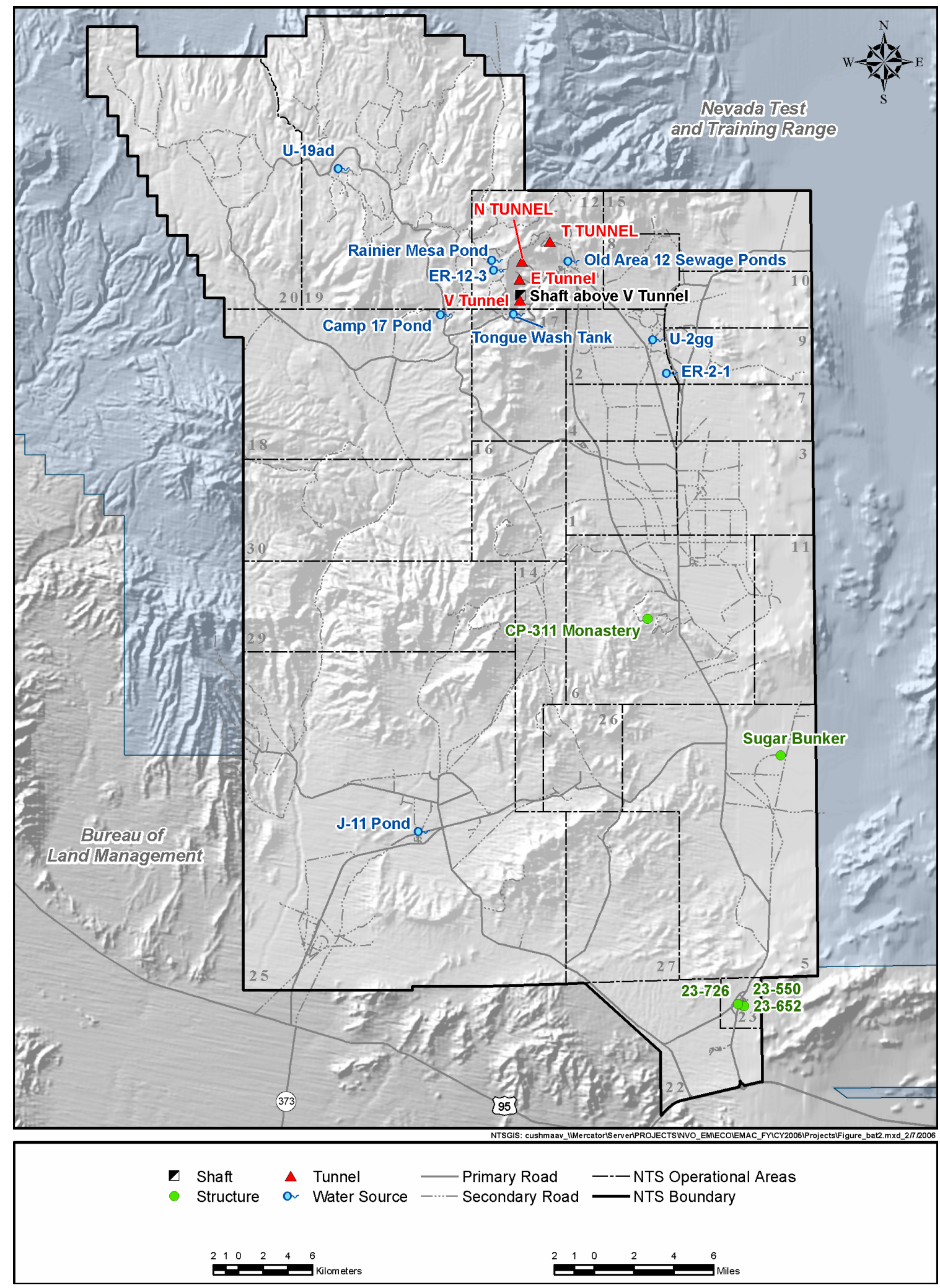

Figure 5-10. Sites monitored for bat activity during 2005 including buildings where day roosts were documented and sites sampled for biota dose assessment. 
Table 5-3. Number of electronic files of bat calls at sites monitored in 2005.

\begin{tabular}{|c|c|c|c|c|c|c|c|c|c|c|c|c|c|}
\hline $\begin{array}{c}\text { Location } \\
\text { (Monitoring Dates) }\end{array}$ & 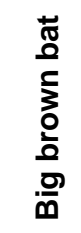 & 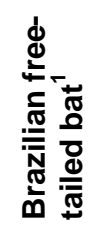 & 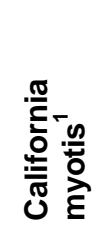 & 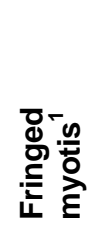 & 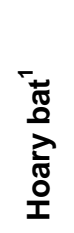 & 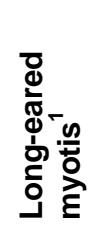 & 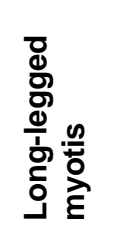 & $\begin{array}{l}\overline{7} \\
\frac{7}{0} \\
\overline{\overline{0}} \\
0\end{array}$ & 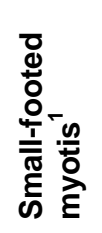 & 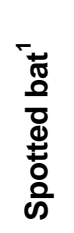 & 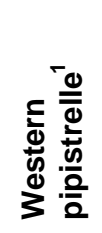 & 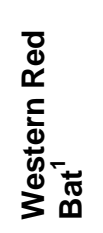 & \\
\hline \multicolumn{14}{|l|}{ Water Sources } \\
\hline U2gg Plastic-lined Sump (6/6) & 2 & 1 & 4 & & & & 41 & 2 & 28 & & 3 & & \\
\hline Rainier Mesa Pond (6/7) & & & & & & & $1 M, 25$ & & 9 & & & & \\
\hline ER 2-1 Plastic-lined Sump (6/13) & & & 6 & & & & 27 & 1 & 101 & & 131 & & \\
\hline Tongue Wash Tank (6/14) & & & 13 & 26 & & & 61 & & 124 & & & 1 & 3 \\
\hline Old Area 12 Sewage Pond (8/9) & 6 & & 3 & & & & 15 & 2 & 25 & & 14 & & \\
\hline ER 12-3 Earthen Sump (9/6) & & & 1 & 6 & & 5 & 117 & 5 & 158 & & & & \\
\hline ER U19ad Plastic-lined Sump (9/7) & 63 & 1 & 4 & 42 & 6 & 18 & 271 & & 229 & $A$ & 14 & & \\
\hline \multicolumn{14}{|l|}{ Tunnels and Mines } \\
\hline V Tunnel (3 portals) (6/20) & & & 6 & 1 & & & & & 19 & & 3 & & 2 \\
\hline Shaft above V Tunnel (8/8) & & & & & & & 2 & & 5 & & 1 & & \\
\hline E Tunnel (2 portals) (9/12) & & & 13 & 8 & & 4 & 11 & & 3 & & 8 & & \\
\hline N Tunnel (2 portals) (9/26) & & & 45 & 1 & & 6 & 23 & & 24 & & 5 & & \\
\hline T Tunnel $(9 / 27)$ & & & 24 & & & 2 & 6 & & 18 & & & & \\
\hline No. Sites & 3 & 2 & 10 & 6 & 1 & 5 & 11 & 4 & 13 & 1 & 9 & 1 & 2 \\
\hline Total No. of Electronic Files & 71 & 2 & 119 & 84 & 6 & 35 & 599 & 10 & 743 & $A$ & 179 & 1 & 5 \\
\hline
\end{tabular}

\footnotetext{
${ }^{1}$ Sensitive and/or Protected/Regulated species (see Table 2-1); $\mathrm{A}=$ audible call, presumably spotted bat call; $1 \mathrm{M}=$ one male bat caught.
} 


\subsubsection{Bat Occurrence at Water Sources}

Of the seven water sources monitored, six were human-made and one was natural. The one bat captured was a juvenile, male, long-legged myotis suggesting this species is breeding on the NTS. Audible calls, presumably made by spotted bats, were heard several times at U19ad. Results from the analysis of 1,408 files reveal the presence of 10 SPRBS and two non-SPRBS (Table 5-3). With the audible spotted bat calls, 13 bat species were detected, including 11 SPRBS and two non-SPRBS. The small-footed myotis (M. ciliolabrum) and long-legged myotis were the two most frequently detected species acoustically. Bats were detected at all sites.

\subsubsection{Bat Occurrence at Potential Roost Sites}

Of the five potential roost sites monitored, four were tunnels and one was a shaft. Results from the analysis of 262 files reveal the presence of seven species including six SPRBS and one nonSPRBS (Table 5-3). California myotis and small-footed myotis were the most frequently detected species. Bats were detected at all sites.

\subsubsection{Identification of Roost Sites}

Bats are known to have day roosts where they remain from dawn until dusk and night roosts where they rest between foraging forays. Maternity roosts are sites where females give birth and rear their young. Some maternity roosts are communal, containing large colonies of one or more species of bats. Data from mist net captures, review of recorded video tapes, visual observations, and acoustic data were all examined to determine bat use designations for the potential roost sites monitored. These designations included: $\mathrm{M}=$ maternity roost where lactating females or juveniles were captured in mist nets and bats were also seen exiting the site near dusk, $D=$ day roost where bats were observed flying out of the site near dusk, N/FS=night roost and/or foraging site where bats were observed flying in and out of or foraging within the site, and I=indeterminate use where bats were only observed flying over or around the site and not flying in or out of it. Of the five potential roost sites sampled, two are day roosts ( $\mathrm{E}$ and $\mathrm{N}$ Tunnels) and three are night roosts/foraging sites ( $\mathrm{T}$ and $\mathrm{V}$ Tunnels, shaft above $\mathrm{V}$ Tunnel).

\subsubsection{Biota Dose Assessment Monitoring}

A DOE document, "A Graded Approach for Evaluating Radiation Doses to Aquatic and Terrestrial Biota" (DOE, 2002a) outlines methods to assess radiation doses to biota. E Tunnel Ponds (Area 12, Figure 5-10) are contaminated, perennial water sources at which bats are known to drink and forage. Because bats are relatively long-lived (10 to 20 years) and most species on the NTS do not migrate, there is a potential for these animals to uptake radionuclides through regular drinking and foraging at contaminated sites. Therefore, in conjunction with routine bat monitoring, 29 bats (seven species) were collected at E Tunnel Pond 5 and eight bats (one species) were collected in 2004 at a control site, J-11 Pond (Area 25, Figure 5-10 and Table 5-4) and results reported this year (2005). Invertebrates were also collected because this is the primary food source for bats that occur on the NTS. A total of $10.3 \mathrm{~g}$ (wet weight) of flying insects, representing seven Orders (Odonata, Lepidoptera, Neuroptera, Diptera, Hymenoptera, Coleoptera, Hemiptera) was collected approximately $10 \mathrm{~m}$ from E Tunnel Pond 5.

Samples were composited to obtain adequate sample size in all cases except for the one big brown bat (Eptesicus fuscus) which was large enough to be an individual sample (Table 5-4). Water was distilled from each sample and submitted to a laboratory for tritium $(3 \mathrm{H})$ analysis. The dried tissue samples were also submitted to a laboratory but for analysis of gamma-emitting 
radionuclides, ${ }^{90}$ Strontium, ${ }^{239+240}$ Plutonium, and ${ }^{241}$ Americium. Results were not available for last year's report, so they are being included in this year's report.

Tritium, ${ }^{137}$ Cesium, ${ }^{239+240} \mathrm{PU}$, and ${ }^{241} \mathrm{Am}$ were detected in the samples from E Tunnel Pond 5 (Table 5-5). Dose rates were calculated and compared with DOE recommended levels. Dose rates to bats from internal man-made radionuclides ranged from $7.0 \times 10^{-9} \mathrm{Rad} /$ day to $2.0 \times 10^{-5}$ $\mathrm{Rad} /$ day (mean $8.0 \times 10^{-6} \mathrm{Rad} /$ day; median $7.0 \times 10^{-6} \mathrm{Rad} /$ day) and were predominantly from tritium. These levels are less than one percent of the DOE recommended dose limit of 0.1

$\mathrm{Rad} /$ day for the protection of terrestrial biota. These data suggest that bats drinking and foraging over E Tunnel Pond 5 are not receiving internal doses from man-made radionuclides that would be considered harmful.

Table 5-4. Animals sampled in 2004 at E Tunnel Pond 5 and J-11 Pond (control site) and results reported this year. Samples in the same row were composited.

\begin{tabular}{|c|c|c|}
\hline \multirow[b]{2}{*}{ Location } & \multicolumn{2}{|c|}{ Samples } \\
\hline & $\begin{array}{c}\text { [Number of Individuals] } \\
\text { Common Name (Scientific Name) }\end{array}$ & $\begin{array}{c}\text { [Number of Individuals] } \\
\text { Common Name (Scientific Name) }\end{array}$ \\
\hline E Tunnel Pond 5 & $\begin{array}{l}\text { [1] big brown bat (Eptesicus fuscus) } \\
\text { [3] fringed myotis (Myotis thysanodes) } \\
\text { [5] long-legged myotis (Myotis volans) } \\
\text { [5] small-footed myotis (Myotis ciliolabrum) } \\
\text { [5] small-footed myotis (Myotis ciliolabrum) } \\
\text { [7] western pipistrelle (Pipistrellus hesperus) } \\
\text { [10.3 grams wet weight] Invertebrates (from t } \\
\text { Neuroptera, Diptera, Hymenoptera, Coleopte }\end{array}$ & $\begin{array}{l}+\quad \text { [2] long-eared myotis (Myotis evotis) } \\
+\quad \text { [1] California myotis (Myotis } \\
\text { californicus) } \\
\text { lowing Orders: Odonata, Lepidoptera, } \\
\text { emiptera) }\end{array}$ \\
\hline J-11 Pond & [8] western pipistrelle (Pipistrellus hesperus) & \\
\hline
\end{tabular}


Table 5-5. Radionuclide concentrations in animals sampled in 2004 from E Tunnel Pond 5 and J-11 Pond (control site) and results reported this year. Shaded values (green) are considered detections above minimum detectable concentrations.

\begin{tabular}{|c|c|c|c|c|c|c|c|c|c|c|c|c|}
\hline \multirow[b]{2}{*}{ Samples } & \multicolumn{12}{|c|}{ Radioncuclide Concentratons \pm Uncertainty* } \\
\hline & \multicolumn{3}{|c|}{$3 \mathrm{H}(\mathrm{pCi} / \mathrm{L})^{* *}$} & \multicolumn{3}{|c|}{$137 \mathrm{Cs}(\mathrm{pCi} / \mathrm{g}) * * *$} & \multicolumn{3}{|c|}{ 239/240Pu (pCi/g) } & \multicolumn{3}{|c|}{ 241Am (pCi/g) } \\
\hline \multicolumn{13}{|l|}{ E Tunnel Pond 5} \\
\hline Invertebrates & 42014 & \pm & 2030 & 0.310 & \pm & 0.236 & 0.000 & \pm & 0.003 & 0.008 & \pm & 0.006 \\
\hline \multicolumn{13}{|l|}{ Species (No. of Bats) } \\
\hline $\begin{array}{l}\text { Big Brown Bat (1) } \\
\text { Fringed \& Long-eared }\end{array}$ & 66471 & \pm & 1857 & 0.103 & \pm & 0.107 & 0.004 & \pm & 0.003 & 0.000 & \pm & 0.001 \\
\hline Myotis (5) & 60312 & \pm & 2002 & 0.206 & \pm & 0.195 & 0.000 & \pm & 0.016 & 0.003 & \pm & 0.004 \\
\hline Long-legged Myotis (5) & 50631 & \pm & 1609 & 0.638 & \pm & 0.164 & 0.007 & \pm & 0.016 & 0.008 & \pm & 0.006 \\
\hline Small-footed \& California & & & & & & & & & & & & \\
\hline Myotis (6) & 19110 & \pm & 1328 & 0.081 & \pm & 0.090 & -0.010 & \pm & 0.015 & 0.001 & \pm & 0.004 \\
\hline Small-footed Myotis (5) & 15081 & \pm & 1194 & 0.088 & \pm & 0.094 & 0.013 & \pm & 0.018 & 0.002 & \pm & 0.003 \\
\hline Western Pipistrelle (7) & 43111 & \pm & 1956 & 0.016 & \pm & 0.324 & -0.006 & \pm & 0.021 & 0.004 & \pm & 0.005 \\
\hline \multicolumn{13}{|l|}{ J-11 - Control } \\
\hline Western Pipistrelle (8) & 62 & \pm & 897 & 0.030 & \pm & 0.056 & 0.002 & \pm & 0.003 & 0.000 & \pm & 0.001 \\
\hline $\begin{array}{c}\text { Average Minimum } \\
\text { DetectableConcentration: }\end{array}$ & \multicolumn{3}{|c|}{1189} & \multicolumn{3}{|c|}{0.139} & \multicolumn{3}{|c|}{0.027} & \multicolumn{3}{|c|}{0.007} \\
\hline
\end{tabular}

$* \pm 2$ standard deviations

** Concentration of $3 \mathrm{H}$ in water distilled from the sample

*** Concentrations are per gram dry weight of sample 


\subsubsection{Reported Day Roosts In Buildings}

Fourteen bats in or around buildings were found day roosting on 12 occasions at five buildings (3 in Mercury, 1 in Area 5, and 1 in Area 6) (Figure 5-10 shown previously). Nine of the 12 bats were found at one building, 23-652, in Mercury. Eleven bats were either California or small-footed myotis, two were California myotis, and one was a Townsend's big-eared bat. Results from biological surveys of buildings and reports by others of bats in buildings enable BN biologists to increase their knowledge about bat roosting sites on the NTS. Roost site locations will continue to be documented and stored in the EGIS faunal database.

\subsubsection{Passive Acoustic Monitoring System}

In order to learn more about long-term bat activity over different seasons and years, a passive acoustic monitoring system was installed at Camp 17 Pond (Figure 5-11) on September 22, 2003.

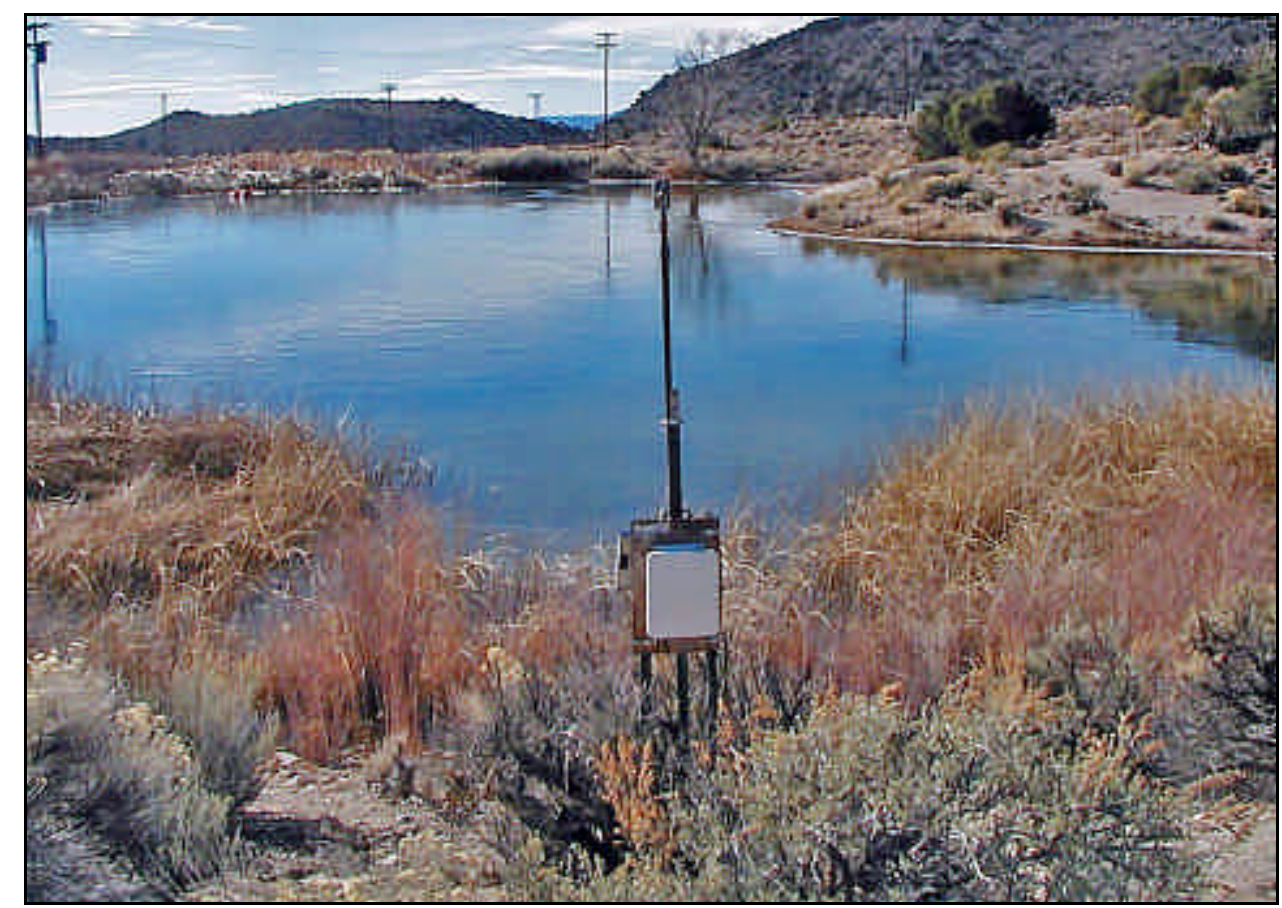

Figure 5-11. Passive acoustic monitoring system at Camp 17 Pond. (Photo taken by Derek Hall on November 30, 2004.)

Tens of thousands of electronic files containing bat calls have been recorded and are in the process of being analyzed by O'Farrell Biological Consulting. Species identification for files collected during the winters of 2003-04 and 2004-05 are complete. In order to more easily summarize these data, the BAT Loader utility was developed by Robert Peppard, a BN Senior Scientist. This utility was developed using Microsoft VisualStudio.net to automate the collation and interpretation of data collected with anabat equipment. BAT Loader's foremost feature is to import anabat files directly into an Access or SQL data base, thus eliminating the time-consuming, error-prone process of pasting information in spreadsheets. Also, Excel has a maximum number of records that can be stored which is 64,000; whereas, SQL databases don't have this limitation. Further, by utilizing an Access or SQL data base standard; preprocessing, summations, and organization of anabat files is done automatically, and the data can be 
reduced into pivot tables to generate finished tables of number of calls, number of files, minutes of activity, similarity indices, etc.

If one or more calls of a species were present during a minute, it was counted as a minute of activity. Minutes of activity by species by month for December through February 2003-04 and 2004-05 (Table 5-6) reveal some new information about winter bat activity. A total of 6,395 minutes of activity of ten species was recorded. Of particular interest is the fact that silver-haired bats, small-footed myotis, and long-legged myotis were previously not documented to be winter active in this region, based on a large amount of capture data (Mike O'Farrell, personal communication). Not only were these species active in the winter, but they were some of the most active species, accounting for 70 percent of total winter activity. The data also suggest that activity is highest in December and steadily declines to its lowest in February. Activity was also higher in 2003-04 than in 2004-05.

Table 5-6. Minutes of winter bat activity by species and month.

\begin{tabular}{|c|c|c|c|c|c|c|c|}
\hline & 2003 & 2004 & 2004 & 2004 & 2005 & 2005 & \\
\hline Species & Dec & Jan & Feb & Dec & Jan & Feb & Total \\
\hline Brazilian free-tailed bat & 2 & & & 16 & 4 & & 22 \\
\hline California myotis & 422 & 170 & 31 & 221 & 3 & & 847 \\
\hline Fringed myotis & 6 & 2 & & 8 & 2 & & 18 \\
\hline Long-eared myotis & & 3 & & & & & 3 \\
\hline Long-legged myotis & 569 & 248 & 37 & 308 & 16 & 10 & 1188 \\
\hline Pallid bat & 212 & 99 & 45 & 111 & 17 & 2 & 486 \\
\hline Silver-haired bat & 345 & 146 & 77 & 140 & 55 & 8 & 771 \\
\hline Small-footed myotis & 947 & 515 & 83 & 936 & 32 & 14 & 2527 \\
\hline Townsend's big-eared bat & & 7 & & & & & 7 \\
\hline Western pipistrelle & 168 & 173 & 52 & 119 & 14 & & 526 \\
\hline Grand Total & 2671 & 1363 & 325 & 1859 & 143 & 34 & 6395 \\
\hline
\end{tabular}

Another way to look at the data is minutes of activity in 0.5 -hour increments from sunset. Previous capture data for this region showed no winter activity greater than four hours after sunset (Mike O'Farrell, personal communication). Our data show that 37.6 percent of all winter activity $(2,402$ of 6,395 minutes) occurred greater than four hours after sunset (Figure 5-12).

Climatic data such as temperature, humidity, wind speed, and barometric pressure are also being recorded at or near Camp 17 Pond. A cursory look at temperature data plotted against bat activity suggests that activity tracks temperature to a large extent (Figure 5-13). However, other factors may also influence activity such as precipitation and ice on the pond (100 percent iced-over on December 22, 2003-January 12, 2004). This figure also shows the range of temperatures at which bats are active with activity occurring even when average nightly temperatures are below zero. More work remains to be done to correlate bat activity with climatic data to help biologists understand the relationship between bat activity 
and weather. A utility similar to BAT Loader will be developed to manipulate the climatic data into a form that is readily comparable to bat activity at the same temporal scale.

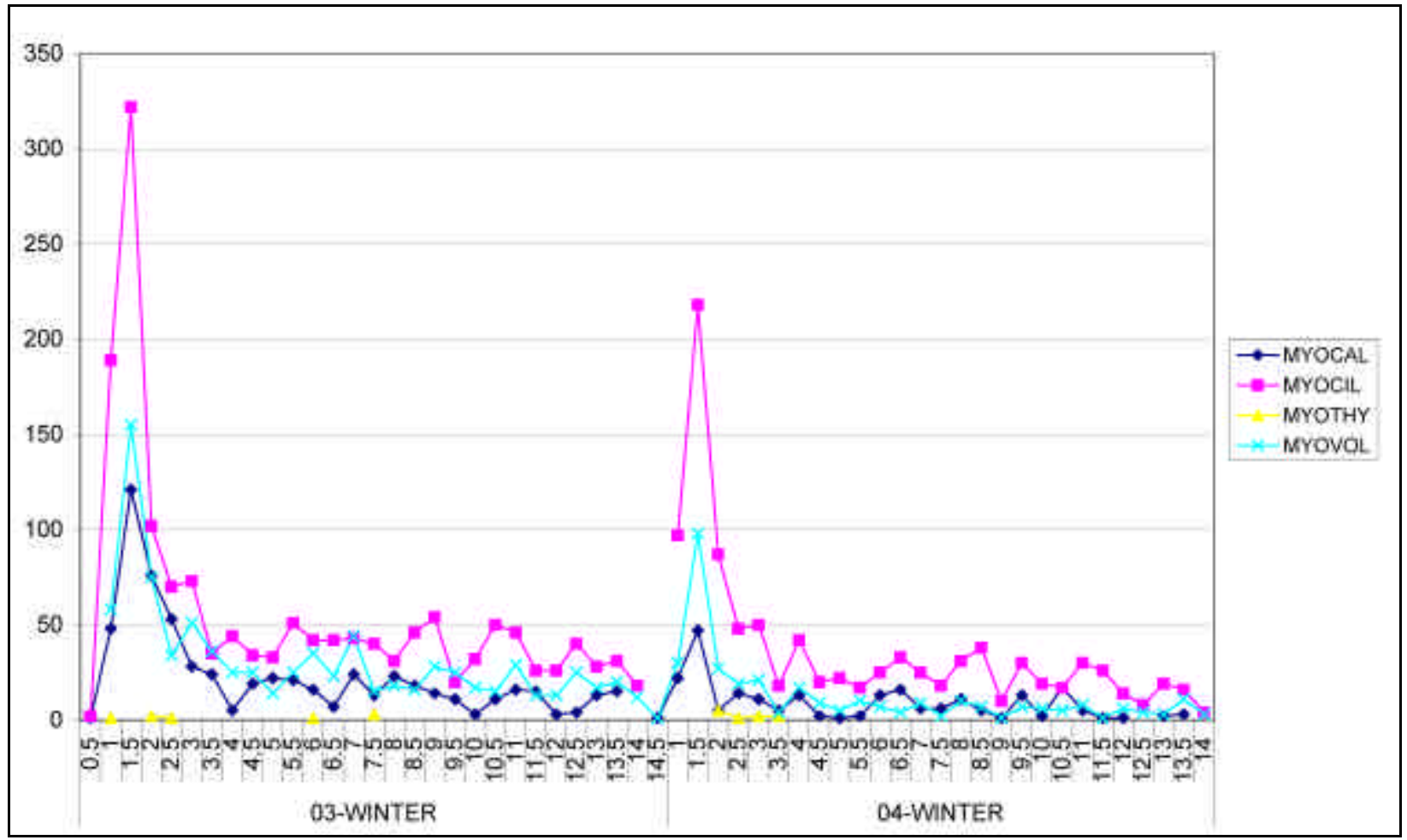

Figure 5-12. Minutes of winter bat activity in 0.5-hour increments from sunset for California myotis (MYOCAL), small-footed myotis (MYOCIL), fringed myotis (MYOTHY), and long-legged myotis (MYOVOL). 


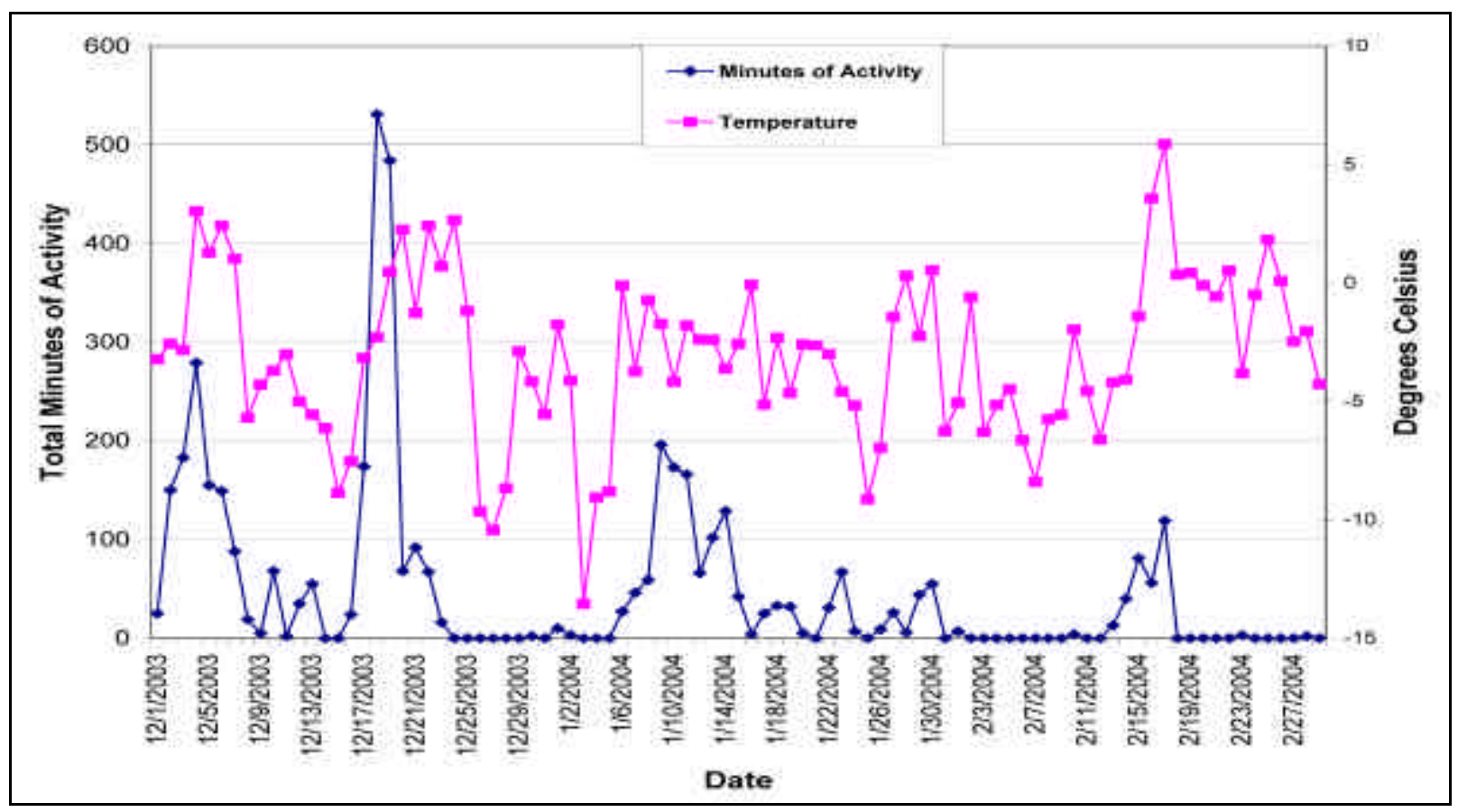

Figure 5-13. Minutes of winter bat activity (December 2003 through February 2004) and average nightly ambient air temperature (6 pm to 6 am Pacific Standard Time).

The passive acoustic monitoring system at Camp 17 Pond is useful for documenting bat activity (e.g., number of calls, number of files, minutes of activity) at various temporal scales (e.g., half-hour increments from sunset, nightly, monthly, seasonally, annual) for as long as one wants to monitor. Species inventories can be developed from data collected by this system, including species that are difficult to capture. Trends in bat activity over time can be analyzed, and patterns of activity can be correlated with weather parameters. Additionally, comparisons can be made with data from other sites across regions to look at things such as migration patterns and species distribution. Similar systems have been set up in the last year or two throughout Nevada. Data collected from our system raise many questions that remain to be answered. For instance, why are bats at Camp 17 Pond so active during the winter? Are they foraging on insects or do they need to drink to maintain their water balance? Why are they active throughout the night even during the coldest part, well after sunset? While these systems don't answer all the questions, they do provide data to start asking questions never asked before.

\subsection{West Nile Virus Surveillance}

West Nile Virus (WNV) is a potentially serious illness that is spread to humans and other animals through mosquito bites. It was first discovered in Uganda in 1937 and was not detected in North America until 1999. In southern Nevada, it was not detected until the spring of 2004. WNV surveillance continued during 2005 to determine if mosquitoes on the NTS carry WNV. WNV surveillance entails setting mosquito traps baited with dry ice overnight at sites where standing water provides a potential breeding ground for mosquitoes (Figure 5-14). As the dry ice sublimates, it produces carbon dioxide which serves as an attractant for mosquitoes. Ten sites were sampled during 16 surveys (Table 5-7). Mosquitoes were taken to Clark County Health District personnel for species identification and WNV testing. A total of 
77 individuals representing three species were captured and analyzed. All specimens tested for WNV were negative except for one Culiseta inornata from Well 3 Pond which was suspect. Suspect means inconclusive, neither positive nor negative. Clark County Health District personnel treat suspect the same as negative. Therefore, WNV has yet to be documented on the NTS. Mosquito species identified will be entered into the EGIS faunal database to define mosquito distribution on the NTS. Sampling will continue next spring and summer to determine if mosquitoes on the NTS have WNV.

Additionally, three injured raptors (red-tailed hawk [Buteo jamaicensis], golden eagle [Aquila chrysaetos], and barn owl [Tyto alba]) taken to the North Las Vegas Animal Hospital for treatment all tested negative for WNV.

\subsection{Mountain Lion Camera Surveys}

Very little data exists for mountain lion (Puma concolor) numbers and distribution in southern Nevada. Erin Boydston, a research scientist with USGS, received funding to investigate mountain lion distribution and numbers using remote, motion-activated cameras. BN biologists are working with Erin in a collaborative effort to set up several cameras on the NTS to help determine how many mountain lions are found here and where they occur. Limited surveys were conducted this year to field test a few different camera systems and ensure they worked properly.

To date, 57 records from opportunistic sightings of mountain lions or their sign have been recorded on the NTS. In 2005, two sub-adult mountain lions were seen in Yucca Flat (one dead at Icecap pad

[Area 7]; one alive in Wet and Wild compound [Area 6]). This is not typical habitat for them and may be an indication that mountain lion populations are thriving in the mountainous areas of the western and northern portions of the NTS with available territories filled by adult males, thus requiring the sub-adult males to travel across Yucca Flat in search of finding their own territories in the mountains to the east. Sub-adult males looking for new territories could pose a potential threat to NTS workers. Knowing how many mountain lions occur and how they are distributed on the NTS will enable BN biologists to better assess the potential threat of mountain lions to NTS workers.

During 2005, remote, motion-activated cameras (TM1500 active infrared and TM550 passive infrared trail monitors, Goodson \& Associates, Inc., Lenexa, Kansas) were set up at seven sites (Table 5-8). Sites were selected based on previous mountain lion sightings and areas known to be frequented by mule deer (e.g., deer trails, water sources), a primary prey species of the mountain lion. No mountain lions were seen in any photographs. However, a mountain lion scrape was found near the camera at Tub Spring.

A secondary objective of the camera surveys is to detect other species using these areas to better define species distributions on the NTS. Water sources are especially important to sample because many species, including mountain lions, rely on these water sources for survival. From the photographs, BN biologists can get an idea of what species use these areas, how frequently they occur, temporal activity patterns, and relative abundance estimates. It is anticipated that six to eight additional cameras will be set up next year. 


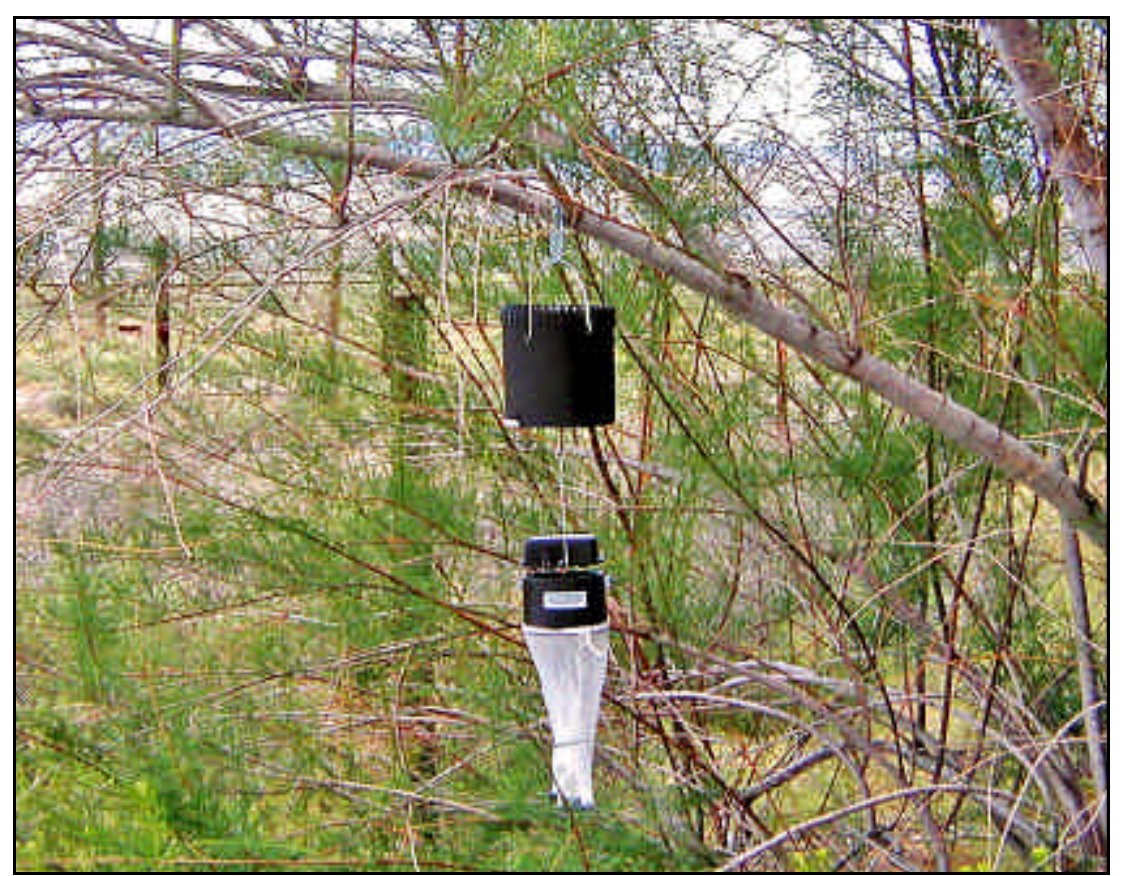

Figure 5-14. Mosquito trap set at Well 5B, Frenchman Flat. (Photo taken by Derek Hall on May 2, 2005)

Table 5-7. Results of West Nile Virus (WNV) surveillance in 2005 on the NTS.

\begin{tabular}{|lcclcc|}
\hline \hline \multicolumn{1}{c}{ Location } & Date & $\begin{array}{c}\text { Number } \\
\text { Captured }\end{array}$ & Species & WNV \\
\hline Area 6 LANL Pond & $4 / 26 / 2005$ & 0 & NA & NA \\
Area 6 LANL Pond & $5 / 2 / 2005$ & 1 & Ochlerotatus dorsalis & Negative \\
Well 5B & $5 / 2 / 2005$ & 1 & Culex tarsalis & Negative \\
Mercury SOC Park & $5 / 2 / 2005$ & 0 & NA & NA \\
Mercury SOC Park & $5 / 25 / 2005$ & 0 & NA & NA \\
Well 5B & $5 / 25 / 2005$ & 0 & NA & NA \\
Area 6 LANL Pond & $5 / 25 / 2005$ & 0 & NA & NA \\
Wilson's Pond & $7 / 13 / 2005$ & 0 & NA & NA \\
Well C1 & $7 / 13 / 2005$ & 3 & Culex tarsalis & Negative \\
Camp 17 Pond & $7 / 13 / 2005$ & 7 & Culex tarsalis & Negative \\
Mercury SOC Park & $8 / 29 / 2005$ & 0 & NA & NA \\
Yucca Playa Pond & $8 / 29 / 2005$ & 50 & Culex tarsalis & Negative \\
Yucca Playa Pond & $8 / 29 / 2005$ & 1 & Ochlerotatus dorsalis & Negative \\
Gold Meadows Spring & $8 / 29 / 2005$ & 0 & NA & NA \\
Mercury Sewage Lagoons & $9 / 26 / 2005$ & 0 & NA & NA \\
Well 3 Pond & $9 / 26 / 2005$ & 1 & Culiseta inornata & Suspect \\
Well 3 Pond & $9 / 26 / 2005$ & 1 & Culex tarsalis & Negative \\
Camp 17 Pond & $9 / 26 / 2005$ & 12 & Culiseta inornata & Negative \\
\hline \hline
\end{tabular}


Table 5-8. Locations and results of mountain lion camera surveys during 2005.

\begin{tabular}{|lll|}
\hline \hline \multicolumn{1}{c}{ Location } & \multicolumn{1}{c|}{$\begin{array}{c}\text { Dates } \\
\text { Sampled }\end{array}$} & \multicolumn{1}{c|}{ Results } \\
\hline Top of Old Rainier Mesa Road & $8 / 10-9 / 14 / 05$ & Gray or kit fox, rabbit, mourning dove \\
Gold Meadows Spring & $8 / 16-9 / 14 / 05$ & $\begin{array}{l}\text { Mule deer, coyote, horse, bat, black-tailed } \\
\text { jackrabbit, ducks }\end{array}$ \\
Captain Jack Spring & $11 / 2-12 / 6 / 05$ & Horses, mule deer \\
Whiterock Spring & $12 / 6-12 / 20 / 05$ & Mule deer, raven, passerine \\
Tippipah Spring & $12 / 6-12 / 19 / 05$ & Mule deer, raven \\
Old Area 12 Sewage Pond & $12 / 19-12 / 31 / 05$ & $\begin{array}{l}\text { Mule deer, coyotes, black-tailed jackrabbits, } \\
\text { rabbit }\end{array}$ \\
Tub Spring & $12 / 20-12 / 31 / 05$ & Mule deer, mountain lion scrape \\
\hline \hline
\end{tabular}

\subsection{Coordination with Other Wildlife Agencies and Biologists}

Dr. Courtney Conway from the University of Arizona is working on a DoD Legacy funded project evaluating migratory linkages of western burrowing owls in western North America. This involves trapping and banding burrowing owls and taking feather and blood samples. Feathers will be analyzed for specific stable isotopes to help determine migratory status and breeding and wintering locations. Dr. Conway contacted BN biologists to request their assistance in collecting samples on the NTS. Trapping results can be found in Section 5.2.1.2.

In March, a BN biologist attended the $2^{\text {nd }}$ biennial meeting of the Western Bat Working Group in Portland, Oregon and gave a presentation entitled, "Novel techniques to improve acoustic monitoring of bats on the Nevada Test Site, South-central Nevada. Several other attendees were interested in the process we developed to analyze and organize thousands of electronic files containing ultrasonic bat calls. The presentation summarized two years' worth of winter data collected from the passive acoustic monitoring system at Camp 17 Pond.

A BN biologist volunteered to help with a radiotelemetry study of bats in Northern Arizona for three nights during late June. The study was led by Dr. Carol Chambers (Northern Arizona University) and Mike Herder (Bureau of Land Management, Arizona Strip Field Office). The biologist assisted with capturing bats and radiotracking marked bats, and learned the technique for attaching radiotransmitters to bats. Experience gained during this study will be valuable for a similar study that may be conducted in the future with bats on the NTS.

Dr. Jim Simmons (Cornell University) has a contract with the U.S. Navy to conduct bioacoustical research on bats. He requested access to the NTS to study bat behavior at Camp 17 Pond with sophisticated thermal imaging and infrared cameras and acoustic bat detectors. A BN biologist escorted Dr. Simmons and his team to Camp 17 Pond on two nights in July. Successful acoustic recordings and video of bat activity were obtained.

A collaborative effort using remote, motion-activated cameras to investigate mountain lion distribution on the NTS was initiated this year in conjunction with Erin Boydston, a USGS research scientist. For details see Section 5.4 
Dr. John Hafner, a professor with Occidental College in Los Angeles, CA, is working with the Nevada Department of Wildlife to study the distribution of kangaroo mice in Nevada and surrounding states. Dr. Hafner requested access to the NTS because the dark kangaroo mouse and pale kangaroo mouse are both known to occur here. BN biologists escorted Dr. Hafner and his assistant in the field for two nights of trapping (August 1-2) and learned what types of habitat these species prefer and distinguishing characteristics of several rodent species. BN biologists continued to trap for kangaroo mice into October. Results are found in Section 5.6.1. Dr. Hafner also collected toe clippings for DNA analysis from three dark kangaroo mice specimens (\#2412J, \#2413I, and \#2413J) collected during the ENRAD project in 1959.

BN biologists assisted Phil Medica and Todd Esque, research scientists with the USGS, with small mammal trapping at the BECAMP Yucca Flat Pristine Plot (YUF001) during mid-May. The last time this site was trapped was in 1994, and Phil was interested in documenting what changes, if any, had occurred since then. Results are found in Section 5.6.2

At two active project sites, BN biologists found bird nests with eggs in them. One was a barn owl nest with two eggs at the Unicorn site in Area 6. After consulting with the FWS we got permission to take the egg to Lisa Ross with the Wild Wing Project, Inc. Lisa tried to incubate the eggs but they were not viable.

The other nest was a great-horned owl nest with four eggs located at Test Cell A in Area 25 (Figure 5-15). A FWS special agent, Eric Jumper, made a site visit to determine if proposed activities would harm the eggs. He determined that the work activities were too close to the nest. After consultations among BN biologists, Environmental Restoration personnel, Wild Wing Project and FWS, it was decided that the best option was to take the eggs to Wild Wing Project because the project could not be delayed and there were no suitable nest sites close enough to ensure the parent owls could find the nest if it was moved.

On March 21, the four eggs were removed and delivered to Lisa Ross with the Wild Wing Project in Las Vegas. Lisa incubated the eggs and three of the four eggs hatched. She used a one-winged great-horned owl, Willow, as a surrogate mother to help raise the three young (Figure 5-16). One owl was released in June 2005 at Corn Creek (Desert National Wildlife Range), one owl was released August 1, at Cane Spring on the NTS, and one owl is still at Wild Wing Project nearly ready to be released. 


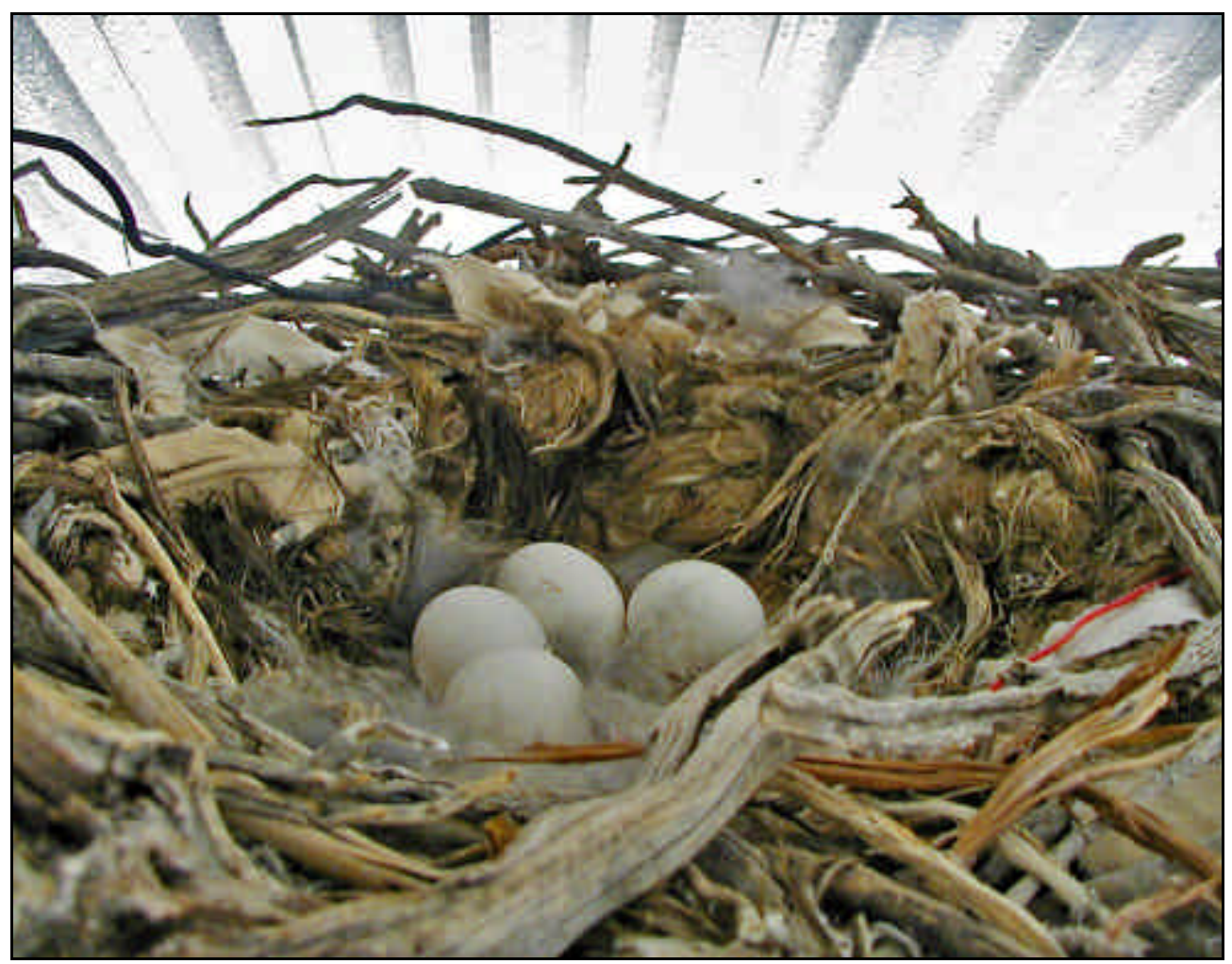

Figure 5-15. Great-horned owl nest with four eggs (Test Cell A, Area 25). (Photo taken by Derek Hall on March 7, 2005)

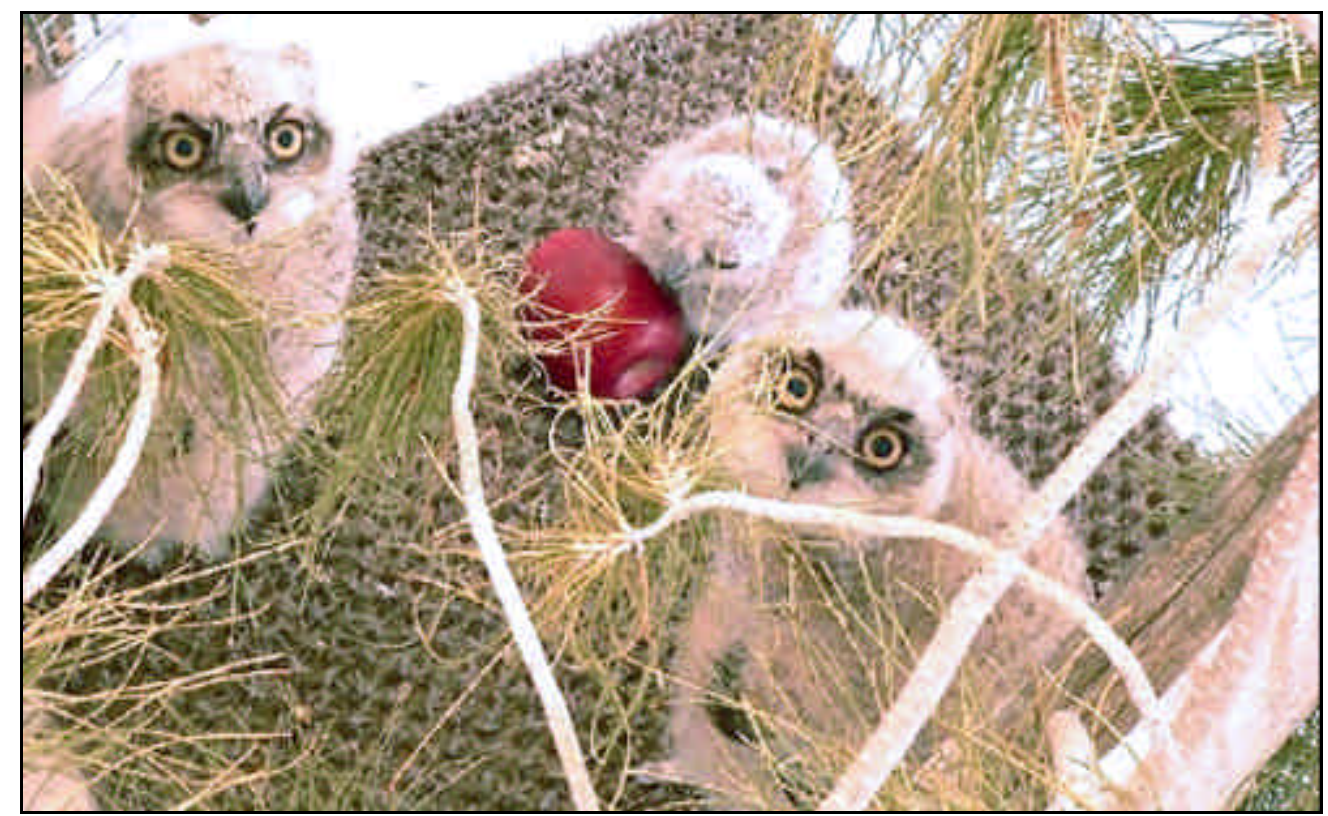

Figure 5-16. Three great-horned owl chicks at Wild Wing Project, Inc. (Photo taken by Lisa Ross in May 2005) 


\subsection{Small Mammal Surveys}

BN biologists conducted numerous small mammals trapping sessions on the NTS in 2005. The surveys were conducted for several reasons: (1) trapping where two sensitive species of rodents, dark and pale kangaroo mice, (Microdipodops megacephalus and Microdipodops pallidus) were previously captured, (2) sampling a pristine ecological plot on Yucca Flat (YUF001) to compare to results of data from 1994, the last sampling effort on that plot, and (3) collecting additional data about rodents from areas of the NTS that were never trapped.

\subsubsection{Kangaroo Mice Trapping Efforts}

With the collaboration of Dr. John Hafner, BN biologists visited habitats on the NTS where these two state-protected species of kangaroo mice were historically recorded. These habitats have been identified to be typically sandy areas located in NTS Areas 3,16,17, 18, 19, and 20. These areas were visited to examine the soils typically associated with these species and to select ten sites to trap during AugustOctober 2006. The results from the trapping sessions are shown in Tables 5-9 and 5-10. No kangaroo mice species were caught during 1,395 trap nights during 2005.

The data show that species composition in Pinyon-Juniper/Sagebrush habitats was dominated by Merriam's kangaroo rat, (Dipodomys merriam), followed by deer mouse (Peromyscus maniculatus) and Chisel-toothed kangaroo rat, (D. microps). All together, we captured 11 species at 9 sites (Table 5-9). The Great Basin pocket mouse (Perognathus parvus) was the fourth most abundant and widespread species captured (31 individuals at 8 sites). The Desert woodrat (Neotoma lepida) was very abundant (26 individuals) and was captured along disturbed roadside habitats in Area 20.

Extensive trapping effort was conducted in one unique habitat of sand dunes near Beatley Plot 65 in Area 17 (Table 5-10). We found some notable differences in species composition here, most individuals (16) of Ord's Kangaroo rat (D. ordii) were trapped here (Table 5-10), compared to 9 other sites trapped, where only 4 individuals of this species were caught at one site. Merriam's kangaroo rat (D. merriami )was the dominant species (51.7 percent) followed by deer mice (13.4 percent) in the sand dunes habitat. Comparing our overall results to Beatley's Plot 65 data from 1964-68, we found similarities in the species caught, namely the dominant species was still Merriam's kangaroo rat, followed by similar percentages of deer mouse and chisel-toothed kangaroo rat, however, we caught fewer Ord's kangaroo rat in 2005 on a percentage basis (7.1 percent) than were caught from 1964-68 (26 percent).

\subsubsection{YUF001 Pristine Ecological Plot}

BN scientists also collaborated with USGS scientists (Phil Medica and Todd Esque) to sample a permanent pristine ecological plot (YUF001) on the southern end of Yucca Flat. This plot was set up in 1987 under a previous ecological monitoring program (Basic Environmental Compliance and Monitoring Program [BECAMP]) to monitor trends in the flora and fauna populations over time. This plot was last sampled in 1994 under the goals of BECAMP. Our methods involved 4 consecutive trap nights on a 12 -station by 12 -station staked-trapping grid containing 144 stations with $15 \mathrm{~m}$ spacing ( $2.72 \mathrm{ha}$ ) and two traps per station (i.e., a total of 288 traps per night). Animals were caught and marked with a different indelible colored pen on each night of the first three-night trapping nights, therefore, the total number of individuals could be counted after 4 days of trapping. Results of the trapping sessions are shown in Table 5-11. Overall, 327 individual small mammals comprised of 8 species were trapped in 2005 on the plot with an overall trap success of 33.5 percent. Percent composition indicated a dominance of Merriam's and chisel-toothed kangaroo rats, followed by deer mouse and little pocket mouse (Perognathus longimembris). 
Table 5-9. Results of small-mammal trapping on sandy-soil habitats in 2005.

(Percent composition is shown with the numbers of animals in parenthesis)

\begin{tabular}{|c|c|c|c|c|c|c|c|c|c|c|}
\hline Locations: & $\begin{array}{l}\text { East section } \\
\text { of Pahute } \\
\text { Mesa Road }\end{array}$ & $\begin{array}{c}\text { Middle } \\
\text { section of } \\
\text { Pahute } \\
\text { Mesa Road }\end{array}$ & $\begin{array}{c}\text { West end } \\
\text { of Pahute } \\
\text { Mesa Road }\end{array}$ & 19-02 Road & $\begin{array}{c}\text { North of } \\
\text { Camp } 17 \\
\text { Pond }\end{array}$ & $\begin{array}{c}\text { West of } \\
\text { PMR/SWR } \\
\text { Intersection }\end{array}$ & $\begin{array}{c}\text { Camp } 17 \\
\text { Area } \\
\text { Disturbed }\end{array}$ & $\begin{array}{c}\text { Sugar Loaves } \\
\text { adjacent to } \\
\text { Pahute Mesa } \\
\text { Road }\end{array}$ & $\begin{array}{c}\text { Sugar Loaves } \\
\text { hills east of } \\
\text { Pahute Mesa } \\
\text { Road }\end{array}$ & $\begin{array}{c}\text { Total } \\
\text { Numbers }\end{array}$ \\
\hline NTS Area: & 20 & 20 & 20 & 19 & 19 & 18 & 18 & 17 & 17 & \\
\hline Date Sampled: & $8 / 1 / 2005$ & $8 / 1 / 2005$ & $8 / 1 / 2005$ & $8 / 2 / 2005$ & $8 / 2 / 2005$ & $8 / 2 / 2005$ & $10 / 25 / 2005$ & $10 / 25 / 2005$ & $10 / 25 / 2005$ & \\
\hline \multicolumn{11}{|l|}{ Species: } \\
\hline $\begin{array}{l}\text { Antelope ground squirrel (Ammospermophilus } \\
\text { leucurus) }\end{array}$ & 0 & $3.3(1)$ & $5.3(1)$ & 0 & 0 & 0 & $1.6(1)$ & $24.1(7)$ & 0 & 10 \\
\hline Chisel-toothed kangaroo rat (Dipodomys microps) & $18.2(12)$ & $3.3(1)$ & $26.3(5)$ & 0 & $11.1(4)$ & $21.4(6)$ & $4.8(3)$ & $13.8(4)$ & $21.7(5)$ & 40 \\
\hline Deer mouse (Peromyscus maniculatus) & $39.4(26)$ & $20(6)$ & $21(4)$ & $63.4(26)$ & $2.7(1)$ & $3.6(1)$ & $27.4(17)$ & $20.7(6)$ & $13(3)$ & 90 \\
\hline Desert woodrat (Neotoma lepida) & $18.2(12)$ & $33.3(10)$ & $21(4)$ & $7.3(3)$ & 0 & 0 & 0 & $3.4(1)$ & $4.3(1)$ & 31 \\
\hline Great Basin pocket mouse (Perognathus parvus) & $3.0(2)$ & $10(3)$ & $5.3(1)$ & $12.2(5)$ & $33.3(12)$ & 0 & $6.4(4)$ & $6.9(2)$ & $8.6(2)$ & 31 \\
\hline $\begin{array}{l}\text { Long-tailed pocket mouse (Chaetodipus } \\
\text { formosus) }\end{array}$ & $9.1(6)$ & $13.3(4)$ & 0 & $4.9(2)$ & 0 & $3.6(1)$ & 0 & 0 & 0 & 13 \\
\hline Little pocket mouse (Perognathus Iongimembris) & 0 & 0 & 0 & 0 & 0 & $7.1(2)$ & $1.6(1)$ & 0 & 0 & 3 \\
\hline Merriam's kangaroo rat (Dipodomys merriami) & $7.6(5)$ & $6.7(2)$ & $10.5(2)$ & $2.4(1)$ & $47.2(17)$ & $64.2(18)$ & $53.2(33)$ & $27.5(8)$ & $47.8(11)$ & 97 \\
\hline Ord's kangaroo rat (Dipodomys ordii) & 0 & 0 & 0 & $9.7(4)$ & 0 & 0 & 0 & 0 & 0 & 4 \\
\hline $\begin{array}{l}\text { Western harvest mouse (Reithrodontomys } \\
\text { megalotus) }\end{array}$ & $3.0(2)$ & 0 & 0 & 0 & 0 & 0 & $1.6(1)$ & 0 & 0 & 3 \\
\hline $\begin{array}{l}\text { Southern grasshopper mouse (Onychomys } \\
\text { torridus) }\end{array}$ & $1.5(1)$ & $6.7(2)$ & $10.5(2)$ & 0 & $5.5(2)$ & 0 & $3.2(2)$ & 0 & $4.3(1)$ & 10 \\
\hline Dipodomys spp & 0 & 0 & 0 & 0 & 0 & 0 & 0 & $3.4(1)$ & 0 & 1 \\
\hline Unknown species & 0 & $3.3(1)$ & 0 & 0 & 0 & 0 & 0 & 0 & 0 & 1 \\
\hline Total Number: & 66 & 30 & 19 & 41 & 36 & 28 & 62 & 29 & 23 & 334 \\
\hline Species Richness (Total Number of Species): & 8 & 8 & 7 & 6 & 5 & 5 & 8 & 6 & 6 & \\
\hline Trap Nights: & 200 & 100 & 100 & 100 & 100 & 100 & 100 & 50 & 50 & \\
\hline Trap Success (\%): & 33 & 29 & 19 & 41 & 36 & 28 & 62 & 58 & 46 & \\
\hline
\end{tabular}


Table 5-10. Total numbers of small mammals caught daily on or near Beatley Plot 65 in Area 17 of the NTS.

\begin{tabular}{|c|c|c|c|c|c|c|c|c|c|c|c|}
\hline \multirow{2}{*}{$\begin{array}{l}\text { Locations in Area 17: } \\
\text { Date Sampled: }\end{array}$} & \multirow{2}{*}{$\begin{array}{c}\text { East Dunes" } \\
8 / 2 / 2005\end{array}$} & \multicolumn{2}{|c|}{ North Dune Area } & \multicolumn{2}{|c|}{ South Dune Area } & \multirow{2}{*}{$\begin{array}{c}\begin{array}{c}\text { Non-Dune } \\
\text { Area }\end{array} \\
10 / 26 / 2005 \\
\end{array}$} & \multicolumn{2}{|c|}{ Beatiey Plot Area } & \multirow{2}{*}{$\begin{array}{c}\begin{array}{c}\text { Hill West of } \\
\text { Beatley Plot }\end{array} \\
10 / 27 / 2005\end{array}$} & \multirow{2}{*}{ Totals } & \multirow{2}{*}{ Percent } \\
\hline & & $10 / 26 / 2005$ & $10 / 27 / 2005$ & $10 / 26 / 2005$ & $10 / 27 / 2005$ & & $10 / 26 / 2005$ & $10 / 27 / 2005$ & & & \\
\hline \multicolumn{12}{|l|}{ Species } \\
\hline $\begin{array}{l}\text { Antelope ground squirrel (Ammospermophilus } \\
\text { leucurus) }\end{array}$ & 3 & 2 & 0 & 0 & 1 & 2 & 1 & 2 & 3 & 14 & 6.3 \\
\hline Chisel-toothed kangaroo rat (Dipodomys microps) & 1 & 4 & 5 & 1 & 2 & $3:$ & 0 & 1 & 3 & 20 & 8.9 \\
\hline Deer mouse [Peromyscus maniculatus) & 2 & 1 & 1 & 6. & 8 & 2 & 3 & 7 & 0 & 30 & 13,4 \\
\hline Desert pack rat (Neotoma lepida) & 2 & 1 & 0 & 1 & 0 & 3 & 0 & 1 & 0 & 8 & 36 \\
\hline Merriam's kangarco rat (Dipodomys meriami) & 17 & 13 & 6 & 9 & 10 & 12 & 17 & 13 & 19 & 116 & 51.7 \\
\hline Ord Kangaroo rat (Dipodamys ordii) & 3 & 0 & 3 & 4 & 4 & 0 & 1 & $\theta$ & 1 & 16 & 7,1 \\
\hline Pinion Mouse (Feromyscus trueii) & 0 & 0 & 0 & 0 & 0 & 1 & 0 & 0 & 0 & 1 & 0.4 \\
\hline Southem Grasshopper mouse (Onychomys tomdus) & 1 & 4 & 1 & 0 & 2 & 1 & 4. & 2. & 2 & 17 & 7.6 \\
\hline Dipodomys spp & 0 & 0 & 0 & 0 & 0 & 0 & 0 & 0 & 2 & 2 & 1.0 \\
\hline Total Number: & 29 & 25 & 16 & 21 & 27 & 24 & 28 & 26 & 30 & 224.00 & \\
\hline Species Richness (Total Number of Species): & 7 & 6 & 5 & 5 & 6. & 7 & 5 & 6 & 5 & 5.88 & \\
\hline Trap Nights: & 100 & 50 & 50 & 50 & 50 & 45 & 50 & 50 & 50 & 495.00 & \\
\hline Trap Success $(\%)$ : & 29 & 50 & $32^{\mathrm{t}}$ & 42 & 54 & 53 & 52 & 52 & 70 & 50.25 & \\
\hline
\end{tabular}

"Mabitat is adjacent and similar to North and South Dune Areas

Lower trap success was due to paper batting placed in traps to insulate animals from the cold 
Table 5-11. YUF001 Plot trapping results from May 2005 compared to May 1994.

(New animals were those unmarked on the day they were caught)

\begin{tabular}{|c|c|c|c|c|c|c|}
\hline \multirow[b]{2}{*}{ Dates: } & \multicolumn{4}{|c|}{ Number of New Animals } & \multirow{2}{*}{$\begin{array}{c}2005 \\
\text { Percent } \\
\text { (Total) }^{\mathrm{a}}\end{array}$} & \multirow{2}{*}{$\begin{array}{c}1994 \\
\text { Percent } \\
\text { (Total) }^{\mathrm{b}}\end{array}$} \\
\hline & $5 / 13 / 06$ & $5 / 14 / 05$ & $5 / 15 / 05$ & $5 / 16 / 05$ & & \\
\hline \multicolumn{7}{|l|}{ Species } \\
\hline Deer mouse (Peromyscus maniculatus) & 8 & 10 & 1 & 2 & $15.6(21)$ & $1.1(2)$ \\
\hline Desert woodrat (Neotoma lepida) & 1 & 0 & 0 & 1 & $1.5(2)$ & 0 \\
\hline Great Basin kangaroo rat (Dipodomys microps) & 38 & 7 & 7 & 7 & $43.7(59)$ & $64.5(111)$ \\
\hline Little pocket mouse (Perognathus longimembris) & 6 & 8 & 3 & 1 & $13.3(18)$ & $5.2(9)$ \\
\hline Long-tailed pocket mouse (Chaetodipus formosus) & 0 & 0 & 0 & 0 & 0 & $0.6(1)$ \\
\hline Merriam's kangaroo rat (Dipodomys merniami) & 11 & 6 & 2 & 5 & $17.8(24)$ & $26.7(46)$ \\
\hline Southern grasshopper mouse (Onychomys torridus) & 6 & 3 & 1 & 1 & $8.1(11)$ & $0.6(1)$ \\
\hline Western harvest mouse (Reithrodontomys megalotis) & 0 & 0 & 0 & 0 & 0 & $1.2(2)$ \\
\hline Total Animals (marked): & 70 & 34 & 14 & 17 & 135 & 172 \\
\hline Total Caught/Day during 2005: & 75 & 79 & 87 & 86 & 327 & 425 \\
\hline Species Richness (Total Number of Species): & 6 & 5 & 5 & 6 & 6 & 7 \\
\hline Trap Nights: & 288 & 288 & 288 & 288 & 1152 & 864 \\
\hline Trap Success $(\%)$ : & 26.0 & 27.4 & 30.0 & 29.9 & 28.3 & 49.2 \\
\hline \multicolumn{7}{|c|}{${ }^{3}$ Total individuals captured and data summary during 2005 , based on 4 trap nights } \\
\hline \multicolumn{7}{|c|}{${ }^{b}$ Total individuals captured and data summary during 1994, based on 3 trap nights; data from Hunter et.al., (1995) } \\
\hline \multicolumn{7}{|c|}{2005 Nalve Density $=135 / 3.8 \mathrm{ha}=35.5 /$ ha, using a $15-\mathrm{m}$ buffer around plot } \\
\hline
\end{tabular}


There were differences in species composition between 1994 and 2005. Data from 1994 showed higher numbers of chisel-toothed kangaroo rats and Merriam's kangaroo rat caught compared to 2005. Also higher numbers of three species (deer mouse, little pocket mouse, and southern grasshopper mouse [Onychomys torridus]) were present in 2005 compared to 1994.

Employing a 15-m buffer area around the plot (CRWMS M\&O 1997) allowed for movements of animals on and off the plot edge. The overall "naive density" calculated from total numbers of individuals/area (i.e., 135/3.8 ha) was 35.5 animals per ha for 2005. This compares to data from 1994 (Saethre, 1995) showing a decrease in density from 1994 (45.3/ha) (see Table 5-11 shown previously). Numbers of the little pocket mouse had declined greatly and had still not recovered from the high population levels shown during 1987-91 on this plot (Saethre, 1995).

\subsection{Wild Horses}

Horse monitoring continued this year to provide information on the abundance, recruitment (i.e., survival of horses to reproductive age), and distribution of the horse population on the NTS. Monitoring of individual horses at NTS began in 1989. In 2005, BN biologists determined horse abundance and recorded horse sign along roads. Also, selected natural and human-made water sources were visited in the summer to determine their influence on horse distribution and movements and document the impact horses are having on NTS wetlands. Information on abundance and recruitment during 1990-1998 is summarized in Greger and Romney (1999).

\subsubsection{Abundance Survey}

A count of individual horses was taken to estimate abundance. The count was conducted during 15 nonconsecutive days between June and December. A standard road course was driven to locate and identify horses. Individuals were identified by their unique physical markings (facial blazes), and classified as foal, yearling, or older (= 2 years old) (Figure 5-17). The direct population count in 2005 was 49 individuals not including foals (Table 5-12). Five horse bands (composed of stallions, subordinate males, females, and their offspring) were detected this year. Bands observed ranged in size from 3 to 13 individuals excluding foals. Five foals were observed with their mares from June-December. The population showed a moderate increase in number over last year due to the recent survival of several younger aged horses (yearling to two-year olds).

\subsubsection{Horse Population Trends and Predation}

The historical trend in the NTS horse population has generally been downward from 1994 to 2002 (Table 5-12). Only 17 yearling horses have been observed in the population from 1995 through 2003. The overall population declines from 1995 to 1998 appear to be the result of poor foal survival and no immigration of new adults into the population. Mountain lion and possibly coyote predation are hypothesized as the most reasonable causes for this population reduction. Evidence for this is cited from (Greger and Romney 1999) where more than 52 apparently healthy foals were missing over short periods of time (days to months) from 1990-1994. In addition, no yearlings observed from 1995-1998 suggest foal survival was negligible during these years (no surveys for foals were conducted in 1995-1997) (Figure 5-18). These losses are most likely due to predation. Older male horses have tended to disappear from the population over time, with only eight males presently observed in the NTS population this year (see Table 5-12 shown previously). These losses could be due to predation, losses from old age, or injuries inflicted from fighting or disease. During this same time (1989-1994), deer counts on the NTS $($ mean total count $=91.2$ deer $)$ compared to $1999-2000$ (mean total count $=27.2$ deer $)$ per spotlighting session ( 3 nights) were significantly lower across years $(t=4.16$, d.f. $=7, p=0.002)$. Since deer are the 
normal prey for mountain lions, a decreased deer population is consistent with higher predation of lions on horses. Unidentified remains of horses (bones and hair) are commonly found in heavily used areas around springs and suggest that the loss of adults was probably due to mortality as opposed to emigration.

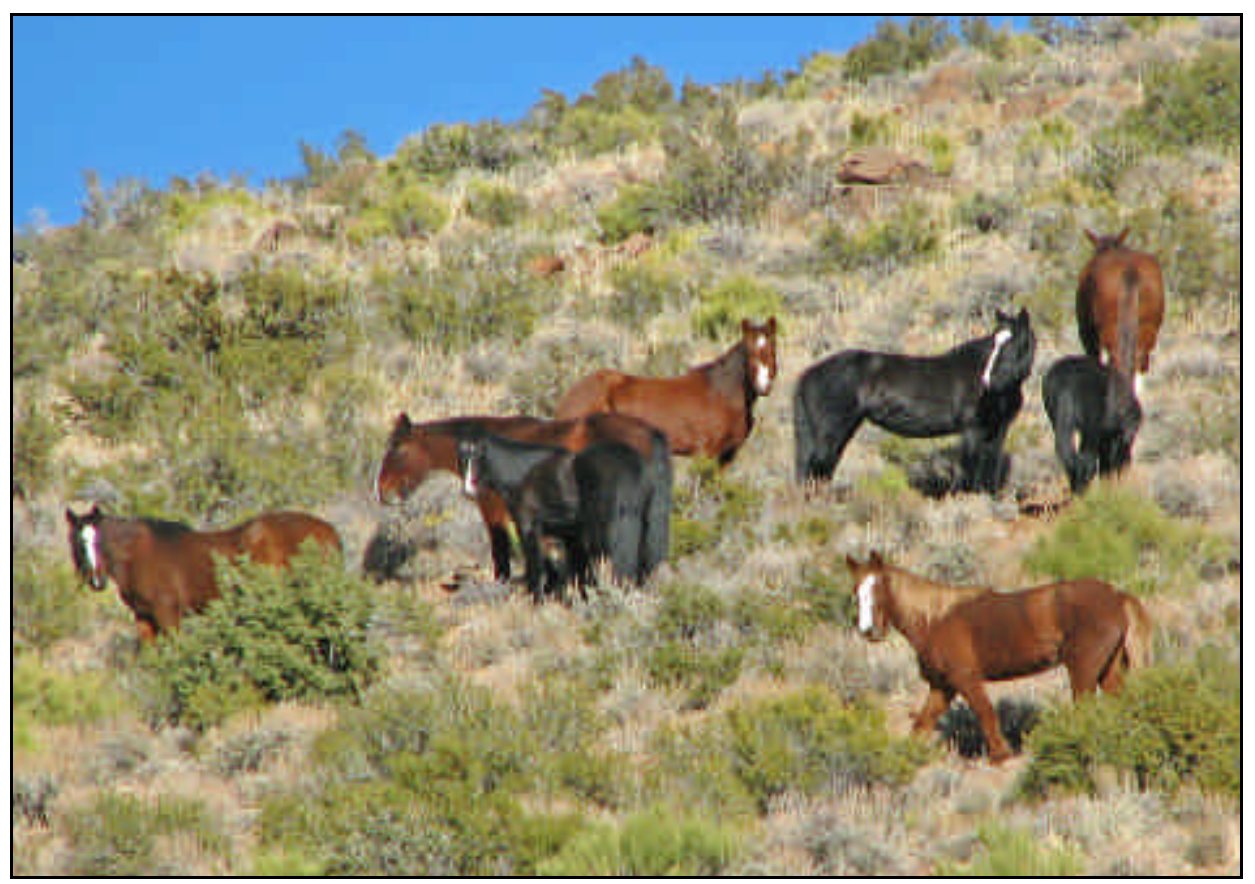

Figure 5-17. Horse band near Captain Jack Spring. (Photo taken by Derek Hall on November 30, 2005.)

Table 5-12. Number of individual horses observed on the NTS by age class, gender, and year.

\begin{tabular}{|c|c|c|c|c|c|c|c|c|c|c|c|c|c|c|c|c|c|c|c|c|}
\hline \multirow[b]{2}{*}{ Age Class } & \multicolumn{20}{|c|}{ Number of individuals Observed by Year } \\
\hline & \multicolumn{2}{|c|}{1996} & \multicolumn{2}{|c|}{1997} & \multicolumn{2}{|c|}{1998} & \multicolumn{2}{|c|}{1999} & \multicolumn{2}{|c|}{2000} & \multicolumn{2}{|c|}{2001} & \multicolumn{2}{|c|}{2002} & \multicolumn{2}{|c|}{2003} & \multicolumn{2}{|c|}{2004} & \multicolumn{2}{|c|}{2005} \\
\hline Foals & \multicolumn{2}{|c|}{1} & \multicolumn{2}{|c|}{3} & \multicolumn{2}{|c|}{8} & \multicolumn{2}{|c|}{5} & \multicolumn{2}{|c|}{11} & \multicolumn{2}{|c|}{11} & \multicolumn{2}{|c|}{5} & \multicolumn{2}{|c|}{6} & \multicolumn{2}{|c|}{5} & \multicolumn{2}{|c|}{5} \\
\hline Yearlings & \multicolumn{2}{|c|}{0} & \multicolumn{2}{|c|}{0} & \multicolumn{2}{|c|}{0} & \multicolumn{2}{|c|}{2} & \multicolumn{2}{|c|}{4} & \multicolumn{2}{|c|}{2} & \multicolumn{2}{|c|}{0} & & 8 & \multicolumn{2}{|c|}{9} & \multicolumn{2}{|c|}{6} \\
\hline & $M^{2}$ & $F^{a}$ & M & $\mathrm{F}$ & M & $\mathrm{F}$ & M & $\mathrm{F}$ & M & $\mathrm{F}$ & M & $\mathrm{F}$ & M & $\mathrm{F}$ & M & $\mathrm{F}$ & M & $\mathrm{F}$ & M & $\mathrm{F}$ \\
\hline 2-Year Olds & 0 & 1 & 0 & 0 & 0 & 0 & 0 & 0 & $2^{b}$ & 0 & 2 & 2 & 0 & 2 & 0 & 0 & 4 & 4 & 5 & 4 \\
\hline 3-Year Olds & 0 & 0 & 0 & 1 & 0 & 0 & 0 & 0 & 0 & 0 & 0 & 0 & 2 & 2 & 0 & 2 & 0 & 0 & 4 & 4 \\
\hline Adults ( $>3$-Year Oids) & 21 & 24 & 19 & 20 & 16 & 21 & 11 & 20 & 13 & 21 & 11 & 20 & 8 & 19 & 8 & 20 & 6 & 21 & 5 & 21 \\
\hline Total (excluding foals) & 4 & & 4 & & 3 & & 3 & & 3 & & 3 & & & 3 & & 8 & & 14 & & 9 \\
\hline
\end{tabular}

" $M=$ male, $F=$ female

${ }^{b}=$ number found dead 


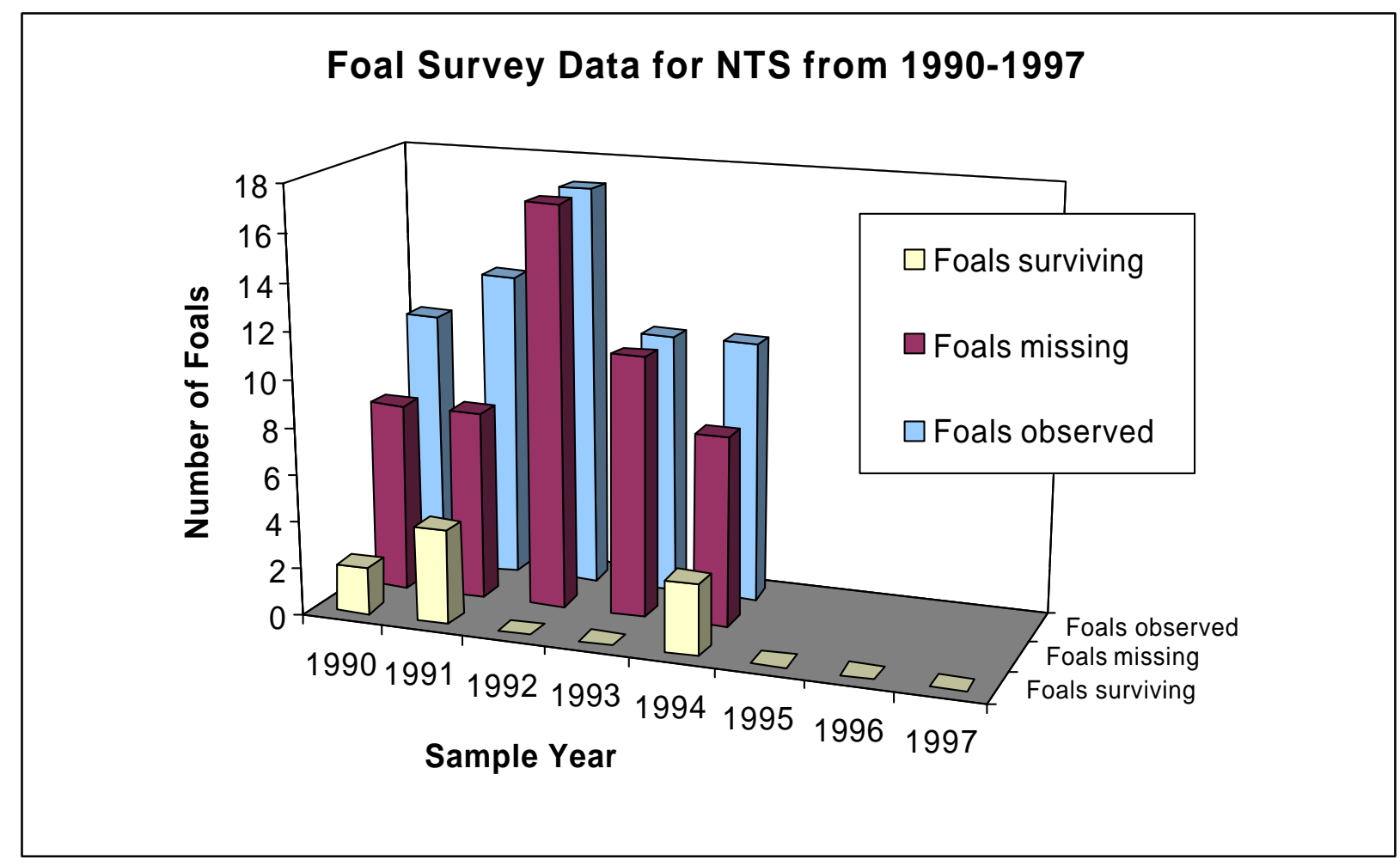

Figure 5-18. Foals observed, missing foals, and foals that survived from 1990 to 1997.

During 2004-2005 the horse population appears to be making a small comeback as shown by moderate numbers of young horses (yearling and 2-year olds) being recruited to the population (Figure 5-19). This may be related to two good to above average years of moisture during this time. We have also observed increased ungulate sign around springs, and have observed moderately large groups of antelope and deer (10-20 or more) in various regions of the NTS (Figure 5-20). We therefore have some evidence that the prey base for mountain lions has increased over the last few years. Spotlighting counts will be initiated in the fall of 2006 to evaluate if this trend is reversing. If more deer are available as prey to lions and other carnivores this may explain increased survival of young horses as predation pressure may be spread out across a more numerous prey base. Prey switching has been suggested for a population of lions in the Montgomery Peaks area of Nevada, where increased numbers of available deer seasonally shifted lion predation away from horses to deer (Turner et. al., 1991).

\subsubsection{Annual Range Survey}

During 2005, selected roads were driven within and along the boundaries of the suspected annual horse range and all fresh sign (estimated to be $<1$ year old) located on and adjacent to the roads were recorded. Eight days of effort were expended for the road surveys. Horse sign data collected during the road surveys and horse use at natural and human-made water sources indicate that the 2005 NTS horse range includes Gold Meadows, Yucca Flat, Eleana Range, southwest foothills of the Eleana Range, and southeast Pahute Mesa (Figure 5-21). Overall, the annual horse range appears to be similar to previous years and totals approximately $301 \mathrm{~km}^{2}\left(116 \mathrm{mi}^{2}\right)$. During the summer, horses are dependent on Captain Jack Spring, the only known water source in the Eleana Range. Several human-made water sources on Yucca Flat have been removed in past years, and the increased distances horses must travel back and forth to Captain Jack Spring probably limits the herds' grazing range to the north and east. In addition, the risk of mountain lion predation is greater for those horses returning to the Eleana Range to drink. 
As in previous years, the horse herd appears to consist of two components; one larger group of horses (about 30-33 individuals) comprised of four bands that spends summers west of the Eleana Range and two bands (13-16 individuals) that summer east of the Eleana Range on Yucca Flat. These groups of horses probably intermix during the winter in the Eleana Range. 


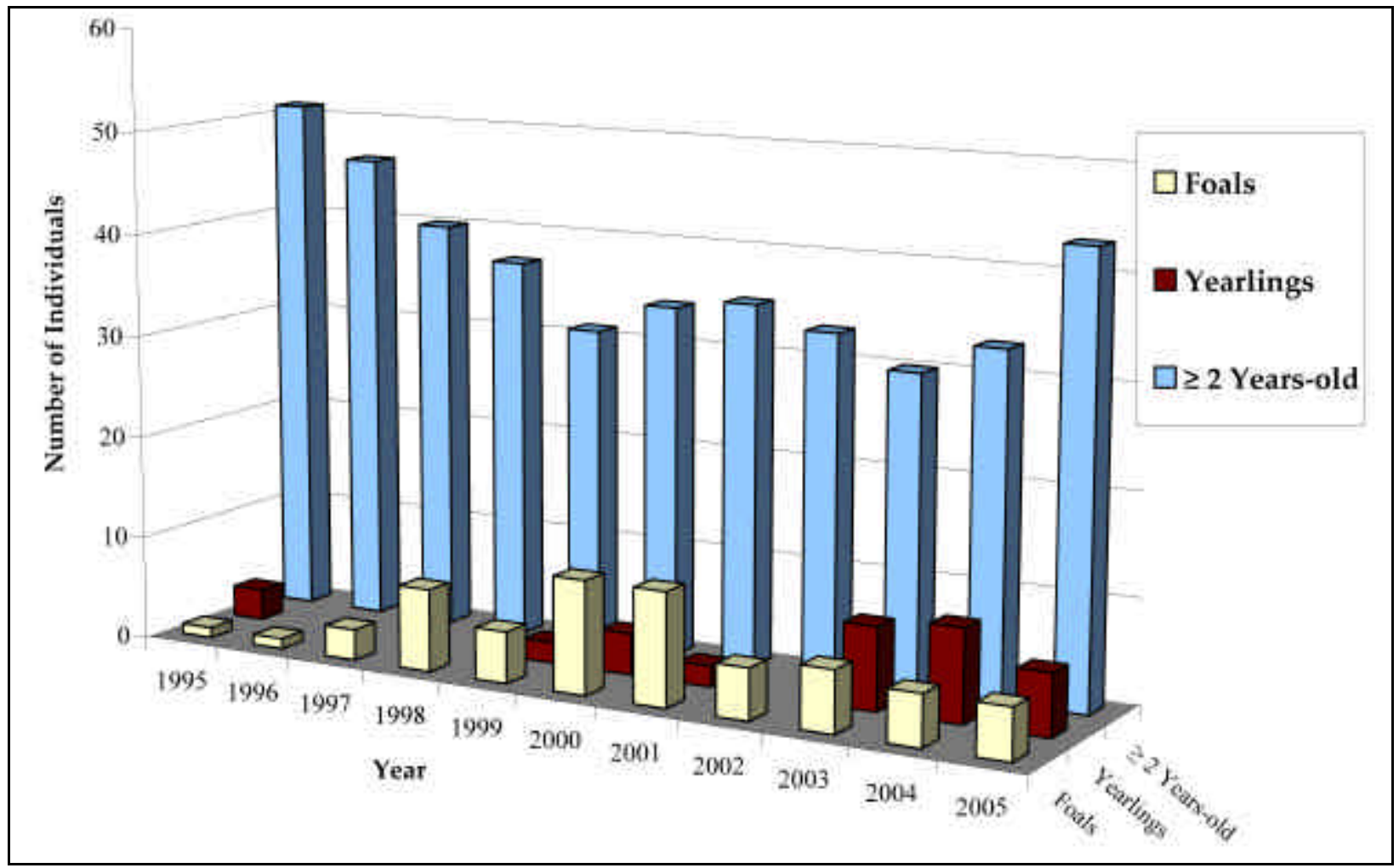

Figure 5-19. Trends in the age structure of the horse population from 1995 to 2005.

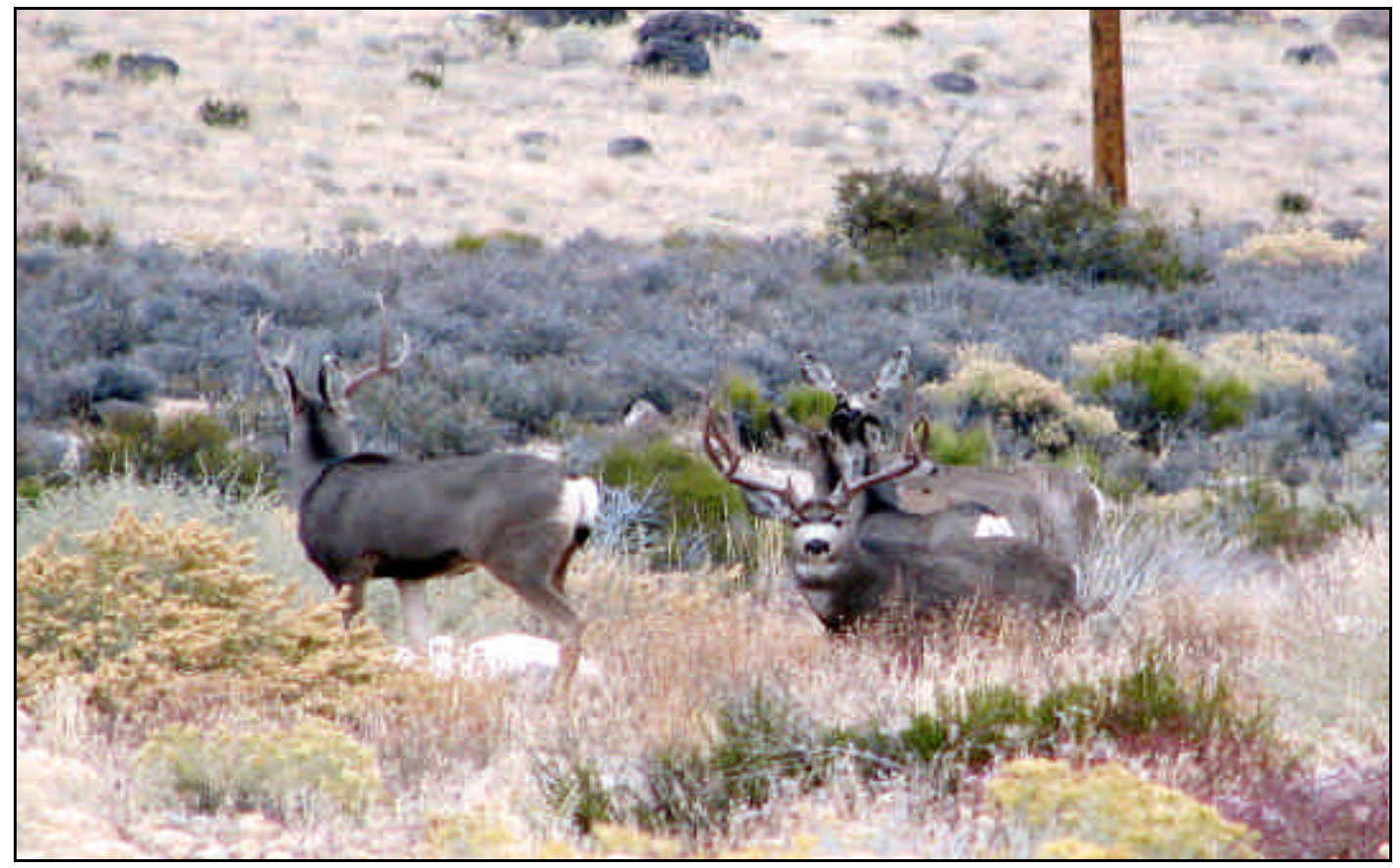

Figure 5-20. Mule deer near Egg Point Burn in Area 12. (Photo taken by Derek Hall on November 8, 2005.) 


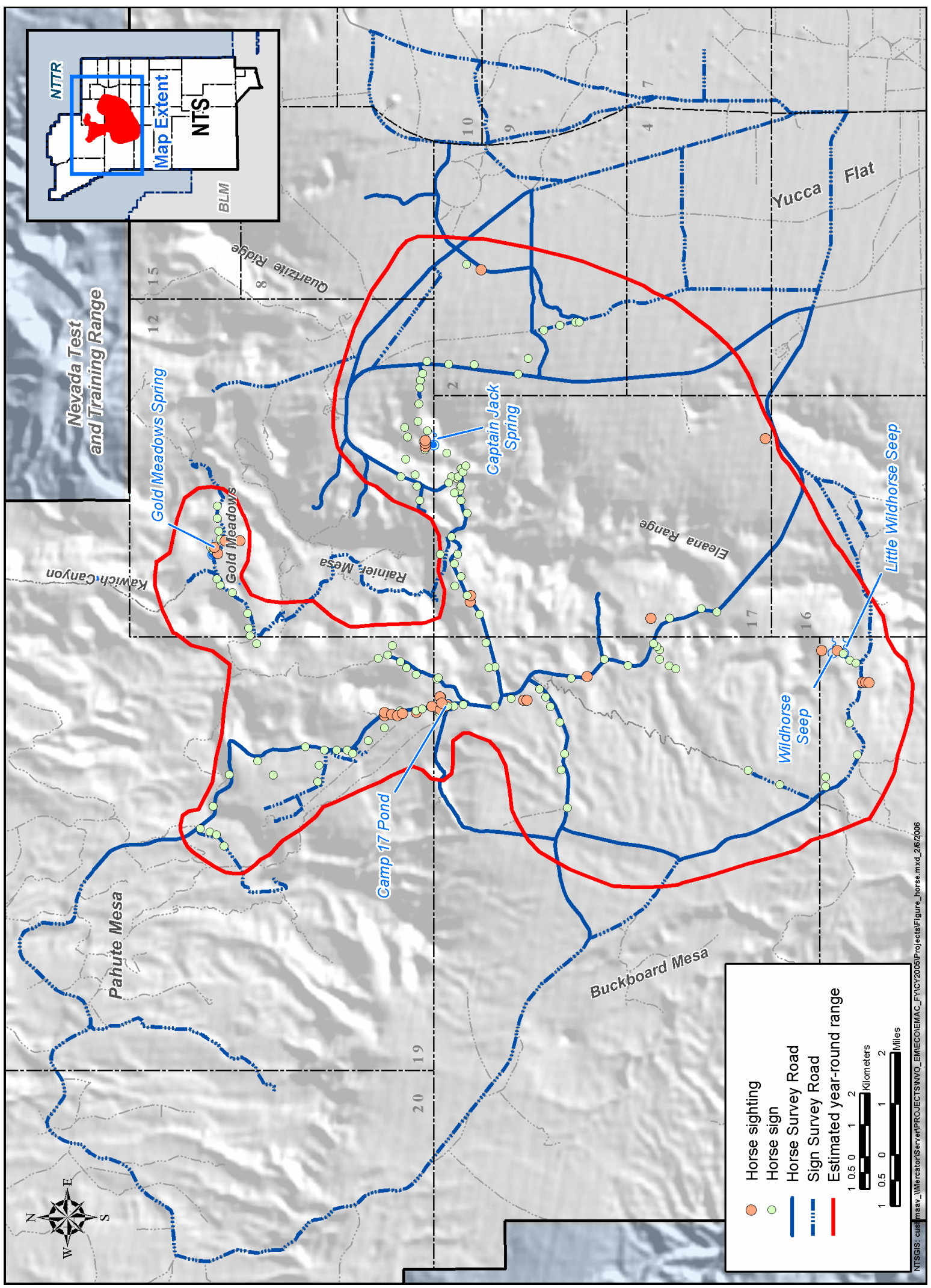

Figure 5-21. Feral horse sightings and horse sign observed on the NTS during 2005. 


\subsubsection{Horse Use of NTS Water Sources}

The NTS horse population is dependent on several natural and human-made water sources in Areas 18, 12, and 30 during different seasons (Figure 5-21). Human-made water source availability has not changed greatly over the last eight years. Wildhorse and Little Wildhorse seeps, both located in Area 30, are important winter-spring water sources. Two other natural water sources (Captain Jack Spring in Area 12, Gold Meadows Spring in Area 12) and one human-made pond (Camp 17 Pond in Area 18) were used heavily as in past years. Overall, Captain Jack Spring and Camp 17 Pond were the most important summer-fall water sources for horses based on the observed heavy activity. Horses often use ephemeral water sources in winter such as rock tanks and natural pools that collect water from rain and snowmelt. They appear to be much less dependent on human-made sources in winter. Gold Meadows sump became dry in October of 2005 as in the previous year. This causes horses to move to lower elevations closer to Camp 17 pond throughout the fall.

As in past years, none of the plastic-lined sumps within or near the horse range (see Section 5.3.3) was used by horses this year. No horse signs have ever been found at these ponds, suggesting that horses do not drink from them.

\subsection{Birds}

\subsubsection{Raptors}

Several raptors occur and breed on the NTS. Some are sensitive species and all are protected/regulated under the Migratory Bird Treaty Act and/or Nevada state law. Raptors include all vultures, hawks, kites, eagles, ospreys, falcons, and owls. Because these birds occupy high trophic levels of the food chain, they are regarded as indicators of ecosystem stability and health. Including the western burrowing owl, there are nine raptors which are known to breed on the NTS (Greger and Romney, 1994).

In 2005, no surveys to locate new raptor nests were conducted, however opportunistic sightings were recorded throughout the year. Two active raptor nests were found during surveys of buildings scheduled for demolition (see Section 2.0). One active Great-horned owl nest was located in area 6 in Building 6623 where 3 young were fledged. There were no human impacts observed to this nest site.

Opportunistic sightings of raptors were common this year and included red-tailed hawks (Buteo jamaicensis), turkey vultures (Cathartes aura), golden eagles, American kestrels and prairie falcons. Many of these individuals are commonly seen perching on utility poles on Frenchman and Yucca Flat. Other species of raptors such as Cooper's hawks (Accipter cooperii) and red-tailed hawks have been observed around water sources (see Section 5.9.2) near Rainier Mesa. Short-eared owls (Asio flammeus) were observed in three locations on the NTS this year representing the first observations of this species in over 20 years. Eight short-eared owls were observed along Orange road on Yucca Flat during Au gust this year. A large group (10-15) of short-eared owls was observed roosting in saltcedar trees (Tamarix ramosissima) on Frenchman playa during November, and 1 short-eared owl was observed at Whiterock Springs in December 2005. Raptor breeding will be periodically monitored at least once every five years.

\subsubsection{Bird Mortality}

Bird mortality is recorded as a measure of potential impacts that NNSA/NSO activities may have on protected bird species (Table 5-13). Twelve bird mortalities were recorded in 2005. Two of the primary causes of bird mortality were road kill and electrocution. In one particular case, the electrocution of both two common raven adults occurred at the nest site as a result of their wings coming in contact with power 
lines. Several raptor species were recorded dead on NTS this calendar year including a turkey vulture and a golden eagle. In early December, a juvenile golden eagle was grounded and injured in Frenchman Flat. It was captured and taken to the North Las Vegas animal hospital for examination. It was euthanized because the damage to its wing was too severe to repair. An injured red tailed-hawk from Area 25 was transported and cared for by the Wild Wing Project, Inc. and later released near Corn Creek on the Desert National Wildlife Range. Overall impacts to raptor populations from NNSA/NSO activities at NTS are very low.

Table 5-13. Records of bird mortality and injuries on the NTS during 2005.

\begin{tabular}{|c|c|c|c|c|}
\hline \multirow[b]{2}{*}{ Species } & \multicolumn{3}{|c|}{ Cause of Death } & \multirow{2}{*}{ Injured $^{\mathrm{a}}$} \\
\hline & Electrocution & Roadkill & Unknown & \\
\hline Barn owl (Tyto alba) & & & & $1^{b}$ \\
\hline Common loon (Gavia immer) & & & 1 & \\
\hline Common raven (Corvus corax) & 3 & 1 & & \\
\hline Crissal thrasher (Toxostoma crissale) & & 1 & & \\
\hline Golden eagle (Aquila Chrysaetos) & & 1 & & $1^{\mathrm{b}}$ \\
\hline Loggerhead shrike (Lanius ludovicianus) & & 1 & & \\
\hline Red-tailed hawk (Buteo Jamaicensis) & & & & $1^{\mathrm{c}}$ \\
\hline Turkey vulture (Cathartes aura) & & 1 & & \\
\hline $\begin{array}{l}\text { White-crowned sparrow (Zonotrichia } \\
\text { leucophrys) }\end{array}$ & & 1 & & \\
\hline Total: & 3 & 6 & 1 & 3 \\
\hline
\end{tabular}

anjured birds were transported to

Las Vegas, Nevada for treatment

${ }^{b}$ Injuries were so severe that the bird was euthanized

${ }^{\mathrm{c}}$ Rehabilitated and released at Corn Creek at the Desert National Wildlife Range

\subsection{Wetlands and Wildlife Water Sources}

Natural wetlands (e.g., vegetated seeps and springs) and human-made water sources (e.g., sumps and sewage lagoons) on the NTS provide unique habitats for vegetation and wildlife. In prior years, natural wetlands on the NTS were evaluated for their potential to qualify as "jurisdictional wetlands" under the Clean Water Act (CWA). The presence of three wetland field indicators (vegetation, hydrology, and 
soils) were the basis for determining whether individual wetlands might be considered jurisdictional wetlands (i.e., wetlands over which the U.S. Army Corps of Engineers [USACE] takes legal jurisdiction for the purposes of permitting, mitigation, and rehabilitation for site alterations).

Inherent in the concept of jurisdictional wetlands was the assumption that these isolated wetlands were important for interstate commerce such as hunting, recreation or for other related uses as defined by the CWA. Constructed sumps and sewage lagoons were specifically exempted from jurisdiction by the CWA. In FY 2001 there was a basic shift in interpretation of the laws and policies determining jurisdiction over such natural wetlands. The catalyst for this change in interpretation was the Supreme Court ruling concerning jurisdiction over isolated waters of the U.S. as authorized by the CWA (Solid Waste Agency of Northern Cook County vs. U.S. Army Corps of Engineers (USACE), No. 99-1178, January 9, 2001 ["SWANCC"]). The essence of this ruling was that isolated wetlands (i.e., wetlands not contiguous with adjacent rivers or water systems used for interstate commerce) that were not used for recreation (e.g., hunting or bird watching) and were not located on American Indian lands were no longer considered to be under the control of the USACE, thus eliminating the need for more stringent permitting (Section 404 Permit) prior to proposed habitat alterations and subsequent habitat rehabilitation after alterations.

In 2005 a formal request was initiated by BN through NNSA/NSO to the USACE to confirm that there are no jurisdictional wetlands on the NTS under the current interpretation of the SWANCC ruling. While the SWANCC ruling will most likely alter the potential of NTS wetlands from being considered jurisdictional, the ruling will not alter the basic underlying principle of protecting wetlands as unique and important habitats for wildlife. Characterization of these important mesic habitats and periodic monitoring of their hydrologic and biotic parameters were started in FY 1997 as components of EMAC and will continue in the future. This monitoring will help identify annual fluctuations and range s in measured parameters to help determine if these fluctuations and ranges are natural or are related to NNSA/NSO activities.

\subsubsection{Constructed Wetlands Monitoring}

During FY/CY 2004 descriptive data for human-made wetlands located on Frenchman Lake, including many digital photographs, were collected and entered into the EGIS. It is anticipated that an updated technical supplement report will be prepared during 2006 to describe these and other wetlands that were not included in the initial Nevada Test Site Wetlands Assessment (Hansen et al., 1997). No additional monitoring was done on constructed wetlands nor the technical supplement in 2005 because monitoring efforts were directed to assessing the impacts of numerous wildland fires that occurred during the spring of the year, a time optimally suited for monitoring wetlands.

\subsubsection{Natural Wetlands Monitoring}

Monitoring of numerous wetlands continued this fiscal year to characterize seasonal baselines and trends in physical and biological parameters. Twelve wetlands were visited at least once during the year to record the presence/absence of land disturbance, water flow rates, and surface area of standing water (Table 5-14). Sizes of wetlands monitored varied greatly from very small areas $\left(<1 \mathrm{~m}^{2}\right)$ to moderately sized springs and playa ponds $\left(>23,000 \mathrm{~m}^{2}\right)$. Surface flow rates were low $(<4$ liters $/ \mathrm{min})$ at most wetlands where flow was measurable.

Wildlife use data collected at all water sources are summarized in Table 5-15. Overall, more than 25 species of birds and more than 1090 individual birds were detected during 2005. It was common to observe large numbers of young of the year, Gambel's Quail, and Mourning Doves, throughout the NTS 
(Figure 5-22) and at springs which accounted for the large numbers observed. However, lower number of species counted this year is a function of effort, since only 11 sites were observed compared to 30 last year. Some improvements were conducted at springs this year to benefit wildlife. Reitmann Seep periodically fills in with sediment; it was dug out to make water more available to wildlife. In addition a small guzzler at Tub Spring was installed to hold more water (an improvement over a wet patch of soil). We also focused effort this year at several springs with new camera photographic techniques to photograph animals at night and to identify rarely observed species such as mountain lion, bobcats, ringtail cat, grey fox, etc. (see Section 5.4).

\subsubsection{Constructed Water Source Monitoring}

$\mathrm{BN}$ biologists conducted quarterly monitoring of constructed water sources. These sources, located throughout the NTS (Figure 5-22), include 39 plastic-lined sumps, three earthen ponds, Well 3 Area 6, LANL Pond Area 6, Well 5b, and two radioactive containment ponds visited in December. Several ponds or sumps are located next to each other at the same project site. Many animals rely on these human-made structures as sources of free water. Wildlife and migratory birds may drown in steep-sided or plasticlined sumps (Figure 5-23) as a result of entrapment, or ingest contaminants in drill-fluid sumps or evaporative ponds. Ponds are monitored to assess their use by wildlife and to develop and implement mitigation measures to prevent them from causing significant harm to wildlife. 


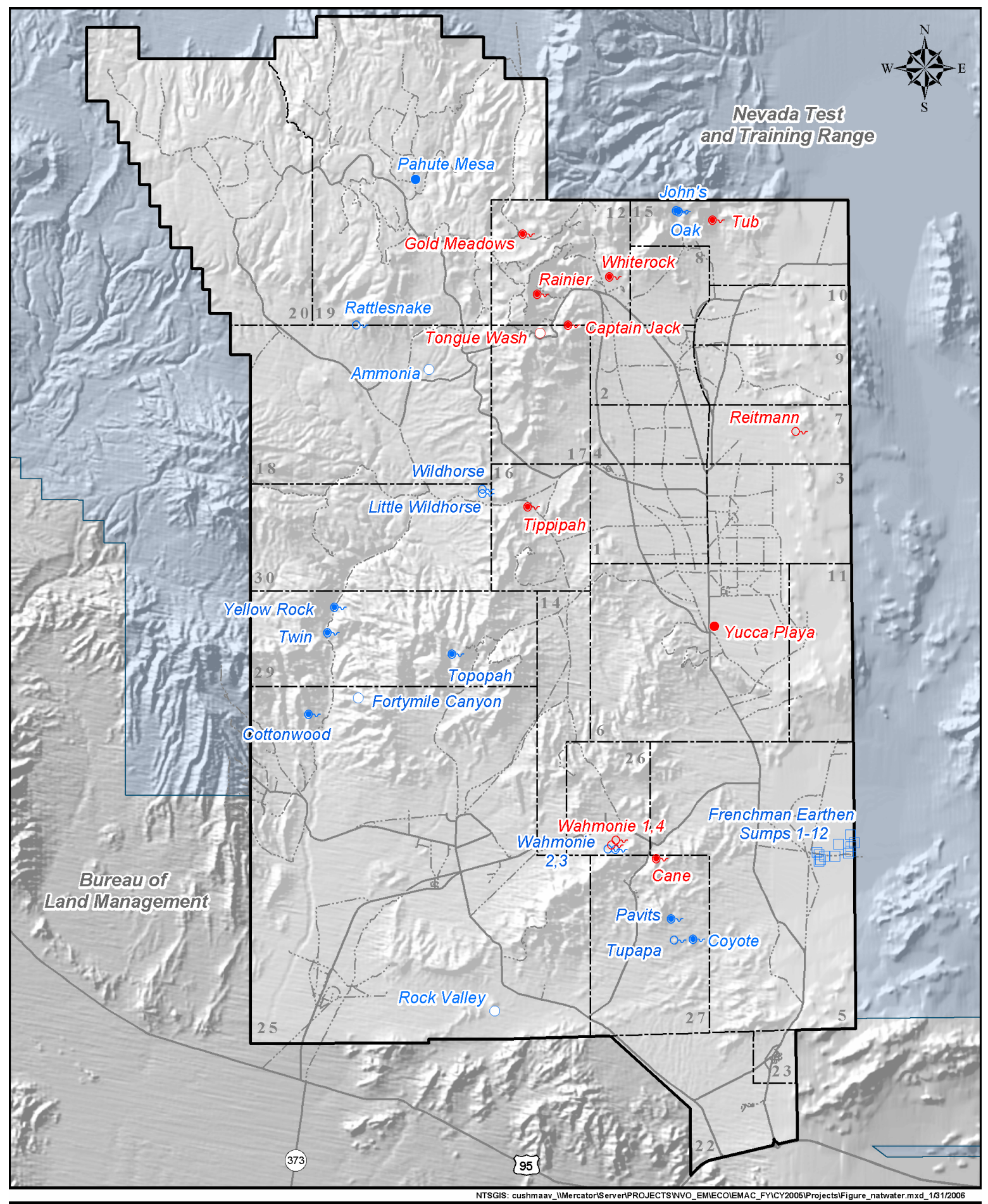

Natural Water Source Types

$\begin{array}{lll}\square & \text { Earthen Sump } & \text { or Seep } \\ \text { - Pond } & \text { or Spring }\end{array}$

( RED indicates wetlands that were sampled.)

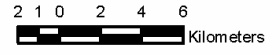
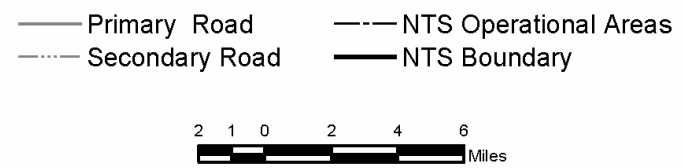

Figure 5-22. Natural water sources on the NTS sampled during 2005. 


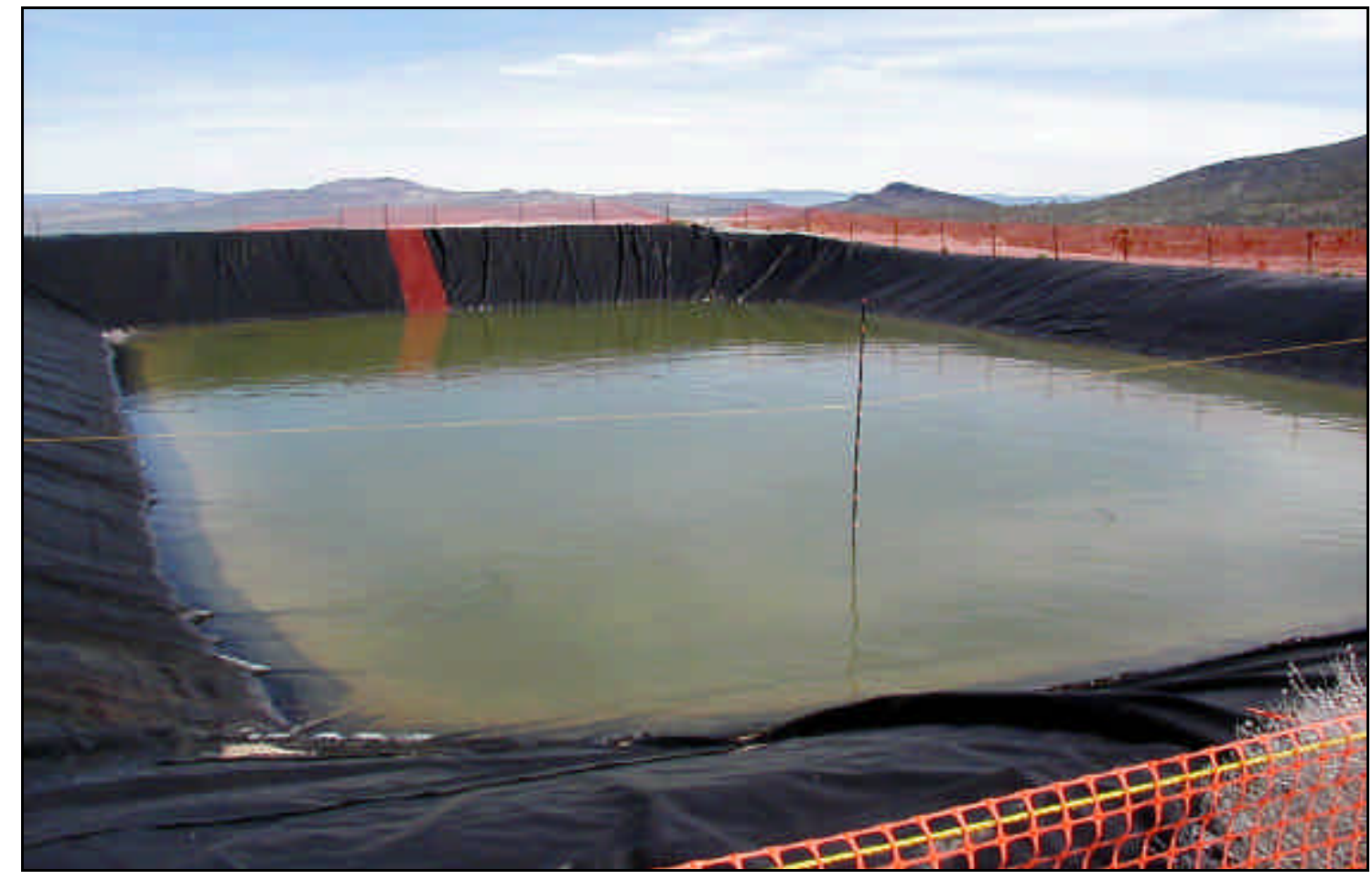

Figure 5-23. Plastic-lined Sump ER-6-2 monitored for wildlife mortality during 2005. (Photo taken by Paul Greger on December 27, 2004). 
Table 5-14. Hydrology data from natural water sources on the NTS collected during 2005.

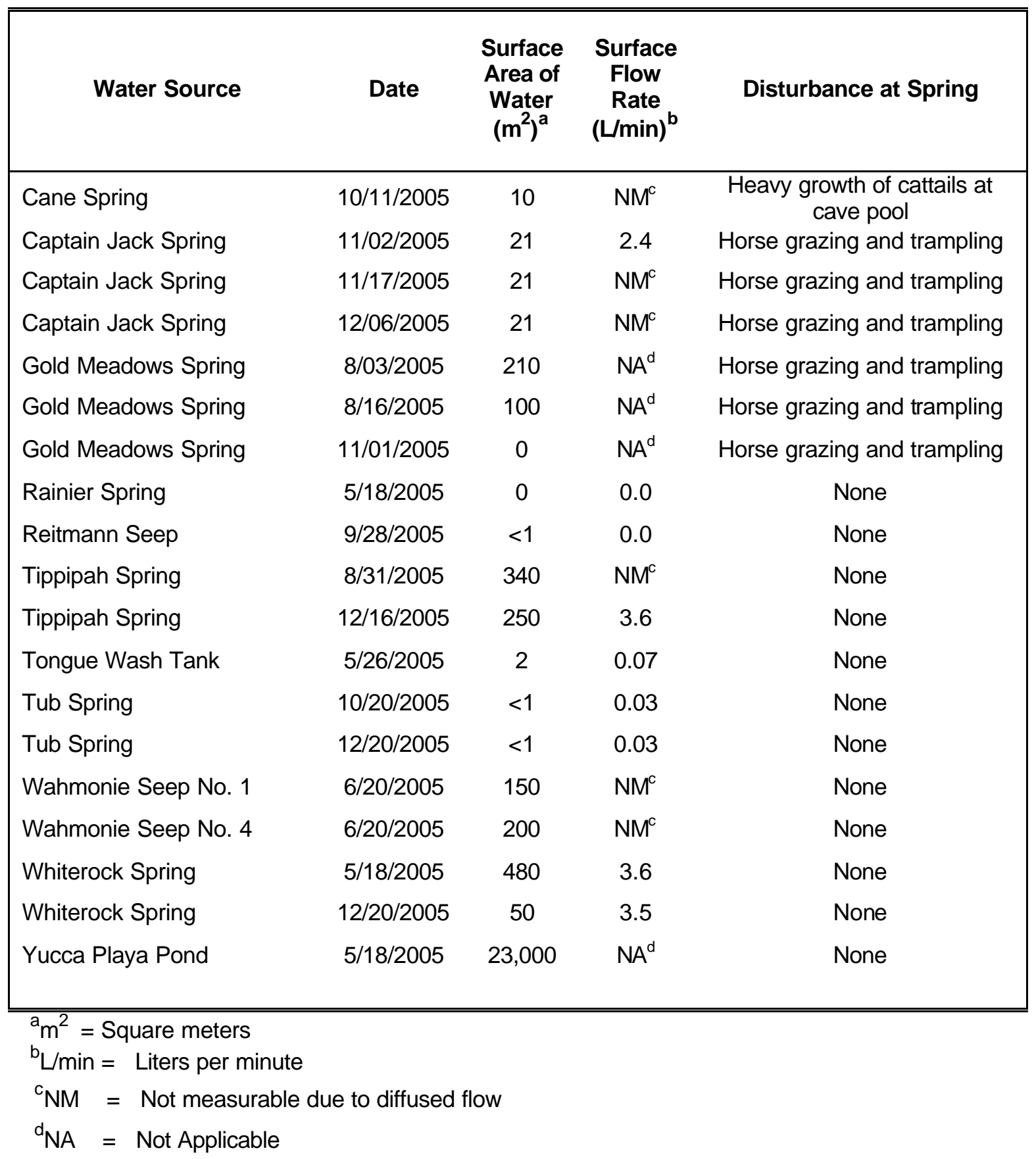


Table 5-15. Number of wildlife observed or inferred at NTS natural water sources during 2005.

\begin{tabular}{|c|c|c|c|c|c|c|c|c|c|c|c|c|c|c|c|c|c|c|c|c|}
\hline Wildiffe Specles Observed & $\begin{array}{l}\frac{g}{\frac{2}{5}} \\
\text { के } \\
\text { है } \\
\text { है }\end{array}$ & 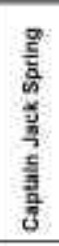 & 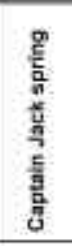 & 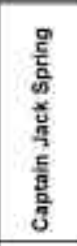 & 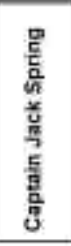 & 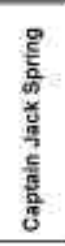 & 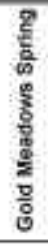 & 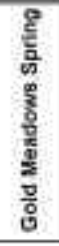 & 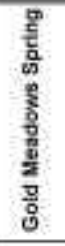 & 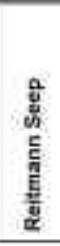 & 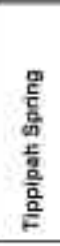 & 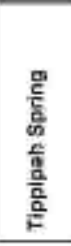 & 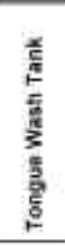 & 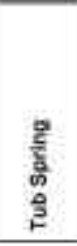 & 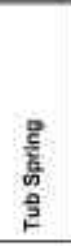 & 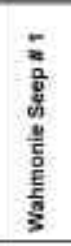 & 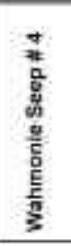 & 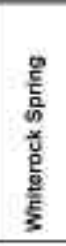 & 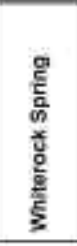 & 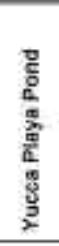 \\
\hline Date Observed (montivday): & 10it1 & 1042 & $11 / 2$ & $11 / 17$ & $11 / 30$ & $12 / 8$ & $8 / 3$ & 8/18 & $11 / 1$ & $9 / 28$ & a/31 & $12 / 16$ & $5 / 28$ & $10 / 20$ & $12: 20$ & 8120 & 0/20 & $5 / 18$ & 12120 & $5 / 10$ \\
\hline \multicolumn{21}{|l|}{ Mamnals } \\
\hline Cojoten (Cenus satrena) & 1 & & & & & & & & $P$ & $\mathrm{P}$ & P & $P$ & $\mathrm{P}$ & $P$ & $p$ & $p$ & $P$ & P & $\mathrm{P}$ & $P$ \\
\hline Costontail rabbit (Syminguis audubamit) & 1 & & & & & & & & & & 1 & & & & & 1. & 1 & & & \\
\hline Feral harse (Equis catollus) & & P & $p$ & P & 10 & p & $P$ & 14 & $P$ & & & & & & & & & & & \\
\hline Mule deer \{Odocoilous heonianus? & p & 1 & 2 & & & & P. & & $\bar{F}$ & $\mathrm{p}$ & $p$ & $p$ & & $\mathrm{P}$ & 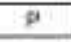 & $p$ & & $p$ & $p$ & $P$ \\
\hline \multicolumn{21}{|l|}{ Birds } \\
\hline American avoces (Rocuivifositra americana) & & & & & & & & & & & & & & & & & & & & 1 \\
\hline Btack-throated sparrow (Amphispiza biuneata) & & & & & & & & & & & & & & & & & $>5$ & & & \\
\hline Breswer's spanow (Spizolia brewwer) & & & & & & & 25 & & & & 25 & & & & & & & & & \\
\hline Browa-headed cowbirs (Molothins afer) & & & & & & & $>5$ & & & & & & & & & & & 6 & & \\
\hline Bushatt (Prantrparuar minimus) & & 20 & $=20$ & 220 & & & & & & & & & & & & & & & & \\
\hline Canyon wren (Catherpes mexicanus) & & & & & & 2 & & & & & & & & & & & & & & \\
\hline Chipping sperrow (Spaizale passerina) & & & & & & & 15 & & & & & & & & & & & & & \\
\hline Chuk:= (Ajectaris chukar) & & 12 & & & & & & & & & & & 10 & 1 & & & 25 & & & \\
\hline Cinnamon teal (Anas cysocptera) & & & & & & & & To & & & & & & & & & & & & \\
\hline Comrnon raven (Carvus corar) & & & & & & & 1 & & & & 2 & 1 & 3 & & & & & & & \\
\hline Coopers haw (Actiallec coopen) & & 1 & 1 & & & & & & & & & & & & & & & 1 & & \\
\hline Gambets quail (Calloepta gambeo) & 40 & & & & & & & & & & 225 & & & & & & $=200$ & & & \\
\hline Golden eagie (Aquña ctrysastox) & & & & & & 1 & & & & & 1 & & & & & & & & & \\
\hline Horved lark (Eramophita Alpestria) & & & & & & & & & & & & 20 & & & & & & & 530 & \\
\hline House finch (Carpodacus mevicana) & 5 & & & & & & 20 & & & & & & & & 10 & & & a & & \\
\hline Loggenead snnke (Lannus tudowlianus) & & & & & & & & & & & & & & & & & 2 & & & \\
\hline Marsh Hawk (Circus cyaneus) & & & 1 & & & 1 & & & & & & & & & 1 & & & & 1 & \\
\hline Mouming dove (Zenaida macroura) & & & & & & & & & & 2 & $>5$ & & 3 & & & $\$ 200$ & $>15$ & $>200$ & & $>100$ \\
\hline Nertharn flicke (Colaptes auratiss) & & 1 & & & & 1 & 1 & & & & & & & & & & & & & \\
\hline Pinion jay (Gymnartinus cyanocephatis) & & & 35 & & & & & & & & & & & & & & & & & \\
\hline Red-1pied hank (Buteo jamsicensa) & 2 & 1 & 1 & & & & & & & & & & & & 1 & & & & & \\
\hline Say's phoebe (Saya sayomis) & & & & & & & & & & 1 & 1 & & & & & & & & & \\
\hline Scrub jay (Apheficcoma coenviescens) & & & 1 & & & & & & & & & & 2 & & & & & & & \\
\hline Snowy ograts iEgrotta thuida) & & & & & & & & & & & & & & & & & & & & 2 \\
\hline Short-eared owl (Asio fenmeus) & & & & & & & & & & & & & & & & & & & 1 & \\
\hline Numbers of bird species detected: & 3 & 5. & 6 & 1 & 0 & 4 & 5 & 1 & 0 & 2 & 6 & 2 & 4 & 1 & 3 & 1 & 5 & 4 & 3 & 2 \\
\hline
\end{tabular}

$P=$ Species presence inferted from sign 
Constructed water sources (Figure 5-24) were visited during four quarterly sampling periods: March, June, September and December 2005. At each site, a BN biologist recorded the presence or absence of standing water and the presence of animals or their sign around the water source. The presence of dirt ramps or plastic ladders, which allow animals to escape if they fall in, have also been installed at many plastic-lined sumps, and the presence, absence, and condition of these structures were also noted. All dead animals (or any remains of an animal) in or adjacent to a human-made water source are recorded.

During 2005, use of plastic-lined sumps was limited to doves, and passerine birds, shorebirds and ducks (e.g., Common ravens, Horned larks, House finches, Spotted sandpipers, and Cinnamon teal). Mourning doves were particularly high in number at many water sources during spring-summer. There were no reports of dove mortalities at any earthen ponds in 2005. No dead animals were detected at any plasticlined sumps during 2005. It is recommended that sediment ramps be constructed in every deep sump on the northern NTS where deer abundance is highest. There are presently 10 deep sumps in Area 20 that need sediment ramps; they are as follows: ER-20-2, ER-20-5, ER-20-6, and UE20N-PS\#1. Sediment ramps, where installed, have been very effective in allowing animals to exit sumps without becoming entrapped. 


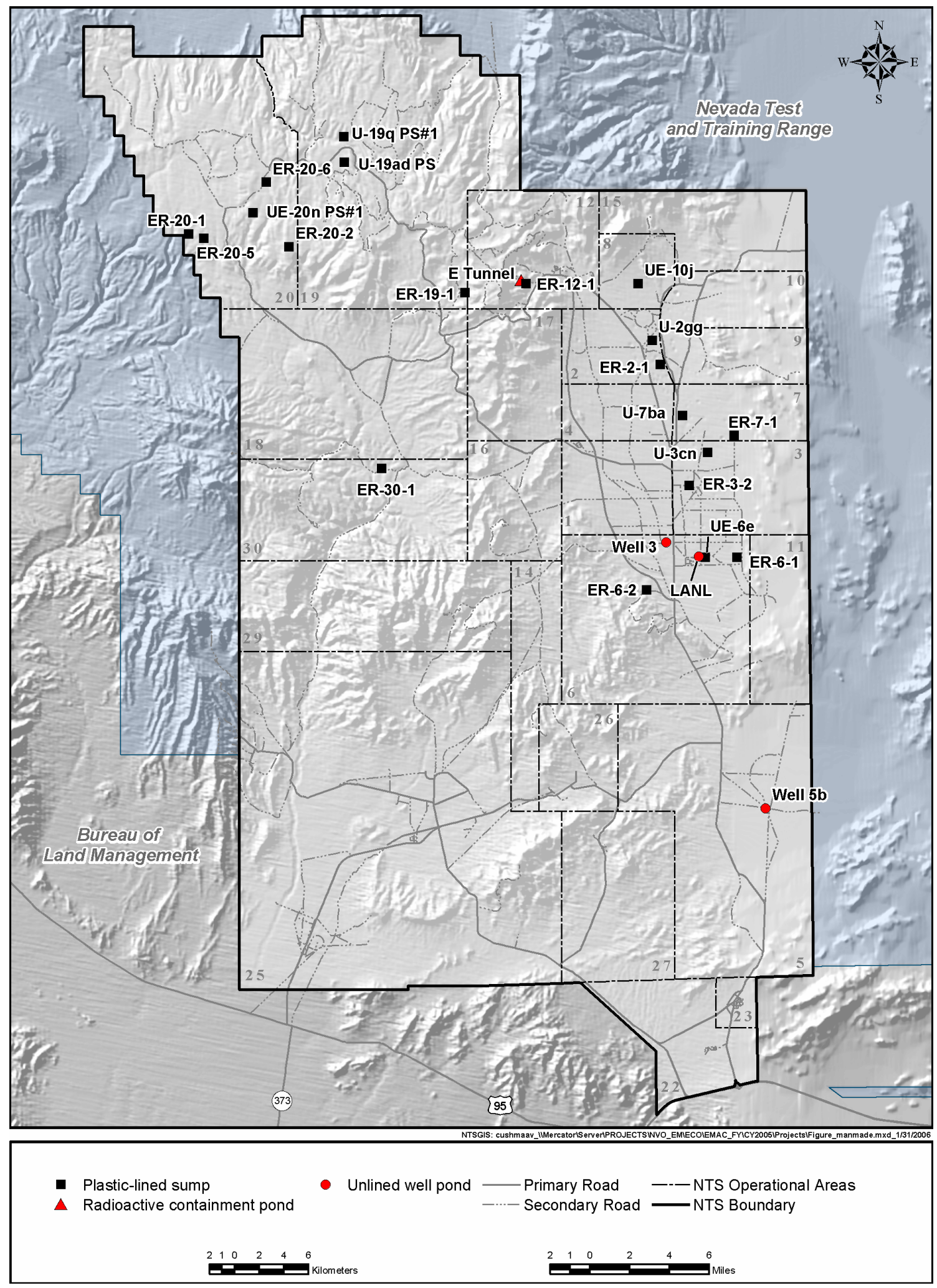

Figure 5-24. Constructed water sources monitored for wildlife use and mortality on the NTS during 2005. 


\subsection{HABITAT RESTORATION MONITORING}

Over the past several decades, some efforts have been made to revegetate disturbed areas on the NTS with native plants (Hunter et al., 1980; 1987; Romney et al., 1989; Wallace and Romney, 1977; 1980; Wallace et al., 1977; 1980). These efforts have been driven by the need to develop viable reclamation techniques in the Mojave Desert which could then be applied to NTS project sites where soil stabilization or habitat reclamation is needed. NNSA/NSO evaluates revegetation as a potential mitigation measure for disturbance to soils on a site-specific basis based on site size, future use, nature of soils, annual precipitation, slope, aspect, and site location (DOE/NV, 1996). To date, the majority of projects for which revegetation has been pursued and funded are abandoned industrial or nuclear test support sites that have been characterized and remediated under the Environmental Restoration (ER) Program. Also, the ER Program has used vegetation closure covers to protect against soil erosion and water percolation into buried waste. In the fall of 2002 a burned area resulting from a wildland fire in Area 12 was revegetated as a measure to reduce the potential for soil erosion following the fire.

A goal of EMAC is to monitor the long-term outcome of both natural vegetation succession and succession by revegetation at disturbed sites throughout the NTS. As opportunities arise, periodic monitoring is conducted to help develop a site-wide habitat restoration plan and better evaluate criteria which influence revegetation success. This year a wildland fire burn site and the revegetation of a closure cover at Area 3 Waste Management Site were monitored.

\subsection{Egg Point Fire Burn Site}

A wildfire of unknown origin burned approximately 121 ha (300 ac) in Area 12 on August 16, 2002. The majority of the plant cover was lost to the fire, named Egg Point, however there were no significant impacts to wildlife or to any sensitive plant or animal species. In the fall of 2002 and spring of 2003, BN Ecological Services completed the revegetation and soil stabilization of the Egg Point fire site. The area was seeded with a mix of native plant species in the fall of 2002 and the following spring approximately 5,000 transplants of plants native to the site were planted in high priority areas

Vegetation monitoring of the burn site has been conducted annually since 2003 to assess the recovery of the vegetation from the effects of the fire and to evaluate the revegetation techniques used in restoration efforts. Monitoring initially focused on seed germination and more recently on plant establishment. Data is collected annually to document the species of plants that are colonizing the site, the density of each species and the contribution of each species to overall plant cover. Data is also collected to document the invasion of non-native annual species.

\subsubsection{Methods}

The area affected by the Egg Point fire is a mosaic of different vegetation and soil types. Most of the area burned was either blackbrush or pinyon/black sagebrush vegetation types. Rocky shallow soils are typical of the upper slopes of the burned area, while deeper soils characterize the lower slopes and bottom areas. Seed mixes were designed for both the upper slopes and lower slopes.

Permanent belt transects, each fifty meters long and one meter wide, are sampled annually to assess vegetative cover and plant density. The transects are nested within the different vegetation and soil types. Typically a minimum of three transects are located within each of the different soil-vegetation combinations. A total of 53 transects are located throughout the site. All or a subset of the transects, are sampled each year depending on time and funding. 
A couple different reclamation techniques were used during the reseeding of the Egg Point fire. Harrowing methods, where seed was either covered using drag chains or raked in by hand, are occasionally evaluated. Also one area was not seeded and is frequently sampled to determine the effect of seeding. In 2004 sampling was conducted to evaluate the method of covering the seed. In 2005 the nonseeded area was sampled for comparison to adjacent seeded areas.

\subsubsection{Monitoring Results}

The increased precipitation received the last two years has had a positive effect on plant density and cover on the Egg Point fire burn site. Plant densities increased most significantly from 2003 to 2004 with another increase although not quite as dramatic from 2004 to 2005. The abundant spring rains created a bloom of annual forbs throughout the region and the burn site was no exception. There were slight increases in the number of perennial shrubs and grasses present and the number of forbs almost doubled from 2004 to 2005 . Overall perennial plant density has increased from just less than one plant $/ \mathrm{m}^{2}$ in 2003 to about two plants $/ \mathrm{m}^{2}$ in 2005 (Table 6-1).

There were minor increases in perennial shrubs with the most notable being Chrysothamnus viscidiflorus (Douglas rabbitbrush) and Ericameria nauseosa (Rubber rabbitbrush). The latter species had declined sharply from 2003 to 2004. Declines in density were noted for Artemisia nova (black sagebrush) and Coleogyne ramosissima (blackbrush). A. nova showed the greatest decline. It was not present in 2003, increased to 0.22 plants $/ \mathrm{m}^{2}$ in 2004 and then dropped to 0.07 plants $/ \mathrm{m}^{2}$ in 2005 (Table 6-1). Overall the density of shrubs and grasses decreased from 2004 to 2005 . The density of forbs increased from 0.5 to 0.8 plants $/ \mathrm{m}^{2}$ from 2004 to 2005 on the restoration site (Figure 6-1).

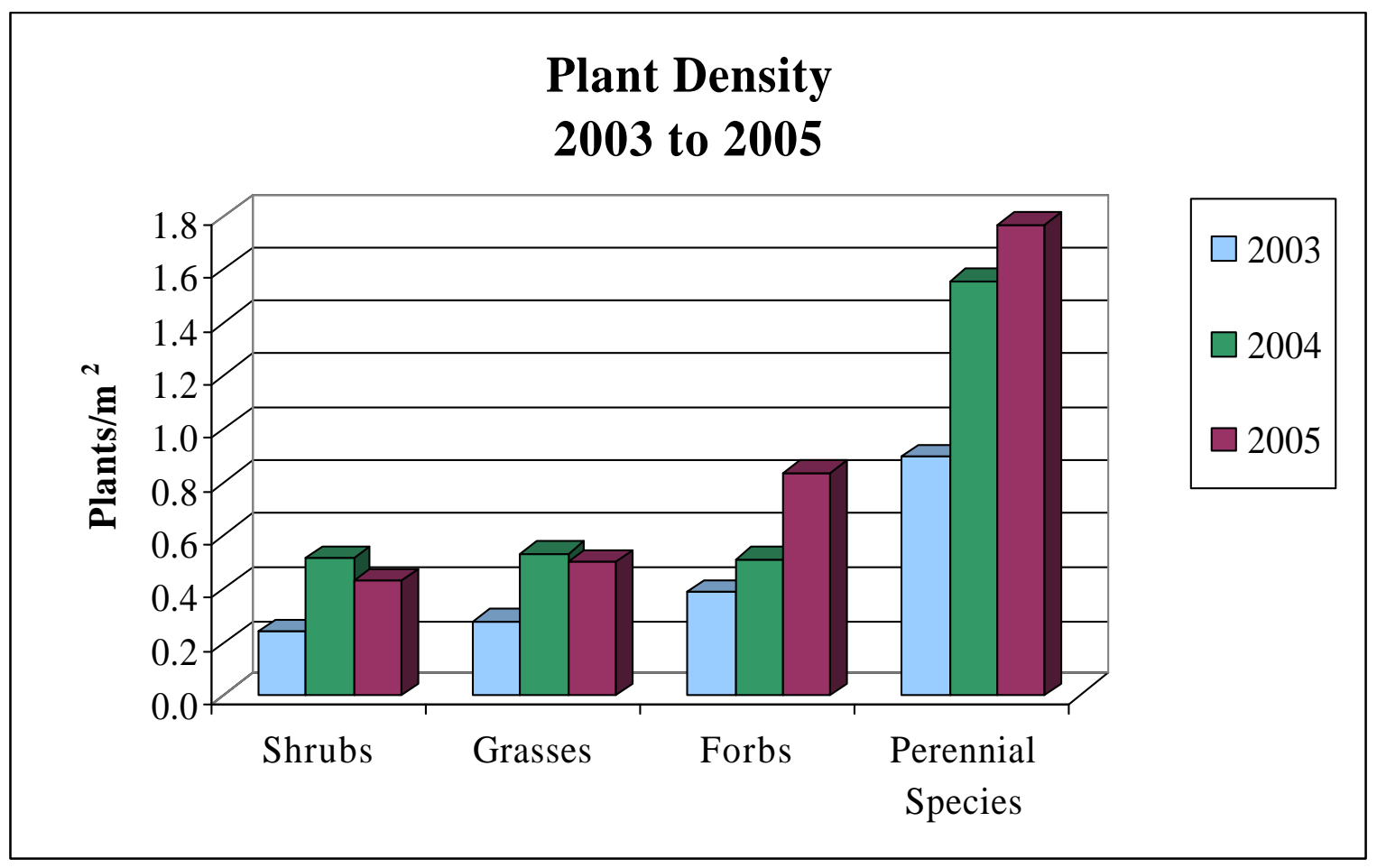

Figure 6-1. Density of plants by life form on the Egg Point fire restoration site from 2003 to 2005. 
Table 6-1. Perennial plant densities on the Egg Point Fire restoration site.

\begin{tabular}{|c|c|c|c|c|}
\hline \multirow[b]{2}{*}{ Species } & \multirow[b]{2}{*}{ Common Name } & \multicolumn{3}{|c|}{ Density (plants/m²) } \\
\hline & & 2003 & 2004 & 2005 \\
\hline \multicolumn{5}{|l|}{ Shrubs } \\
\hline Artemisianova & Black sagebrush & 0 & 0.22 & 0.07 \\
\hline Atriplex canescens & Fourwing saltbush & 0.02 & 0.02 & 0.04 \\
\hline Chrysothamnus viscidiflorus & Douglas' rabbitbrush & 0 & 0.03 & 0.05 \\
\hline Coleogyne ramosissima & Blackbrush & 0.02 & 0.12 & 0.10 \\
\hline Ephedra viridis & Green ephedra & 0 & 0 & 0.01 \\
\hline Ericameria nauseosa & Rubber rabbitbrush & 0.2 & 0.11 & 0.13 \\
\hline Purshia stansburyiana & Stansbury's cliffrose & $\underline{0}$ & $\underline{0.01}$ & $\underline{0.04}$ \\
\hline Total Shrubs & & 0.24 & 0.51 & 0.37 \\
\hline \multicolumn{5}{|l|}{ Grasses } \\
\hline Achnatherum hymenoides & Indian ricegrass & 0.01 & 0.05 & 0.06 \\
\hline Elymus elymoides & Squirreltail & 0.05 & 0.03 & 0.05 \\
\hline Poa secunda & Sandberg's bluegrass & 0.20 & 0.34 & 0.36 \\
\hline Pleuraphis jamesii & Galleta & $\underline{0}$ & $\underline{0.12}$ & $\underline{0.02}$ \\
\hline Total Grasses & & 0.26 & 0.54 & 0.49 \\
\hline \multicolumn{5}{|l|}{ Forbs } \\
\hline Linum lewisii & Lewis flax & 0.11 & 0.26 & 0.29 \\
\hline Eschscholzia californica & California golden poppy & 0.23 & 0 & 0.01 \\
\hline $\begin{array}{l}\text { Heliomeris multiflora var. } \\
\text { nevadensis }\end{array}$ & Nevada goldeneyes & 0.03 & 0.02 & 0.31 \\
\hline Penstemon eatonii & Eaton's penstemon & 0 & 0.13 & 0.11 \\
\hline Penstemon palmeri & Palmer's penstemon & 0 & 0.01 & 0.04 \\
\hline Sphaeralcea grossulariifolia ${ }^{a}$ & Gooseberryleaf globemallow & $\underline{0}$ & $\underline{0.08}$ & $\underline{0.08}$ \\
\hline Total Forbs & & 0.35 & $\mathbf{0 . 5 0}$ & 0.84 \\
\hline Total Perennial Species & & 0.90 & 1.55 & 1.77 \\
\hline
\end{tabular}

${ }^{\mathrm{a}}$ Not included in seed mixes 
The density of grasses doubled from 2003 to 2004 but was about that same in 2005 as it was in 2004 (Figure 6-1) except for Pleuraphis jamesii (galleta) which declined from 0.12 plants $/ \mathrm{m}^{2}$ in 2004 to 0.02 plants $/ \mathrm{m}^{2}$ this year (Table 6-1). All other species experienced a slight increase over 2004 densities.

The only major difference in the density of forbs this year over 2004 was a 15 -fold increase of Heliomeris multiflora var. nevadensis (Nevada golden eyes). The density of all other species was about the same as in 2004.

Plant cover was estimated on 16 of the 53 sites this year. Overall plant cover was 31.2 percent in 2005. About 23 percent of the total cover was from perennial shrubs and grasses, 40 percent was from noninvasive forbs and the remaining 37 percent was from invasive annual plants. Non vegetative cover included 13.7 percent litter, 14.9 percent bare ground and the remaining 39.4 percent was rock.

\subsubsection{Upper Slopes}

The density of perennial plant species on the upper slopes of the Egg Point fire restoration site more than doubled from 2003 to 2004 but is about the same in 2005 as it was in 2004 (Table 6-2). There was about a 30 percent decrease in the number of shrubs present on the site. There were fewer A. nova and $C$. ramosissisma plants than in previous years but very little change in the density of other shrubby species (Table 6-2).

The density of grass species on the upper slopes was essentially the same as it was last year. There were slight increases in Achnatherum hymenoides (Indian ricegrass), Elymus elymoides (squirreltail), and Poa secunda (Sandburg's bluegrass) and a decrease in P. jamesii from 0.18 to 0.03 plants $/ \mathrm{m}^{2}$.

Forbs make up about 40 percent of the total plant density this year compared to about 30 percent last year. There was a slight decrease in Linum lewisii (Lewis flax)and Penstemon eatonii (Eaton's penstemon) and an eight-fold increase in the number of $\mathrm{H}$. multiflora var. nevadensis plants. Overall there was a 30 percent increase in the number of perennial forbs from 2004 to 2005.

Seeded versus Non-Seeded-Of a major concern during any reseeding project is the effectiveness of the effort to reseed an area, especially on the steep rocky terrain characteristic of the Egg Point fire restoration site. An area on the upper rocky slopes of the site was seeded and the seed was raked into the soil. An area adjacent to this site was not seeded. These sites were sampled in 2005. The results of the sampling show that seeding was beneficial. The density of perennial plants on the non-seeded area was less than one-tenth of the density on the seeded area (Figure 6-2).

There were a few shrubs $\left(0.22\right.$ plants $\left./ \mathrm{m}^{2}\right)$, hardly any grasses $\left(0.02\right.$ plants $\left./ \mathrm{m}^{2}\right)$ and no forbs. Density information on annual plants was not recorded this year but will be in future years to determine if these unseeded sites are more susceptible to invasive annuals.

\subsubsection{Lower Slopes}

Plant density on the lower slopes of the Egg Point fire restoration site increased from 0.57 plants $/ \mathrm{m}^{2}$ in 2004 to 1.43 plants $/ \mathrm{m}^{2}$ in 2005 (Table 6-2). Species showing the greatest increase was E. nauseosa, a common shrub on the site, E. elymoides, one of three common native grasses, and L. lewisii and $H$. multiflora var. nevadensis. The latter two species are perennial forbs native to the area and responded favorably to the abundant precipitation the past two years. L. lewisii was included in the seed mix used to seed the lower slopes of the restoration site. Overall there was an increase in the number of shrubs on the 
lower slopes from $0.26 \mathrm{shrubs} / \mathrm{m}^{2}$ in 2004 to $0.43 \mathrm{shrubs} / \mathrm{m}^{2}$ in 2005 . Grasses increased from 0.08 to 0.12 plants $/ \mathrm{m}^{2}$. There were almost four times as many forbs in 2005 as there were in 2004 (Table 6-2).

Table 6-2. Perennial plant densities on the upper and lower slopes of the Egg Point Fire restoration site.

\begin{tabular}{|c|c|c|c|c|c|c|c|}
\hline \multicolumn{2}{|c|}{ Seeded Species } & \multicolumn{3}{|c|}{$\begin{array}{c}\text { Upper Slopes } \\
\text { Density (plants/m²) }\end{array}$} & \multicolumn{3}{|c|}{$\begin{array}{c}\text { Lower Slopes } \\
\text { Density (plants } / \mathbf{m}^{2} \text { ) }\end{array}$} \\
\hline Scientific Name & Common Name & 2003 & 2004 & 2005 & 2003 & 2004 & 2005 \\
\hline \multicolumn{8}{|l|}{ Shrubs } \\
\hline Artemisia nova & Black sagebrush & 0 & 0.33 & .11 & a & & \\
\hline Atriplex canescens & Fourwing saltbush & a & & & 0.05 & 0.06 & 0.09 \\
\hline Chrysothamnus viscidiflorus & Douglas' rabbitbrush & 0 & 0.04 & .05 & 0 & 0.02 & 0.05 \\
\hline Coleogyne ramosissima & Blackbrush & 0.02 & 0.14 & .09 & 0.02 & 0.08 & 0.11 \\
\hline Ephedra viridis & Green ephedra & 0 & 0 & 0.01 & 0 & 0 & 0 \\
\hline Ericameria nauseosa & Rubber rabbitbrush & 0.08 & 0.11 & 0.11 & 0.42 & 0.09 & 0.16 \\
\hline \multirow[t]{2}{*}{ Purshia stansburyiana } & Stansbury's cliffrose & 0 & 0.01 & .05 & 0 & 0.01 & 0.02 \\
\hline & Total Shrubs & 0.10 & 0.63 & 0.42 & 0.49 & 0.26 & 0.43 \\
\hline \multicolumn{8}{|l|}{ Grasses } \\
\hline Achnatherum hymenoides & Indian ricegrass & 0.01 & 0.04 & 0.06 & 0.02 & 0.06 & 0.04 \\
\hline Elymus elymoides & Squirreltail & 0.05 & 0.03 & 0.06 & 0.06 & 0.01 & 0.04 \\
\hline Poa secunda & Sandberg's bluegrass & 0.27 & 0.50 & 0.58 & 0.07 & 0 & 0.03 \\
\hline \multirow[t]{2}{*}{ Pleuraphis jamesii } & Galleta & $0.01^{\mathrm{a}}$ & 0.18 & 0.03 & 0 & 0.01 & 0.01 \\
\hline & Total Grasses & 0.34 & 0.75 & 0.73 & 0.15 & 0.08 & 0.12 \\
\hline \multicolumn{8}{|l|}{ Forbs } \\
\hline Linum lewisii & Lewis' flax & 0.07 & 0.32 & 0.23 & 0.19 & 0.14 & 0.38 \\
\hline Eschscholzia Californica & California golden poppy & 0.11 & 0 & 0.01 & 0.46 & 0 & 0 \\
\hline $\begin{array}{l}\text { Heliomeris multiflora var. } \\
\text { nevadensis }\end{array}$ & Nevada goldeneyes & 0.03 & 0.03 & 0.29 & 0.04 & 0 & 0.34 \\
\hline Penstemon eatonii & Eaton's penstemon & 0 & 0.19 & 0.16 & 0 & 0.01 & 0.02 \\
\hline Penstemon palmeri & Palmer's penstemon & $\mathrm{a}$ & & 0.02 & 0 & 0.02 & 0.05 \\
\hline \multirow[t]{3}{*}{ Sphaeralcea grossulariifolia ${ }^{a}$} & $\begin{array}{l}\text { Gooseberryleaf } \\
\text { globemallow }\end{array}$ & 0 & 0.09 & 0.09 & 0 & 0.06 & 0.07 \\
\hline & Total Forbs & 0.21 & 0.63 & $\mathbf{0 . 8 0}$ & 0.69 & $\mathbf{0 . 2 3}$ & 0.86 \\
\hline & Total Perennial Species & 0.65 & 2.04 & 1.98 & 1.35 & 0.57 & 1.43 \\
\hline
\end{tabular}

${ }^{\mathrm{a}}$ Not included in seed mixes 


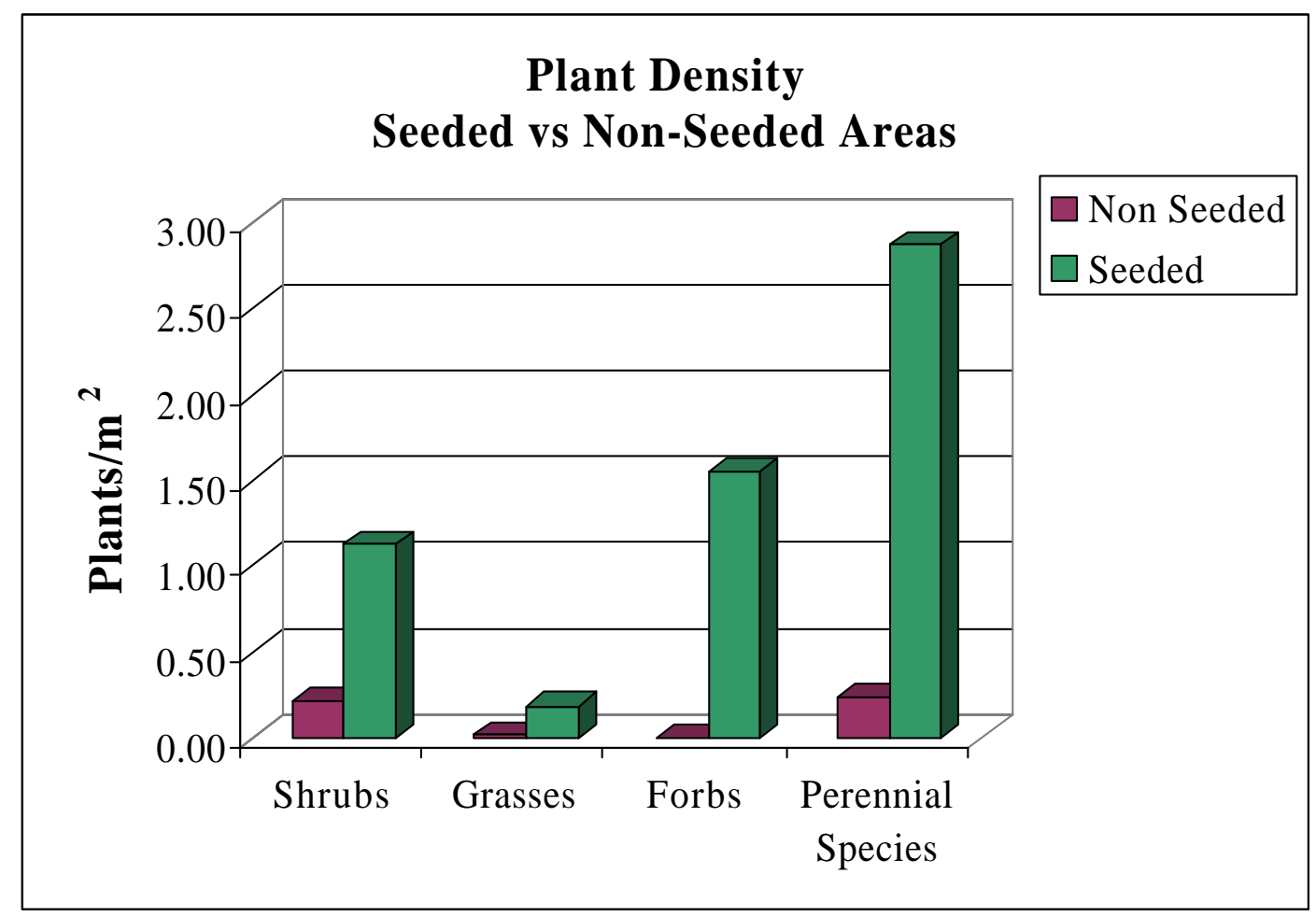

Figure 6-2. Comparison of plant density on seeded and non-seeded sites on the upper slopes of the Egg Point Fire restoration site.

Seeded versus Non-Seeded-An area in the middle basin on the lower slopes of the Egg Point fire restoration site was not seeded. The non-seeded area was sampled this spring and compared to plant densities on adjacent seeded areas. As with the results of the evaluation of the upper slope, plant density was higher on the seeded areas than on the non-seeded area. The density of perennial plants on the nonseeded area was 27 percent of the density on the seeded areas (Figure 6-3). There were 44 percent as many shrubs, 15 percent as many grasses, and about a 22 percent as many forbs as on the seeded sites. As on the upper slopes, density of annual plants was not recorded in 2005 but will be in future years to determine if these unseeded sites are more susceptible to invasive annuals.

\subsection{Habitat Restoration at CAU 110, U-3ax/bl Closure Cover}

A closure cover for the U-3ax/bl disposal unit in Area 3 of the Nevada Test Site was approved and constructed in the fall of 2000. Immediately after the construction of the closure cover the reestablishment of a cover of native vegetation was initiated. The surface was ripped to about $15 \mathrm{~cm}$ (6 inches [in]) to provide a suitable seedbed and the closure cover was seeded with a mix of nine native shrub species, two native grasses and one native forb. The slopes along the periphery of the closure cover and the area between the cover and the fence were not seeded.

To maximize the potential for seed germination and plant establishment, seeding was followed with supplemental irrigation which began the latter part of January 2001 and ended the first week of June 2001. The combination of natural precipitation and supplemental irrigation totaled $21.6 \mathrm{~cm}(8.5 \mathrm{in})$ of equivalent precipitation during this period. Natural precipitation since 2001 in this region for the water year (October 1 to September 30) was $4.1 \mathrm{~cm}(1.6 \mathrm{in})$ in 2002, $12.7 \mathrm{~cm}(5.0 \mathrm{in})$ in 2003, $19.3 \mathrm{~cm}$ (7.6 in) in 2004 and $32.3 \mathrm{~cm}$ (12.7 in) in 2005 . Natural precipitation was above average two of the four years. 
There were abundant spring rains in 2004 but very little precipitation the previous fall. For the 2005 water year about $11.2 \mathrm{~cm}$ (4.4 in) were received from October to December which was followed by $14.0 \mathrm{~cm}(5.5 \mathrm{in})$ during the spring months and $7.1 \mathrm{~cm}(2.8 \mathrm{in})$ during the summer months.

The success of the reseeding effort on the closure cover has been evaluated each year since 2001 .

Vegetation monitoring occurs during the period of peak vegetative production, usually between late April and mid June, and includes estimates of plant density and plant cover on the reseeded closure cover and on unseeded areas peripheral to the closure cover but still inside the fenced area.

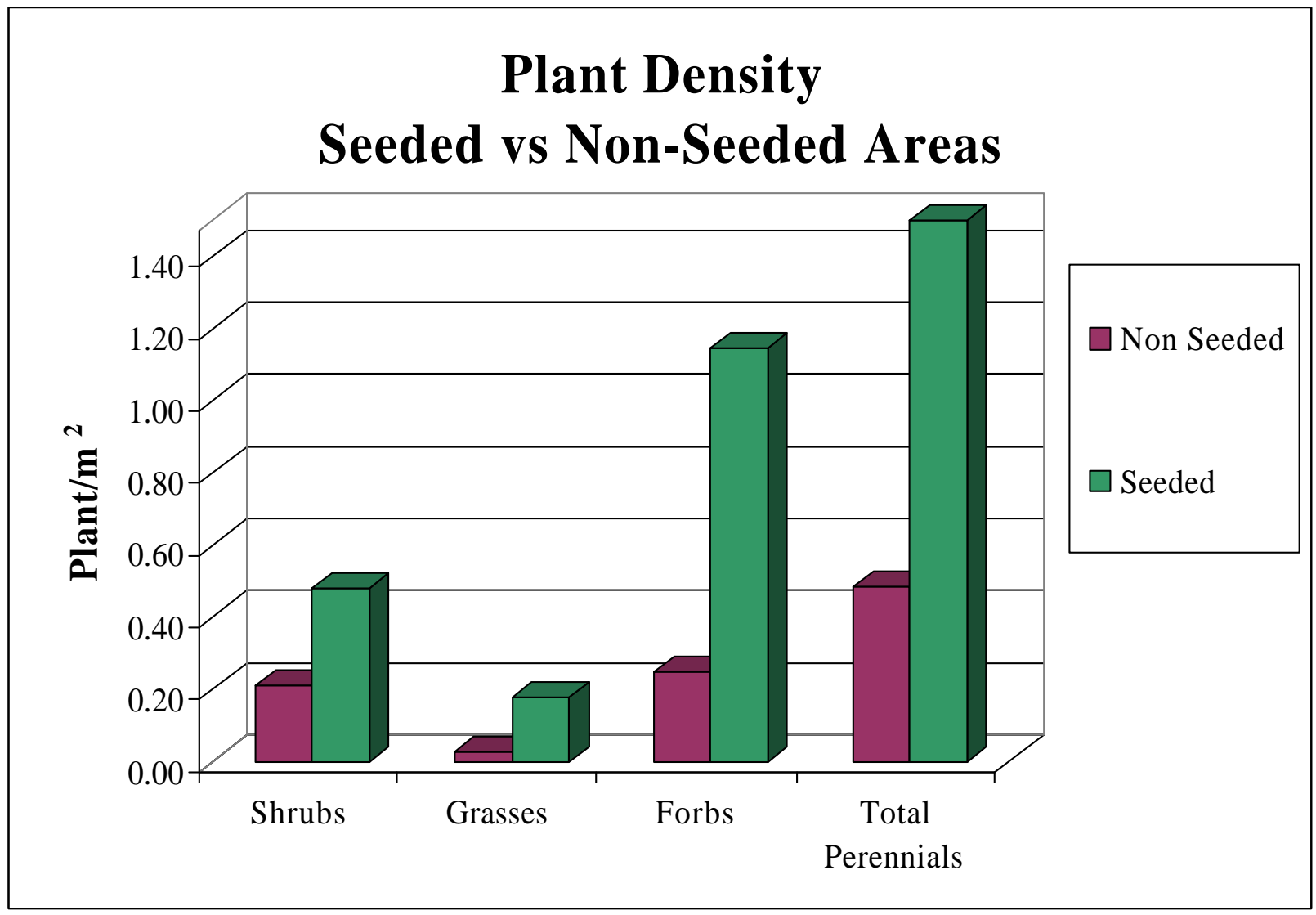

Figure 6-3. Comparison of plant density on seeded and non-seeded sites on the lower slopes of the Egg Point Fire restoration site.

\subsubsection{Methods}

The same vegetation monitoring methods have been used each year since sampling began in 2001 . Twenty one transects are located on the closure cover at 40 meter intervals starting at the western edge and continuing to the eastern end. Transects are oriented in north-south direction. Transects 1 and 21 are not sampled because of their proximity to the edge and susceptibility to disturbance. Five of the 19 transects are randomly selected each year. In 2005 transects 4, 5, 8, 14, and 15 were sampled. In addition, one transect located along the northern edge of the closure cover in an area that was not seeded, was sampled. The ocular projection device is placed at 4-meter intervals along each transect. At each location four ocular points are projected and the type of cover, i.e. rock, bare ground, litter, mulch, or 
plant species, intercepted by the points is recorded. A total of 100 points are sampled per transect for a total of 600 points.

Plant density data are collected each year from meter square quadrats placed along the transects. Quadrats are randomly placed along the transects and the number of individual plants encountered within the quadrat is counted and recorded by species. A minimum of 50 quadrats are sampled each year. In 2005, 53 quadrats were sampled on the closure cover and 10 quadrats in the non-seeded areas along the periphery of the closure cover.

\subsubsection{Vegetation Monitoring Results}

Plant Cover - Perennial plant cover continues to increase on the closure cover. Plant cover was 75 percent higher this year than it was last year (Table 6-3). The amount of cover contributed by Atriplex confertifolia (shadscale) and Ephedra nevadensis (Nevada ephedra), the two most common perennial shrubs on the closure cover, almost doubled from 2004 to 2005. A. confertifolia accounts for over 90 percent of the total perennial plant cover which it has since cover was first estimated in 2003 . In response to above normal precipitation shadscale plants were very robust and produced an abundant crop of seed (Figure 6-4). Although E. nevadensis contributes less to overall perennial plant cover it has increased significantly each year since 2003. There was a doubling of the amount of E. nevadensis cover this year compared to last year. Krascheninnikovia lanata (winterfat), the other major component of perennial plant cover, decreased slightly, but it is still higher than it was two years ago. K. lanata plants showed remarkable growth this year and many plants were in early seed set when sampling was conducted (Figure 6-5).

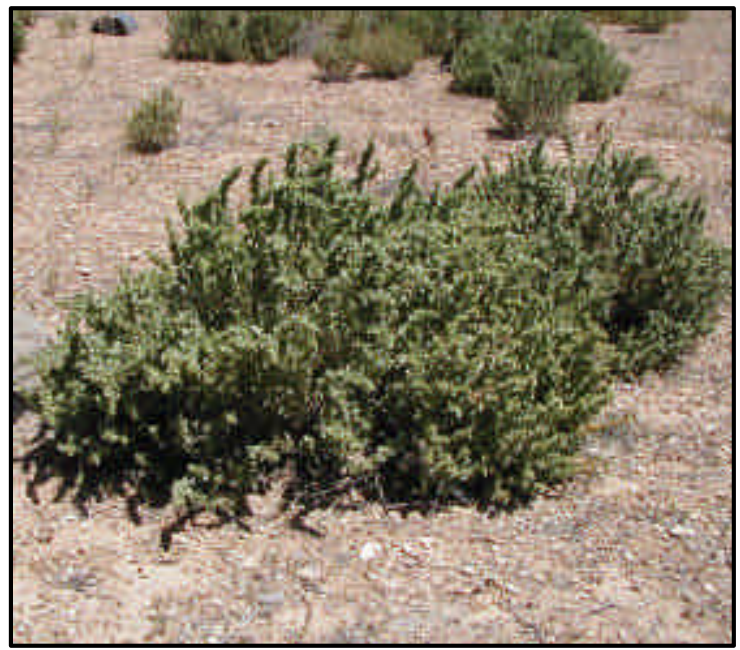

Figure 6-4. A. confertifolia in early seed production on $\mathrm{U}-3 \mathrm{ax} / \mathrm{bl}$ closure cover. Photo by D. Anderson June 2005.

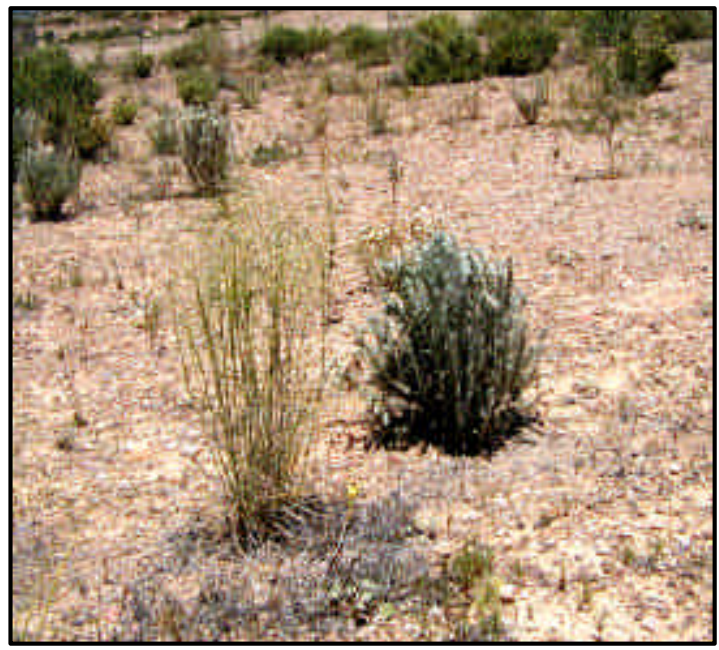

Figure 6-5. K. lanata and A. hymenoides in late flower/early seed production on U-3ax/bl closure cover. Photo by D. Anderson June 2005.

Annual plant cover didn't differ significantly from last year. In 2004 about 25 percent of total plant cover was from annuals (Table 6-3). In 2005, a year of abundant precipitation, annuals only make up 17 percent of the total cover. This is an indication that perennial plants are well established and are outcompeting the annuals for nutrients and moisture. A couple annual buckwheat plants make up a third of the cover, Salsola tragus (prickly Russian thistle) another third and the remaining third is an assortment of common native annual species. At the time of sampling both Halogeton glomerata (halogeton), and $S$. tragus plants were young seedlings and will mature during the summer months. It is noteworthy that 
S. tragus cover decreased from 3 percent to 1.2 percent from 2004 to 2005 and H. glomerata has not contributed to plant cover, yet.

Total plant cover on edges of closure cover, which has re-seeded naturally, was 23 percent, slightly higher than on the closure cover. A major difference is that all of the plant cover on the un-seeded edges, which doesn't appear anything like the plant cover on the closure cover, is from annual plants. Almost 80 percent of the cover was from $S$. tragus and $H$. glomerata, two common invasive weedy species. In comparison, annual plants barely make up 5 percent of the cover on the closure cover.

Table 6-3. Average percent plant canopy cover on U-3ax/bl closure cover from 2001 to 2005.

\begin{tabular}{|c|c|c|c|c|c|c|c|}
\hline Lifeform & Species & 2001 & 2002 & 2003 & 2004 & $\begin{array}{c}2005 \\
\text { Seeded }\end{array}$ & $\begin{array}{c}2005 \\
\text { Unseeded }\end{array}$ \\
\hline \multirow[t]{5}{*}{ Perennials } & Atriplex confertifolia & * & * & 2.2 & 8.6 & 15.4 & 0 \\
\hline & Ephedra nevadensis & * & * & 0 & 0.4 & 0.8 & 0 \\
\hline & Krascheninnikovia lanata & * & * & 0.2 & 0.6 & 0.4 & 0 \\
\hline & Atriplex canescens & * & * & 0 & 0 & 0.2 & 0 \\
\hline & Total Perennial Cover: & 2.6 & 6.4 & 2.4 & 9.6 & 16.8 & 0 \\
\hline \multirow[t]{10}{*}{ Annuals } & Eriogonum & * & * & 0.6 & 0.2 & 1.2 & 4.0 \\
\hline & Halogeton glomerata & * & * & 0 & 0 & 0 & 6.0 \\
\hline & Salsola tragus & * & * & 0 & 3.0 & 1.2 & 12.0 \\
\hline & Other annuals & * & * & 0.2 & 0 & 0.8 & 1.0 \\
\hline & Bromus tectorum & * & * & 0 & 0 & 0.2 & 0 \\
\hline & Total Annual Cover: & 5.2 & 0.0 & 0.8 & 3.2 & 3.4 & 23.0 \\
\hline & Total Plant Cover: & 7.8 & 6.4 & 3.2 & 12.8 & 20.2 & 23.0 \\
\hline & Litter/Mulch: & 43.6 & 24.1 & 28.0 & 14.6 & 26.2 & 11.0 \\
\hline & Bare Ground: & 48.6 & 69.5 & 30.4 & 38.4 & 5.4 & 29.0 \\
\hline & Rock: & $* *$ & $\star *$ & 38.4 & 34.2 & 48.2 & 37.0 \\
\hline
\end{tabular}

\footnotetext{
* Not recorded by species

** Included with bare ground
}

Plant Density - Plant density in 2005 was 5.1 plants $/ \mathrm{m}^{2}$, which represents a slight increase over the last two years (Table 6-4). The density of A. confertifolia and E. nevadensis increased slightly from 2004 to 2005 , while $K$. lanata and $A$. hymenoides decreased slightly. These minor changes in plant density were associated with a 75 percent overall increase in plant cover from 2004 to 2005 (Table 6-3). Plants on the closure cover appear to be well established at this point and major changes as a result of favorable growing conditions, such as experienced this year, would be in the form of increased plant growth as measured by plant cover and not the establishment of new plants as would be indicated by increases in plant density. This appears to be the situation with A. confertifolia, the most abundant species on the 
Table 6-4. Summary of plant density (plants/m2) from 2001 to 2005 on U-3ax/bl closure cover.

\begin{tabular}{|c|c|c|c|c|c|c|c|}
\hline Lifeform & Common Name* & 2001 & 2002 & 2003 & 2004 & 2005 & Unseeded \\
\hline \multirow[t]{11}{*}{ Shrubs } & Picrothamnus desertorum & 1.9 & 0 & 0 & 0 & 0.02 & 0 \\
\hline & Atriplex confertifolia & 13.4 & 10.3 & 2.7 & 2.3 & 2.5 & 0 \\
\hline & Ephedra nevadensis & 6.8 & 6.7 & 1.3 & 1.5 & 1.8 & 0 \\
\hline & Ericameria nauseosa & 11.2 & 0.7 & 0 & 0 & 0 & 0 \\
\hline & Eriogonum fasciculatum & 11.3 & 4.2 & 0 & 0 & 0 & 0 \\
\hline & Grayia spinosa & 1.9 & 0.1 & 0.1 & 0.02 & 0.02 & 0 \\
\hline & Hymenoclea salsola & 9.3 & 0 & 0 & 0 & 0 & 0 \\
\hline & Krascheninnikovia lanata & 0.3 & 2.7 & 0.4 & 0.7 & 0.4 & 0 \\
\hline & Lycium andersonii & 0 & 0 & 0 & 0 & 0 & 0 \\
\hline & Atriplex canescens ${ }^{* *}$ & 0.2 & 0.1 & 0 & 0 & 0 & 0 \\
\hline & Total Shrubs: & 56.3 & 25.8 & 4.5 & 4.5 & 4.7 & 0 \\
\hline \multirow[t]{3}{*}{ Grasses } & Achnatherum hymenoides & 5.8 & 1.3 & 0.3 & 0.4 & 0.3 & 0 \\
\hline & Elymus elymoides & 3.3 & 0.2 & 0 & 0 & 0.1 & 0 \\
\hline & Total Grasses: & 9.1 & 1.5 & 0.3 & 0.4 & 0.4 & 0 \\
\hline \multirow[t]{2}{*}{ Forbs } & Sphaeralcea ambigua & $<0.1$ & 0 & 0 & 0 & 0 & 0 \\
\hline & Total Perennial Density: & 65.4 & 27.3 & 4.8 & 4.9 & 5.1 & 0 \\
\hline \multirow[t]{9}{*}{ Annuals } & Eriogonum spp. & - & - & 15.1 & 7.8 & 13.7 & 37.1 \\
\hline & Halogeton glomerata & - & - & 0.2 & 3.9 & 12.5 & 22.6 \\
\hline & Salsola tragus & - & - & 3.4 & 77.0 & 70.3 & 182.5 \\
\hline & Other annual forbs & - & - & 0.8 & 0.4 & 2.0 & 0.5 \\
\hline & Bromus tectorum/Bromus rubens & - & - & 0.1 & 0.5 & 1.9 & 1.4 \\
\hline & Total Annuals: & - & - & 19.6 & 80.9 & 100.5 & 244.1 \\
\hline & Total Plant Density: & 65.4 & 27.3 & 24.4 & 85.8 & 105.6 & 244.1 \\
\hline & Number of Perennial Species: & 11 & 9 & 5 & 5 & 7 & 0 \\
\hline & Number of Annual Species: & - & - & 6 & 5 & 13 & 7 \\
\hline
\end{tabular}

${ }^{*}$ Nomenclature according to the PLANTS Database (USDA, 2005)

** Not seeded

- no data on annuals taken that year

closure cover, and $K$. lanata and A. hymenoides. Density for these three species has not differed significantly over the last three years (Table 6-3). The density of E. nevadensis has increased by about 15 percent each year for the last three years.

A few seedlings were observed this year which would be expected with the favorable amount of precipitation this year. Of note were seedlings of A. hymenoides and Picrothamnus desertorum (bud sagebrush). The seed for the A. hymenoides seedlings could have come from seed from plants that have 
established on site and set seed last year. However, $P$. desertorum has not been observed on the closure cover since the first year and seed most likely came from residual seed in the soil.

Grayia spinosa (spiny hopsage) has been present on site since 2001. This year like last year only one plant was encountered. Several other individuals of G. spinosa were observed on the closure cover, but they are uncommon. The other species of note is Elymus elymoides (squirreltail). It has not been observed on the closure cover since 2002. A few individuals, mainly seedlings, were observed this year. It will be important that the new plants establish, mature and set seed in order for this species to persist on the closure cover.

In 2005 the density of annual plants was the highest it has ever been. The 100 plants $/ \mathrm{m}^{2}$ this year represents a 20 percent increase over last year and a five-fold increase over annual density estimates in 2003. The species with the most significant increases were buckwheat, H. glomerata and B. tectorum (Table 6-3). Interestingly the density of Russian thistle was slightly lower this year than last year. As was common throughout much of the region this spring there was an abundance of native annual forbs. Common native wildflowers observed on the closure cover this year included Malacothrix glabrata (smooth desertdandelion), Chaenactis spp. (dustymaiden), Mentzelia spp. (blazingstar), Cryptantha nevadensis (Nevada cryptantha), Amsinckia tessellate (bristly fiddleneck) and Sisymbrium altissimum (tall tumblemustard).

Plant Diversity - During the first couple of growing seasons after reseeding there were about 10 different perennial plant species on the site. By the third growing season and the third year of below normal precipitation, $P$. desertorum, E. nauseosa, Eriogonum fasciculatum (yellow buckwheat) and E. elymoides, once present, were absent. The number of individual plants of the other species declined drastically during this period, but the native species were able to persist until more favorable growing conditions occurred in 2004. This year $P$. desertorum and E. elymoides two species not found on the closure cover since 2002, were found on the closure cover (Table 6-3).

The number of annual species more than doubled from 2004 to 2005 (Table 6-3). This increase is a result of sufficient moisture and the migration of seed of both native and non-native annual plants onto the closure cover. With the addition of about a dozen native annual species the closure cover vegetation appears much like native plant communities with a mix of perennial shrubs and grasses, and native annual plants.

\subsubsection{Summary}

Total plant cover increased from 12.8 percent in 2004 to 20.2 percent in 2005 . This is a good indication that native plant species on the closure cover have successfully survived the drought conditions that followed reseeding in 2000. The almost eight percent increase in plant cover this year is mainly attributable to increases in perennial plant cover. Perennial plant cover is 17 percent this year, a significant increase over the two percent just two years ago. In contrast, there was only a slight $(0.2$ percent) increase in annual plant cover from 2004 to 2005. There was a flush of growth of native annual plants this spring in adjacent native plant communities.

However, only a few of those species have established on the closure cover. Annual plant cover was essentially non-existent the first couple years and still accounts for less than four percent absolute cover, even with near normal and above normal annual precipitation the last two years. With time more native annual species may invade the site and may contribute more to the overall plant cover. 
The trend in total plant cover over the last four years is as would be expected. After an initial flush of growth the second year after reseeding, due primarily to supplemental irrigation, plant cover declined in 2003 (Figure 6-6). Natural precipitation was below normal in 2003, as it had been in 2002 and 2001. Without supplemental irrigation germination would have been less successful and total plant cover would probably have been even lower than was experienced the first three years after reseeding. It is obvious from the 17 percent plant cover this year that the native plant community on the closure cover is a viable plant cover able to endure the fluctuations in precipitation that is more typical than atypical for this region (Figure 6-7).

The species of plants used in the revegetation process are native to this type of environment and have endured the drought conditions experienced the first several years after reseeding occurred. There may be decreases in plant cover in the future. However, it is evident from the trend in plant cover that although plant cover may decline under adverse growing conditions, when growing conditions do improve there is a corresponding response from the native plants present on the closure cover (Figure 6-6).

Based on revegetation efforts in similar ecoregions, which is a transition between the Mojave Desert and Great Basin, a goal of 12 percent plant cover after five years was established. This doesn't represent the final plant cover expected on the cover cap, but an intermediate stage. The five-year goal was met this year and even exceeded. Actual total plant cover is 20 percent and the majority (17 percent) attributable to perennial native plants; plants that are active for much of the year, unlike the 4-6 weeks of growth of annual plants.

Eventually plant cover should approach 25 percent based on the results of cover estimates for similar plant communities on the Nevada Test Site. Sampling was completed nearly two decades ago and cover values for a shadscale/winterfat plant community were estimated to range from 16-25 percent, a goal attainable in the near future for $\mathrm{U}-3 \mathrm{ax} / \mathrm{bl}$ cover.

Data from the unseeded areas along the periphery of the closure cover, suggests that if the closure cover had not been seeded the composition of plant cover would have been entirely annual plants, most of them weedy, non-native species. Annual plant cover (Table 6-6) may be the same or even higher like this year, but typically cover from annual plants lasts just a few weeks during the year. During periods of drought, as experienced from 2001 to 2003, there were no annual plants to protect the surface soils or to remove even the smallest amounts of soil moisture.

For the third consecutive year plant density has not changed significantly and remains at approximately 4.5 plants $/ \mathrm{m}^{2}$ (Figure 6-7). Such a trend suggests that the plants on the closure cover are well established and utilization of available resources has been optimized. For the most part the vegetative cover on the closure cover is homogeneous with shadscale dominating. There are a few areas, primarily along the western edge of the closure cover, where the density of $K$. lanata, E. nevadensis and A. hymenoides appears higher and A. confertifolia is less dominant.

A. confertifolia, $K$. lanata, and A. hymenoides have shown good growth this year. Plants are flowering and will eventually set seed (Figures 6-4 and 6-5). There is evidence of die-off of a few shadscale plants, but it appears the die-off occurred the first or second year after reseeding because the density of this species has not significantly changed over the last three years. The slight decrease in the density of shadscale was offset with equally slight increases in the density of $K$. lanata, E. nevadensis and A. hymenoides.

The density of annual plants increased this year to 100 plants $/ \mathrm{m}^{2}$ which was 20 plants $/ \mathrm{m}^{2}$ more than last year. Interestingly, the increase in density is not associated with an increase in cover. Cover increased by less than one percent, suggesting that the annual plants are more numerous but smaller. Although annual 
plants may be smaller, the increase is of some concern because $H$. glomerata and B. tectorum account for much of the increase. Both $H$. glomerata and B. tectorum are non-native annual plants which quickly invades disturbed sites. Both species experienced a four-fold increase in plant density from 2003 to 2005. H. glomerata is typically a poor competitor and as native perennial plants become establish H. glomerata is unable to compete for resources and densities remain low and insignificant. No direct impact to native shrub and grass cover or density due to the increased density of $H$. glomerata was observed on the closure cover this year.

The plant community on the closure cover is becoming well established (Figure 6-8). The density of perennial plant species has remained the same over the last three years. Plant cover has increased to over 20 percent well above the goal of 12 percent. There is no indication that remedial revegetation is necessary. Vegetation monitoring in future years should focus on annual weedy species, specifically H. glomerata, B. tectorum, and S. tragus. If these species increase in density and cover, and appear to have a detrimental effect on the perennial plant species, as evidenced by decreases in perennial plant cover and/or density, some remedial action may be necessary to protect the composition and stability of the vegetative cover on the CAU 110, U-3ax/bl closure cover. 


\section{PERCENT PLANT COVER}

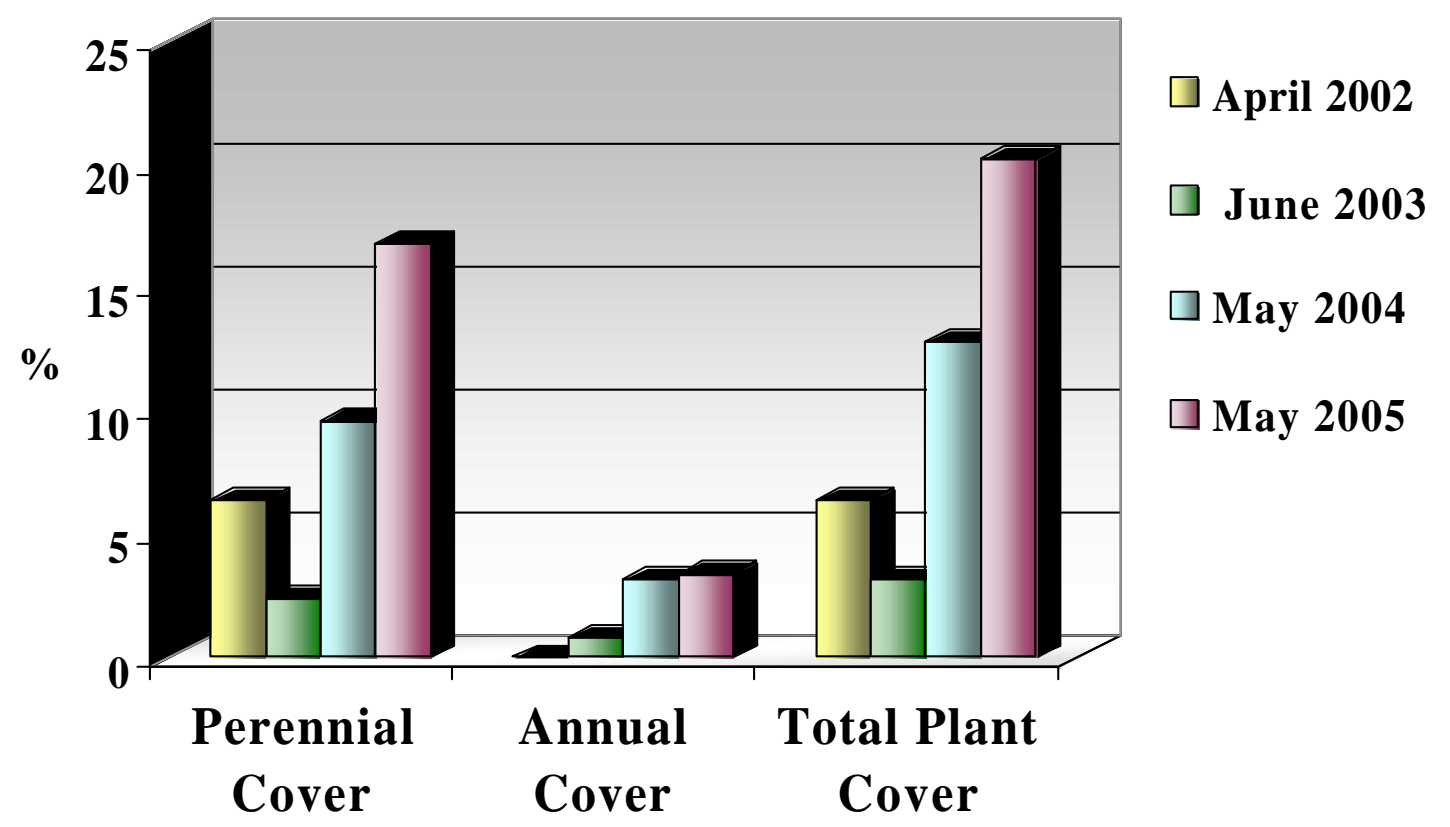

Figure 6-6. Summary of total plant cover on U-3ax/bl closure cover from April 2002 to May 2005.

\section{PLANT DENSITY}

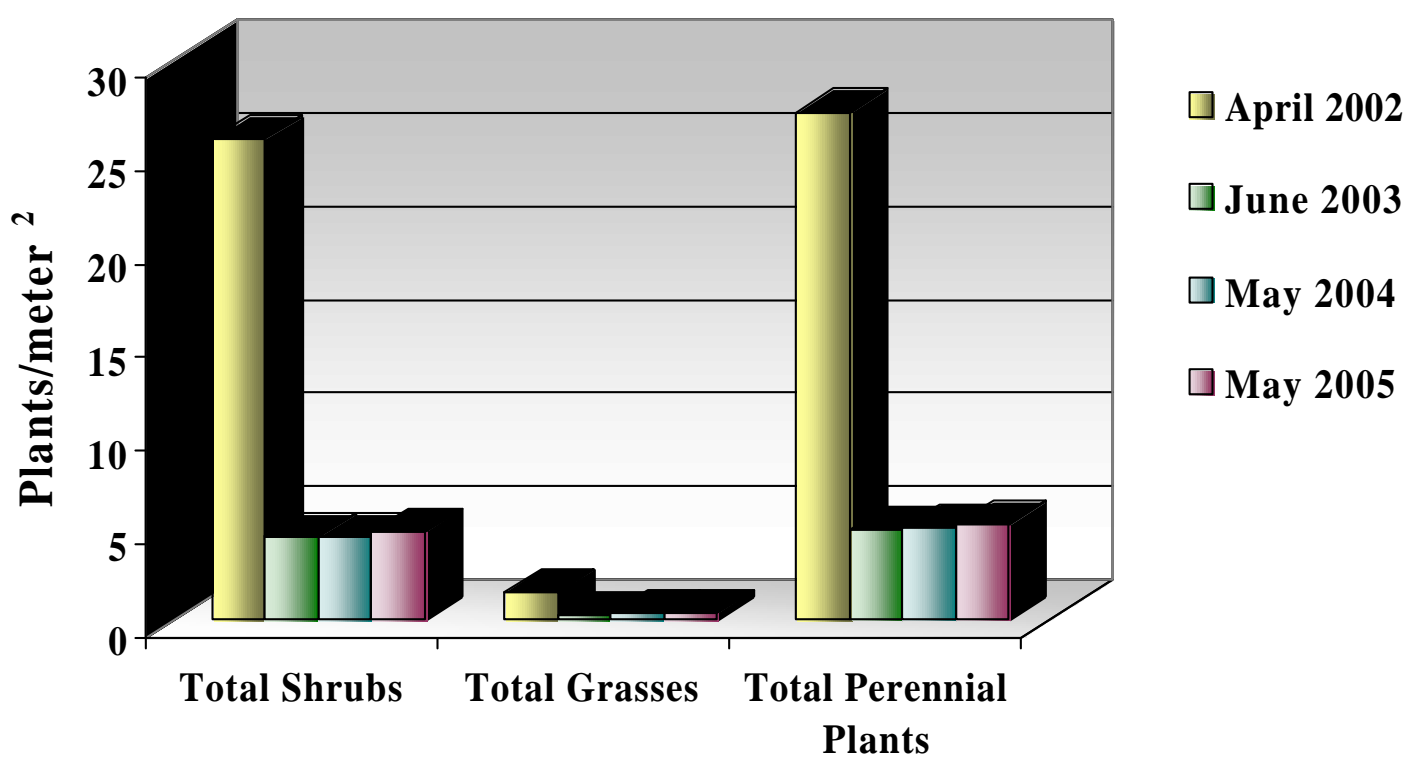

Figure 6-7. Summary of perennial plant density on U-3ax/bl closure cover from April 2002 to May 2005. 

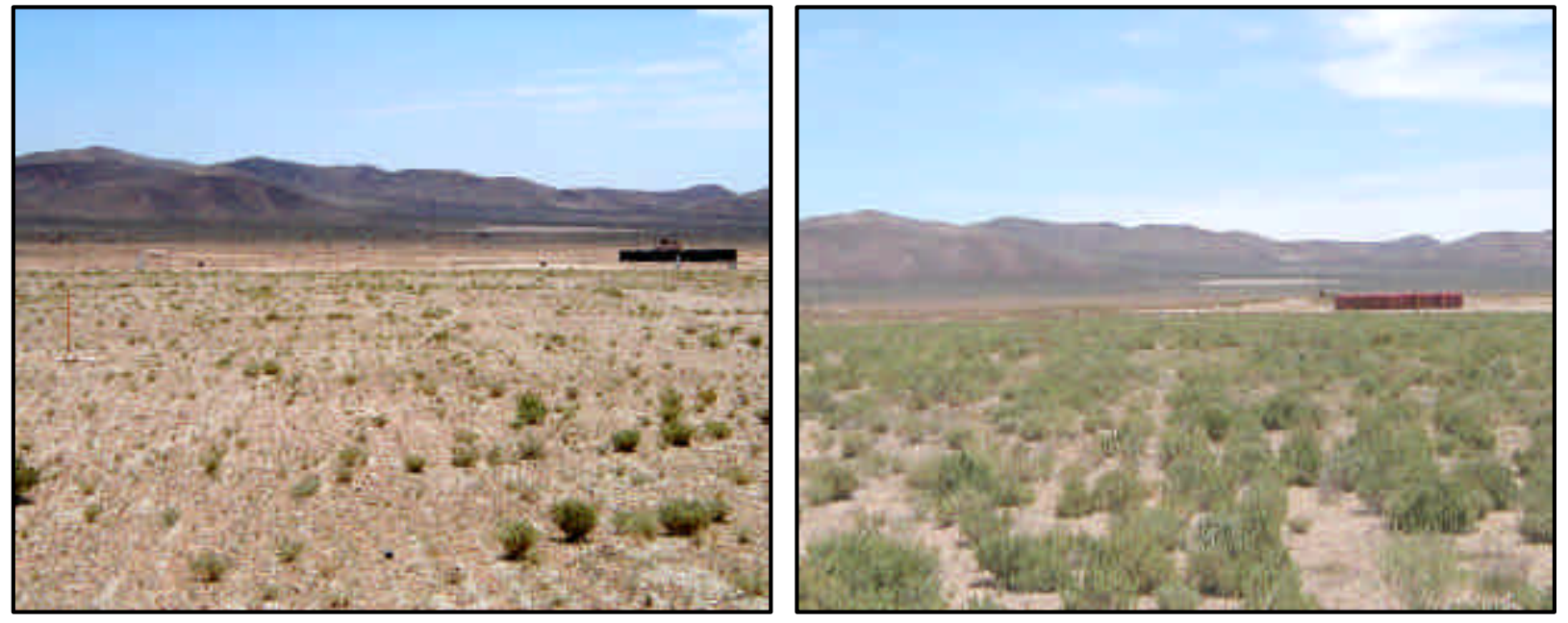

Figure 6-8. Comparison of vegetative cover, growth, and establishment on CAU 110, U-3ax/bl closure cover. Photos were taken by Dave Anderson in June 2003 (left) and June 2005 (right). 


\subsubsection{Maintaining Closure Cover Integrity at CAU 110, U-3ax/bl}

With the establishment of vegetation on the closure cover came a corresponding influx of small mammals and small mammal burrows. A concern was expressed that the closure cover structure may be comprised with the burrowing animals. In April 2005 an initiative began with the objective of removing burrowing animals from the closure cover. Fifty-two small mammal traps were placed in clusters and in close proximity to active small mammal burrows on the closure cover. Another 44 traps were placed along the peripheral fence where there was also an abundance of active small mammal burrows. Six traps were added during the June session making a total of 102 traps. Traps were baited with a custom mixture of bird seed and oats. Six traps nights were completed in April, three in June and three in September.

During the six trapping nights in April 130 animals were removed from the closure cover and relocated approximately five miles from the site. During the week of June $14^{\text {th }}$, another 26 animals were captured and relocated (Table 6-5) during three trap nights. During the final trapping session in September 2005, 34 animals were captured and relocated for a total of 190 animals captured and relocated during the three trapping sessions. Three-fourths of the animals captured and relocated were Merriam's kangaroo rats (Dipodomys merriami), one longtailed pocketmouse (Onychomys torridus) was captured representing less than 1 percent and deer mice (Peromyscus maniculatus) captures made up the remaining 25 percent.

Table 6-5. Number of small mammals relocated from U-3ax/bl closure cover and adjacent areas in 2005.

\begin{tabular}{|c|c|c|c|c|c|c|c|c|c|}
\hline & \multicolumn{3}{|c|}{ April } & \multicolumn{3}{|c|}{ June } & \multicolumn{3}{|c|}{ September } \\
\hline & Cover & Periphery & Total & Cover & Periphery & Total & Cover & Periphery & Total \\
\hline $\begin{array}{l}\text { Merriam's } \\
\text { Kangaroo Rat }\end{array}$ & 57 & 42 & 99 & 5 & 13 & 18 & 4 & 22 & 26 \\
\hline $\begin{array}{l}\text { Long-tailed } \\
\text { Pocket mouse }\end{array}$ & 1 & 0 & 1 & 0 & 0 & 0 & 0 & 0 & 0 \\
\hline Deer Mouse & 13 & 17 & 30 & 8 & 0 & 8 & 6 & 2 & 8 \\
\hline Total: & 71 & 59 & 130 & 13 & 13 & 26 & 10 & 24 & 34 \\
\hline
\end{tabular}




\subsection{MONITORING OF THE NON-POLIFERATION TEST AND EVALUATION COMPLEX}

\subsection{Task Description}

Biological monitoring at the Non-Proliferation Test and Evaluation Complex (NPTEC; formerly the Hazardous Materials Spill Center) on the playa of Frenchman Lake in Area 5 is performed, if necessary, for certain types of chemical releases as per the center's programmatic Environmental Assessment. In addition, ESHD has requested that BN monitor any test which may impact plants or animals downwind which are off the playa. A Biological Monitoring Plan for NPTEC was prepared in FY 1996 and updated in FY 2002 (BN, 2002). It describes how field surveys will be conducted to determine test impacts on plants and animals and to verify that the center's program complies with pertinent state and federal environmental protection legislation. The design of the monitoring plan calls for the establishment of three control transects and three treatment transects at three distances from the main chemical release points on the playa. The control and treatment transects have similar environmental and vegetation characteristics.

$\mathrm{BN}$ biologists are tasked to review chemical release test plans to determine if field monitoring along the treatment transects is required for each test as per the monitoring plan criteria. All test-specific field monitoring is funded through the NPTEC. Since 1996, the majority of chemical releases being studied at the center have used such small quantities that downwind test-specific monitoring has not been necessary.

\subsection{Task Progress Summary}

BN reviewed chemical spill test plans for the following two activities in 2005: Divine Shrake and Scorpion. Chemicals were released at such low volumes or low toxicity that there was no need to monitor downwind transects for biological impacts.

Baseline monitoring was conducted at established control-treatment transects near the NPTEC in AprilMay and September-October. This monitoring noted the condition of plants and the presence of wildlife sign during the period of vegetative growth and following summer drought, respectively. No differences in biota were noted along downwind (treatment) versus upwind (control) transects. Baseline monitoring data are collected to document any cumulative impacts over time of test center activities on biota downwind of the facility. These data are made available to neighboring land managers upon request. 
THIS PAGE IS INTENTIONALLY LEFT BLANK 


\subsection{LITERATURE CITED}

Barneby, R.C. 1970. A new Astragalus from Nye county, Nevada. Aliso 7:161-163.

Bechtel Nevada, 2001. Adaptive Management Plan for Sensitive Plant Species on the Nevada Test Site. DOE/NV/11718-507, Bechtel Nevada, Las Vegas, NV, March 2001.

Bechtel Nevada, 2002. Nevada Test Site Wildland Fire Management Plan, Revision 0, March 11, 2002. Submitted by letter to T. Wallace, NNSA/NSO from T. Habermas, BN, Correspondence No. A400-TH-02-0005, March 27, 2002.

Bechtel Nevada, 2002. Biological Monitoring Plan for Hazardous Materials Spill. March 2002, Bechtel Nevada, Environmental Monitoring, Ecological Services, Las Vegas, Nevada.

Benson. L. 1982. Cacti of the United States and Canada. Stanford University Press, California, USA.

Blomquist, K. W., C. A. Wills, W. K. Ostler, K. R. Rautenstrauch and T. P. O'Farrell, 1992. Distribution, Life History, Management, and Current Status of Astragalus beatleyae on the U.S. Department of Energy's Nevada Test Site. EGG10617-2187, EG\&G Energy Measurements, Santa Barbara Operations, Goleta, California, November 1992.

Blomquist, K. W., T. A. Lindemann, G. E. Lyon, D. C. Steen, C. A. Wills, S. A. Flick, and W. K. Ostler, 1995. Current Distribution, Habitat, and Status of Category 2 Candidate Plant Species on and Near the U.S. Department of Energy's Nevada Test Site. EGG11265-1149, EG\&G Energy Measurements, Las Vegas, Nevada, December 1995.

BN, see Bechtel Nevada.

CRWMS\&O, see Civilian Radioactive Waste Management System Management and Operating Contractor

Civilian Radioactive Waste Management System Management and Operating Contractor. 1997. Abundance and Species Composition of Rodent Populations at Yucca Mountain, Nevada. B00000000-01717-5705-00034. Revision 00. Las Vegas, Nevada.

DOE/NV, see U.S. Department of Energy Nevada Operations Office.

Flowers, S. 1973. Mosses: Utah and the West. Brigham Young University Press, Provo, UT, USA.

FWS, see U.S. Fish and Wildlife Service.

Greger, P. D. and E. M. Romney, 1994. Trends in Wildlife Utilization of Water Source and Adjacent Habitats at the Nevada Test Site 1989-91. In: Status of the Flora and Fauna on the Nevada Test Site 1989-91. Compiled by R. B. Hunter, DOE/NV/11432-57, Reynolds Electrical \& Engineering Co., Inc., Las Vegas, Nevada.

Greger, P. D. and E. M. Romney, 1999. High foal mortality limits growth of a desert feral horse population in Nevada. Great Basin Naturalist 59:374-379. 
Hansen, D.J., P. D. Greger, C.A. Wills. 1997. Nevada Test Site Wetlands Assessment. DOE/NV/11718124, Bechtel Nevada, Ecological Services, Las Vegas, Nevada.

Hansen, Dennis J. and W. Kent Ostler. 2004. A survey of vegetation and wildland fire hazards on the Nevada Test Site. DOE/NV/11718-981. September 2004. Bechtel Nevada, Ecological Services, Las Vegas, Nevada.

Hunter, R. B., E. M. Romney, and A. Wallace, 1980. Fencing enhances shrub survival and growth for Mojave Desert revegetation. Great Basin Naturalist Memoirs No. 4:212-215.

Hunter, R. B., E. M. Romney, and A. Wallace, 1987. Revegetation on disturbed desert land at NUWAX and SEDAN. In: The Dynamics of Transuranics and Other Radionuclides in Natural Environments. Howard, W. A., and R. G. Fuller (Eds.). U.S. Department of Energy, Nevada Operations Office, Las Vegas, Nevada. NVO-272, pp. 79-97.

NNSA/NV, see U.S. Department of Energy, National Nuclear Security Administration Nevada Operations Office.

Nevada Bat Working Group. 2002. Draft Nevada Bat Conservation Plan. Austin, Nevada. 188pp.

Ostler, W.K., D. J. Hansen, D.C. Anderson and D.B. Hall, 2000. Classification of Vegetation on the Nevada Test Site. DOE/NV/11718--477, Bechtel Nevada Ecological Services, Las Vegas, Nevada.

Peterson, F.F., 1981. Landforms of the Basin \& Range Province Defined for Soil Survey. Technical Bulletin 28, Nevada Agricultural Experiment Station, University of Nevada Reno, January 1981.

Romney, E. M., A. Wallace, and R. B. Hunter, 1989. Transplanting of native shrubs on disturbed land in the Mojave Desert, pp. 50-53. In: Proceedings of the Symposium on Shrub Ecophysiology and Biotechnology; 1987 June 30 - July 2: Logan, UT. Wallace, A., E. D. McArther, and M. R. Haferkamp (Compilers). General Technical Report INT-256, U.S. Department of Agriculture, Forest Service, Intermountain Research Station, Ogden, Utah.

Saethre, M. B. 1995. Small Mammal Populations On the Nevada Test Site. In: Status of the Flora and Fauna on the Nevada Teat Site, 1994. Compiled by R. B. Hunter, DOE/NV/11432-195, Reynolds Electrical \& Engineering Co., Inc., Las Vegas, Nevada.

Shabbara, H.M. 1999. Three new records of Funariaceae from Egypt. Journal of Bryology 21: 201-205.

Stark, L. R., A. T. Whittemore, and B. D. Mishler. 2002. Noteworthy bryophyte records from the Mojave Desert. Madroño 49: 49-53.

Turner, J.W., Jr., M. L. Wolfe, and J. F. Kirkpatrick. 1992. Seasonal mountain lion Predation on a feral horse population. Canadian Journal of Zoology. 70: 929-934.

U.S. Department of Energy. 2002a. A Graded Approach for Evaluating Radiation Doses to Aquatic and Terrestrial Biota, DOE-STD-1153-2002, U.S. Department of Energy, Washington, D.C. 
U.S. Department of Energy, National Nuclear Security Administration Nevada Operations Office, 2002b. Nevada Test Site Orthophoto Site Atlas. DOE/NV/11718-604. Geographic Information Systems Section, Remote Sensing Department, Bechtel Nevada, Las Vegas, Nevada.

U.S. Department of Energy Nevada Operations Office, 1996. Final Environmental Impact Statement for the Nevada Test Site and Off-Site Locations in the State of Nevada, Volume 1, Chapters 1-9. DOE/EIS 0243, Las Vegas, Nevada, August 1996.

U.S. Department of Energy Nevada Operations Office, 1998. Nevada Test Site Resource Management Plan, DOE/NV-518, Las Vegas, NV, December 1998.

U.S. Department of Energy Nevada Operations Office, Undated (about 1996). Nevada Test Site Grid Map. ER\&NP Division, EG\&G, Las Vegas, Nevada.

U.S. Fish and Wildlife Service, 1996. Final Programmatic Biological Opinion for Nevada Test Site Activities. File No. 1-5-96-F-33, August 22, 1996, Reno, Nevada.

Wallace, A. and E. M. Romney, 1977. Initial land reclamation procedures related to possible Pu-cleanup activities at the Tonopah Test Range. In: Environmental Plutonium on the Nevada Test Site and Environs. White, M. G., P. B. Dunaway, and W. A. Howard (Eds.). NVO-171, Nevada Applied Ecology Group, U.S. Energy Research \& Development Administration, Las Vegas, Nevada, pp. 65-77.

Wallace, A., E. M. Romney, and R. B. Hunter. 1977. The challenge of a Desert: Revegetation of Disturbed Lands. In: Transuranics in Desert Ecosystems. White, M. G., and P. B. Dunaway (Eds.). NVO-181. U.S. Department of Energy, Nevada Operations Office, Las Vegas, NV, pp. $17-40$.

Wallace, A. and E. M. Romney, 1980. The role of pioneer species in revegetation of disturbed desert areas. Great Basin Naturalist Memoirs 4:31-33.

Wallace, A., E. M. Romney, and R. B. Hunter, 1980. The challenge of a desert: revegetation of disturbed desert lands. Great Basin Naturalist Memoirs 4:216-225.

Western Bat Working Group. 1998. Western Bat Species: Regional Priority Matrix. 
THIS PAGE IS INTENTIONALLY LEFT BLANK 


\section{Appendix A - Selected Photographs of NTS Sites with Various Fuel Ratings}

The abundance of fine-textured (grasses and herbs) and coarse-textured (woody) fuels were initially visually estimated on numerical scales ranging from one to five (1=very low, $2=$ low, $3=$ moderate, 4=high, $5=$ very high). However, field observations suggested a need to further differentiate subtle differences between fuels at sites with similar ratings. Therefore, each numerical scale was expanded by one-half of a scale value or integer. Additionally, sites where there were no fuels (barren) were rated as 0 (zero). This resulted in the following 10-point potential scale: $0,1,1.5,2,2.5,3,3.5,4,4.5$, and 5 .

Photographs of sites typifying some of these scale values are found in this Appendix. 
Wildland Fire Woody Fuels Index $=1$

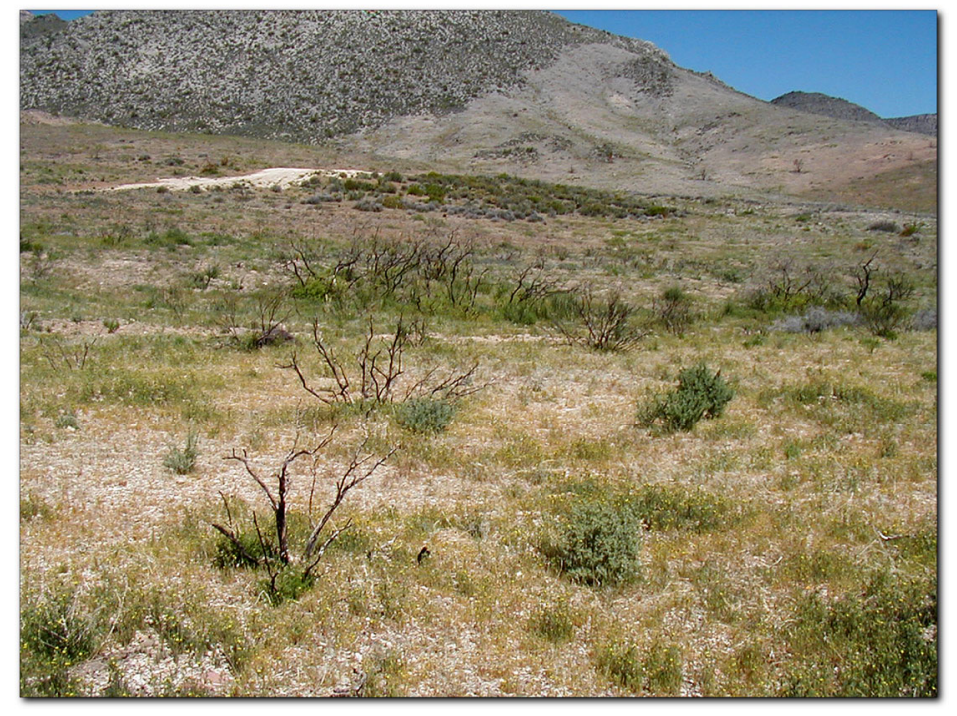

20041111.JPG

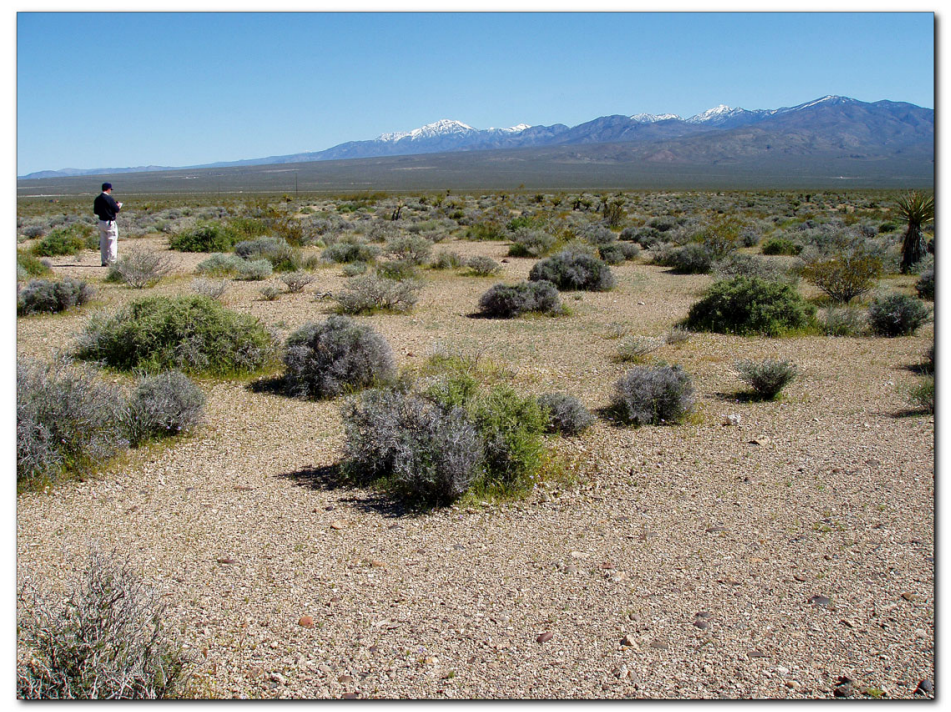

20050211.jpg

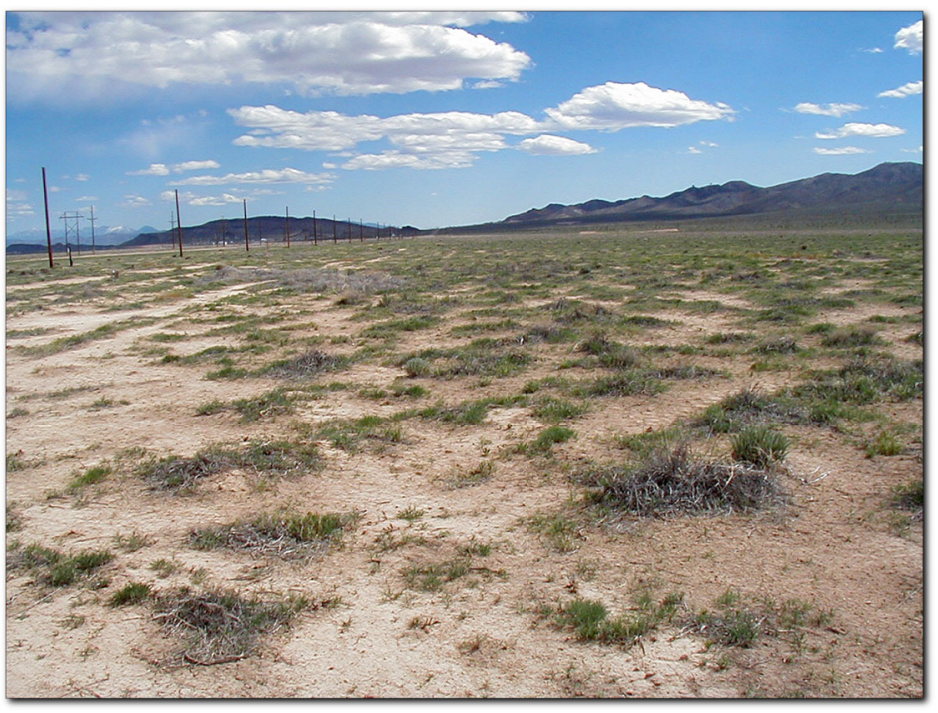

20041241.JPG

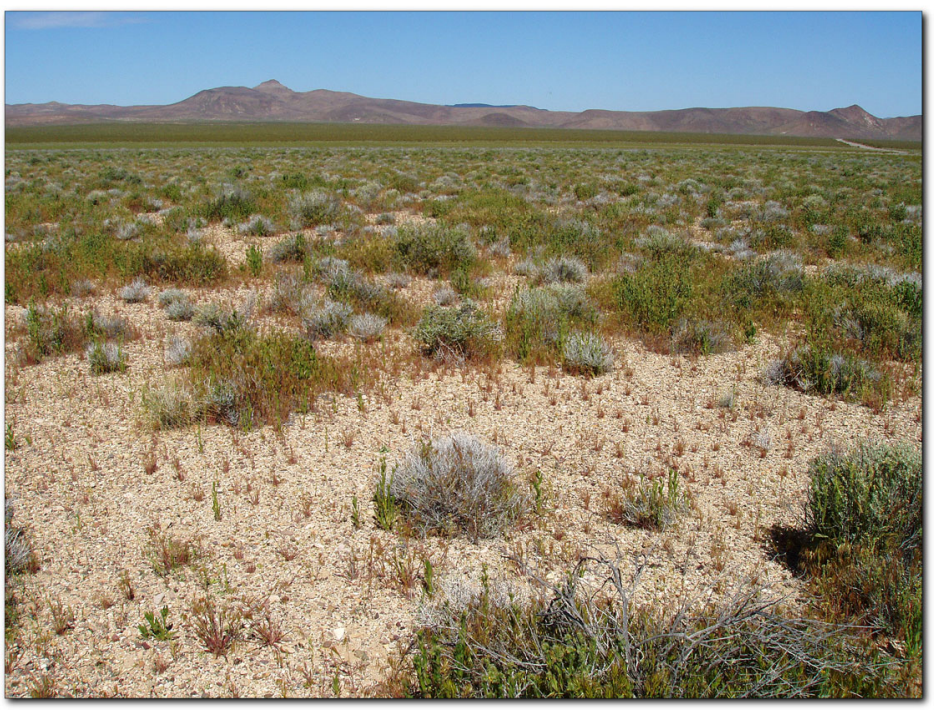

20050401.JPG 
Wildland Fire Woody Fuels Index $=2$

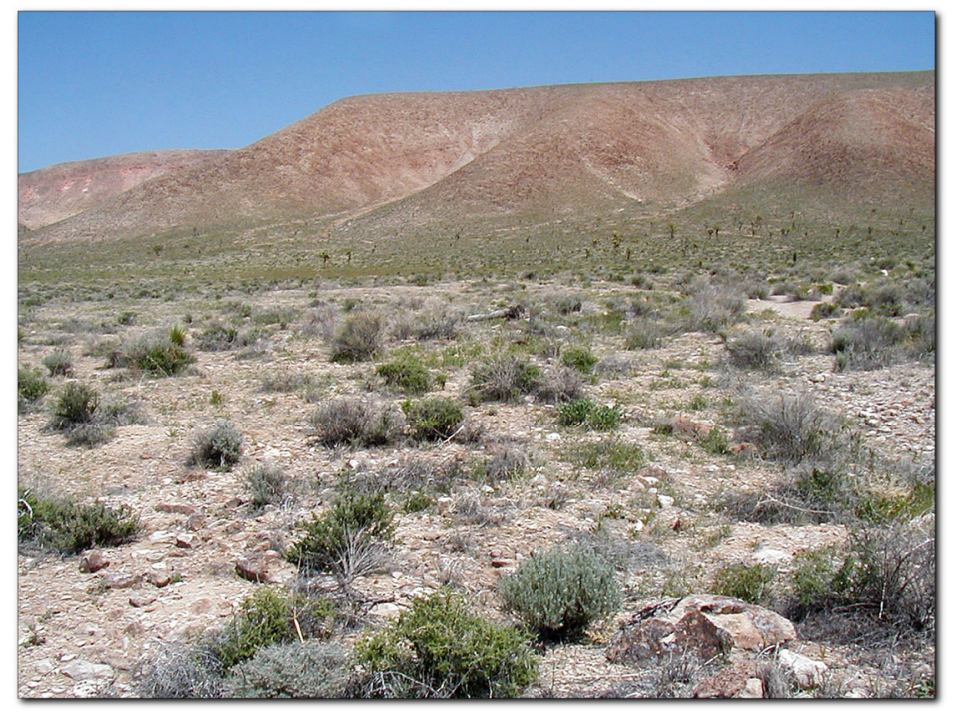

20040821.JPG

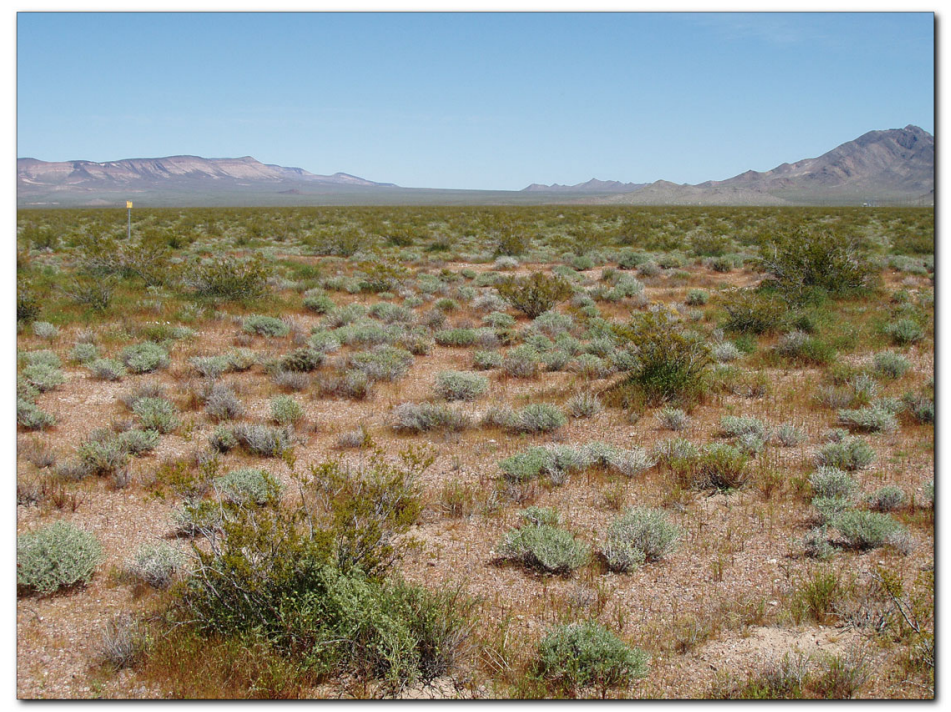

20050011.JPG

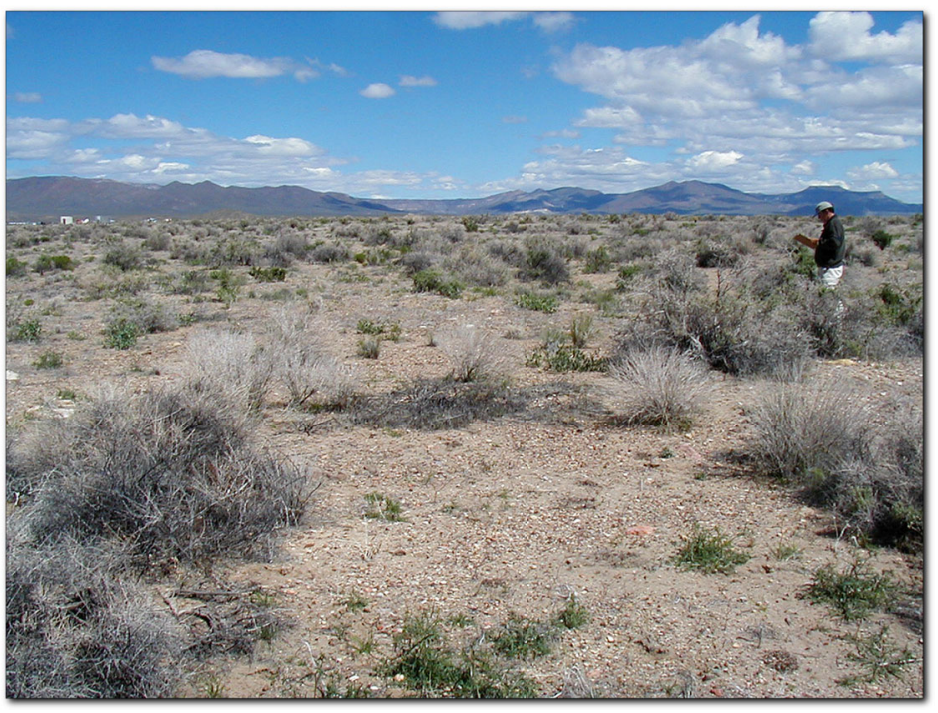

20041001.JPG

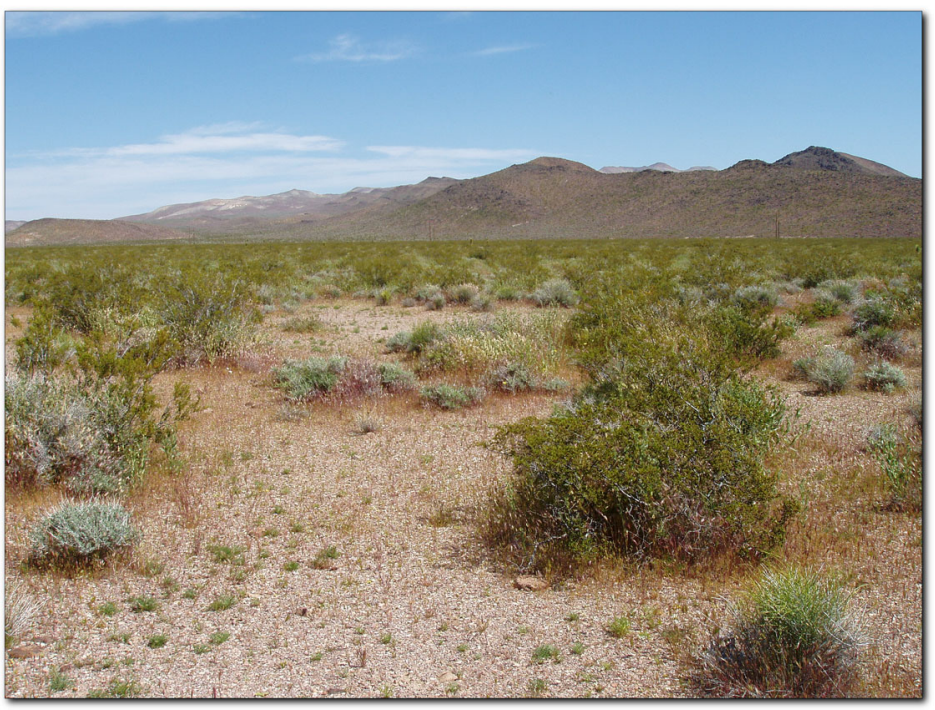

20050371.JPG 
Wildland Fire Woody Fuels Index $=3$

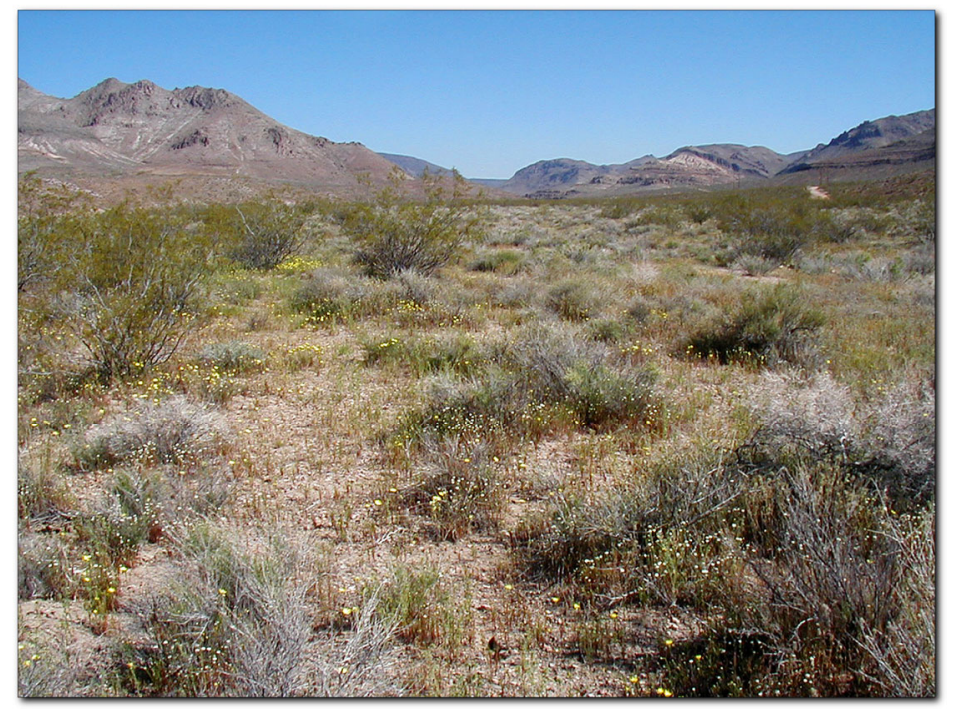

20040601.JPG

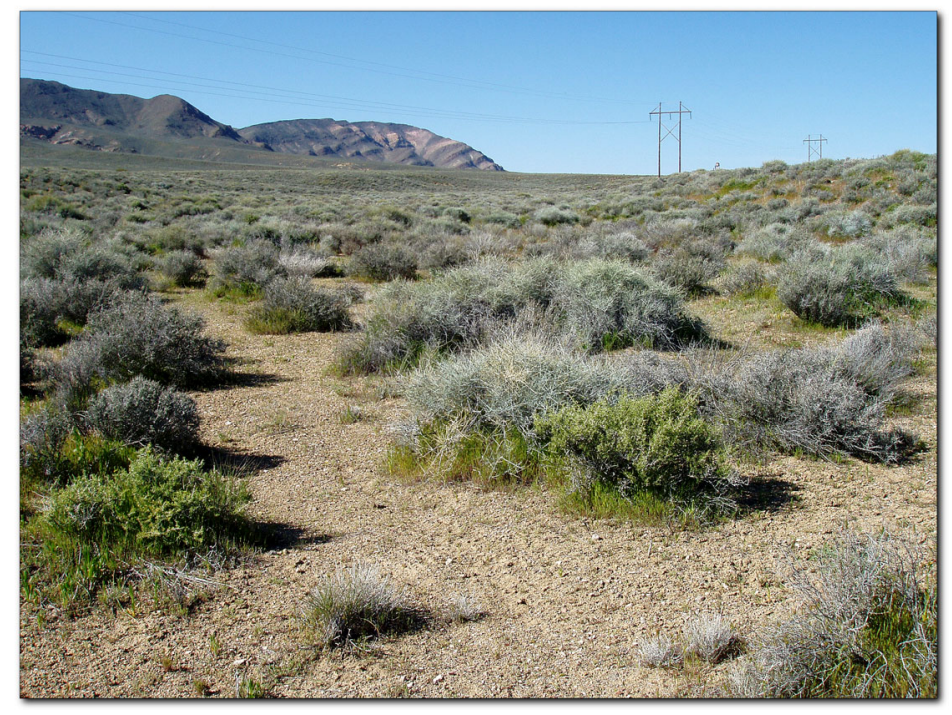

20050301.JPG

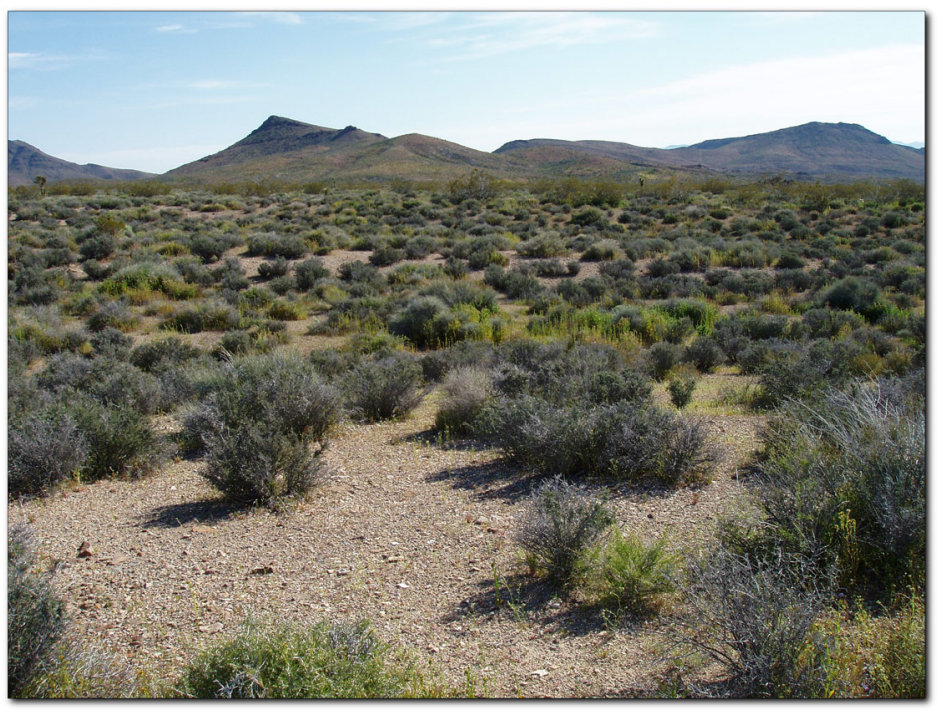

20050291.JPG

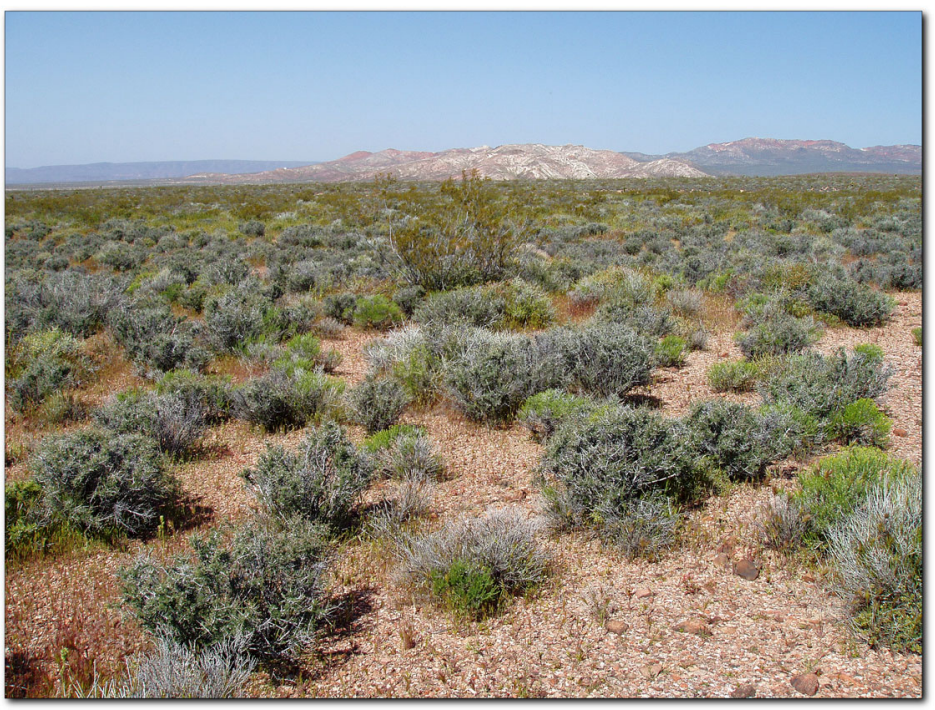

20050741.JPG 
Wildland Fire Woody Fuels Index $=4$

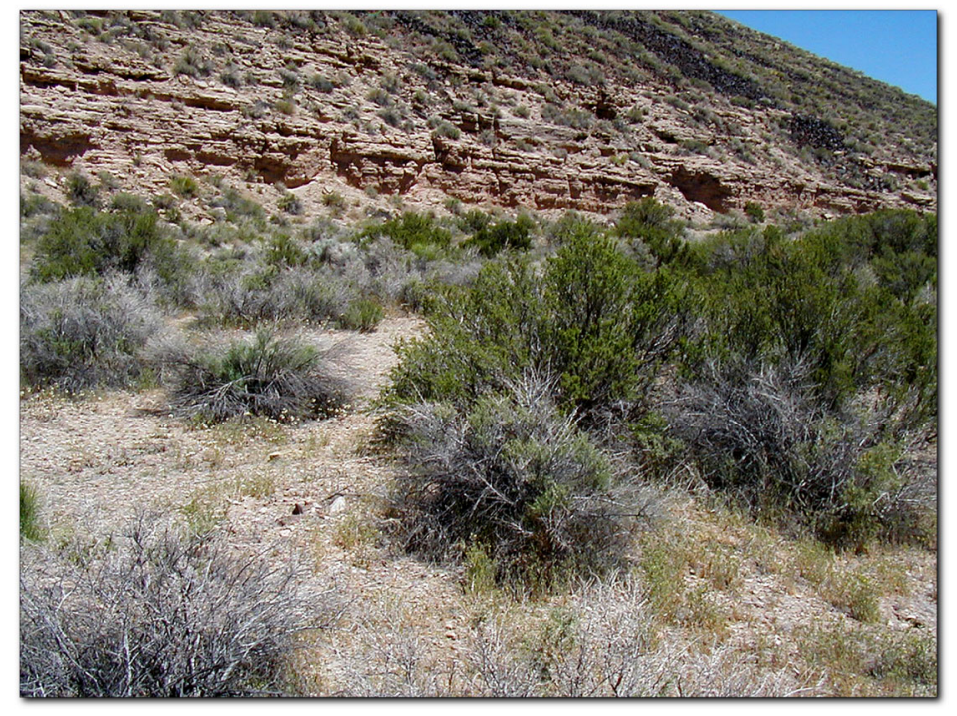

20041811.JPG

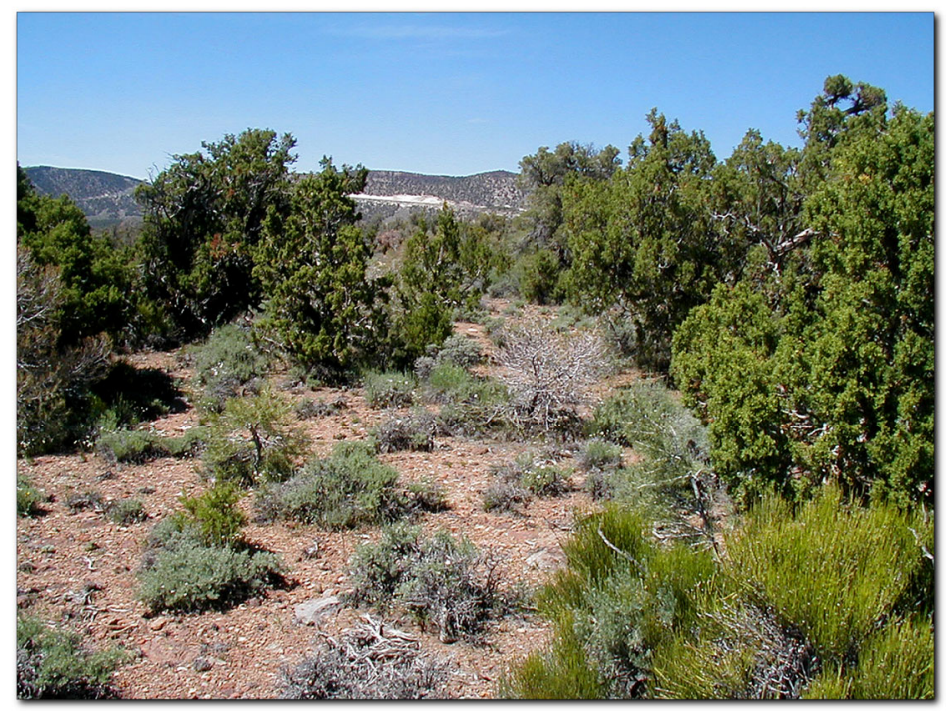

20042101.JPG

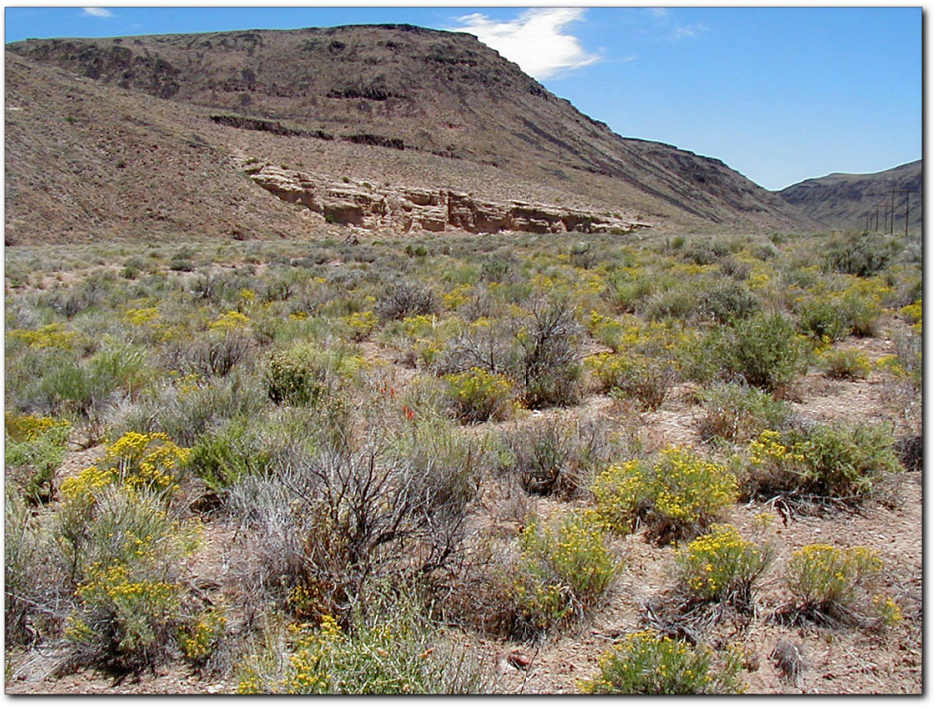

20041841.JPG

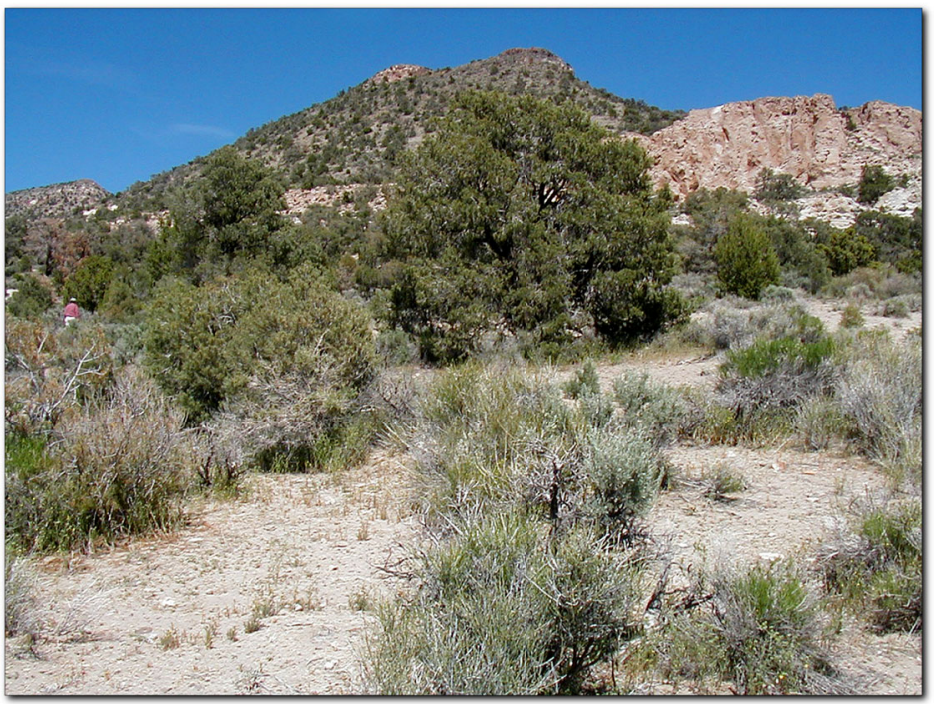

20042111.JPG 
Wildland Fire Woody Fuels Index $=5$

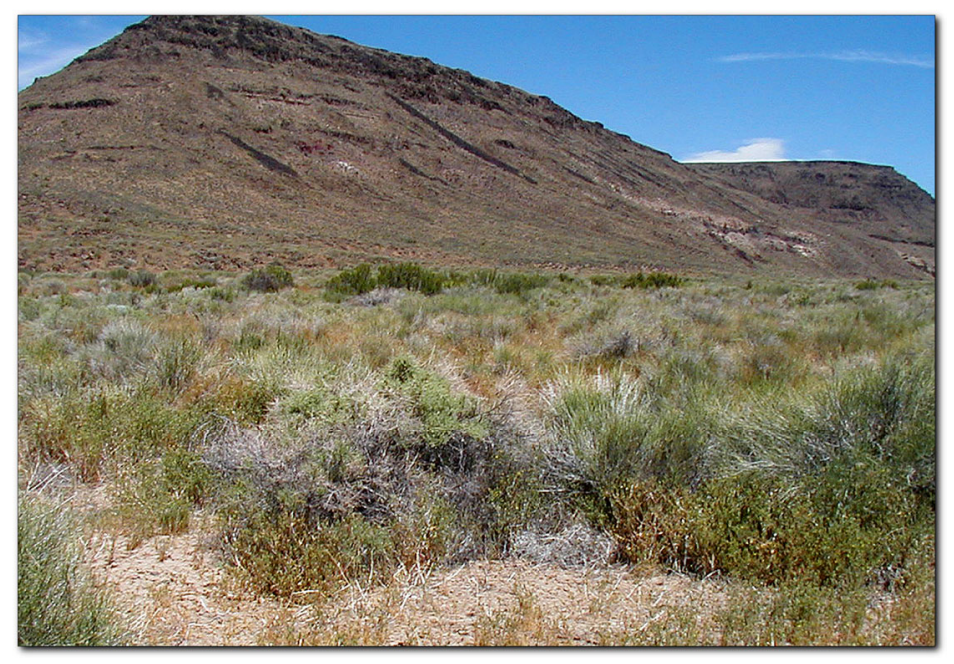

20041851.jpg

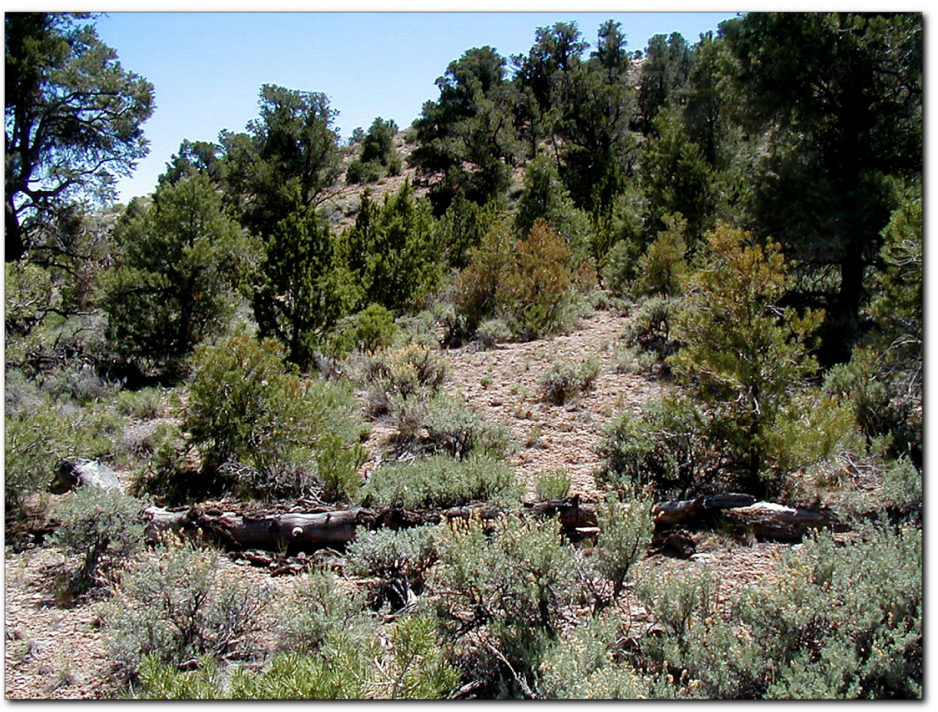

20042061.JPG

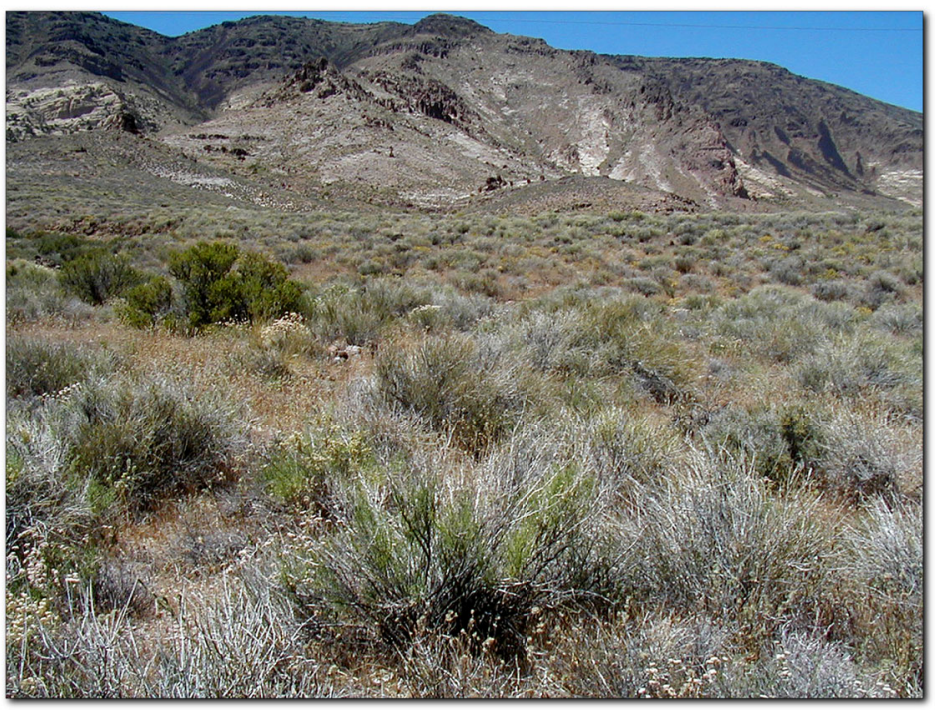

20041921.JPG

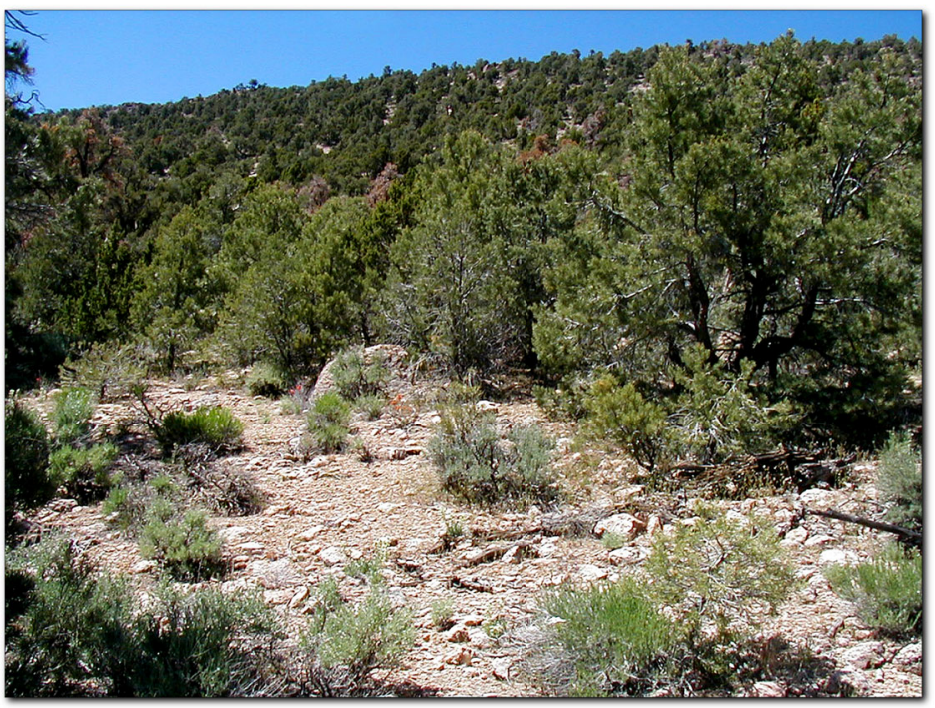

20042091.JPG 
Wildland Fire Fine Fuels Index $=1$
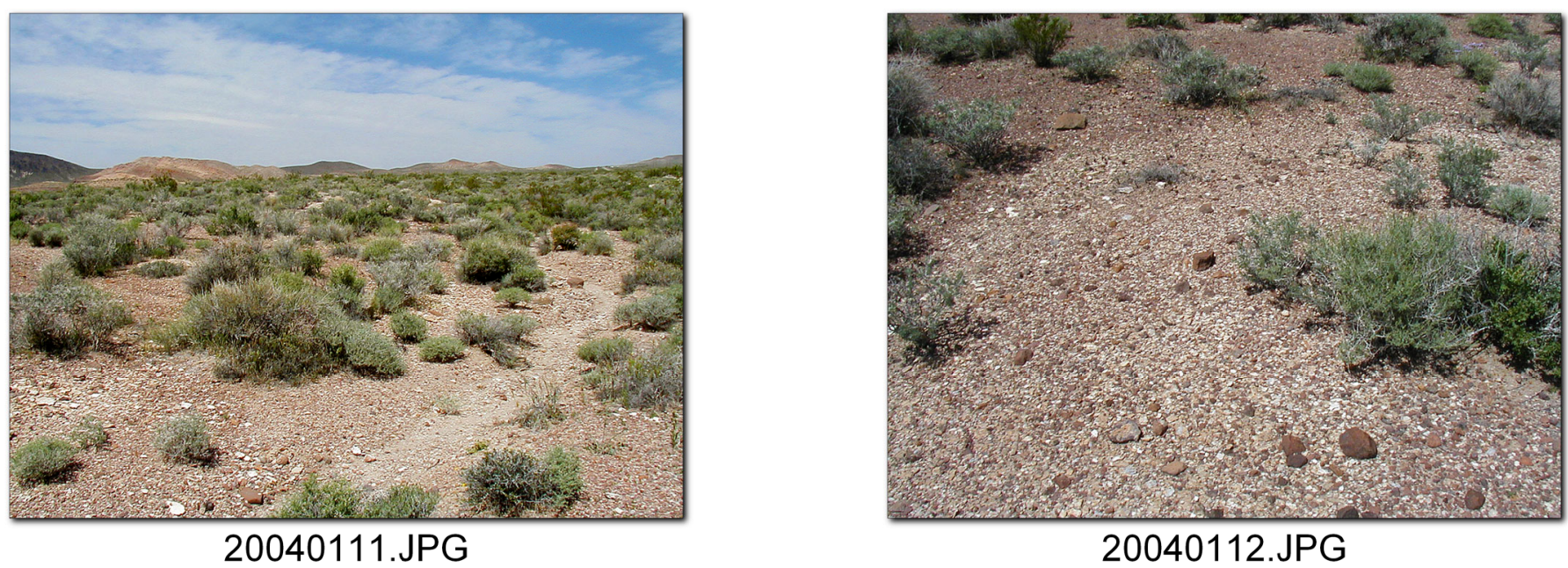

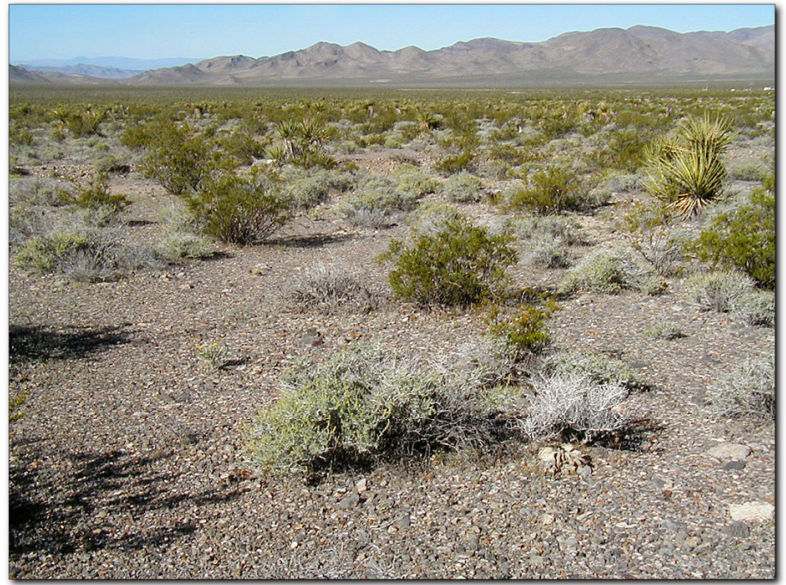

20040241.JPG

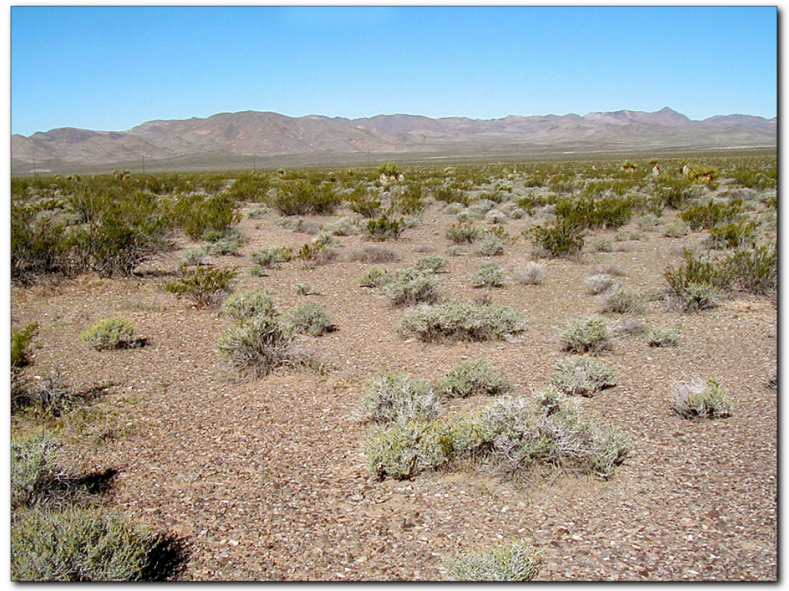

20040251.JPG

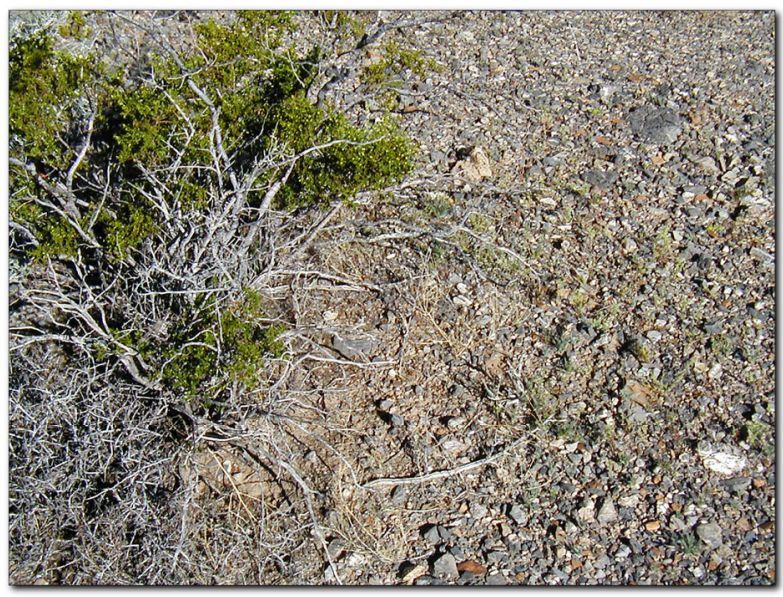

20040242.JPG

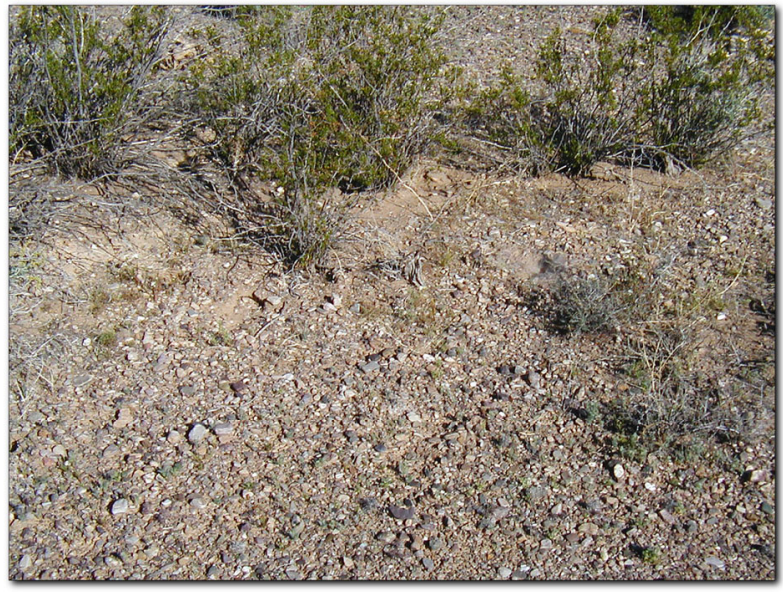

20040252.JPG 
Wildland Fire Fine Fuels Index $=2$

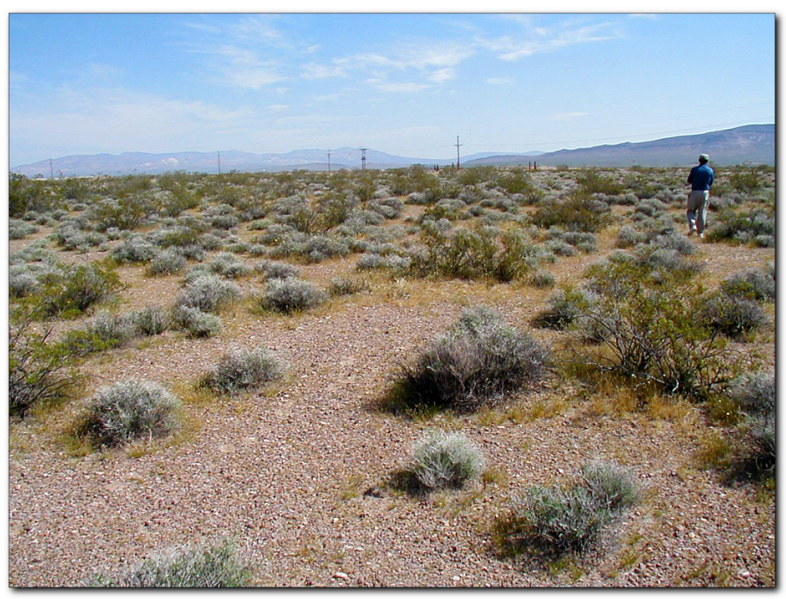

20040021.JPG

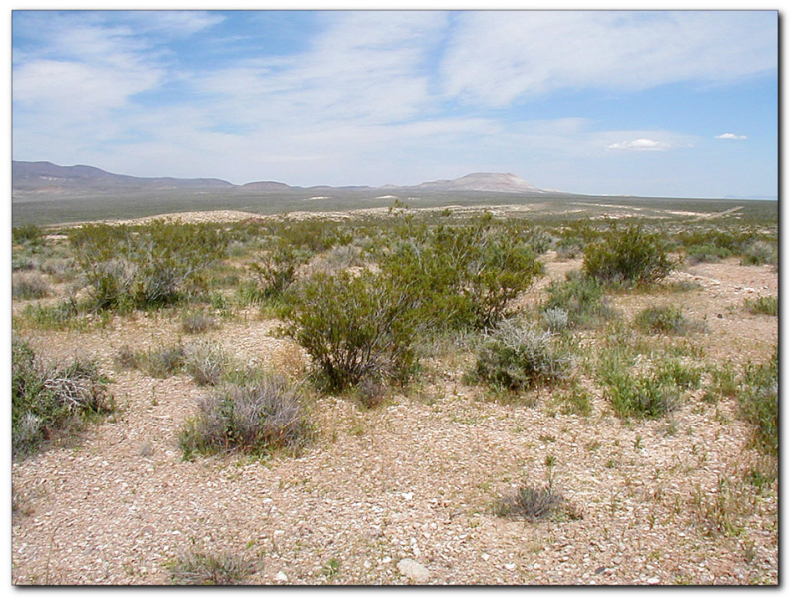

20040131.JPG

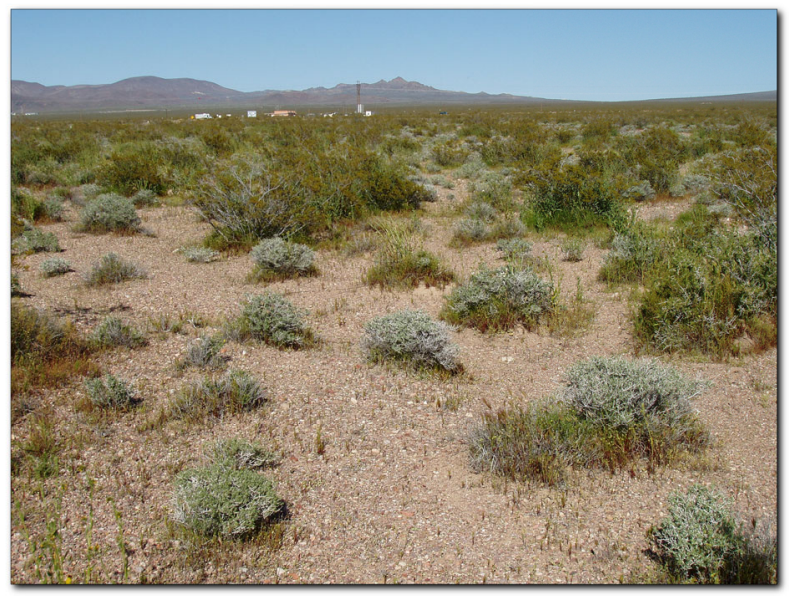

20050071.JPG

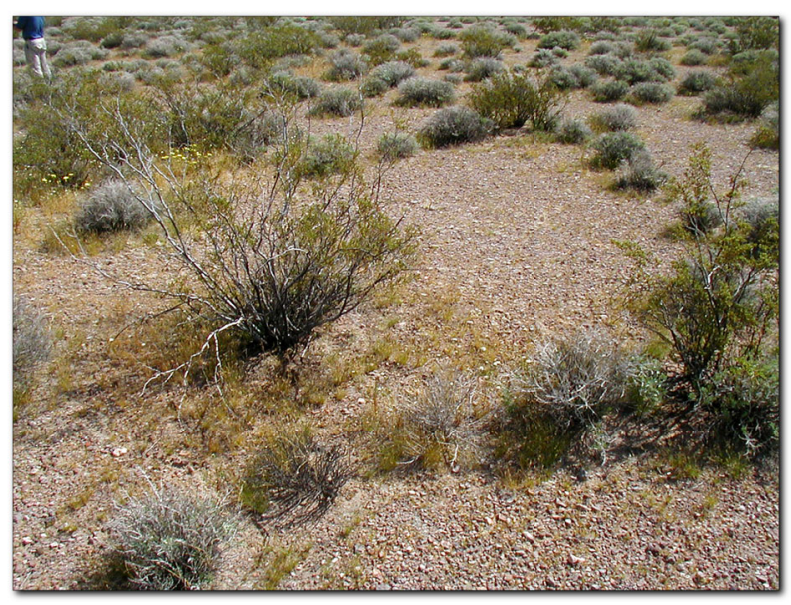

20040022.JPG
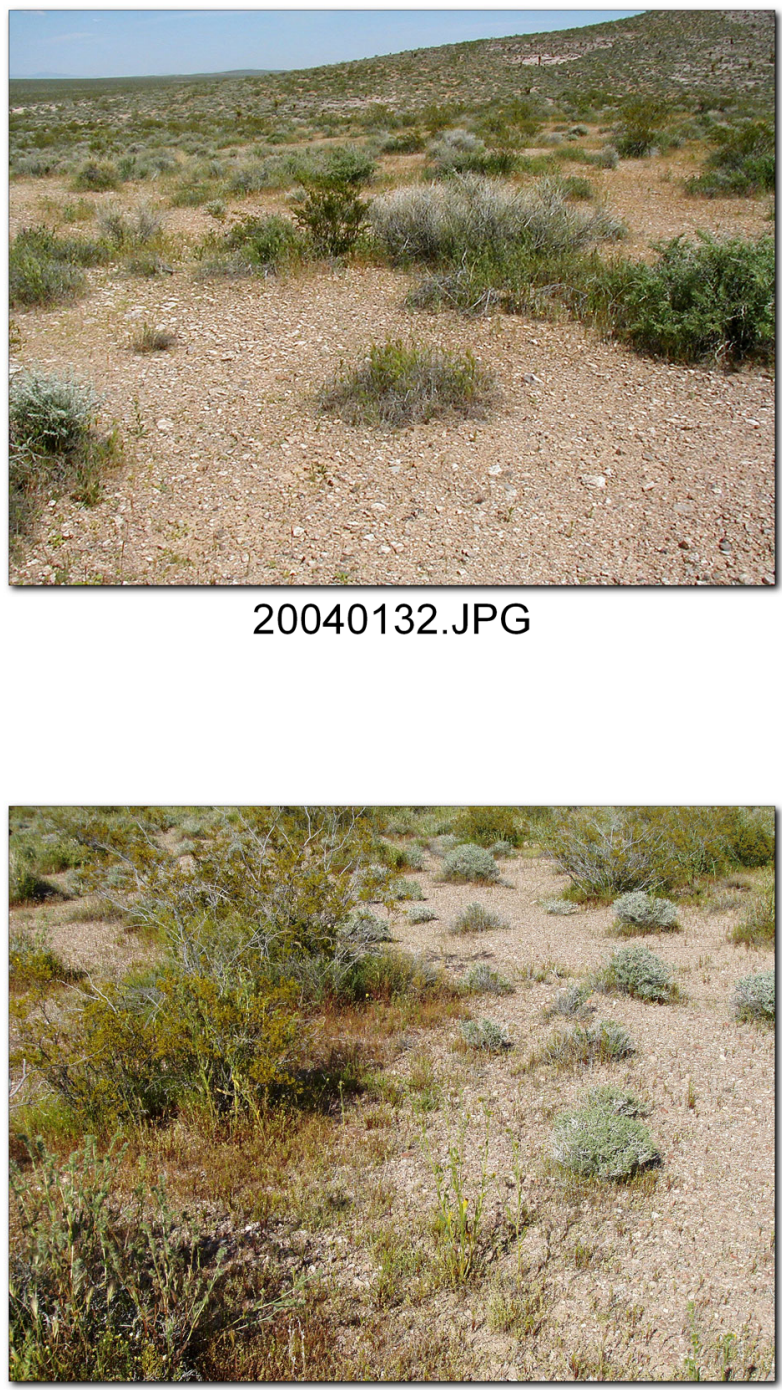

20050072.JPG 
Wildland Fire Fine Fuels Index $=3$

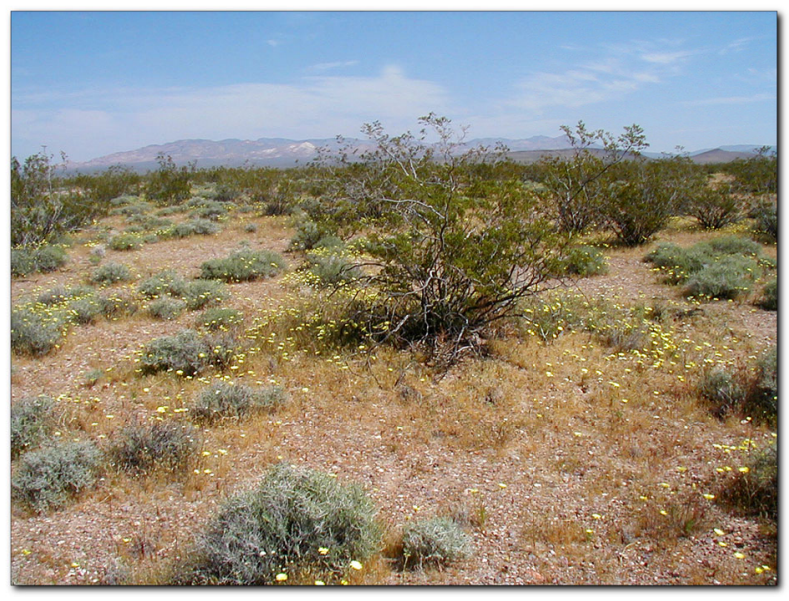

20040041.JPG

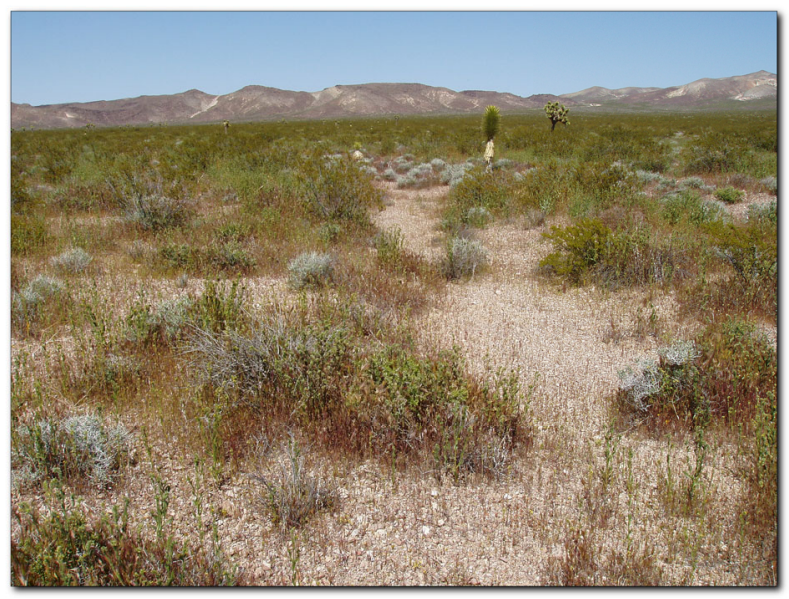

20050501.JPG

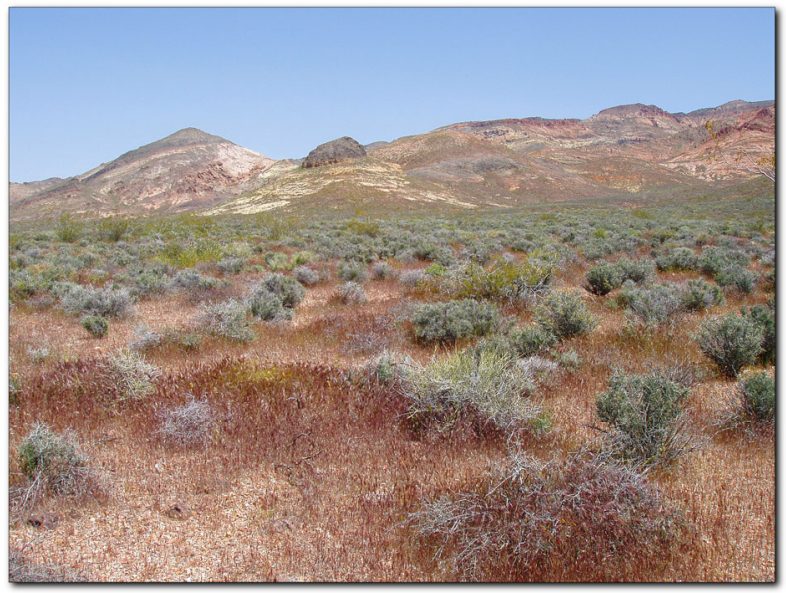

20050641.JPG
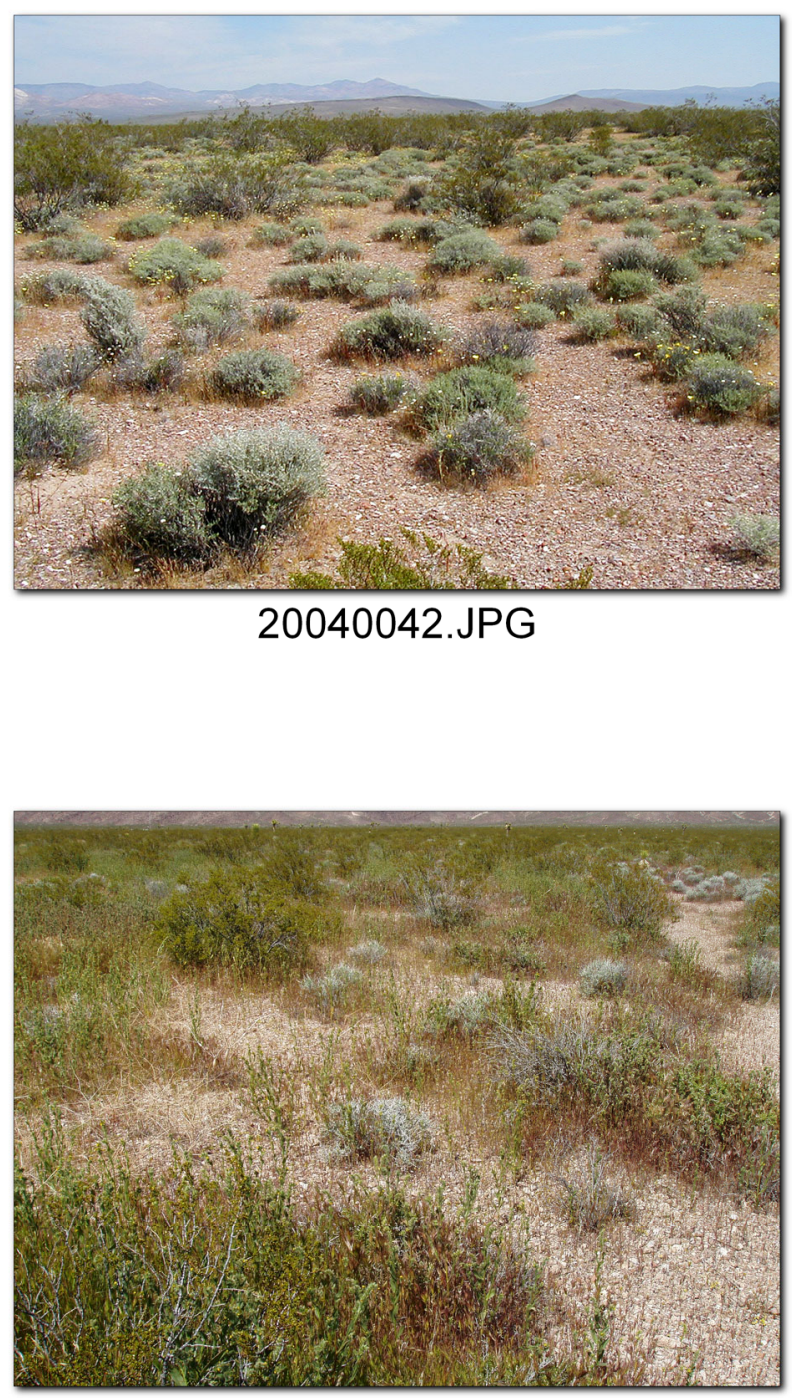

20050502.JPG

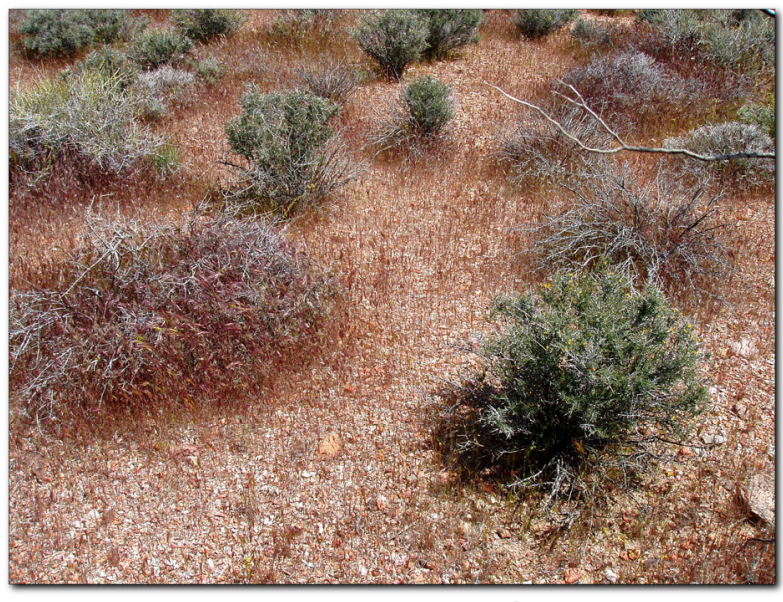

20050642.JPG 
Wildland Fire Fine Fuels Index $=4$

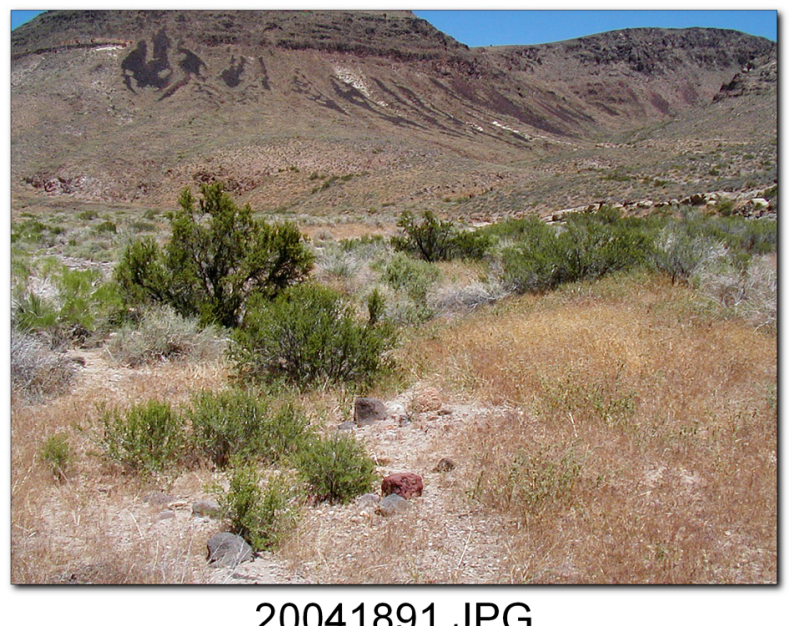

20041891.JPG

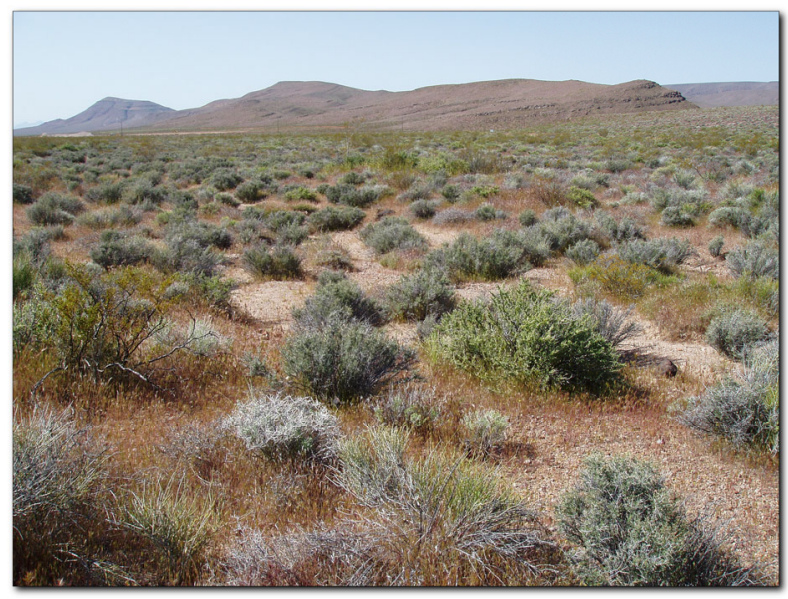

20050561.JPG

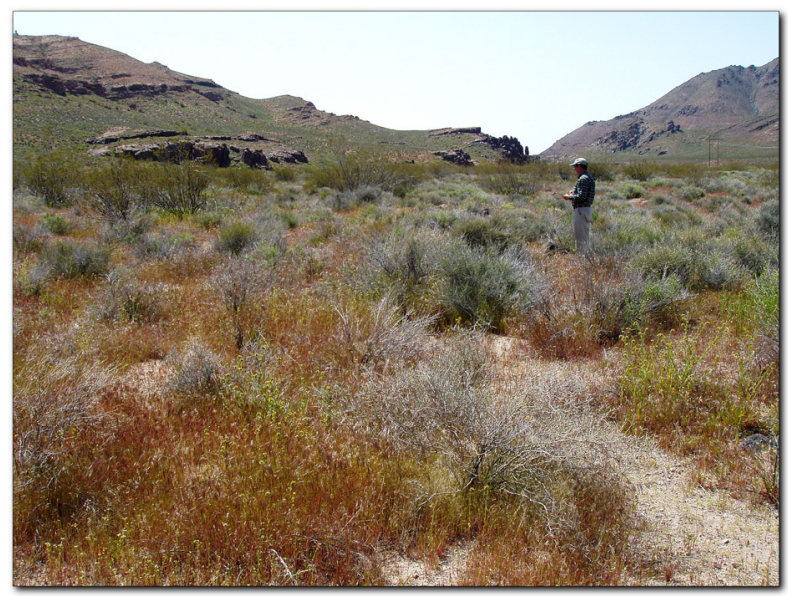

20050631.JPG
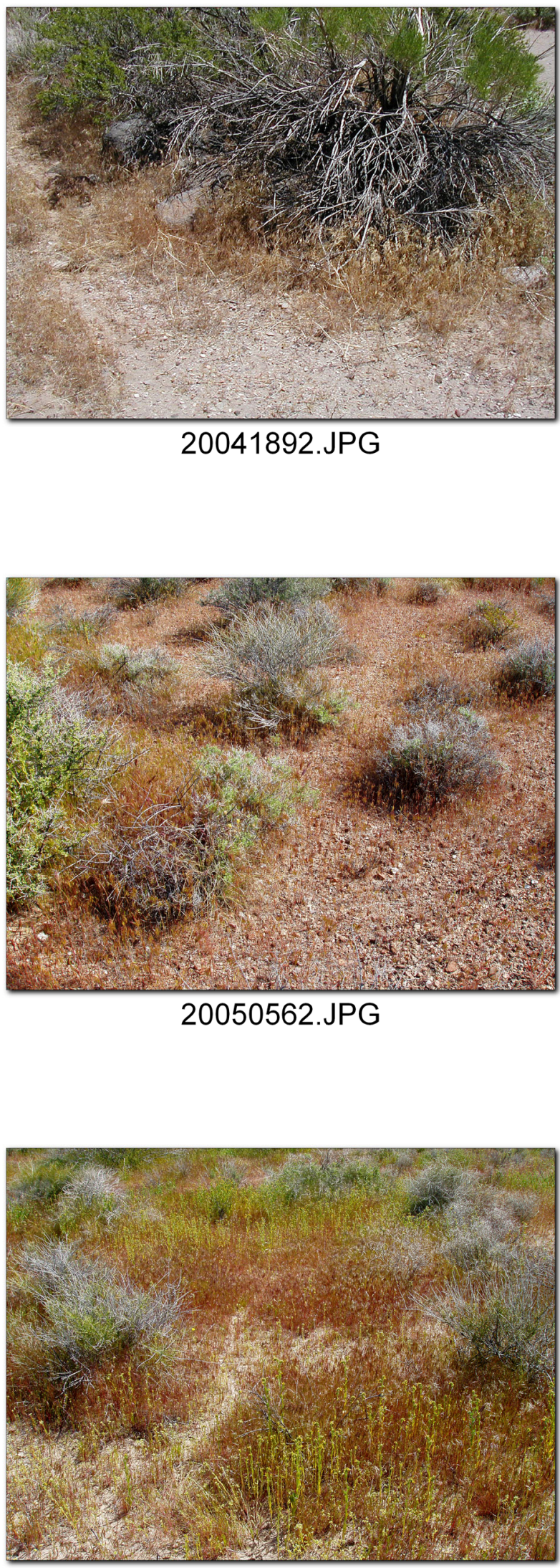

20050632.JPG 
Wildland Fire Fine Fuels Index $=5$

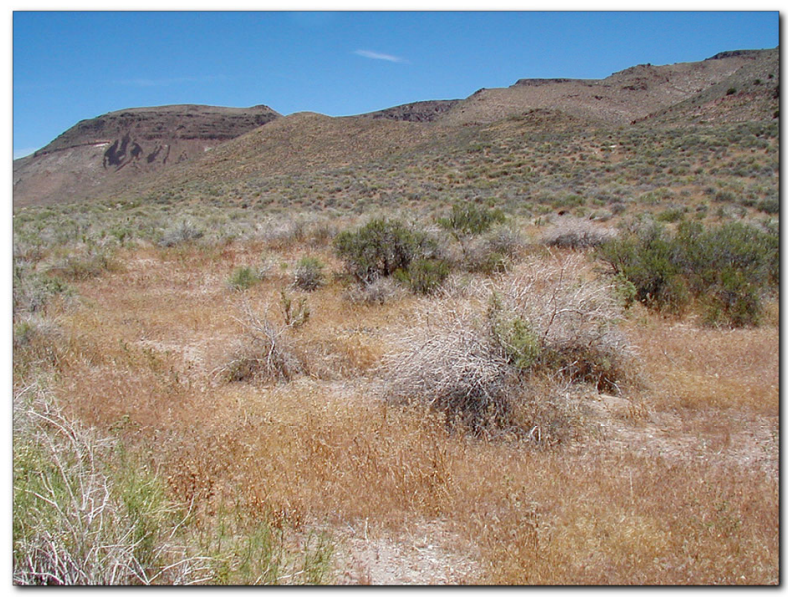

20041901.JPG

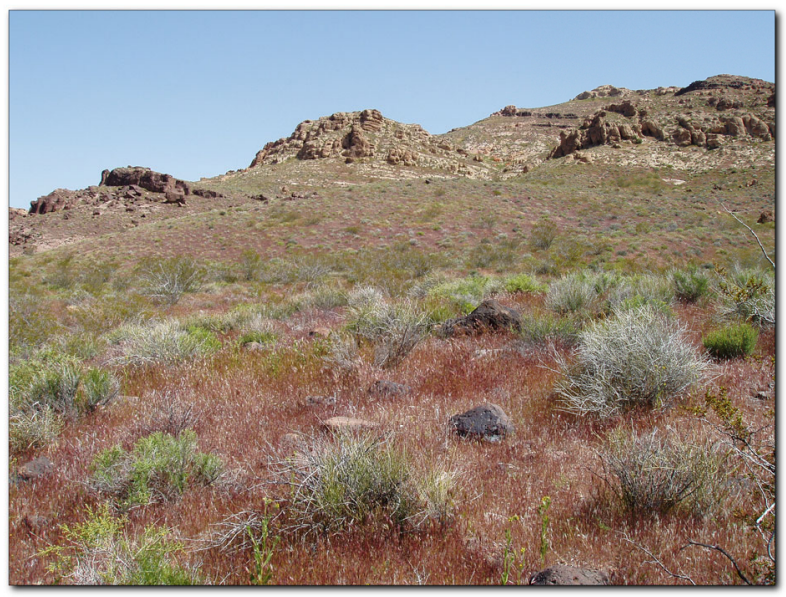

20050621.JPG

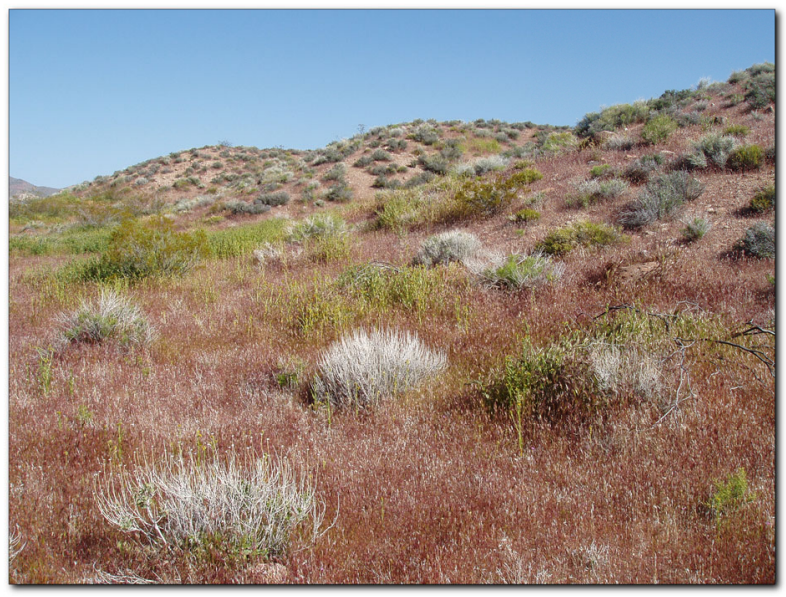

20050711.JPG

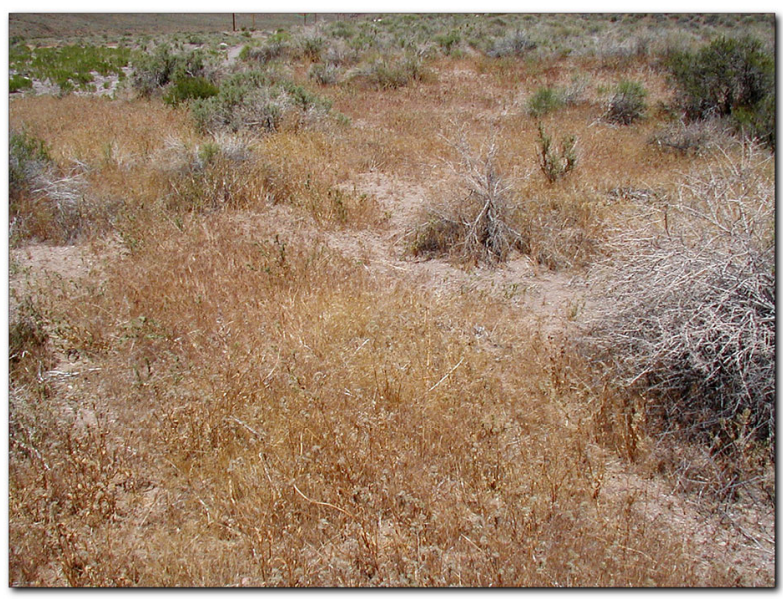

20041902.JPG
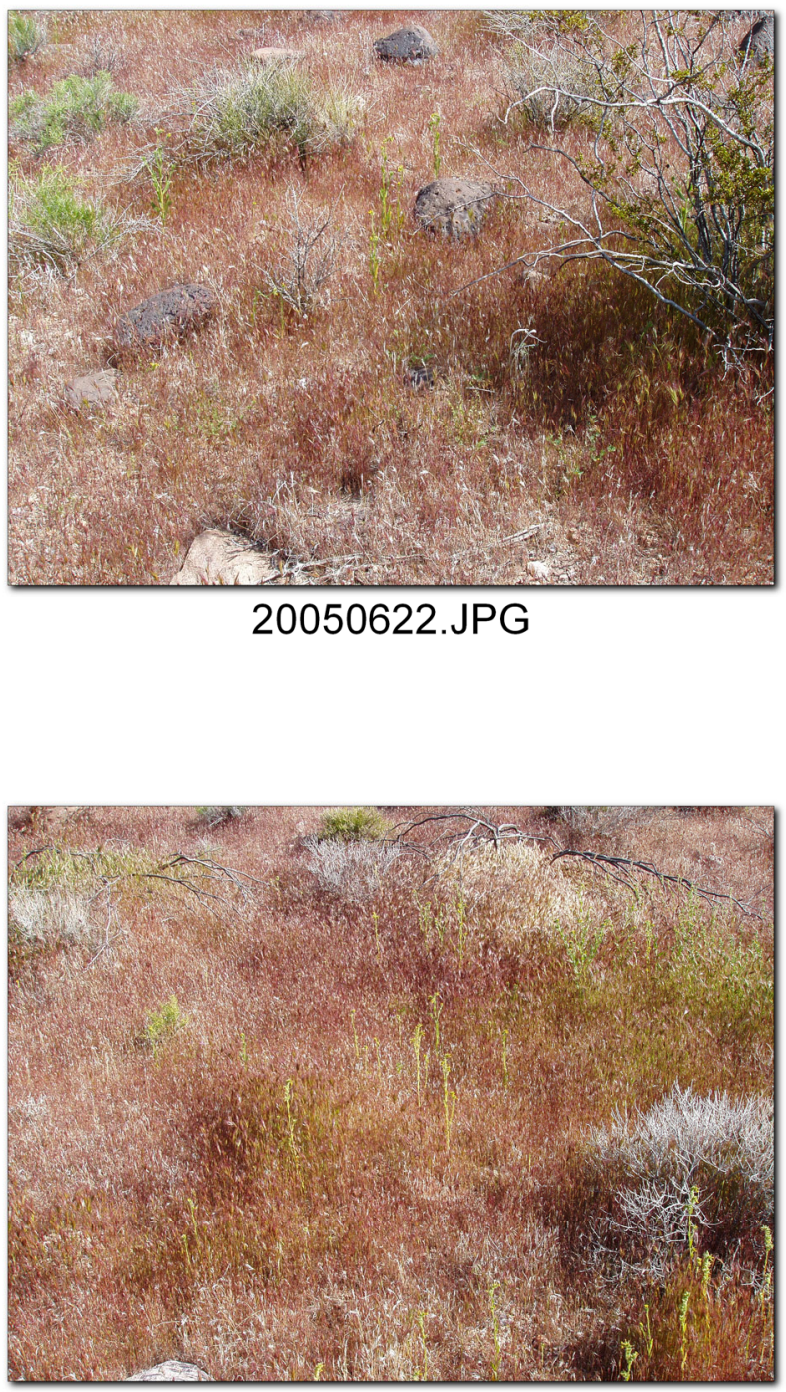

20050712.JPG 
THIS PAGE IS INTENTIONALLY LEFT BLANK 


\section{Appendix B - Historic Records of Wildland Fires on the NTS Obtained During 2005}

This appendix contains new records obtained by extracting information from the NTS Fire Marshal's Log of wildland fires. These records document information obtained during 2005. Spelling, grammar, and other manners of expression reflect the content of the historical log. There has been only a limited attempt to correct or interpret these notes. It is anticipated that additional records for the remaining years will be obtained during 2006. 


\section{Appendix B. NTS Historic Fires}

\begin{tabular}{|c|c|c|c|c|}
\hline Date & Acres & Area & Cause & Description \\
\hline $7 / 23 / 1978$ & 180.0 & 29 & Lightning & $\begin{array}{l}\text { Mine Mtn. Rd., } 81 / 2 \text { miles W. Typah Hwy (Tippipah } \\
\text { Highway?) }\end{array}$ \\
\hline $7 / 23 / 1978$ & 0.1 & 6 & Lightning & $\begin{array}{l}\text { 1/4 mi. W. Typhny \& Merckay Hwy intersection } \\
\text { (Tippipah and Mercury Highway?) }\end{array}$ \\
\hline 8/10/1978 & $1,300.0$ & 25 & Lightning & $4 \mathrm{mi}$. W. (ETS1) \\
\hline $8 / 10 / 1978$ & 0.1 & 12 & Lightning & 4 mi S.E. Area 12 Camp \\
\hline $8 / 10 / 1978$ & 20.0 & 14 & Lightning & S. end of Mid Valley \\
\hline $8 / 12 / 1978$ & 0.1 & 18 & Lightning & W. of Well 8 \\
\hline $8 / 25 / 1978$ & $6,400.0$ & 18 & Smoke bomb & Buckboard Mesa \\
\hline 9/1/1978 & 0.1 & 12 & Smoke bomb & Near Twin Peaks \\
\hline 9/27/1978 & 0.1 & 23 & Gas grenade & WSI Target Range by Water Tank \\
\hline 10/13/1978 & 0.1 & 23 & Gas grenade & Mercury Target Range (by Water Tank?) \\
\hline $6 / 11 / 1979$ & 0.1 & 20 & Unknown & N.W. of U20P (A20) \\
\hline $6 / 13 / 1979$ & 0.1 & 2 & Unknown & 1 mi. S. of (Area) 2 Camp \\
\hline $7 / 16 / 1979$ & 0.1 & & Smoker & Ranier Mesa 1,000 feet north of BJY Intersection \\
\hline $7 / 18 / 1979$ & 0.1 & & Lightning & $\begin{array}{l}\text { Near N. Portal Trailer Park on Mesa Top (Acres }=1 \\
\text { Tree?) }\end{array}$ \\
\hline $8 / 5 / 1979$ & 0.1 & 5 & Lightning & 2 mi. N.W. of Gate 200 \\
\hline $11 / 8 / 1979$ & 0.1 & 6 & Unknown & Sewage lagoon \\
\hline $6 / 30 / 1980$ & 0.1 & 6 & Smoker & $\begin{array}{l}\text { Typ \& M Hwy intersection (Tippipah and Mercury } \\
\text { Highway?) }\end{array}$ \\
\hline 7/1/1980 & 0.1 & 12 & Lightning & $1 \mathrm{mi} . \operatorname{pas}(\mathrm{t}) 12-10 \mathrm{C}$ barricade $($ Acres $=1$ Tree? $)$ \\
\hline $7 / 23 / 1980$ & 0.1 & 12 & Lightning & S. of Camp 12 \\
\hline $7 / 23 / 1980$ & 0.1 & 12 & Lightning & 3 mi. S. of Camp (12?) \\
\hline $7 / 23 / 1980$ & 0.1 & 25 & Lightning & 1 mi. E. RMAD \\
\hline $7 / 23 / 1980$ & 0.1 & 6 & Lightning & E. Bldg. CP150 \\
\hline $7 / 23 / 1980$ & 0.1 & 17 & Lightning & 1/2 mi E. of Camp (17) \\
\hline $7 / 23 / 1980$ & 0.1 & 5 & Lightning & Area 5. \\
\hline $7 / 24 / 1980$ & 0.1 & 25 & Lightning & 2-3 mi NW of EMAD, Small \\
\hline $7 / 24 / 1980$ & 0.1 & & Lightning & Timber Mtn. 5-7 miles off NTS, Small \\
\hline $7 / 24 / 1980$ & 0.1 & & Lightning & Rainer Mesa, N. Tunnel (Above?) pad \\
\hline $7 / 24 / 1980$ & 0.1 & 18 & Unknown & Near Cat Canyon, Size = Small \\
\hline $7 / 25 / 1980$ & 2.0 & 15 & Lightning & 3 mi. N.E. of Security $12-10 \mathrm{C}$, Quarzite Ridge \\
\hline $7 / 30 / 1980$ & $3,500.0$ & 29 & Lightning & Shoshone Mtn. \\
\hline $7 / 30 / 1980$ & $10,000.0$ & 14 & Lightning & MidValley (cause $=$ lightning, guess) \\
\hline $8 / 1 / 1980$ & 0.1 & 19 & Lightning & 2 mi E. Echo Peak \\
\hline $8 / 1 / 1980$ & 0.1 & 17 & Unknown & 1 mi. N.W. of Area 17 Camp \\
\hline $8 / 25 / 1980$ & 0.1 & 15 & Lightning & Near Well 8 \\
\hline 9/7/1980 & 0.1 & 23 & Lightning & 4 mi. W. Mercury on JAF Rd (Jackass Flats Road) \\
\hline 9/7/1980 & 0.1 & 23 & Lightning & 1/2 mi. S.W. Bldg. 650 \\
\hline $9 / 10 / 1980$ & 0.1 & 15 & Lightning & 1 1/2 mi. N.W. Climax Mine \\
\hline 9/13/1980 & 0.1 & 15 & Lightning & 1 mi. W. Climax Mine \\
\hline 9/19/1980 & 0.1 & 9 & Unknown & Near Circle Rd. and 9-01 Rd. (2 fires) \\
\hline $10 / 3 / 1980$ & 0.1 & 3 & Unknown & A3 Subdock (text truncated) pad \\
\hline 10/10/1980 & 0.1 & 30 & Unknown & Cat Canyon \\
\hline $12 / 4 / 1980$ & 0.1 & 23 & Flares & Area 23 (gun?) range \\
\hline $4 / 29 / 1981$ & 0.1 & 25 & Smoker & 1/8 mi. E. Test Cell A \\
\hline $7 / 13 / 1981$ & 0.1 & 30 & AT Flares & 6 mi. W. of Buckboard Mesa Rd. on Timber Mtn. \\
\hline $8 / 11 / 1981$ & 3.0 & 12 & Smoker & $\begin{array}{l}\text { Typ Hwy and Rainer Mesa Rd. (Tippipah Highway } \\
\text { and Rainer Mesa Road?) }\end{array}$ \\
\hline 8/12/1981 & 0.1 & & Lightning & AT Rainer Mesa, 1 Tree \\
\hline
\end{tabular}




\section{Appendix B. NTS Historic Fires}

\begin{tabular}{|c|c|c|c|c|}
\hline Date & Acres & Area & Cause & Description \\
\hline $8 / 15 / 1981$ & 0.1 & 22 & Lightning & A22 Army Well \\
\hline $8 / 17 / 1981$ & 3.0 & 29 & Lightning & A-29 N.E. Section Shoshone Mtn. \\
\hline $8 / 18 / 1981$ & 0.1 & 19 & Lightning & $\begin{array}{l}\text { Pahute Mesa Rd \& D.H. Flats Rd. (Pahute Mesa } \\
\text { Road and Dead Horse Flats Road?) }\end{array}$ \\
\hline 8/18/1981 & 0.1 & 14 & Lightning & A6 Road and Mine Mtn. \\
\hline $8 / 18 / 1981$ & 0.1 & 6 & Lightning & CP 10 \\
\hline $8 / 20 / 1981$ & 0.1 & 19 & Lightning & Area 19,19 AM \\
\hline $8 / 26 / 1981$ & 0.1 & 2 & Lightning & 1 mi. W. of Tippipah Hwy 4 mi. S. A12 Camp \\
\hline 9/13/1981 & 0.1 & 20 & Lightning & U20AJ \\
\hline $6 / 17 / 1982$ & 0.1 & 12 & Lightning & Rainer Mesa above N. Portal \\
\hline $6 / 18 / 1982$ & 0.1 & 12 & Welder & Near Bldg. 12-16 \\
\hline $8 / 12 / 1982$ & 0.1 & 3 & Lightning & 1/2 mi. E. of O.J Blossom Rd. (Orange) \\
\hline $8 / 20 / 1982$ & 0.1 & 6 & Lightning & 100 feet E CP 400,1 Yucca \\
\hline $8 / 27 / 1982$ & 0.1 & 20 & Lightning & U20 AJ \\
\hline $8 / 27 / 1982$ & 0.1 & 20 & Lightning & Substation $20-7$ \\
\hline 6/7/1983 & 0.1 & 8 & Lightning & 1/4 mi. N. Sedan Access Road \\
\hline 6/7/1983 & 0.1 & 11 & Lightning & Tech Facility \\
\hline $6 / 16 / 1983$ & 0.1 & 14 & Truck on brush & 1/2 mi. N. AF Bunker \\
\hline $6 / 19 / 1983$ & 15.0 & 12 & Lightning & Along G Tunnel Portal \\
\hline $6 / 20 / 1981$ & 0.1 & 12 & Hot spots & G Tunnel Portal \\
\hline $6 / 27 / 1983$ & 0.1 & 11 & WSI Training & Tweezer and O.J. Blossom Rd. \\
\hline $6 / 28 / 1983$ & 0.1 & 25 & WSI Training & Cane Spring Road, 2 mi. E. of Bren Tower \\
\hline $7 / 14 / 1983$ & $2,000.0$ & 25 & Truck Exhaust & $\begin{array}{l}\text { Hidden Valley to Buckboard Mesa Road (7-14-83 to } \\
7-17-83)\end{array}$ \\
\hline 7/15/1983 & $2,000.0$ & 16 & Truck Exhaust & Hidden Valley to Buckboard Mesa Road \\
\hline $7 / 16 / 1983$ & $7,000.0$ & 29 & Truck Exhaust & Hidden Valley to Buckboard Mesa Road \\
\hline $7 / 17 / 1983$ & $7,000.0$ & 30 & Truck Exhaust & Hidden Valley to Buckboard Mesa Road \\
\hline $7 / 20 / 1983$ & 25.0 & 15 & Exercise & A15 \\
\hline $7 / 27 / 1983$ & 0.1 & 12 & Cable short & G Tunnel Portal \\
\hline $7 / 27 / 1983$ & 250.0 & 17 & Vehicle exhaust & Sugar Loaf \& Red Rock Valley, N. of Road \\
\hline 8/5/1983 & 0.1 & 12 & Vehicle exhaust & Kawich Valley and Gold Meadows Road \\
\hline $8 / 6 / 1983$ & 0.1 & 15 & Lightning & West of EPA Farm \\
\hline 8/9/1983 & 0.1 & 3 & Lightning & O.J. Blossom Road and Rd 6-09 Intersection \\
\hline $8 / 15 / 1983$ & 0.1 & 23 & Lightning & Near Gate 200 \\
\hline $11 / 15 / 1983$ & 0.1 & 12 & Lightning & Tunnel Portal Area \\
\hline $3 / 26 / 1984$ & 0.1 & 23 & Exercise Tracers & 1000 yards $\mathrm{N}$. of firing range \\
\hline $5 / 8 / 1984$ & 200.0 & 25 & Unknown & Yucca Mountain \\
\hline $5 / 31 / 1984$ & 400.0 & 14 & Lightning & Mid Valley \\
\hline $6 / 13 / 1984$ & & & Unknown & Big? At Toluchie Peak N/U20AL \\
\hline $6 / 14 / 1984$ & 0.1 & 11 & Lightning & 1 Yucca \\
\hline $6 / 14 / 1984$ & 0.1 & 12 & Lightning & 1 Yucca; N Tunnel Access Road \\
\hline $6 / 15 / 1984$ & 0.1 & 15 & Lightning & 2 mi NW. of $8-1-C$ barricade \\
\hline $6 / 21 / 1984$ & 300.0 & 19 & AF Smoke bomb & (AF=Air Force?), Dead Horse Flats Rd. \\
\hline $7 / 2 / 1984$ & 0.1 & 17 & Lightning & N. of Well 8 Road \\
\hline $7 / 2 / 1984$ & 200.0 & 18 & Lightning & Near Timber Mtn. \\
\hline $7 / 2 / 1984$ & 0.1 & 23 & Lightning & E. Gate $100 ; 5$ fires $<1$ acre \\
\hline $7 / 3 / 1984$ & 5.0 & 19 & Lightning & 2 mi. N. of 17 Camp \\
\hline $7 / 3 / 1984$ & 6.0 & 15 & Unknown & N. \& E. of Culman Mine \\
\hline $7 / 6 / 1984$ & 5.0 & 29 & Unknown & (No comment was provided in the log) \\
\hline $7 / 12 / 1984$ & 0.1 & 12 & Lightning & S.E. of G Tunnel \\
\hline
\end{tabular}




\section{Appendix B. NTS Historic Fires}

\begin{tabular}{|c|c|c|c|c|}
\hline Date & Acres & Area & Cause & Description \\
\hline 8/3/1984 & 15.0 & 30 & Unknown & $\begin{array}{l}1 \text { mi. S. of Buckboard Mesa \& } 40 \text { Mile Canyon } \\
\text { Junction }\end{array}$ \\
\hline $8 / 9 / 1984$ & 0.1 & 19 & Lightning & $1 \mathrm{mi} . \mathrm{W}$ of $\mathrm{A} 19 \mathrm{Well}$ \\
\hline $8 / 11 / 1984$ & 0.1 & 18 & Lightning & 1 mi. N. of Airport Rd. \\
\hline $4 / 26 / 1985$ & 0.1 & 17 & Smoking & N. of Camp 17 \\
\hline 6/4/1985 & 0.1 & 12 & Lightning & S.E. of Camp \& Tunnel Rd. \\
\hline $6 / 18 / 1985$ & 0.1 & 18 & Lightning & Pahute Mesa \& Stockade Wash Rd. \\
\hline $6 / 18 / 1985$ & 3.0 & 12 & Lightning & Gold Meadows \\
\hline 6/24/1985 & $1,500.0$ & 30 & Lightning & (No comment was provided in the log) \\
\hline $6 / 24 / 1985$ & 0.1 & 17 & Lightning & 1 Tree \\
\hline 6/24/1985 & 100.0 & 6 & Lightning & Mine Mountain Road and Tippipah Highway \\
\hline 6/24/1985 & 0.1 & 17 & Lightning & N. of Well 8 \\
\hline $6 / 26 / 1985$ & 5.0 & 19 & Smoking & smoke of lighy (smoking or lightning?) \\
\hline $6 / 27 / 1985$ & 0.1 & 27 & WSI Pot Bomb & (No comment was provided in the log) \\
\hline $8 / 25 / 1985$ & 0.1 & 5 & Smoking & $1 / 2$ mi. N. Gate 200 \\
\hline $5 / 5 / 1986$ & 0.1 & 12 & Smoking & N. Tunnel Portal \\
\hline $5 / 19 / 1986$ & 60.0 & 14 & Rocket Test & Rocket Motor Area \\
\hline $5 / 31 / 1986$ & 15.0 & 20 & $\begin{array}{l}\text { Accident, truck } \\
\text { rollover }\end{array}$ & 3 mi. S. Rainer Mesa Rd on Buckboard Mesa Rd \\
\hline $6 / 13 / 1986$ & 0.1 & 30 & Unknown & Lightning? N.E. and 40 Mile Canyon \\
\hline $7 / 21 / 1986$ & $1,600.0$ & 14 & Unknown & Mid Valley Rad E. Shoshone Mtn \\
\hline 7/21/1986 & 0.1 & 19 & Lightning & (No comment was provided in the log) \\
\hline 7/21/1986 & 0.1 & 6 & Lightning & 1 Yucca; W. of gas station \\
\hline $7 / 24 / 1986$ & 0.1 & 5 & Lightning & 1 Yucca, 1 mi. N. of Gate 200 \\
\hline $7 / 24 / 1986$ & 0.1 & 5 & Lightning & 1 Yucca, $1 / 2$ mi. N. of Gate 200 \\
\hline $7 / 24 / 1986$ & 0.1 & 26 & Lightning & N.W. side of Yucca Mountain \\
\hline $8 / 11 / 1986$ & 0.1 & 18 & Unknown & 3 Trees \\
\hline $8 / 25 / 1986$ & 0.1 & 19 & Lightning & Buckboard Mesa \\
\hline $4 / 21 / 1987$ & 0.1 & 17 & Unknown & $\begin{array}{l}\text { Pahute Mesa Road; } 1 \text { miles North of of Area } 16 \\
\text { Hill; small area of smoldering vegetation } 20 \text { feet } x \\
10 \text { feet. }\end{array}$ \\
\hline $4 / 27 / 1987$ & 0.1 & 12 & Lightning & $\begin{array}{l}\text { A-12, S.W. off "N" Tunnel Road, (brush fire); one } \\
\text { juniper tree burned and aroud about } 5 \text { to } 6 \text { feet } \\
\text { around tree }\end{array}$ \\
\hline $5 / 12 / 1987$ & 0.1 & 25 & Lightning & $\begin{array}{l}\text { Area } 25 \text { Road, past sewer ponds, } 1 \text { burned yucca } \\
\text { plant W. of Sanitation Ponds }\end{array}$ \\
\hline $5 / 30 / 1987$ & 0.1 & 22 & Lightning & Army Well 1, Pole \\
\hline $6 / 8 / 1987$ & 0.1 & 1 & Lightning & $\begin{array}{l}\text { East of Tippipah Hwy at mile marker \#31 in Area } 1 \\
\text { near Mine Mtn. Road; } 15 \mathrm{sq} \mathrm{ft} \mathrm{grass} \mathrm{and} \mathrm{brush}\end{array}$ \\
\hline 6/9/1987 & 0.1 & 19 & Lightning & $\begin{array}{l}\text { U19AR, brush fire; one pi ne tree smoldering. } 50 \text { sq. } \\
\mathrm{ft} \text {. }\end{array}$ \\
\hline $6 / 28 / 1987$ & 200.0 & 25 & Lightning & 3 mi. N.E. of TCC (Test Cell C?) \\
\hline $7 / 15 / 1987$ & 0.1 & 25 & Smoke Grenade & $\begin{array}{l}\text { Top of Skull Mt on S.E. side; smoke grenade used } \\
\text { to show location of site for helicopter to drop off } \\
\text { equipment. Sparks started brush fire. } 40 \text { sq. yds. }\end{array}$ \\
\hline 8/3/1987 & 0.1 & 6 & Lightning & 1 yucca, 2 mi. S. of CP, N.W. of Hi-way. \\
\hline 8/5/1987 & 0.1 & 4 & Welding & $\begin{array}{l}\text { Welding of aboveground water supply pipe, } 1 / 4 \text { mile } \\
\text { W. of Rainer Mesa Road and } 1 / 4 \text { mile south of Area } \\
2 \text {, area } 10 \text { ' by } 100 \text { ' long. }\end{array}$ \\
\hline 9/1/1987 & 0.1 & 17 & Lightning & W. of Camp 17 \\
\hline 9/1/1987 & 0.1 & 19 & Lightning & $19 \mathrm{P}$ \\
\hline
\end{tabular}




\section{Appendix B. NTS Historic Fires}

\begin{tabular}{|c|c|c|c|c|}
\hline Date & Acres & Area & Cause & $\begin{array}{l}\text { Description } \\
\end{array}$ \\
\hline 9/1/1987 & 0.1 & 20 & Lightning & $\begin{array}{l}\text { U20 AR, } 15^{\prime} \times 15^{\prime} \text { area, one tree was on fire, } \\
\text { extinguished by rain. }\end{array}$ \\
\hline 9/1/1987 & 0.1 & 20 & Unknown & West of U20K, brush fire (self extinguished) \\
\hline $6 / 5 / 1987$ & 0.1 & 19 & Lightning & $\begin{array}{l}\text { Approximate } 200 \text { yards from GZ at U19AR, (couldn't } \\
\text { find burn, apparently extinguished itself). }\end{array}$ \\
\hline $7 / 23 / 1987$ & 0.1 & 18 & Asphalt & $\begin{array}{l}1 \text { hot plant from asphalting the road. } 12 \text { miles out } \\
\text { Buckboard Mesa Road near area } 18 \text { Airport Rd. }\end{array}$ \\
\hline 8/3/1987 & 0.1 & 4 & Lightning & $\begin{array}{l}\text { Approximately } 4 \text { miles N. of Pahute Mesa and } \\
\text { Stockade Wash Rd. Large cedar tree was burning }\end{array}$ \\
\hline 8/3/1987 & 0.1 & 18 & Lightning & Area \#18 Guard Station \#400, small vegetation fire. \\
\hline 9/24/1987 & 0.1 & 19 & Lightning & $\begin{array}{l}\text { A-19 Between } U-19-A Q \text { and Echo Peak, } 2 \text { mile hike } \\
\text { into the fir through steep canyon, four large trees } \\
\text { and brush around the trees. Area was } 30^{\prime} X 30^{\prime} \text {. }\end{array}$ \\
\hline 9/24/1987 & 0.1 & 19 & Lightning & $\begin{array}{l}\text { Area } 19 \text { approximately } 2.5 \text { miles east of U19AQ. } \\
\text { Smoke on tree trunk. }\end{array}$ \\
\hline $10 / 13 / 1987$ & 0.1 & 5 & Lightning & 1 power line pole burned, 6 damaged by storm. \\
\hline $4 / 21 / 1988$ & 0.1 & 5 & Lightning & $\begin{array}{l}1 \text { power line pole burned, extinguished with } 100 \\
\text { gallons of water, Area \#5, Mercury Hwy, } 1 / 2 \text { mile } \\
\text { north of telephone. }\end{array}$ \\
\hline $6 / 27 / 1988$ & 0.1 & 17 & Lightning & 1 tree was on fire, no other vegetation was involved. \\
\hline $6 / 23 / 1988$ & 0.1 & 25 & Lightning & $\begin{array}{l}\text { BLM assisted to extinguish fire; west of Fortymile } \\
\text { Canyon in Area } 25,29 \text { (area of fire unkwn, but } \\
\text { required many firefighters). }\end{array}$ \\
\hline $6 / 22 / 1988$ & 0.1 & 19 & Lightning & Near Hole Site U19AX, extinguished by rain. \\
\hline $6 / 22 / 1988$ & 0.1 & 25 & Lightning & $\begin{array}{l}\text { Area } 25 \text { in Fortymile Canyon. Winds burning on } \\
\text { south side, nothing but spot fires on north rim (Area } \\
\text { of fire ukwn, but burned through night with winds } \\
\text { and extinguished the next day). }\end{array}$ \\
\hline $6 / 17 / 1988$ & 0.1 & 6 & Lightning & $\begin{array}{l}\text { Approximately three miles south of Control Point, } \\
1 / 2 \text { mile east of Mercury Hwy., One yucca plant ( } 15 \\
\text { ft) plus } 30 \text { sq. ft. of ground vegetation. }\end{array}$ \\
\hline $7 / 31 / 1988$ & 0.1 & 19 & Lightning & $\begin{array}{l}\text { At Picture Rock, Approximately } 3 \text { miles S.W. of } \\
\text { Echo Peak, on highest peak in area (fire was small). }\end{array}$ \\
\hline $7 / 31 / 1988$ & 0.1 & 22 & Lightning & $\begin{array}{l}\text { One-half mile west on Jackass Flat Highway } \\
\text { northwest of Bulk Fuel Station, extinguished by rain. }\end{array}$ \\
\hline $7 / 29 / 1988$ & 3.0 & 6 & Lightning & $\begin{array}{l}\text { One mile west of Pahute Mesa Road - N. Side of 6- } \\
04 \text { Road. }\end{array}$ \\
\hline $7 / 29 / 1988$ & 0.1 & 16 & Lightning & $\begin{array}{l}4 \text { miles south west of } A-16 \text { Airport. } 100 \times 200 \text { yards } \\
\text { of fire burning, extinghished by rain. }\end{array}$ \\
\hline $7 / 29 / 1988$ & 250.0 & 15 & Lightning & Area \#15, Oak Spring Area (Twin Peak Area). \\
\hline $7 / 26 / 1988$ & 0.1 & 20 & Lightning & $\begin{array}{l}\text { New sump area in Area } 20 ; 2 \text { pine trees and a } 20^{\prime} x \\
20^{\prime} \text { area of brush was burned. }\end{array}$ \\
\hline $7 / 21 / 1988$ & 0.1 & 19 & Lightning & $\begin{array}{l}\text { Area } 19 \text {, about } 2 \text { miles west of } U 19 A X \text {, bush or tree } \\
\text { fire in rough terrain. }\end{array}$ \\
\hline $7 / 20 / 1988$ & 150.0 & 12 & Unknown & $\begin{array}{l}\text { Area 12, N Tunnel Road. } 100 \text { ' x } 1500 \text { ' (150 acres) } \\
\text { of brush, pinyon pine and juniper burned. }\end{array}$ \\
\hline
\end{tabular}




\section{Appendix B. NTS Historic Fires}

\begin{tabular}{|c|c|c|c|c|}
\hline Date & Acres & Area & Cause & Description \\
\hline $7 / 20 / 1988$ & 500.0 & 16 & Smoking & $\begin{array}{l}\text { Area } 16 \text { N/W quadrant - } 3 \text { miles west of Shaker } \\
\text { Plant, discarded smoking material was probable } \\
\text { cause (no lightning in area). }\end{array}$ \\
\hline $8 / 26 / 1988$ & 0.1 & 12 & Lightning & $\begin{array}{l}\text { Stockade Wash Rd approximately } 1 \text { mile past } \\
\text { Holmes Rd. } 1 \text { tree and } 20^{\prime} \text { x } 30^{\prime \prime} \text { grassy area burned }\end{array}$ \\
\hline $8 / 25 / 1988$ & 50.0 & 14 & Lightning & $\begin{array}{l}\text { 2,000 ft. north of Shoshone Rd. west side of Middle } \\
\text { (Mid?) Valley. } 50 \text { acres of brush. }\end{array}$ \\
\hline 8/1/1988 & 0.1 & 23 & Lightning & $\begin{array}{l}\text { Cactus fire, extinghished by heavy rain. } 300 \text { yds N. } \\
\text { and E. of W.S.I Pistol Range. }\end{array}$ \\
\hline 8/1/1988 & 0.1 & 6 & Lightning & $\begin{array}{l}\text { One yucca plant } 1 / 2 \text { mile south of D.A.F. Facility in } \\
\text { Area } \# 6,1 / 4 \text { mile west of Mercury Highway, } \\
\text { extinguished by rain. }\end{array}$ \\
\hline 8/1/1988 & 0.1 & 1 & Lightning & $\begin{array}{l}\text { Two miles north of shaker plant on Tippipah } \\
\text { Highway (no damage reported, raining at the time). }\end{array}$ \\
\hline 8/1/1988 & 0.1 & 12 & Lightning & $\begin{array}{l}\text { G Tunnel, burned about } 50 \times 50 \text { yards of brush, } \\
\text { extinguished by shovels. }\end{array}$ \\
\hline 9/27/1988 & 0.1 & 23 & Smoke Grenade & $\begin{array}{l}50 \text { feet S.W. of Shooting Range. About } 10 \text { sq. } \mathrm{ft} \\
\text { straight line of grass was burned. }\end{array}$ \\
\hline $11 / 7 / 1988$ & 0.1 & 16 & Unknown & $\begin{array}{l}\text { West side Area } 16 \text { Mountain on Pahute Mesa Road. } \\
\text { Smoke reported for wildland brush fire in Area } 16 \text { or } \\
17 \text {, fire extinguished by person reporting it. }\end{array}$ \\
\hline $11 / 4 / 1988$ & 0.1 & 19 & Unknown & $\begin{array}{l}\text { Horseshoe Curve on Area } 19 \text { Hill. } 10^{\prime} \times 100^{\prime} \text { area } \\
\text { and } 20^{\prime} \times 30^{\prime} \text { of bushes burned. Fire extinguished by } \\
\text { DRI personnel. }\end{array}$ \\
\hline $12 / 10 / 1988$ & 0.1 & 12 & Rock Spark & $\begin{array}{l}\text { Probable cause was sparks from rock slide in } \\
\text { excessively dry area of brush. 50' x } 75^{\prime} \text { area of } \\
\text { brush and trees turned. }\end{array}$ \\
\hline $1 / 18 / 1989$ & 0.1 & 12 & Smoking & $\begin{array}{l}\text { Left side of T-Tunnel Access Road, just a small } \\
\text { burned bush. }\end{array}$ \\
\hline 3/29/1989 & 0.1 & 12 & Smoking & $\begin{array}{l}\text { Rainier Mesa Rd, } 1.5 \text { miles north of "G" Tunnel Rd., } \\
\text { bush fire was small in size, probably caused by } \\
\text { careless dispoal of smoking material. }\end{array}$ \\
\hline 3/25/1989 & 0.1 & 22 & Unknown & $\begin{array}{l}\text { State Highway } 951 / 2 \text { mile west of Mercury } \\
\text { Interchange; possibly weekend protesters, }\end{array}$ \\
\hline 3/13/1989 & 0.1 & 23 & Vehicle Exhaust & $\begin{array}{l}1 / 4 \text { mile north of Core Library Building } 12-830 \text {, } \\
\text { burned bush and area } 20^{\prime} X 20^{\prime} \text {. Caused by catalytic } \\
\text { converter which was red hot and engine backfire. }\end{array}$ \\
\hline 4/27/1989 & 0.1 & 3 & Lightning & $\begin{array}{l}\text { Located at U3FD crater rim area } 4^{\prime} \times 60^{\prime} \text { burned. 1/2 } \\
\text { mile S. of Area \# } 3 \text { Camp. }\end{array}$ \\
\hline 4/11/1989 & 0.1 & 22 & Sparklers & $\begin{array}{l}\text { Protesters started with sparklers or flares, small } \\
\text { Yucca (YUSH) was burned, (photos in report). }\end{array}$ \\
\hline 5/6/1989 & 0.1 & 6 & Broken Powerline & $\begin{array}{l}\text { About } 2.5 \text { miles south of Station \#6 on Mercury } \\
\text { Highway, area about } 50^{\prime} \times 3 \text { ' of vegetation. Caused } \\
\text { by broken powerline falling on bush and setting it on } \\
\text { fire. }\end{array}$ \\
\hline
\end{tabular}




\section{Appendix B. NTS Historic Fires}

\begin{tabular}{|c|c|c|c|c|}
\hline Date & Acres & Area & Cause & Description \\
\hline $6 / 22 / 1989$ & 110.0 & 20 & Rock Spark & $\begin{array}{l}\text { Approximately } 3 \text { miles N. of U20 AY, about } 110 \\
\text { acres, extended to Nellis Range, BLM assisted. } \\
\text { Probable cause was spark from rock slide caused } \\
\text { by ground motion from test activity. }\end{array}$ \\
\hline $6 / 12 / 1989$ & 0.1 & 19 & Smoking & $\begin{array}{l}0.5 \text { miles south of "Horse Shoe Curve " in Area } 19 \\
\text { on west edge of Pahute Mesa Rd. Possible } \\
\text { cigarette butt from vehicle or possibly a spark from } \\
\text { an exhaust syste on heavy equipment. 30' x 6' size } \\
\text { area of shrubs and trees. }\end{array}$ \\
\hline 6/7/1989 & 200.0 & 25 & Lightning & $\begin{array}{l}\text { Area } 25 \text {, about } 3 / 4 \text { mile across burning. Yucca } \\
\text { Mountain area. }\end{array}$ \\
\hline 7/7/1989 & 0.1 & 19 & Smoking & $\begin{array}{l}\text { Brush fire near Well 19C, possible cigarette, burned } \\
\text { appromatem } 100^{\prime} \text { x 50' of brush. }\end{array}$ \\
\hline $8 / 11 / 1989$ & 0.1 & 23 & Lightning & $\begin{array}{l}1 \text { mile west of Mercury A-23, } 1 \text { clump of } 5 \text { cacti } \\
\text { (yuccas?) }\end{array}$ \\
\hline 8/8/1989 & 1.0 & 19 & Lightning & $\begin{array}{l}\text { Approximately } 1 \text { acres of trees and brush burned. } \\
\text { Location several miles west of U19BA. }\end{array}$ \\
\hline 9/19/1989 & 0.1 & 5 & Unknown & $\begin{array}{l}\text { Brush fire at Hill Top in Area } 5 \text { (specifics } \\
\text { unreported). }\end{array}$ \\
\hline $11 / 20 / 1989$ & 0.1 & 23 & Smoking & $\begin{array}{l}\text { Mercury Hwy - } 200 \text { Hill near Guard Gate, brush fire } \\
\text { about } 20^{\prime} \text { x 30' in area. }\end{array}$ \\
\hline $8 / 14 / 1990$ & 0.1 & 19 & Lightning & $\begin{array}{l}\text { West of Echo Peak near the highway. Extinguished } \\
\text { by rain. }\end{array}$ \\
\hline 8/9/1990 & 0.1 & 12 & Lightning & $\begin{array}{l}\text { Area 12, approximately } 1 / 2 \text { mile from Holmes Road } \\
\text { South of Stockade Wash Road. } 10^{\prime} \times 20^{\prime} \text { area of } \\
\text { brush and about } 6 \text { trees. }\end{array}$ \\
\hline 8/9/1990 & 0.1 & 23 & Lightning & $\begin{array}{l}\text { Area 23, About } 2 \text { miles east of Mercury. Cactus } \\
\text { (yucca?) smoldering. }\end{array}$ \\
\hline 8/8/1990 & 0.1 & 19 & Lightning & $\begin{array}{l}\text { Area } 19,3 \text { miles south of the Dead Horse Flats } \\
\text { Road. Area about } 50^{\prime} \times 50^{\prime} \text { and } 3 \text { threes were } \\
\text { burned. }\end{array}$ \\
\hline 8/4/1990 & 0.1 & 12 & Lightning & $\begin{array}{l}\text { Area 12, } 1 / 4 \text { miles south of "E" Tunnel Access } \\
\text { Road. Crew had to hike up steep slope to fire. }\end{array}$ \\
\hline 4/26/1990 & 0.1 & 19 & Lightning & $\begin{array}{l}\text { Vicinity of Picture Rock in Area 19, at intersection of } \\
\text { Pahute Rd and Buckboard Mesa Rd. A small fire. }\end{array}$ \\
\hline 8/4/1990 & 0.1 & 12 & Unknown & $\begin{array}{l}\text { Brush over G Tunnel in Area 12. A couple of trees } \\
\text { burning on top of G Tunnel. }\end{array}$ \\
\hline $7 / 24 / 1991$ & 0.1 & 19 & Smoking & $\begin{array}{l}\text { Area 19, by Horse Shoe Turn on } 19 \text { Hill. A small } \\
\text { grass fire approximately } 50^{\prime} \text { x } 100^{\prime} \text { probable cause } \\
\text { was discared cigarette. }\end{array}$ \\
\hline 8/1/1991 & 0.1 & 6 & Lightning & $\begin{array}{l}\text { Area } 6 \text { - } 60 \text { H Rad, West Side Bottom } 311 \text { Hill. } \\
\text { Yucca tree found smoldering. }\end{array}$ \\
\hline $8 / 11 / 1991$ & 0.1 & 22 & Lightning & $\begin{array}{l}1 / 4 \text { mile north of Camp Desert Rock run way. Two } \\
\text { cactus were burning. }\end{array}$ \\
\hline $8 / 11 / 1991$ & 0.1 & 25 & Lightning & NRDS Highway, (Area 25) cactus on fire. \\
\hline 3/11/1992 & 0.1 & 17 & Smoking & $\begin{array}{l}\text { Pahute Mesa Road, about 5-7 miles N. of Shaker } \\
\text { Plant. Possible cigarette thrown from vehicle, brush } \\
\text { burned a spot } 20^{\prime} \text { x } 50^{\prime} \text { in area. }\end{array}$ \\
\hline $5 / 28 / 1992$ & 0.1 & 6 & Lightning & Area $6,60 \mathrm{H}$ Road West, one yucca tree. \\
\hline
\end{tabular}




\section{Appendix B. NTS Historic Fires}

\begin{tabular}{|c|c|c|c|c|}
\hline Date & Acres & Area & Cause & Description \\
\hline 6/2/1992 & 0.1 & 5 & Lightning & $\begin{array}{l}\text { Area 5, 5-01 Road. Two or three Yucca plants } \\
\text { burning. }\end{array}$ \\
\hline 6/2/1992 & 0.1 & 23 & Lightning & $\begin{array}{l}\text { Area 23, } 100 \text { yrds S. and East of Knothole Ave. and } \\
\text { Bldg } 683,1 \text { yucca tree. }\end{array}$ \\
\hline $6 / 18 / 1992$ & 0.1 & 23 & Smoking & $\begin{array}{l}\text { Area 23, Mercury Hwy and By Pass Rd. Cigarette } \\
\text { dropped out car window. } 3^{\prime} \times 4^{\prime} \text { brush and grass fire. }\end{array}$ \\
\hline 7/4/1992 & 150.0 & 19 & Bird Powerline & $\begin{array}{l}\text { Area 19, off dead Horse Flat Road in remote and } \\
\text { rugged terrain, raven landed on powerline and } \\
\text { burned, fell into dry grass and fire spread by } 50 \mathrm{mph} \\
\text { winds to trees }\end{array}$ \\
\hline $8 / 11 / 1992$ & 0.1 & 18 & Lighning & Area 18, Well \#8 Access Road, one bush burning. \\
\hline $8 / 11 / 1992$ & 0.1 & 18 & Rekindle & $\begin{array}{l}\text { Area 18, Well \#8 Access Road, rekindle from } \\
\text { previous day. }\end{array}$ \\
\hline $8 / 14 / 1992$ & 0.1 & 18 & Lightning & South Rainier Mesa and Stockade Wash Roads. \\
\hline $8 / 18 / 1992$ & 80.0 & & Unknown & $\begin{array}{l}\text { Rooster Point on Mesa Top. Approximately } 40 \text { to } \\
80 \text { acres. "Danger Crater Possible" sign at site. }\end{array}$ \\
\hline $8 / 22 / 1992$ & 0.1 & 12 & Unknown & $\begin{array}{l}\text { Rainer Mesa on top of } \mathrm{N} \text { Tunnel, } 2 \text { hot stops, put } \\
\text { out with dirt. }\end{array}$ \\
\hline 10/2/1992 & 0.1 & 12 & Vehicle Exhaust & Dry brush under vehicle. \\
\hline 8/5/1993 & 0.1 & 11 & Lightning & $\begin{array}{l}\text { Area } 11 \text { by Orange Blossom Road, three trees } \\
\text { burned. }\end{array}$ \\
\hline 8/5/1993 & 0.1 & 23 & Lightning & $\begin{array}{l}\text { Area 23, Pole Line Raod by Gate 200. Yucca brush } \\
\text { fire - } 1 \text { scorched yucca. }\end{array}$ \\
\hline 8/5/1993 & 0.1 & 23 & Lightning & $\begin{array}{l}\text { Area } 23 \text {, between running track and Microwave } \\
\text { Bldg. } 1 \text { yucca burned. }\end{array}$ \\
\hline 8/5/1993 & 0.1 & 22 & Ligntning & $\begin{array}{l}\text { Area 22, East of Gate } 100 \text { toward the hills, a couple } \\
\text { of burned bushes. }\end{array}$ \\
\hline 8/16/1993 & 0.1 & 6 & Smoking & $\begin{array}{l}\text { Tweeser Rd off Mercury Hwy. } 10 \text { feet of burned } \\
\text { grass. }\end{array}$ \\
\hline $11 / 3 / 1993$ & 0.1 & 16 & Unknown & Near Tunnel in Area 16 \\
\hline 7/8/1995 & 50.0 & 25 & Lightning & 3 miles east of Bren Tower \\
\hline 8/23/1995 & $4,500.0$ & 29 & Unknown & $\begin{array}{l}\text { Started behind Test Cell C in Area } 25 \text { and moved } \\
\text { into Tonopah Valley. About } 1 \text { mile in length; winds } \\
\text { picked up causing fire to get into the heavy timber } \\
\text { on base of Shoshone Mountain making fire larger } \\
\text { and difficult to fight. Fire retardant and fire breaks } \\
\text { were used. }\end{array}$ \\
\hline 4/12/1995 & 0.1 & 25 & Smoking & $5^{\prime} \times 15^{\prime}$ in brush. \\
\hline $6 / 21 / 1995$ & 0.2 & 22 & Unknown & $\begin{array}{l}\text { Possible smoking, } 1 / 5 \text { acre of brush. } 5 \text { miles east of } \\
\text { Area } 27 \text { turnoff on Jackass Flat road. }\end{array}$ \\
\hline 8/22/1995 & 0.1 & 22 & Lightning & $\begin{array}{l}1 \text { Joshua tree, } 1 / 2 \text { miles south from Gate } 100 \text { on } \\
\text { East side of Mercury Highway. }\end{array}$ \\
\hline 8/29/1995 & 0.1 & 23 & Tracer & $\begin{array}{l}30 \text { ' x } 30 \text { ' brush fire caused by military tracer round } \\
\text { near Area } 23 \text { Able Shooting Range. }\end{array}$ \\
\hline 9/6/1995 & 50.0 & 25 & Unknown & $\begin{array}{l}\text { Reported by about } 40 \text { military personnel, in shrub } \\
\text { land at NTS Grid D-21 and } 22 \text {. }\end{array}$ \\
\hline $10 / 4 / 1995$ & 0.3 & 6 & Unknown & $\begin{array}{l}\text { Small grass fire located } 1 / 2 \text { mile north of CP Hill. } \\
\text { Fire burned right along the roadway. }\end{array}$ \\
\hline
\end{tabular}




\section{Appendix B. NTS Historic Fires}

\begin{tabular}{|c|c|c|c|c|}
\hline Date & Acres & Area & Cause & Description \\
\hline $5 / 28 / 2001$ & 10.0 & 1 & Lightning & $\begin{array}{l}\text { 3/4 mile North of Pahute Mesa Rd on Tippipah } \\
\text { Highway. The fire was } 3 \text { miles west of this location } \\
\text { ina canyon. Used ATVs to get to fire. }\end{array}$ \\
\hline $6 / 21 / 2001$ & 250.0 & 14 & Vehicle Exhaust & $\begin{array}{l}\text { Grass fire on Mid Valley Road, } 2 \text { miles south of } \\
\text { Mine Mtn (1-2 miles south of UXO Site Number } 6 \\
\text { N36 55' } 82 \text { " W116 09' 23"). Road Grid Coordinates: } \\
3655175 \mathrm{~N}, 1160847 \mathrm{~W} \text {; cause was determined to } \\
\text { be by hot vehicle exhaust system or by discarded } \\
\text { cigarette. ATVs were used to control the fire. }\end{array}$ \\
\hline $7 / 3 / 2001$ & 0.1 & 22 & Unknown & $\begin{array}{l}\text { Mile marker } 5 \text { west side of Highway } 95.20^{\prime} \text { x } 20^{\prime} \text { in } \\
\text { size. }\end{array}$ \\
\hline $7 / 4 / 2001$ & 1.0 & 22 & Lighning & $\begin{array}{l}\text { A couple of yuccas on both the east and west sides } \\
\text { of Mercury highway. Fire surpressed by rain. }\end{array}$ \\
\hline $7 / 3 / 2001$ & 150.0 & 18 & Lightning & $\begin{array}{l}\text { Grass fire approximately } 8 \text { miles south west of } \\
\text { Buckboard Mesa Road and Well } 8 \text { Road in an } \\
\text { unacessable area.. A large column of smoke could } \\
\text { be seen coming from a fire on Timber Peak. }\end{array}$ \\
\hline $7 / 5 / 2001$ & 80.0 & 16 & Lightning & $\begin{array}{l}\text { Brush and Juniper fire behind Area } 16 \text { Tunnel "A" in } \\
\text { rocky steep terrain. }\end{array}$ \\
\hline $8 / 9 / 2001$ & 0.1 & 18 & Lightning & $\begin{array}{l}2 \text { miles W. of Castle Rock, } 50^{\prime} \times 50^{\prime} . \text { In deep } \\
\text { ravene, extinguished by the rain. }\end{array}$ \\
\hline $9 / 3 / 2001$ & 0.1 & 6 & Lightning & $\begin{array}{l}\text { Two yucca trees on fire near Tippapah Hwy and } \\
\text { Mine Mountain Rd. }\end{array}$ \\
\hline $11 / 7 / 2002$ & 0.1 & 18 & Military Training & $\begin{array}{l}\text { Extinguished small spot fires (CTOS) at fire standby } \\
\text { before they became larger brush fires. }\end{array}$ \\
\hline $11 / 13 / 2002$ & 0.1 & 23 & Tracer & $\begin{array}{l}6^{\prime} \times 6^{\prime} \text { area about } 300 \text { yards on WSI shooting Range } \\
\text { D. The fire was caused by a tracer round from the } \\
\text { shooting range. About } 8 \text { yucca plants were burned. }\end{array}$ \\
\hline $11 / 5 / 2002$ & 0.1 & 19 & Military Training & $\begin{array}{l}50^{\prime} \times 50^{\prime} \text { area of small trees and bursh on Dead } \\
\text { Horse Flat Road. Crew escorted to area by Project } \\
400 \text { personne. }\end{array}$ \\
\hline $3 / 4 / 2002$ & 0.1 & 16 & Electric Short & $\begin{array}{l}10^{\prime} \times 10^{\prime} \text { area of brush started by electric short in } 2 \\
\text { inch line on ground. }\end{array}$ \\
\hline 6/1/2002 & 0.1 & 5 & Lightning & $\begin{array}{l}\text { Area 5, approximately } 11 / 4 \text { mile East of F-800, near } \\
\text { the edge of Frenchman Flats (off NTS?) }\end{array}$ \\
\hline 6/4/2002 & 15.0 & 20 & Unknown & $\begin{array}{l}\text { Fire-1 was in N.W. corner of Area } 20, \text { S. W. of } 20-1 \\
\text { Road. Fire in valley in large trees and heavy grass. } \\
\text { Fire } 1 .\end{array}$ \\
\hline 6/4/2002 & 10.0 & 20 & Unknown & $\begin{array}{l}\text { Fire- } 2 \text { was about } 3 \text { or } 4 \text { miles north of Fire- } 1 \text { by } \\
\text { Radar Site } 20 \mathrm{FK} 1 . \text { In a rock canyon with heavy } \\
\text { Timber. }\end{array}$ \\
\hline $8 / 16 / 2002$ & 303.0 & 12 & Unknown & $\begin{array}{l}\text { Near U12g Tunnel Complex. Blackbrush and pinyon } \\
\text { juniper vegetation type. Area was reseeded with a } \\
\text { mixture of native plant species at lower elevations } \\
\text { where accessabilty permitted. }\end{array}$ \\
\hline
\end{tabular}


THIS PAGE IS INTENTIONALLY LEFT BLANK 


\section{DISTRIBUTION}

U.S. Department of Energy,

National Nuclear Security Administration

Nevada Site Office

Technical Library

P.O. Box 98518, M/S 505

Las Vegas, NV 89193-8518

U.S. Department of Energy,

National Nuclear Security Administration

Nevada Site Office

Public Reading Facility

c/o Nuclear Testing Archive

P.O. Box 98521 , M/S 400

Las Vegas, NV 89193-8521

U.S. Department of Energy,

Office of Scientific and Technical Information

P.O. Box 62

Oak Ridge, TN 37831-0062

Manager, Northern Nevada FFACO

Public Reading Facility

c/o Nevada State Library \& Archives
1 copy (uncontrolled)

1 copy (uncontrolled)

1 electronic copy (uncontrolled)

1 electronic copy (uncontrolled) 